\title{
PRETORIA STUDENT LAW REVIEW (2019) 13
}

\author{
Pretoria Tydskrif vir Regstudente \\ Kgatišobaka ya Baithuti ba Molao ya Pretoria
}

Editor-in-chief:

Primrose Egnetor Ruvarashe Kurasha

Editors:

Thato Petrus Maruapula

Mzwandile Ngidi

Frieda Shifotoka 


\title{
(2019) 13 Pretoria Student Law Review
}

\begin{abstract}
Published by:
Pretoria University Law Press (PULP)

The Pretoria University Law Press (PULP) is a publisher, based in Africa, launched and managed by the Centre for Human Rights and the Faculty of Law, University of Pretoria, South Africa. PULP endeavours to publish and make available innovative, high-quality scholarly texts on law in Africa. PULP also publishes a series of collections of legal documents related to public law in Africa, as well as text books from African countries other than South Africa.
\end{abstract}

For more information on PULP, see www.pulp.up.ac.za

Printed and bound by:

Minit Print, Hatfield, Pretoria

\section{Cover:}

Design by Adebayo Okeowo

To submit articles, contact:

PULP

Faculty of Law

University of Pretoria

South Africa

0002

Tel: +27 124204948

Fax: +27 123625125

pulp@up.ac.za

www.pulp.up.ac.za

ISSN: 1998-0280

(ㄷ) 2019 


\section{TABLE OF CONTENTS}

Editors' note: Legacy

by Primrose Egnetor Ruvarashe Kurasha

Tribute vii

Note on contributions viii

Restoring electricity use with the spoliation remedy:

A critical comment on Eskom Holdings Soc Ltd v Masinda 1 by Gustav Muller

Prescription: The present interpretation of extinctive prescription and the acquisition of real rights by Celinhlanhla Magubane

To be black and alive: A study of the inherent racism in the tertiary education system in post-1994 South Africa by Chelsea L. Swanepoel

Through thick and thin: From the regulation of queerness to queer theory as decolonisation by DJ van Wyk

The easy way out? Constitutional avoidance and its impact on human right enforcement in Botswana by Kago K.Y. Boiki

Looking to literature for transformation by Kayla Thomas

A discussion of intellectual history, jurisprudential theories and feminism in the eradication of epistemic violence in South Africa by Kiasha Pilla

Abstract $v$ substantive-equality - A critical race theory analysis of 'hate speech' as considered in the SAHRC-Report on utterances made by Julius Malema by Kyle Grootboom

A critical race feminist reading of the South African property law

by Laetitia Makombe 
Should the flag fit, or must we acquit?

by Nicholas Herd

The impact of the 4th Industrial Revolution on the employment relationship and adaptive skills requirements

by Odirile Sepeng

The role of law and governance in advancing climate resilience and climate justice by Otitoola Olufolajimi

\section{Case note:}

Stepping in the right direction towards fully realising the constitutional promise of Section 29(1)(a) of the Constitution

Federation of Governing Bodies for South African Schools (FEDSAS) $v$ Member of the Executive Council for Education, Gauteng and Another 2016 (4) SA 546 (CC)

by Philile Shandu

The feminist agenda, a fall of hierarchal redress or an attempt to establishing an 'equal' society gone wrong: An internal critique to feminist theories by Simon Motshweni

Subaltern responses to epistemic violence; the legacy of colonialism

by Siwelile S. Mkhwanazi 


\section{EDITORS' NOTE: LEGACY}

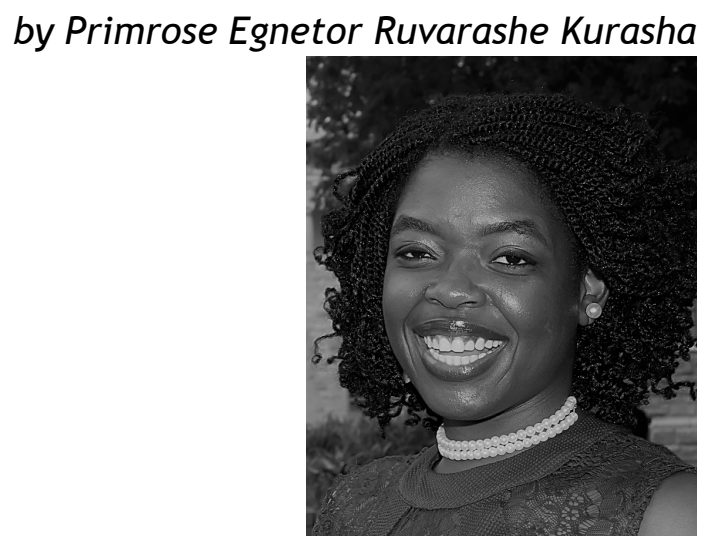

Honoured to be the first black Editor-in-Chief of the University of Pretoria's Law Review, an annual publication which is the pride of the best law faculty in Africa (according to the Times Higher Education World University Rankings), I proudly present to you the 2019 edition of the Pretoria Student Law Review (PSLR).

As I reflect on how the 17 year old me decided to one day become the President of the Law Review of 'whichever' tertiary institution I found myself at, after having been inspired by the first black Harvard Law Review President, President Barack Obama, who was appointed as such a year before my birth, I stand amazed at how inspiration and vision are literally a foretaste of a future God would have predestined for one, in this case mine.

With a vision to create a boldly outlined legacy for the PSLR, I spearheaded the setting up of systems that would last the lifespan of the PSLR, with my main focus as Editor-in-chief being on branding and operations. I am proud to announce that as the PSLR we now have our official email address; website; annual calendar; set dates for the publishing of our annual 'Call for Submissions' and annual 'Call for Applications' for the PSLR Editorial Board; official communication templates used for correspondence with our stakeholders namely, the Reviewers, the authors, the Editors and the public at large; sound disciplinary procedures and a significant social media presence. A consistent teammate in bringing this to fruition was Dr Gustav Muller, in his capacity as the PSLR Guardian.

Building on last year's legacy, for the first time in its history, the $P S L R$ used the same cover consecutively in different years, namely 2018 \& 2019. It is at this juncture that I would like to acknowledge 
and thank my predecessor, Mr Jürgen Zwecker, for the legacy he created for the $P S L R$, specifically in terms of its image and the foundation he laid for its branding. A legacy I have only been too glad to build upon and continue. To our photography genius Adebayo Okeowo, thank you very much for your exceptional cover art. Our conference calls between New York and Pretoria, with an emphasis on the different time zones which we managed remarkably well, yielded fruit.

Having thoroughly read each article and footnote in this edition, dotted every ' $i$ ' dotted and crossed every ' $t$ ', I cannot help but marvel at the culture of robust debate, research and relentless fact-finding cementing and holding together the identity of the University of Pretoria's Law faculty. The sharp legal minds it has moulded, may they forever be emblematic of the excellence, critical thinking and fruits of pluralism, cultural integration and transformation, which not only define the faculty but which will further entrench its spot on the world map. This PSLR edition also brags of articles from sister institutions and other African countries, as has been the case with previous editions.

It would be out of character for me not to acknowledge my exceptional team of Editors who committed to making this a quality publication, backing and forthing with the authors and reviewers. Thank you Thato Maruapula, Mzwandile Ngidi and Frieda Shifotoka! To the reviewers, your adjudication laid the foundation for this year's PSLR edition and we are grateful to you, especially for doing so gratuitously. To the authors, you have started your publishing career on a remarkable note. To Lizette Hermann and Elzet Hurter, your dedication to the PSLR for over a decade, has us as the Editorial Board and the Law Faculty forever indebted.

To the renowned philosopher and theologian hailing from Georgetown University and New York University, who introduced me to publishing, my dear father Prof Jemison Kurasha, ndinotenda Mukanya (thank you Dad, father of the clan). To my exceptional mentor and late mother, the first female Pro-Vice Chancellor and Vice Chancellor in Zimbabwe, a world renowned academic and diplomat par excellence, you were wise and diligent enough to build a legacy which has outlived you Prof Primrose Kurasha, all by the grace of God. My dear sister, best friend and Economist of note, Flora M.N. Kurasha, your knees keep me standing.

Dear reader, enjoy the read!

Primrose Egnetor Ruvarashe Kurasha Editor-in-Chief

2019 


\section{TRIBUTE}

This specific PSLR edition is a tribute to the former Dean of the Law Faculty of the University of Pretoria, Prof Andre Boraine.

For promoting the Pretoria Student Law Review (PSLR) so well, that it has been acknowledged by and nominated for the Yunus Mahomed Public Interest Law award in consecutive years, thank you Prof.

For presiding over our faculty in a manner so sound, that saw it becoming the best law faculty in Africa in 2018, according to the Times Higher Education World University Rankings, you also promoted the PSLR and enhanced its readership. Again, thank you Prof.

For being an exceptional Guardian of the $P S L R$, ever-supportive and more than willing to offer much needed truth, tough talk and solid guidance, thank you Prof Boraine. 


\section{NOTE ON CONTRIBUTIONS}

We invite all students to submit material for the eleventh edition of the Pretoria Student Law Review. We accept journal articles, case notes, commentary pieces, response articles or any other written material on legal topics. You may even consider converting your research memos or a dissertation chapter into an article.

Please visit our website at www.pslr.co.za for more information.

You may submit your contribution to:

pretoriastudentlawreview@gmail.com

Alternatively you may submit your contribution by hand at the office of the Dean of the Law Faculty:

Dean's Office

Faculty of Law

4th Floor

Law Building

University of Pretoria

Pretoria

0002 


\section{RESTORING ELECTRICITY USE WITH THE SPOLIATION REMEDY: A CRITICAL COMMENT ON ESKOM HOLDINGS SOC LTD V MASINDA}

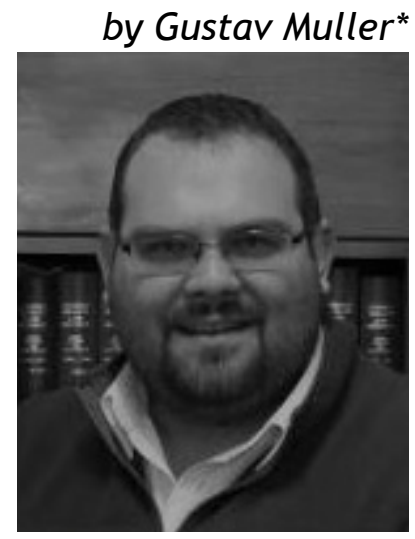

\section{Introduction}

In Eskom Holdings SOC Ltd $v$ Masinda' ('Masinda') teams from the appellant removed various illegal connections to the national electricity reticulation grid. The removal was animated by a concern for the well-being of those people living in homes with illegal connections and to prevent damage to their property as a result of these dangerous connections. ${ }^{2}$ While the exact reasons for the removal of the illegal connections were not clearly articulated in the appellant's submissions, it appears that the connections constituted an immediate danger to the public because the equipment were too small; it did not meet the prescribed quality standards; and it was not installed by an authorised contractor. ${ }^{3}$ The respondent argued that she used the electricity in her home by drawing supply through a prepaid meter and that this supply constituted an incident of her occupation. She successfully sought the restoration ante omnia of the electricity supply to her home in the Eastern Cape Division of the High Court, Mtatha. ${ }^{4}$ On appeal Leach JA reasoned that it could not have

* $\quad$ LLB LLD (Stellenbosch University), Diploma (Åbo Akademi). Senior Lecturer in the Department of Private Law, University of Pretoria. ORCID: 0000-0003-1254-6601.

12019 (5) SA 386 (SCA).

2 Masinda par 2.

3 Masinda par 3.

4 Masinda par 9. 
been the intention of the court $a$ quo to order the restoration ante omnia of a connection 'that was unlawful and a danger to the public.' Restoration ante omnia that 'complied with the necessary requirements of safety' would not only have required the appellant to do something more than restoring the property to its former state, ${ }^{5}$ but also extended the purpose of the spoliation remedy to include the 'reconstituted equivalent' 6 of the specified property. ${ }^{7}$ However, if the court $a$ quo intended the restoration ante omnia of an unlawful and dangerous electricity supply, ${ }^{8}$ the further difficulty would be that the order would be directing the appellant to 'commit an illegality' which itself would be sufficient for a court to refuse the spoliation remedy. ${ }^{9}$ Finally, Leach JA reasoned that the mere existence of an electricity reticulation supply in the respondent's home is insufficient to afford her a right that qualified as an incident of her occupation. ${ }^{10}$ He therefore upheld the appeal ${ }^{11}$ and dismissed the respondents 'terse' claim as 'misplaced' and 'insufficient'. ${ }^{12}$

In this article I provide a critical comment on the Masinda judgment. I seek to do so by providing a brief exposition of the importance of having access to and being able to stop unlawful interfere with your access to electricity in part 2. In part 3 I set out the requirements, features and application of the mandament van spolie. This is followed in part 4 with an analysis of the growing jurisprudence (comprising two high court judgments that predate democracy and two judgments from the Supreme Court of Appeal in the past decade) where the mandament van spolie was used to seek restoration ante omnia of electricity use.

\section{The importance of electricity from a human rights perspective}

In Government of the Republic of South Africa $v$ Grootboom ${ }^{13}$ (Grootboom), Yacoob J provided a nuanced exposition of the obligations that flow from section 26 of the Constitution. In his analysis the right of access to adequate housing entails 'more than bricks and mortar’. Importantly, this includes access to:

$5 \quad$ See Zinman v Miller 1956 (3) SA 8 (T).

6 Tswelopele Non-Profit Organisation v City of Tshwane Metropolitan Municipality 2007 (6) SA 511 (SCA) par 24. See also Ngomane $v$ City of Johannesburg Metropolitan Municipality [2019] 3 All SA 69 (SCA) par 18-20 and Rikhotso $v$ Northcliff Ceramics 1997 (1) SA 526 (W) at 535B-C.

7 Masinda par 10.

8 Masinda par 12.

9 Masinda par 13.

10 Masinda par 22

11 Masinda par 27.

12 Masinda par 24

132001 (1) SA 46 (CC). 
available land, appropriate services such as the provision of water and the removal of sewage and the financing of all of these, including the building of the house itself. For a person to have access to adequate housing all of these conditions need to be met: there must be land, there must be services, [and] there must be a dwelling. ${ }^{14}$

Yacoob J's description of what it means to have access to adequate housing in South Africa - in particular, services like electricity resembles $^{15}$ one of the characteristics that the United Nations Committee on Economic, Social and Cultural Rights ${ }^{16}$ ('CESCR') identified as being indicative of having access to housing for purposes of article $11(1)^{17}$ of the International Covenant on Economic, Social and Cultural Rights ${ }^{18}$ ('ICESCR'). Housing, according to the CESCR, will be considered adequate if it inter alia provides access to:

certain facilities essential for health, security, comfort and nutrition. All beneficiaries of the right to adequate housing should have sustainable access to natural and common resources, safe drinking water, energy for cooking, heating and lighting, sanitation and washing facilities, means of food storage, refuse disposal, site drainage and emergency services. ${ }^{19}$

Conceptualising access to services - like and electricity - as an integral part of the right of access to adequate housing reinforces Yacoob J's contextual approach to the interpretation of section 26 of the Constitution. ${ }^{20}$ On the one hand, the approach forges explicit textual links with section 32 of the Constitution. ${ }^{21}$ In doing so the

14 Grootboom par 35 (emphasis added).

15 Despite the 'significant' textual differences that Yacoob J enumerated in Grootboom par 28.

16 The committee consists of 18 experts with internationally recognised competence in the field of human rights who serve in their personal capacity for a renewable four year term. The primary task of the Committee is to assist the Economic and Social Council with its consideration of the reports that States Parties submit to the Secretary-General of the United Nations (article 16(2) of the ICSECR).

17 Article 11(1) of the ICESCR, which affords everyone the right to an adequate standard of living, reads:

'The States Parties to the Present Covenant recognize the right of everyone to an adequate standard of living for himself and his family, including adequate food, clothing and housing, and to the continuous improvement of living conditions. The States Parties will take appropriate steps to ensure the realization of this right, recognizing to this effect the essential importance of international cooperation based on free consent.'

18993 UNTS 3. The Covenant was adopted by the General Assembly of the United Nations on 16 December 1966 and came into force on 3 January 1976. As at 19 June 2019, the Covenant has been ratified by 169 countries. South Africa signed the Covenant on 3 October 1994 and ratified it on 15 January 2015.

19 CESCR General Comment 4: The right to adequate housing (Art 11(1)), UN Doc E/ C 1992/23 (1991) par 8(b).

20 Grootboom par 21.

21 Section 32(1) of the Constitution affords everyone 'the right of access to - (a) any information held by the state; and any information that is held by another person and that is required for the exercise or protection of any rights.' The Promotion of Access to Information Act 2 of 2000 was enacted to give effect to section 32(2) of the Constitution. See, in general, Currie I and De Waal J The Bill of Rights Handbook 6th ed (2013) chapter 30; Klaaren J and Penfold G 'Access to Information' in Woolman S, Bishop M and Brickhill J (eds) Constitutional Law of South Africa 2 nd ed, chapter 62. 
conceptualisation affirms the interrelated, interconnected and mutually supporting nature of all the rights in the Bill of Rights. ${ }^{22}$ On the other hand, the approach highlights the social and historical context against which the denial of access to electricity ${ }^{23}$ (including as a source of energy for cooking) ${ }^{24}$ should be interpreted.

The Constitution states that it is one of the objects of local government to ensure the provision of basic services to communities ${ }^{25}$ in an equitable and sustainable manner. ${ }^{26}$ The power to realise these basic services have been assigned to local governments in terms of two important statutes: ${ }^{27}$ the Housing Act 107 of $1997^{28}$ and the Local

22 See, in general, Liebenberg S Socio-economics rights: Adjudication under a transformative constitution (2010) 51-54 and the sources cited there.

23 White Paper par 3.1.4(c) estimated that $46.5 \%$ of all households did not have a link to the electricity supply grid in 1994. The latest statistics from Statistics South Africa indicate that the percentage of households in South Africa that are connected to the mains electricity supply increased by $7,7 \%$ (or 5.086 million households) from 76,7\% (or 8.586 million households) in 2002 to $84,4 \%$ (or 13.672 million households) in 2017. See Statistics South Africa Statistical Release P0318, General Household Survey 2017 (2019) 32.

24 The percentage of households in South Africa that use their connection to the mains electricity supply for cooking increased by $18,4 \%$ (or 5.858 million households) from 57,5\% (or 6.437 million households) in 2002 to 75,9\% (or 12.295 million households) in 2017. As a result there was a simultaneous decline in the percentage of households that use paraffin $(11,9 \%$ or 1.122 million households), wood $(11,6 \%$ or 0.878 million households) and coal $(2,6 \%$ or 0.271 million households). However, the increase in the percentage of people that use gas $(2 \%$ or 0.434 million households) for cooking over the same period is an interesting development. See Statistics South Africa Statistical Release P0318, General Household Survey 2017 (2019) 33.

25 Section 152(1)(b), read with section 153, of the Constitution. The range of basic municipal services that a municipality should provide includes, in terms of schedule $4 \mathrm{~B}$ of the Constitution, electricity and gas reticulation; municipal health services; municipal public transport; municipal public works; stormwater management systems in built-up areas; and water and sanitation services limited to potable water supply systems and domestic waste-water and sewage disposal systems. Schedule $5 B$ of the Constitution adds cleansing; local amenities; municipal parks and recreation; municipal roads; refuse removal, refuse dumps and solid waste disposal; and street lighting.

26 Section 155(4) of the Constitution.

27 Section 156(1) and (4) read with sections $155(6)$ and (7) of the Constitution. See Muller $\mathrm{G}$ and Liebenberg $\mathrm{S}$ 'Developing the law of joinder in the context and evictions of people from their homes' (2013) 29 SAJHR 554-570 559-565 for a brief overview of these statutes.

28 The long title of the Act states that the purpose of the Act is to facilitate sustainable housing development. Section 1 of the Act defines 'housing development' as 'the establishment and maintenance of habitable, stable and sustainable public and private residential environments to ensure viable households and communities in areas allowing convenient access to economic opportunities, and to health, educational and social amenities in which all citizens and permanent residents of the Republic will, on a progressive basis, have access to - (b) potable water, adequate sanitary facilities and domestic energy supply'. Section 9(1) of the Act imposes a peremptory obligation of local governments to '(a) ensure that - (iii) services in respect of water, sanitation, electricity, roads, stormwater drainage and transport are provided in a manner which is economically efficient' and '(g) provide bulk engineering services, and revenue generating services in so far as such services are not provided by specialist utility suppliers'. 
Government: Municipal Systems Act 32 of $2000 .^{29}$ The Constitution and these framework statutes create a 'special cluster of relationships' 30 that exist between individuals and the municipalities which are mandated to facilitate access to these services. However, despite the 'public law nature' 31 of these services, property law principles play a significant role in obtaining access to statutory utility rights $^{32}$ and protecting individuals from unlawful interferences with their use of these services.

\section{Quasi-possessio of incorporeals}

The spoliation remedy (or mandament van spolie) requires the spoliator to restore the applicant (spoliatus) to the position she was in prior to the dispossession. ${ }^{33}$ The nature of the spoliation remedy is to protect stable property relations from infringements in the context of unlawful dispossession. ${ }^{34}$ The foundational principle of the spoliation remedy is that control must be restored to the dispossessed party before all else (spoliatus ante omnia restituendus est). To that end the purpose of the spoliation remedy is to discourage self-help by restoring possession that was lost as a result of spoliation. ${ }^{35}$

29 The long title of the Act states that purpose of the Act is to enable local authorities to move progressively towards the social and economic upliftment of communities, and to ensure that these communities obtain universal access to abovementioned basic services. Section 1 of the Act defines 'basic municipal services' as 'a municipal service that is necessary to ensure an acceptable and reasonable quality of life and, if not provided, would endanger public health or safety or the environment.' Section 73(1)(c) of the Systems Act places a peremptory obligation of local governments to ensure that all residents of the community have access to at least the minimum level of basic municipal services. Section 73(2) states that these municipal services must: (a) be equitable and accessible; (b) be provided in a manner that is conducive to (i) the prudent, economic, efficient and effective use of available resources, and (ii) the improvement of standards of quality over time; (c) be financially sustainable; (d) be environmentally sustainable; and (e) be regularly reviewed with a view of upgrading, extending and improving the service.

30 Residents of Joe Slovo Community, Western Cape v Thubelisha Homes 2010 (3) SA 454 (CC) par 343.

31 Joseph $v$ City of Johannesburg 2010 (4) SA 55 (CC). In this case the electricityservice provider that is wholly-owned by the City of Johannesburg, City Power (Pty) Ltd, terminated the electricity supply to the applicants' homes because their landlord owed it a substantial amount of money. The Constitutional Court was asked to consider whether any legal relationship existed between the applicants and City Power, beyond the contractual relationship that existed between City Power and the landlord, and whether that relationship (between service provider and consumer) would entitle the applicants to procedura fairness in terms of s 3(2)(b) of the Promotion of Administrative Justice Act 3 of 2000 (PAJA).

32 In terms of the Water Services Act 107 of 1998; the National Water Act 36 of 1998 ; the Electricity Regulation Act 4 of 2006 and the Electronic Communications Act 36 of 2005.

33 Boggenpoel ZT Property Remedies (2017) 94.

34 Van der Walt AJ 'Squatting, spoliation orders and the new constitutional order' (1997) 60 THRHR 522-529 525.

35 Kleyn DG 'The protection of quasi-possession in South African law' in Descheemaeker E (ed) The consequences of possession (2014) 185-210 187. 
The spoliation remedy is characterised by the fact that it is an extraordinarily robust, speedy and temporary remedy. Its robustness flows from its singular purpose to effect ante omnia restoration of possession. ${ }^{36}$ To that end there are few requirements which the spoliatus should be able to satisfy on a balance of probabilities with relative ease. The onus then shifts to the respondent to raise a defence $^{37}$ against the operation of the remedy if the spoliatus is successful in proving the constituting requirements. Once these requirements have been established a court has no discretion to preclude the operation of the remedy based on the balance of convenience $^{38}$ to the parties or apparent injustice of restoring possession to the spoliatus. ${ }^{39}$ The remedy is speedy because it is instituted by way of motion procedure and usually takes the form of a special ex parte or urgent application proceeding. The speediness of the remedy is enhanced by the fact that the court may not consider the merits, including the wrongfulness and illegality of the control, during the proceedings. ${ }^{40}$ This characteristic makes the remedy particularly attractive and ensures that the restoration of possession ante omnia is effected 'without unnecessary delays.' 41 While the spoliation order is final, the restoration ante omnia also makes it provisional in nature ${ }^{42}$ because the merits of the dispute will be evaluated by a court in any subsequent petitory action (iudicium petitorium). ${ }^{43}$ The threat of the spoliation order serves as a warning to any person who can assert a real right in terms of a particular thing to rather take recourse to the courts of law and not to succumb to the allure of self-help. ${ }^{44}$

36 Boggenpoel ZT Property Remedies (2017) 98.

37 See Boggenpoel ZT Property Remedies (2017) 128-153 and Badenhorst PJ, Pienaar JM and Mostert H Silberberg and Schoeman's The Law of Property 5th (2006) 302 308. Taitz J 'spoliation proceedings and the "grubby-handed" possessor' (1981) 98 SALJ 36-41 indicates that there are a limited number of defences that can be raised against the spoliation remedy and argues that there is no reason why the list of defences should be expanded. However, Van der Walt AJ 'Defences in spoliation proceedings' (1985) 102 SALJ 172-180 argues that the developing spoliation jurisprudence may have opened up the possibility that other defences could be raised against the operation of the remedy.

38 Beukes v Crouse 1975 (4) SA 215 (NC) at 218 and Runsin Properties (Pty) Ltd v Ferreira 1982 (1) SA 658 (SE) at 670. However, in Parker v Mobil Oil of Southern Africa (Pty) Ltd 1979 (4) SA 250 (NC) the court refused to grant the remedy on the basis that restoration ante omnia would cause extreme hardship to the respondent and would in any event be of no use to the applicant.

39 Boggenpoel ZT Property Remedies (2017) 99-100.

40 See Ivanov v North West Gambling Board 2012 (6) SA 67 (SCA).

41 Boggenpoel ZT Property Remedies (2017) 100.

42 Boggenpoel ZT Property Remedies (2017) 98. Contrast Eskom v Nikelo [2018] ZAECMHC 48 (21 August 2018).

43 Kleyn DG 'The protection of quasi-possession in South African law' in Descheemaeker E (ed) The consequences of possession (2014) 185-210 187.

44 Muller G The impact of section 26 of the Constitution on the eviction of unlawful squatters in South African law (unpublished LLD dissertation, Stellenbosch University, 2011) 60-63 and Muller G 'The legal-historical context of urban forced evictions in South Africa' (2013) 19 Fundamina 367-396 386-387. 
To succeed with the spoliation remedy the applicant must prove that she was in peaceful and undisturbed possession of the property; and that she was unlawfully dispossessed. ${ }^{45}$ For purposes of the first requirement the applicant must prove that her possession was stable and enduring. Stated differently, the possession must have been sufficiently established so that the law may attach legal consequences to it. ${ }^{46}$ It is trite that possession requires the existence of both the factual control (corpus) over the property 47 and an outward manifestation of the appropriate mental attitude (animus) towards the property. ${ }^{48}$ The applicant must therefore have had effective control over the property ${ }^{49}$ coupled with the intention to draw a benefit from the thing by exercising physical control over it (animus sibi habendi). ${ }^{50}$ For purposes of the second requirement the applicant must prove two aspects. First, there must be some form of dispossession of the whole or part of the property. ${ }^{51}$ The dispossession must be of such a nature that the interference, whether 'substantial and serious' 52 or a 'mere disturbance', 53 affects the ability of the applicant to use the property. Second, the dispossession must furthermore be characterised by the fact that it was done 'forcibly or wrongfully' and without the consent of the applicant. ${ }^{54}$ The nonconsensual nature of the dispossession can additionally flow from the fact that the dispossession is possible in terms of the common law defence of counter spoliation; or because it is authorised by legislation ${ }^{55}$ or executed in terms of an order of court. ${ }^{56}$

45 Nino Bonino v De Lange 1906 TS 120 and Yeko $v$ Qana 1973 (4) SA 735 (A) at 739.

46 Ness $v$ Greef 1985 (4) SA 641 (C) at 647.

47 Badenhorst PJ, Pienaar JM and Mostert H Silberberg and Schoeman's The Law of Property 5ed (2006) 276-279; Sonnekus JC and Neels JL Sakereg Vonnisbundel 2de uitg (1994) 127-130; Van der Merwe CG Sakereg 2nd ed (1989) 97-103.

48 Badenhorst PJ, Pienaar JM and Mostert H Silberberg and Schoeman's The Law of Property 5ed (2006) 279-284; Sonnekus JC and Neels JL Sakereg Vonnisbundel 2de uitg (1994) 130-132; Van der Merwe CG Sakereg 2nd ed (1989) 103-107

49 CG van der Merwe 'Things' in LTC Harms \& JA Faris JA (eds) The Law of South Africa vol 27 (2nd ed 2014) par 108; Badenhorst PJ, Pienaar JM and Mostert H Silberberg and Schoeman's The Law of Property 5ed (2006) 295

50 Yeko v Qana 1973 (4) SA 735 (A) at 739.

51 Bennett Pringle (Pty) Ltd v Adelaide Municipality 1977 (1) SA 230 (E) at 233.

52 Burger $v$ Van Rooyen 1961 (1) SA 159 (0) at 160-161.

53 Pienaar v Matjhabeng Plaaslike Munisipaliteit [2012] ZAFSHC 213 (22 November 2012) par 11.

54 Nino Bonino v De Lange 1906 TS 120 at 122

55 In Erasmus v De Villiers Berrange NO [2013] ZAFSHC 149 (10 September 2013) the applicant challenged the lawfulness of a warrant to attach cows in terms of section 69(3) of the Insolvency Act 24 of 1936. In Elias Dunias t/a Colosseum Internet Lounde $v$ Minister of Safety and Security [2013] ZAKZNPHC 55 (17 October 2013) the applicant's cash, equipment and documents were seized for an alleged violation of the National Gambling Act 7 of 2004 and the KwaZuluNatal Gaming and Betting Act 8 of 2010.

56 Boggenpoel ZT Property Remedies (2017) 123. 
The application of the spoliation remedy to use rights is controversial $^{57}$ because their intangible nature makes it impossible to physically hold or control the objects of these incorporeal rights. The law therefore recognises the control of such objects through the notion of quasi-control. However, the spoliation remedy only protects the quasi-control of certain rights because it was never intended to have a 'catch-all' function to protect the quasi-control of all types of rights. ${ }^{58}$ If this were possible, litigants could rely on this remedy to enforce all personal rights (instead of specific performance in contract law), which would collapse the distinction between property law and the law of contract. ${ }^{59}$ For purposes of this extended application of the spoliation remedy the central question is therefore always whether quasi-control of a particular right enjoys protection under this remedy. Finally, it must be noted that what the spoliation remedy protects here is not the rights themselves, but rather the factual status quo of exercising these rights. ${ }^{60}$

From case law it is clear that the spoliation remedy protects the quasi-control of two types of rights, namely servitudal rights and incidents of occupation. ${ }^{61}$ While it is not always possible to draw a sharp distinction between the two rights, the former concern rights which are servitudal in nature while the latter pertain to rights which are incidental to (or a component of) the control of a tangible object. ${ }^{62}$ Kleyn observes that the jurisprudence in this area of the law in practice arise because the rights exercised by the spoliatus is in doubt or the spoliatus allegedly defaulted on the payment of contractual fees for the provision of these services. ${ }^{63}$ Another instance, which is closely linked to the latter, is that the disconnection of these services is an overt attempt by the spoliator to constructively evict the spoliatus without a court order.

57 See Telkom SA Ltd v Xsinet (Pty) Ltd 2003 (5) SA 309 (SCA) par 9 and DG Kleyn 'The protection of quasi-possession in South African law' in E Descheemaeker (ed) The consequences of possession (2014) 193-194.

58 Zulu $\vee$ Minister of Works, KwaZulu, and Others 1992 (1) SA 181 (D) 188 and Firstrand Ltd t/a Rand Mercant Bank v Scholtz NO 2008 (2) SA 503 (SCA) par 13 (footnotes omitted).

59 DG Kleyn 'The protection of quasi-possession in South African law' in $\mathrm{E}$ Descheemaeker (ed) The consequences of possession (2014) 185-210 195; JC Sonnekus \& JL Neels Sakereg Vonnisbundel (2nd ed 1994) $168 \mathrm{ff}$.

60 Shoprite Checkers Ltd v Pangbourne Properties Ltd 1994 (1) SA 616 (W).

61 ZT Boggenpoel Property Remedies (2017) 107; CG van der Merwe 'Things' in LTC Harms \& JA Faris JA (eds) The Law of South Africa vol 27 (2nd ed 2014) paras 97-98 ff; DG Kleyn 'The protection of quasi-possession in South African law' in E Descheemaeker (ed) The consequences of possession (2014) $198 \mathrm{ff}$.

62 ZT Boggenpoel Property Remedies (2017) 113-114; CG van der Merwe 'Things' in LTC Harms \& JA Faris JA (eds) The Law of South Africa vol 27 (2nd ed 2014) par 99.

63 DG Kleyn 'The protection of quasi-possession in South African law' in E Descheemaeker (ed) The consequences of possession (2014) 185-210 188. 


\section{Analysis}

\section{Earlier case law on electricity}

In Froman v Herbmore Timber \& Hardware 64 ('Froman') the applicant purchased a sectional title unit from the respondent and took occupation of the unit before the transfer was registered. ${ }^{65}$ Their agreement made provision for the payment of the following costs by the applicant until the transfer was registered: occupational rent, a monthly levy, and the water and electricity usage. ${ }^{66}$ Approximately five weeks after the agreement was concluded the respondent cancelled the contract because the applicant allegedly defaulted on the payment of the water and electricity usage. ${ }^{67}$ The applicant disputed that he defaulted on the payment and subsequently also refused to vacate the unit. The respondent then disconnected the water supply and electricity reticulation to the unit. When the applicant reconnected these services the respondent retaliated by not only severing the connection to the services completely, but also removed the front door of the unit and an internal sliding door. ${ }^{68}$ The court, approvingly citing previous case law $^{69}$ and old authorities, ${ }^{70}$ held that the disconnection of the water supply and electricity reticulation 'amounted to an unlawful deprivation of applicant's possession of a right. ${ }^{71}$ O'Donovan $\mathrm{J}$ also held that the respondent took the law into its own hands by removing the doors in an attempt to execute a constructive eviction. ${ }^{72}$ The court ordered the respondent to reconnect the services and to the reinstall the doors so as to restore the status quo ante. ${ }^{73}$

In Naidoo $v$ Moodley ${ }^{74}$ ('Naidoo') the appellant leased the first floor of a double storey residence to the respondent. The respondent was under an obligation to pay the lease amount and a flat rate for electricity usage every month. ${ }^{75}$ The appellant terminated the lease a year later, but the respondent refused to vacate the residence. Protracted negotiations ensued and a settlement was concluded that would see the respondent vacate the residence four months after the

Froman at $610 \mathrm{~A}-\mathrm{B}$.

Froman at 610B.

Froman at 610C-D.

Froman at 610E-F.

69 Nino Bonino v De Lange 1906 TS 120; Painter v Strauss 1951 (3) SA 307 (0); and Nisenbaum v Express Buildings (Pty) Ltd 1953 (1) SA 246 (W).

70 Wassenaar Prac Jud chapter 14 article 1 ('eenige goederen of gerechtigheden') and Voet 43.16.7.

71 Froman at 611D.

72 Froman at 611E.

73 Froman at $611 \mathrm{~F}$.

741982 (4) SA 82 (T).

75 Naidoo at 83D. 
lease was terminated. ${ }^{76}$ The appellant finally disconnected the electricity supply to the first floor a month after the respondent again refused to vacate the residence. ${ }^{77}$ While the appellant denied that the respondent was unlawfully deprived of his right to use the electricity in the residence, he conceded that the disconnection was effected deliberately by switching off the supply on the distribution box on the ground floor of the residence. ${ }^{78}$ The appellant argued that the respondent could not frame a claim for specific performance in terms of a contract - the restoration of the electricity supply - under the guise of the spoliation remedy. However, Eloff $\mathrm{J}$ reasoned that 'the use of electricity was an incident of occupation' which the respondent had possession of through the occupation of the first floor of the residence and 'by using its appurtenances, including electrical installations and power. ${ }^{79^{\circ}}$ As a result, he held that it was 'immaterial' whether the contractual right to use electricity was severable from the lease. The court placed significant emphasis on the fact that the respondent used the electricity until the appellant disconnected the reticulation to the first floor. In dismissing the appeal the court held that the appellant's deliberate disconnection of the electricity supply 'substantially interfered' with the respondent's occupation of the first floor of the residence. ${ }^{80}$

In Rademan $v$ Moqhaka Municipality 81 ('Rademan') the appellant and other members of the Moqhaka Ratepayers and Residents Association withheld payments of their municipal taxes and levies with the hope that the local government would attend to their concerns about poor service delivery. The appellant continued to pay for the supply of water and sanitation, electricity reticulation and refuse removal services. In response the local government disconnected the supply of electricity reticulation to her home in August 2009 in an attempt to enforce payment of her outstanding municipal account in the amount of nearly R3000. The appellant successfully launched an urgent application for the restoration of the electricity reticulation supply to her home in the Magistrates' Court in Kroonstad, but this was subsequently overturned by the Free State Division of the High Court, Bloemfontein on appeal. ${ }^{82}$ It is in an appeal against this latter judgment that the appellant asked the Supreme Court of Appeal to decide whether the local government lawfully disconnected the electricity reticulation supply to her home without a court order. The appellant argued that the disconnection amounted to spoliation and that the she was entitled to the restoration ante 
omnia of the electricity reticulation supply to her home. ${ }^{83}$ However, the court agreed with the respondent's argument that the Local Government: Municipal Systems Act 32 of 2000 permits it to: levy and collect municipal rates and taxes; ${ }^{84}$ enforce payment if any account is in arrears; ${ }^{85}$ and that the regulatory framework did not require an order of court to effect the disconnection. ${ }^{86}$ The court held that it is 'both unrealistic and untenable' for municipalities to approach a court each time a user defaults on her municipal account in order to obtain an order directing it to terminate the services. ${ }^{87}$ The credit control and debt collection regulatory framework that flows from the Systems Act and the Bylaws of respective municipalities must enable it to 'collect all moneys that are due and payable to them in the most cost-effective manner.' 88 The court cited with approval the dicta of Yacoob $\mathrm{J}$ in Mkontwana where it was emphasised that:

municipalities are obliged to provide water and electricity and that it is therefore important for unpaid municipal debt to be reduced by all legitimate means. It bears repeating that the purpose is laudable, has the potential to encourage regular payments of consumption charges, contributes to the effective discharge by municipalities of their obligations and encourages owners of property to fulfil their civic responsibility. ${ }^{89}$

83 Rademan par 4. The court dismissed the alternative argument that the local government failed to afford her 14 days' notice similar to that which the Constitutional Court granted the tenants in Joseph because the facts were distinguishable in that the tenants did not have a contract with the local government.

84 Rademan paras 5, 7-9. Section 229(1) of the Constitution read with section 5(1)(g) which affords members of local government the right 'to have access to municipal services' provided that they comply with the obligation 'to pay promptly service fees, surcharges on fees, rates on property and other taxes, levies and duties imposed by the municipality' in terms of section $5(2)(b)$ of the Systems Act.

85 Rademan paras 5, 10-14. Section 96 of the Systems Act states that '[a] municipality - (a) must collect all money that is due and payable to it, subject to this Act and any other applicable legislation; and (b) for this purpose, must adopt, maintain and implement a credit control and debt collection policy which is consistent with its rates and tariff policies and complies with the provisions of this Act.' Section 97(1) of the Systems Act adds that a credit and debt collection policy must provide for "' $(\mathrm{g})$ termination of services or the restriction of the provision of services when payments are in arrears.' The Credit Control and Debt Collection Bylaws (14 May 2004) of Moqhaka City was adopted to give effect to the Systems Act and section 25 of the Bylaws empowers the local government to '(1) ... restrict or disconnect the supply of water and electricity or discontinue any other service to any premises whenever a user of any service - (a) [f]ails to make full payment on the due date or fails to make acceptable arrangements for the repayments of any amount for services, rates or taxes.' See also section 102(1)(a) of the Systems Act which allows for the consolidation of separate municipal accounts and section 25(3) of the Bylaw which adds that the right to restrict, disconnect or terminate any service as a result of non-payment will prevail notwithstanding the fact that payment may have been made in respect of some other service.

86 Rademan par 5 and 21.

87 Rademan par 16.

88 Rademan par 17.

89 Mkontwana par 52. 
This civic responsibility preclude residents from cherry-picking the accounts they would like to pay in a strategic endeavour to frustrate the optimal governance of a municipality and prevent it from fulfilling its wide-ranging constitutional obligations that must be funded by the overall revenue collected from all residents. ${ }^{90}$ Furthermore, the court situated the resident's obligation to pay for all municipal services within a carefully-grafted supply chain which includes the respective municipalities and other suppliers like, in this particular matter, Eskom. ${ }^{91}$ The court, rather dismissively, remarked that the prevalence of demonstrations about poor service delivery ${ }^{92}$ was largely attributable to the fact that residents fail to appreciate that services can only be delivered by the respective municipalities if residents pay all their municipal accounts. ${ }^{93}$ The court emphasised this point with reference to Pretoria City Council v Walker ${ }^{94}$ where the Constitutional Court stated that:

Local government is as important a tier of public administration as any. It has to continue functioning for the common good; it, however, cannot do so efficiently and effectively if every person who has a grievance about the conduct of a public official or a governmental structure were to take the law into his or her own hands or resort to self-help by withholding payment for services rendered. That conduct carries with it the potential for chaos and anarchy and can therefore not be appropriate.

In dismissing the appeal, 95 the court resolved not to determine whether the spoliation remedy was applicable to situations where personal use rights to municipal services flow from legislation or from a contractual relationship. ${ }^{96}$

Naidoo and Froman were arguably decided correctly in that both judgments found a mere interference with the factual use of electricity reticulation to be sufficient for the spoliation remedy to find application. ${ }^{97}$ Furthermore, neither judgments attached any significance to the relative right to use electricity reticulation ${ }^{98}$ or possessory interests (a lawful occupiers in Froman and an unlawful

90 Rademan par 19.

91 Rademan par 20.

92 See Muller $G$ The impact of section 26 of the Constitution on the eviction of unlawful squatters in South African law (unpublished LLD dissertation, Stellenbosch University, 2011) 15.

93 Rademan par 20.

941998 (2) SA 363 (CC).

95 Rademan par 23.

96 Rademan par 22.

97 See Nienaber v Stuckey 1946 AD 1049 at 1059 and Burger v Van Rooyen 1961 (1) SA 159 (0) at 160G-161A. See also Van der Walt AJ 'Nog eens Naidoo v Moodley - ' $n$ repliek' (1984) 47 THRHR 429-439 430.

98 Compare Coetzee v Coetzee 1982 (1) SA 933 (C) at 935D and Parker v Mobil Oil of South Africa 1979 (4) SA 250 (NC) at 255C-E where the courts held that this was an important consideration. 
occupier in Naidoo) of the applicants. ${ }^{99}$ Froman and Naidoo must be distinguished from Rademan and Masinda in that an organ of state 100 (a municipality and a state-owned enterprise respectively) effected the disconnection. Yet, it is questionable whether the journey that the Supreme Court of Appeal chose to arrive at this destination is the most appropriate one in terms of a single legal system. ${ }^{101}$

The court's reasoning in Rademan is flawless but for the finding that the spoliation was lawful in terms of the regulatory framework that the Systems Act creates. The law requires strict adherence to the authorising provisions in a statute that permits dispossession ${ }^{102}$ and 'full compliance with all the prescribed formalities and procedures to ensure that the deprivation does not amount to unlawful spoliation.' 103 Any statute that authorises a person (natural or juristic) to take the law into their own hands will be interpreted restrictively. ${ }^{104}$ In this regard it is noteworthy that both section 97(1)(g) of the Systems Act and section 25(1) of the Bylaws make provision for the restriction of electricity supply as an alternative to the disconnection or termination of the service. As a result Rademan should arguably have been decided along a similar line as City of Cape Town v Strümpher ${ }^{105}$ where the Supreme Court of Appeal reinstated water services to a caravan park because the discontinuation was not 'fair and equitable' in terms of section 4(3)(a) of the WSA. In this alternative arc the court should have acknowledged that the applicant was in peaceful and undisturbed possession of the electricity reticulation supply to her home. Additionally, the court should have allowed the operation of the spoliation on the basis that

99 See Mankowitz v Loewenthal 1982 (3) SA 758 (A); Yeko v Qana 1973 (4) SA 735 (A); Ntai v Vereeniging Town Council 1953 (4) SA 579 (A); Dönges v Dadoo 1950 (2) SA 321 (A); Van Eck and Van Rensburg v Etna Stores 1947 (2) SA 984 (A); and Nino Bonino v De Lange 1906 TS 120. See also Van der Walt AJ 'Naidoo v Moodley 1982 4 SA 82 (T) - mandament van spolie' (1983) 46 THRHR 237-240 239.

100 Section 239 of the Constitution defines an 'organ of state' as '(a) any department of state or administration in the national, provincial or local sphere of government; or (b) any other functionary or institution - (i) exercising a power or performing a function in terms of the Constitution or a provincial constitution; or (ii) exercising a public power or performing a public function in terms of any legislation, but does not include a court or a judicial officer.'

101 I borrow this metaphor from Boggenpoel ZT 'Can the journey affect the destination? A single system of law approach to property remedies' (2016) 32 SAJHR 71-86.

102 Boggenpoel ZT Property Remedies (2017) 123 and Tsegeya $v$ Minister of Police 2018 JDR 1377 (ECM).

103 Boggenpoel ZT Property Remedies (2017) 128 and Impala Water Users Association $v$ Lourens NO and Others 2008 (2) SA 495 (SCA) par 9. On this requirement, see the conflicting decisions in Van Rhyn and Others NNO V Fleurbaix Farm (Pty) Ltd 2013 (5) SA 521 (WCC) and Knox and Another $v$ Second Lifestyle Properties (Pty) Ltd and Another (A28/2011) [2012] ZAGPPHC 223 (11 October 2012) and the discussion by Boggenpoel ZT Property Remedies (2017) 125-127.

104 See, for instance, Midvaal Local Municipality v Meyerton Golf Club 2014 JDR 2243 (GJ); African Billboard Advertising (Pty) Ltd $\vee$ North and South Central Local Councils, Durban 2004 (3) SA 223 (N).

1052012 (4) SA 207 (SCA). 
the spoliation was unlawful. In this context a restrictive interpretation of the authorising provisions would have preferred, in the first instance, the restriction of the electricity reticulation supply to the applicant's home.

\section{Masinda}

Masinda is problematic for a few reasons. The first relates to the obiter remarks by Leach JA regarding to operation of the spoliation order that the court $a$ quo granted the respondent. He is probably correct that it could not have been the intention of the court a quo to order the restoration ante omnia of a connection 'that was unlawful and a danger to the public.' However, Zinman $v$ Miller ${ }^{106}$ provides ample authority for the proposition that the spoliator can be ordered to do something more than restoring the property to its former state which could easily include restoring possession in such a manner that it complied with the necessary requirements of safety. Furthermore, the court's reasoning that the purpose of the spoliation remedy does not include the restoration of a 'reconstituted equivalent' of the specified property probably does not hold water either. Blecher ${ }^{107}$ and Van der Walt ${ }^{108}$ persuasively argues with reference to Fredericks $\checkmark$ Stellenbosch Divisional Council ${ }^{109}$ that the spoliation remedy could be applied outside of its traditional restorative framework in the specific circumstances where the property was destroyed on purpose to frustrate a restoration order and where the destroyed property was fungible. ${ }^{110}$ It is likely that the appellant's teams removed the illegal connections deliberately to frustrate the operation of the spoliation remedy in the interests of the owners' safety and well-being. However, an argument can be made that the electrical installations

1061956 (3) SA 8 (T). In this case the appellant, an electrical engineer, removed the main panel from the electrical meter chamber and cut the electrical wiring so that there was no flow of electrical current in the respondent's, the owner of the property, house. The court a quo found that it had no jurisdiction to decide the case in terms of section 46(2)(c)(ii) of the Magistrate's Courts Act 32 of 1944. On appeal Rumpff $\mathrm{J}$ found that section 46(2)(c)(ii) of the Act did not limit the jurisdiction of the magistrate to grant the extraordinary remedies of a temporary nature provided for in section 30(1) of the Act. Section 30(1) provides that '[s]ubject to the limits of jurisdiction prescribed by this Act, the Court may grant against persons and things orders for arrest tanquam suspectus de fuga, attachments, interdicts and mandamenten van spolie.' Rumpff J (at 12) confirmed that the purpose of the mandament van spolie was to restore possession ante omnia and therefore could include an order for 'something to be done in addition to the mere putting of the spoliated back in possession of the thing spoliated.' In this case the mandament van spolie required the replacement of the main panel and the reconnection of the electrical wires.

107 Blecher MD 'Spoliation and the demolition of legal rights' (1978) 97 SALJ 8-16.

108 Van der Walt AJ 'Developing the law on unlawful squatting and spoliation' (2008) 125 SALJ 24-36; Van der Walt AJ 'Nog eens Naidoo v Moodley - 'n repliek' (1984) 47 THRHR 429-439 and Van der Walt AJ 'Naidoo v Moodley: Mandament van spolie' (1983) 46 THRHR 237-240.

1091977 (3) SA 113 (C). 
do not have any unique characteristics that would preclude its replacement with generic substitutes of equal weight, measure and number.

Second, in holding that the supply of electricity itself is not an incident of occupation, the court perpetuates the line of case law, which began with Telkom SA Ltd $v$ Xsinet (Pty) Ltd, ${ }^{111}$ where the Supreme Court of Appeal created confusion as to how exactly the protection of quasi-control works. In Masinda the court continues this line of reasoning as follows:

In order to justify a spoliation order the right must be of such a nature that it vests in the person in possession of the property as an incident of their possession. Rights bestowed by servitude, registration or statute are obvious examples of this. On the other hand, rights that flow from a contractual nexus between the parties are insufficient as they are purely personal and a spoliation order, in effect, would amount to an order of specific performance in proceedings in which a respondent is precluded from disproving the merits of the applicant's claim for possession. ${ }^{112}$

In considering the rights of the applicant during the possessory suit the court negates the speedy nature of the remedy which precludes a consideration of the merits.

Third, contrary to what the court held in Masinda, the applicant's claim was not "terse". In his judgment Leach JA refers to the fact that the applicant used purchased electricity using a card with a number that corresponded with the number of the electricity meter; that a vendor supplied her with a voucher that contained a unique code on it; that she punched the code into the pre-paid electricity meter which then registered a credit; and that she then drew electricity from the national grid through the meter into her home. ${ }^{113}$ This 'outward manifestation,114 of her factual use of electricity presents incontrovertible evidence in support of her claim that she had quasipossession of the electricity reticulation supply to her home. To this extent her claim was appropriately framed and abundantly evidenced.

Finally, Masinda could arguably have been decided along a different line of reasoning. In this alternative arc the court should have acknowledged that the applicant was in peaceful and

110 Fungible things belong to a certain generic class of things that can be replaced by any other similar thing. They do not have any characteristics that make them so unique as to be considered irreplaceable. In trade, fungible things are often referred to in terms of weight, measure or number. Non-fungible things are considered irreplaceable because they have unique characteristics or value. See Van der Merwe CG Sakereg (2nd ed 1989) 43; Van der Merwe CG \& De Waal MJ The Law of Things and Servitudes (1993) 22.

1112003 (5) SA 309 (SCA).

112 Masinda par 22.

113 Masinda paras 5 and 23.

114 Bon Quelle (Edms) Bpk v Munisipaliteit van Otavi 1989 (1) SA 508 (A) at 514I. 
undisturbed possession of the electricity reticulation supply to her home. However, the court should have precluded the operation of the spoliation remedy with reference to the defence that it is impossible to restore illegal possession ${ }^{115}$ of electricity reticulation to the applicant's home. The court noted that the application of section 25 of the ERA was in dispute, but it could have reasoned that the installations were not made by a licensee ${ }^{116}$ that operated under the peremptory conditions of ensuring compliance with 'health, safety and environmental standards and requirements.'117

\section{Conclusion}

The preceding analysis reveals that it is possible to protect access to services in terms of another distinct property principle - namely, protecting quasi-possession of use rights as incidents of occupation with the spoliation remedy. The applicant will have to show the she used the electricity reticulation in her residence. This outward manifestation of the factual use of these services should allow the applicant to appropriately frame a claim that the spoliator interfered with or took over control of her right. In Masinda the Supreme Court of Appeal decided to perpetuate the flawed line of reasoning that it adopted in Telkom. In this article I showed why this reasoning is problematic and proposed an alternative arc along which the court should rather develop its jurisprudence on the application of the mandament van spolie for purposes of electricity. In doing so the court can reaffirm, as the high courts did in Froman and Naidoo, the robust and speedy nature of the spoliation remedy and its ability to swiftly and effectively restore the applicant to the factual position she was in before the dispossession. However, the relief will only be temporary and she should use the time to formulate a claim based a servitudal right or a statutory use right.

115 See Boggenpoel ZT Property Remedies (2017) 142-149 and the sources cited there for an authoritative analysis of this defence.

116 Section 7(1)(a) of the ERA.

117 Section 14(1)(s), read with section 14(1)(n), of the ERA. 


\section{PRESCRIPTION: THE PRESENT INTERPRETATION OF EXTINCTIVE PRESCRIPTION AND THE ACQUISITION OF REAL RIGHTS}

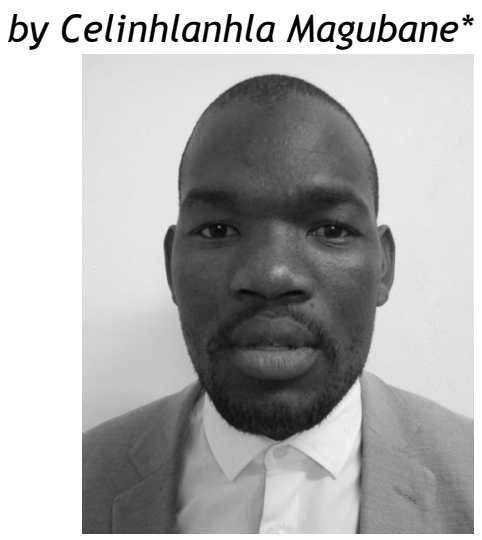

\section{Introduction}

The Prescription Act provides that a debt can prescribe or rather 'expire' and further that one can acquire ownership through prescription. ${ }^{1}$ Prescription in simple terms refers to old debt which occurs when it is no longer an obligation for a debtor to pay off their debt. One of the original methods of acquiring real rights is by the passage of time, and other various types of obligations may be rendered unenforceable by the effluxion of time.

\section{The running of prescription}

MM Loubser stated in his book that, 'the main objective of extinctive prescription is to create legal certainty and finality in the relationship between the parties after the lapse of a period of time'. 2 The emphasis is on the protection of the defendant against a stale claim that has existed for such a long time. ${ }^{3}$ "It becomes unfair to require the defendant to defend himself against it, solely because the

Chairperson - Black Lawyers Association Student Chapter, Unisa, Durban.

68 of 1969.

M Loubser Extinctive Prescription (1996) 33.

As above. 
claimant is responsible for enforcing his right timeously and must therefore suffer the consequences of failure in this regard. 4

Prescription in South African law is governed by the Prescription Act and it consists of four chapters. It is also important to note that not all debt prescribes in a period of three years, as some of the types of debt are likely to take an extended period of time to prescribe. These are discussed below.

The Constitutional Court in the matter between Makate $v$ Vodacom (Pty) Ltd gave debt a narrow meaning providing that, a debt means only an obligation to pay money, deliver goods, or render services. ${ }^{5}$ The Constitutional Court also confirmed that only a personal right and not a real right can give rise to a debt which can be extinguished through prescription. ${ }^{6}$ Real rights are primarily concerned with the relationship between a person and a thing meanwhile personal rights are concerned with a relationship between two persons. ${ }^{7}$

Furthermore, it should also be noted that in simple terms, a debt can be anything that is owed or that is due such as money, goods or services that a debtor is under an obligation to pay or to render to a creditor. ${ }^{8}$ In Absa Bank Limited $v$ Keet, the Court established that a debt is that which is owed or due, or anything which one person is under obligation to pay or render to another and whatever is due from any obligation. ${ }^{9}$

A debt becomes due when it is capable of being claimed, i.e. when it is time for the debtor to perform. In most instances the parties agree on a date the debtor is required to render his/her performance. However, if the parties had not agreed on a certain date or specific time upon entering into the contract, a debt will become due as soon as it arises. In the Supreme Court of Appeal (SCA) case between Standard bank of SA Ltd v Miracle Mile Investments 67 (Pty) Ltd and another, the Court had to decide on the question concerning when a debt becomes due in terms of the Prescription Act, specifically, in relation to instalment agreements which contain an acceleration clause. ${ }^{10}$ The SCA had to ascertain whether a debt becomes due at the time when the debtor breaches the agreement, or only once the creditor elects to enforce its rights under the acceleration clause in the facility agreement (rendering the entire amount outstanding due

Loubser (n 2) 32.

[2016] ZACC 13.

As above.

Absa Bank Limited $v$ Keet [2015] 4 All SA 1 (SCA) at p 2.

Cf Erasmus $v$ Grunow en 'n Ander 1978 (4) SA 233, at 254E.

[2015] JOL 33298 (SCA) p 3.

10 The Standard Bank of South Africa Ltd v Miracle Mile Investments 67 (Pty) Ltd \& another case $187 / 215$ at para 2 . 
at that time). ${ }^{11}$ The timing of prescription depends on the wording of the particular acceleration clause. The SCA held that if a creditor elects not to enforce his rights to accelerate the full outstanding amount, the creditor is entitled to wait until all the individual instalments become due before instituting action. ${ }^{12}$ The court however warned that in such circumstances, a creditor runs the risk of prescription having 'taken effect in respect of earlier instalments'. ${ }^{13}$

In terms of section 12(1) of the Prescription Act, the debt begins to run on the day that the debt becomes due and enforceable or the date by which the creditor could reasonably have become aware of the breach. ${ }^{14}$ For example, if $\mathrm{X}$ built a house for $\mathrm{Y}$ in 2018 at a price of R1 Million Rand and on the 31st of January 2020 the roof of the house starts leaking as a result of destructive construction (positive malperformance) by $\mathbf{X}$, prescription in terms of the law starts running on the 31st of January 2020 as this is the date the owner of the house would have become aware of the defect, which constitutes a breach.

It is also important to note that the owner $\mathrm{Y}$ must be aware of the defect on the roof before the date of prescription. Furthermore, section 12(3) of the Prescription Act provides that a debt shall not be deemed to be due until the creditor has knowledge of the identity of the debtor and of the facts from which the debt arises, unless the creditor could have acquired such knowledge by exercising reasonable care. ${ }^{15}$ In the Law of Contract in South Africa Text book, Hutchison states that;

A person who is not aware that a delict has been committed against him/her or that a claim based on unjustified enrichment has been raised in his/her favour, is hereby protected against the commencement of prescription, provided that his/her lack of knowledge is not due to the unreasonable conduct of the creditor. ${ }^{16}$

Moreover, a debt can be considered as prescribed if it has met certain pre-requisites which include inter alia, failure to acknowledge the existing debt, no payment having been made for that particular debt for a certain period of time and/or the failure to summon one in respect of the debt within a certain period of time as per the prerequisite of such debt.

Additionally, not all debt prescribes within a period of three years as aforementioned. The following types of debts are likely to take an extended period of time to prescribe;

11 As above.

12 The Miracle Mile Investments 67 case (n 10) at para 15.

13 The Miracle Mile Investments 67 case (n 10) at paras 15-16.

1468 of 1969.

15 As above.

16 D Hutchison and others The Law of Contract in South Africa (2017) 493. 
(a) Debt secured by a mortgage bond prescribes after 30 years; ${ }^{17}$

(b) Judgment debt also prescribes after 30 years; ${ }^{18}$

(c) Taxation imposed by law; ${ }^{19}$

(d) Debt arising from mining activities in relation to the State also prescribes after 30 years; ${ }^{20}$

(e) Debt owed to the State arising from a loan, sale, or lease of land prescribes after 15 years; ${ }^{21}$

(f) All the other debts prescribe after 3 years. ${ }^{22}$

The general rule applies to all kind of aforementioned debts, that in terms of the said Act, prescription starts running as soon as a debt is due. 23

Lastly, in the recent SCA case of Fluxmans Incorporated $v$ Levenson, the Respondent Levenson had concluded a contingency fee agreement with the Appellant, a firm of Attorneys called Fluxmans Incorporated. ${ }^{24}$ The Appellant deducted the contingency fee when Levenson's claim was successfully settled. Five years after payment, the Respondent became aware of the fact that the agreement was void as it was not in writing and had not been signed by the parties as required by the Contingency Fees Act 66 of $1997 .{ }^{25}$ The Appellant defended the claim on the basis that it had prescribed. ${ }^{26}$ On appeal, the Judge President of the SCA held that the agreement was void as it did not comply with Section 12(3) of Prescription Act, which provides that a debt must not be deemed to be due until the creditor has knowledge of the identity of the debtor and the facts from which the debts arises. ${ }^{27}$

\section{Instances when prescription is delayed}

Section 13 of the Prescription Act deals with the delay of prescription. ${ }^{28}$ According to this provision, the period of prescription would be considered to have delayed if one of the following restrictions applies:

(a) The creditor is a minor or insane or is a under curatorship or is prevented by superior force, including any law or any order of Court from interrupting the running of prescription;

17 Sec 11(a)(i) of the Prescription Act 68 of 1969 as amended.

18 Sec 11 (a) (ii) of the Prescription Act 68 of 1969 as amended.

19 Sec 11(a)(iii) of the Prescription Act 68 of 1969 as amended.

20 Sec 11(a)(iv) of the Prescription Act 68 of 1969 as amended.

21 Sec 11(b) of the Prescription Act 68 of 1969 as amended.

22 Sec 11(d) of the Prescription Act 68 of 1969 as amended.

$23 \mathrm{Sec} 12$ of the Prescription Act 68 of 1969 as amended.

24 [2017] 1 All SA 313 (SCA).

25 Fluxmans Incorporated v Levenson [2017] 1 All SA 313 (SCA) at para 2-3.

26 As above.

27 Fluxmans Incorporated case (n 25) at para 6.

2868 of 1969. 
(b) The debtor is outside the Republic ;

(c) The creditor and debtor are married to each other;

(d) The creditor is a juristic person and the debtor is a member of the governing body of a juristic person;

(e) The debt is the object of a claim filed against the state of a debtor who is deceased or against the insolvent estate of the debtor or against a company in liquidation or against an application under the Agricultural Credit Act;

(f) The creditor or the debtor is deceased and an executor of the state in question has not yet been appointed.

In light of the above, it is also important to note that prescription does not commence to run against ${ }^{29}$ a person while he remains non compos mentis as a result of injuries. ${ }^{30}$ Should the impediment cease to exist, the creditor may institute action until one year after the impediment has ceased to exist. ${ }^{31}$ Furthermore, should the impediment cease to exist more than a year before the end of the normal prescription period, the impediment does not affect the running of prescription. ${ }^{32}$ This is because the creditor had one year to institute action after cessation of the impediment. ${ }^{33}$

In Malcom v Premier, Western Cape Government NO, a matter that dealt with the delay of prescription in terms of section 13(1) of the Prescription Act in respect of a minor, the Constitutional Court presided over a claim of damages sought by the Appellant from the Respondent. ${ }^{34}$ The Appellant was admitted to a State hospital for cancer treatment but whilst he was in hospital undergoing treatment, there was an outbreak of Hepatitis B at the hospital and in October 1994 he was diagnosed with that disease. Alleging that he had contracted it due to negligence on the part of the hospital and its staff, the Appellant sought damages from the Respondent.

His claim was met with a special plea of prescription. ${ }^{35}$ The plea of prescription was resisted on the basis that when the claim arose, the Appellant had until one year after he turned 21 to institute the action and that was not affected by the statutory amendment to the age of majority. Reliance was placed on the broad principle that statutory changes are presumed not to prejudice acquired rights and in terms of the Prescription Act, as he commenced the proceedings

29 Sec 13 of the Prescription Act 68 of 1969.

$30 \mathrm{Sec} 13(1)(\mathrm{a})$ of the Prescription Act 68 of 1969. See also the Fluxmans Incorporated case.

31 Hutchison (n 16) 488.

32 As above.

33 As above.

34 [2014] 2 All SA 251 (SCA).

35 Malcom v Premier, Western Cape Government NO [2014] 2 All SA 251 (SCA) at para 1. 
within one year of 21 , it was contended that his claim had not prescribed. ${ }^{36}$

The issue in the aforementioned matter arose from a change in the law relating to the age of majority that occurred after the Appellant had been infected with Hepatitis B. At that time the age of majority was 21 years in terms of the Age of Majority Act. ${ }^{37}$ However, the age of majority was repealed by section 17 of the Children's Act, which came into operation on the 1st of July $2007 .{ }^{38}$ In terms of the law, Prescription does not run against a minor. Moreover, it is of paramount importance to note that the word 'major' sometimes is used to refer to a specific age or to a person who enjoys full legal capacity.

Prescription can also be delayed on the basis that the debt is the object of a claim filed against a company in liquidation. In the Western Cape Division matter between Van Deventer and Another $v$ Nedbank Ltd, the Respondent had originally sued the Appellants on the basis of the latter having signed as surety for a close corporation which had fallen into debt with the Respondent. ${ }^{39}$ The Appellant argued that the claim had prescribed because the summons had been issued more than three years after the relevant debt had arisen. ${ }^{40}$ The Court held that the purpose of Section 13(1)(g) of the Prescription Act was clear in circumstances where insolvency legislation contained a specifically tailored non-litigious procedure for establishing claims against insolvent parties. ${ }^{41}$ The Court further held that it was undesirable as a matter of policy that creditors should have to engage in a parallel process of litigation so as to prevent their claims from prescribing, and, likewise, for those administering the insolvency, to be put through the expense of investigating and defending litigation claims which could be established without controversy through specified procedures. ${ }^{42}$

\section{Interruption of prescription}

In terms of the law, once the debt has prescribed you are not legally obligated to pay the amount owed. The interruption of prescription happens by an express acknowledgment in writing of liability on the part of the debtor or in respect of the service on the debtor of any process whereby the creditor claims payment of the debt. This process is also known as the judicial interruption process. In simple

The Malcom case (n 35) at para 1-2.

57 of 1972.

38 of 2005.

2016 (3) SA 622 (WCC) at 4.

Van Deventer and Another $v$ Nedbank Ltd 2016 (3) SA 622 (WCC) at 8.

The Van Deventer case (n 40) at 8.

42 The Van Deventer case at (n 40) 10-11. 
terms, the onus rests on the debt collector or an attorney to recover monies owed to them within a specified period and not delay recovery, such that it accumulates massive amounts of interest and costs.

As aforementioned, prescription is interrupted by an admission of indebtedness or by institution of judicial process whereby, the creditor institutes legal action to recover the debt. For example, if $\mathbf{X}$ owes $Y$ an amount of R20 000, which was due to be paid $Y$ on the 1st of January 2015 and $X$ failed to pay such amount to $Y$, and $Y$ did not take any action to enforce the debt, in terms of the Prescription Act the debt will prescribe after 3 years as on the 31st of December 2018. However, if $X$ admits that he owes $Y$ an amount of R20 000 on the 31st December 2018, prescription is interrupted and starts afresh. The debt will therefore only prescribe on the 31st of December 2021.

It is therefore imperative to also highlight that one of the mechanisms of interruption of prescription is by an acknowledgment of debt. The period of prescription begins to run de novo, unless the acknowledgment of debt is accompanied by an extension in writing on the day upon which the debt becomes due.

In the law of contract, the authors state clearly that 'a partial acknowledgement of liability interrupts prescription with respect to the debt as whole and that in order to interrupt prescription, the acknowledgment must be made by the debtor or by her authorized agent, and only to the creditor or agent.' 43

On the other hand, judicial interruption is effected by services of the summons on the debtor whereby a creditor claims payment of the debt. Judicial interruption of prescription is conditional upon the success of the attempt to enforce the debt. In order to prevent situations of abuse, the Prescription Act states that interruption by means of process served on the debtor shall lapse if creditor does not obtain final judgment in terms of the process or if a judgment obtained is set aside or abandoned. Furthermore, an effective interruption of prescription in terms of Section 15(1) of the Prescription Act, causes a new period of prescription to commence on the day on which the judgment becomes executable.

However, in the 2016 judgment of KLD Residential CC v Empire Earth Investment 17 (Pty) Ltd, the Court held that, when 'without' prejudice, offer of settlement does not interrupt prescription. In this matter the Plaintiff (KLD Residential CC) sued the Defendant (Empire Earth Investment) for commission earned after selling certain erven in a development project and transferring ownership to buyers. ${ }^{44}$ The commission was earned between October 2008 and November 2009 
when the transfer took place. The Plaintiff issued summons claiming commission in 2013, which is a period that was more than three years after the last commission was earned. Evidently, the claim had prescribed in terms of the Prescription Act. However, the Plaintiff alleged that the running of prescription had been interrupted when, in July of 2011, the Defendant's Attorneys, wrote a letter to the Plaintiff Attorneys acknowledging that, after taking into account certain deductions, the Plaintiff was entitled to a certain amount in respect of which a cheque was attached. ${ }^{45}$ Justice Rogers held that the acknowledgment of debt, and the offer of settlement made to the Plaintiff in a 'without prejudice' offer, did not interrupt prescription. ${ }^{46}$

This shows that in many exceptional circumstances where one thought prescription would run, it in fact does not. In the following recently decided case in the Gauteng Division, Pretoria, in the matter between De Klerk $v$ Ferreira and Others, the parties were equal members of close corporation Plaantsaam and shareholders in a company called Benjo. ${ }^{47}$ When they fell out, De Klerk sought orders to compel Ferreira to transfer his membership interest in Plaantsaam and shares in Banjo to him, against payment of fair and reasonable value. ${ }^{48}$

In his replication De Klerk pleaded that the debt arose out of a partnership relationship and that the partnership was only dissolved during $2015 .^{49}$ It was stated by the Court that there was a delay in the prescription as provided by the provisions of Section 13(1)(d) of the Prescription Act, which provides that if the creditor and debtors are partners and the debt which arose out of the partnership. ${ }^{50}$ The Court held that the period of prescription would be completed before or within a year of the dissolution of the partnership. ${ }^{51}$ Furthermore, it held that the period of prescription would not and cannot be completed before a year has elapsed after the dissolution of the partnership. ${ }^{52}$ In the consideration, Justice Murphy held that prescription was interrupted and that the debt had not prescribed when the summons was issued. ${ }^{53}$ He proceeded to dismiss the special plea of prescription. 54

In respect to the above submissions it is therefore of paramount importance to note that Courts have no authority to raise prescription 
particularly where parties have not raised it in their pleadings. This is governed by Section 17 of the Prescription Act, which clearly states that:-

(a) A Court shall not of its own motion take notice of prescription,

(b) A party to litigation, who invokes prescription, shall do so in the relevant document filed on record in the proceedings; provided that a Court may allow prescription to be raised at any stage of the proceedings. ${ }^{55}$

This was also confirmed in the Constitutional Court matter between Njoji v MEC, Department of Welfare, Eastern, where a disability grant of which the Applicant (Njonji) had been a recipient for just under ten years was stopped without a reason. ${ }^{56}$ The Applicant had requested to re-apply for the grant and her application succeeded, but her claim for pay back led to the present protracted proceedings. The Respondent raised a contention that the Applicant's claim had prescribed. ${ }^{57}$ The Court held that the Prescription objection was not properly raised by the Respondent except in a belated and invalid manner. ${ }^{58}$ The Court is prohibited, in terms of the Prescription Act, from considering the point mero motu. ${ }^{59}$ The stated that in light of the mero motu, it cannot on its own take notice of prescription. ${ }^{60}$ The Court further stated that presuming that prescription did apply, prescription would begin to run only once the decision was set aside by a Court or disavowed by the decision maker. ${ }^{61}$

In terms of the law, Prescription can also be applied in respect of acquisition of movable and immovable property. A person shall, by prescription, become the owner of a thing which he has possessed openly and as if he were the owner thereof, for an uninterrupted period of thirty years. ${ }^{62}$ Such period which, together with any periods for which such thing was so possessed in title, constitutes an uninterrupted period of thirty years. ${ }^{63}$

In the Supreme Court of Appeal matter dealing with the ownership of a thing, in the matter between Absa Bank Limited $v$ Keet, the Court found the merit in the argument that a claim for a vindicatory claim (claim based on ownership of a thing) cannot be described as a debt. ${ }^{64}$ Meaning therefore, that such a claim does not prescribe after 3 years as the debt, instead it prescribes after a period of thirty years uninterrupted.

5568 of 1969.

56 [2008] JOL 21573 (CC).

57 The Njoji case (n 56) at 2.

58 The Njoji case (n 56) at 1.

59 Sec 17 of the Prescription Act 68 of 1967.

60 The Njoji case $(\mathrm{n} 56)$ at 10.

61 The Njoji case (n 56) at 1.

62 Sec 6 of the Prescription Act 68 of 1969.

63 As above.

64 [2015] JOL 33298 (SCA). 


\section{Conclusion}

It therefore is important to note that prescription cannot be applied to achieve unjust results. Prescription cannot be applied in the acquisition of a thing (property) by means of fraud, and one cannot commit a debt with the intent of relying on prescription. That would defeat the purpose of the law. When interpreting prescription one should always uphold the need to strike a balance between the need to have a cutoff point beyond which a person who has a claim to pursue against another may not do so after the lapse of a certain period of time, if he/she failed to act diligently and to ensure fairness in those matters in which a rigid application of prescription legislation would lead to unfair or rather unjust results. 


\section{TO BE BLACK AND ALIVE: A STUDY OF THE INHERENT RACISM IN THE TERTIARY EDUCATION SYSTEM IN POST-1994 SOUTH AFRICA}

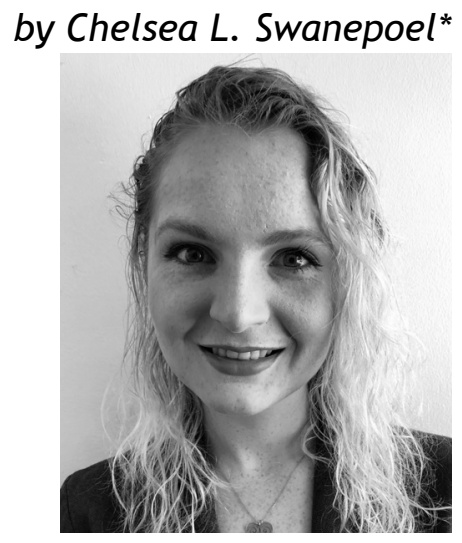

\section{Introduction}

The second decade of the 21st century has seen an increase in pressure on tertiary institutions across the globe to dramatically transform. This call has, to a large extent, been spearheaded by the Fees and Rhodes Must Fall Movements that began in South Africa in 2015, however, decolonial thought and African resistance to colonialism has been present since the birth of colonialism itself. ${ }^{1}$ Initially, the Rhodes Must Fall movement called for the removal of a statue of the imperialist slave owner, Cecil John Rhodes, and the 'uncritical memory of his legacy' with it, but this movement soon developed into cross-country protests of colonial bias, racism, and black exclusion in university settings. ${ }^{2}$ Similar calls for the

* Third year BA Law student majoring in English with a passion for the role of language and literature in daily life. In conducting research for this paper, I came across the spoken word poem by Crystal Valentine and Aaliyah Jihad titled: 'To be black and woman and alive' which comments on the paradoxical existence of black people and in particular, black women in society. This comment on identity and its application in a post-colonial university setting inspired this paper and holds true to its focus.

1 TK Ranuga 'Frantz Fanon and black consciousness in Azania (South Africa)' (1986) 47(3) Phylon at 186. See also B Kwoba, R Chantiluke \& A Nkopo. 'Rhodes must fall in Oxford' in Rhodes must fall: the struggle to decolonise the racist heart of empire (2018) 3.

2 Kwoba, Chantiluke \& Nkopo (n 2) 3. 
transformation of curricula were heard at Oxford in which the residual colonial legacies left by Rhodes and his contemporaries were labelled as the root cause of epistemic injustice in academia and were called to be removed. ${ }^{3}$

Since this movement, academics have, to a certain extent, had a consciousness of the need for the inclusion of both African and feminist thought across various faculties. At the University of Pretoria, Critical Race and Gender Theory have been adopted as a part of an elective module in the LLB program, the English department has started to include African texts from a first-year level, and the first black female doctor of Philosophy, Dr Mpho Tshivhase, has been employed as a lecturer of morality and ethics. ${ }^{4}$ Universities across South Africa have also undertaken the process of renaming spaces to be better represent the various cultures of the student body, as well as reviewing language policies. ${ }^{5}$ Despite these attempts at transformation, many have argued that their effect on the substantive decolonisation of South African academia has been merely superficial and that the ingrained and systematic racism and Eurocentrism of the university system has failed to be radically addressed. ${ }^{6}$

While many argue that science, academia and the law should be logical, objective and neutral, there are various debates surrounding first, whether such an objective is possible and second whether it is desirable. ${ }^{7}$ Historically, one can see that academics largely reflect upon the values of the society in which they operate and, in doing so, manifest a particular bias and prejudice precluding thought from being neutral. In Western academics, this bias is categorised as both racial and Christian in the construction of an image of the rest of the globe as a distinct 'other' in need of 'civilization'. ${ }^{8}$ Not only were scientific theories dismissed on the grounds of contradicting the Christian Bible, but they have also been fabricated or twisted into theories of pseudoscientific biology to justify racism and white supremacy. ${ }^{9}$ Though, for the most part, this mode of thought has been

3 Kwoba, Chantiluke \& Nkopo (n 2) 4.

4 JSM Modiri 'The grey line in-between the rainbow: (Re)thinking and (re)talking critical race theory in post-apartheid legal and social discourse' (2011) 26 South African Public Law at 178.

5 University of the Free State v Afriforum and Another 2018 (2) SA 185 (CC) para 3.

6 Modiri (n 4) 177-178.

7 VY Mudimbe Power and otherness in the invention of Africa: gnosis, philosophy and the order of knowledge. (1988) 20-21.

8 Horton, R 'Chapter 12' in African philosophy: A classical approach P English and KM Klumba (eds) (Prentice Hall: New Jersey 1996) 197-199. See also K Wiredu 'Conceptual decolonization as an imperative in contemporary African philosophy: Some personal reflections' (2002) 36 Rue Descartes, at 56.

9 N Eltringham, “'Invaders who have stolen the country': The Hamitic hypothesis, race and the Rwandan genocide,' (2006) 12(4) Journal for the Study of Race, Nation and Culture at 426. 
criticised in academic cultures, one cannot deny that their legacies remain, and that black inferiority is undeniably assumed by many.

Recently, examples of this phenomenon emerged with the publishing of two racist and stereotypical articles by two separate historically white universities in the Western Cape. Both articles focused on the 'mental capabilities' of people of colour with one paper, which had been completed by a professor of research, setting out to prove that 'higher IQ's' were a contributory factor in preventing certain West African populations from falling victim to slavery. ${ }^{10}$ While the other paper, completed by students and passed through the university's Ethics board, attempted to offer 'evidence' proving that coloured women have lower mental capabilities due to biological factors such as 'smaller head size.' These reports have been denounced by various members of the academic community for being based on stereotypes, skewed data, and biased assumptions that have been long refuted. ${ }^{11}$ However, the fact that they gained support from senior members in the university system, or that ethical committees did not question the absurdity of their thesis, is proof that this longheld colonial bias has not yet fallen.

This existence of scientific racism in a contemporary society, let alone contemporary or modern-day academia, is both vexing and puzzling to many however, further refuting the claims made by these papers is not the concern of this paper. I also do not aim to prove the existence of African thought and philosophy as I believe this is obvious. I do aim, however, to explore the epistemological violence against black people in academia and demonstrate how the assumption of European superiority contributes to that narrative. Through this paper, I aim to disprove the claim that knowledge, academic thought and societal discourse are neutral and objective, as well as explore links between transformation of the university system, the teaching of law and society in general. I argue that the constitution has failed at achieving a 'free, equal and unified' South Africa despite its objectives, and that the examination of the law with a critical approach of its racially charged aspects will offer some insight into addressing deep colonial biases. ${ }^{12}$ This will be done through examining the various arguments surrounding Eurocentrism and white supremacy in academia, society and the law. ${ }^{13}$

10 Z Dano Cape Argus, 'Stellenbosch study on coloured women 'draws on colonial stereotypes' 29 April 2019 https://www.iol.co.za/capeargus/news/stellenboschstudy-on-coloured-women-draws-on-colonial-stereotypes-2216623 (accessed 29 April 2019). See also N Daniels Cape Times, 'UCT prof resigns after slavery study' 16 May 2019 https://www.iol.co.za/capetimes/news/uct-prof-resignsafter-slavery-study-23318441 (accessed 18 May 2019).

11 Wiredu (n 8) 56.

12 Sec 1 of the Constitution of the Republic of South Africa, 1996.

13 J Modiri 'The colour of law, power and knowledge' (2012) 28 SAJHR at 406. 


\section{The colonial construction of a black identity}

African thought has not only been ignored for much of history but also had its existence denied. To colonial scholars, the ability to record history or the existence of the concept of a history at all in South Africa was deemed not to exist before European arrival in $1652 .^{14}$ Furthermore, colonial scholarship was characterised by copious scientific and anthropological studies set out to prove that African people did not possess the tools necessary for academic thought of substance. African languages were considered either absent altogether or, at least, at too 'primitive' a level to be of academic significance. This systematic denial of thought and academia has not only painted a vision of Africa as the 'Dark Continent' in need of European intervention and enlightenment, but it also sets out to prove that African people exist as 'sub-human' beings. ${ }^{15}$

Though mostly known as a leading figure in Euro-American philosophy, Kant set out to prove such a theory in his various anthropological and geographical studies. He argued that each person from each race is born with a level of capability to think rationally and that African people, though possessing the capability to learn certain skills in what he calls 'training,' do not possess the capabilities to do so. Kant also makes the assertion that the act of being human is directly related to the possession of rationality and philosophical thought necessary to actualise one's existence under law. In this way, not only does Kant deny the possibility of existence of African thought, but he also denies the existence of an original system of justice in Africa under which African people could exist. In this way, Kant denies African people the humanity reserved for Europeans, as well as the legitimacy of African law and morality. ${ }^{16}$

Though Kant's understanding of race has been denounced as both blatantly racist and inaccurate, it has not been completely severed from educational institutions today. White supremacy is not only left unchallenged by many, but a significant amount of effort is put into proving it. Bell notes how various studies over the years have set out to prove that some biological or scientific factor presupposes white superiority, with the immediate dismissal or denial of the contrary despite conclusive data. ${ }^{17}$ Whether racism is displayed in as blatant a setting as the basis of poverty and slavery apologist doctrines adopted by the recent studies from the Western Cape, or in the subtle

14 S Biko I write what $i$ like: A selection of his writings (1978). 76.

15 Mudimbe (n 7) 20-21.

16 EC Eze 'The Colour of Reason: The idea of “Race” in Kant's Anthropology,' in Philosophy from Africa: a text with readings (2nd ed) (eds) PH Coetzee and APJ Roux (2002) 349 \& 438.

17 D Bell 'Who's afraid of critical race theory?' (1995) University of Illinois Law Review at 899. 
treatments of black colleagues and students noted by Bell, the assumption that the identity of 'the African' is synonymous with that of inferiority, continues to plague academia. This demonstrates the residual assault of colonial subjugation on the possibility of an African academic identity.

Wiredu argues that in order to ask the question of whether African philosophy exists, one would have to approach it from a prejudiced standpoint. ${ }^{18}$ He demonstrates that, in order for one to question something's existence, one would have to consider the possibility that it does not exist, which in this case, would be the absurd possibility that African people are incapable of philosophical thought. ${ }^{19}$ While this mode of thought would question the existence of rationality and understanding of black people necessary to consider one's own affairs, it also mimics Kant's argument that black people are subhuman in comparison to white civilisation. The denial of African philosophy in this way, is a denial of African humanity that served as support for the justification of slavery and suppression of black people for centuries. 20

To a large extent, this assault on African epistemology was this basis of the thinking that colonialists used to dismiss any form of government, religion or philosophy as 'pagan' superstition or 'primitive' barbarism. ${ }^{21}$ This allowed the justification of colonial patriarchal rule in which black people were seen as incapable of running their own governments and required colonial rule. ${ }^{22}$ It allowed the economic quests of the scramble for land in Africa to be obscured by seemingly noble quests of Christianisation and, in turn, 'civilization'. ${ }^{23}$ In order for this model to be successful even after the recognition of African religions and societal structures, one would need to reject the very possibility of African philosophical and scientific thought of being of equal significance to Euro-American academia. ${ }^{24}$ This is still a pattern that is observed in Western academic circles today, which not only proves the existence of deep colonial biases but also the self-defeating model of decolonialisation that has been adopted. ${ }^{25}$

Ramose argues that, not only does this exclusion of African scientific and philosophical thought from educational circles, which is

18 K Wiredu 'What can philosophy do for Africa?' in Philosophy and an African culture K Wiredu (ed) (1980) 54.

19 Wiredu (n 18) 53. See also MB Ramose 'Discourse on Africa' in Philosophy from Africa: a text with readings (2nd ed) Coetzee, PH and Roux, APJ (eds) (2002) 4.

20 Ramose (n 19) 4.

21 Ranuga (n 1) 188.

22 KR White 2009. 'Scourge of racism: Genocide in Rwanda,' Journal of Black Studies (2009) 39(3) 473. See also Mudimbe (n 7) 20-21.

23 Mudimbe (n 7) 21.

24 Wiredu (n 18) 57.

25 Ramose (n 19) 5. 
based on illogical and unsound grounds, defeat the very nature of education as a whole, however, it also contributes to a paradoxical cycle that 'de-liberates' knowledge while aiming to transform it. ${ }^{26}$ Moridiri similarly notes this paradox in the advancement of the 1996 South African Constitution and that the supposed inferior nature of African thought is, to a certain extent, identifiable in jurisprudential practice. Though South Africa has, to a large extent, turned to the law as a tool to obtain transformation, topics of justice, morality and race are though not only isolated to a single, optional module, often fail to consider African thought surrounding these concepts. ${ }^{27}$ Wiredu's assessment of the contemporary educational climate echoes this observation in that, even when African philosophy is considered, it is drastically appropriated to legitimise existing euro-Christian assumptions. This focus on one set of possible answers to the achievement of justice perpetuates the colonial cycle of silencing black thought, as well as automatically assuming African inferiority.

Ramose argues that though efforts to decolonise have, on face value, removed the usurpation of the right of African people to speak for themselves, concepts of racial identity and justice are still intricately linked and cannot be ignored. ${ }^{28}$ Biko notes that the continued exclusion of African thought not only entrenches the colonisation of the mind and self-depreciation of people of colour, but that it pushes society further from the achievement of substantive justice. ${ }^{29}$ This demonstrates how the active exclusion of black thought from society is a significant factor in a system of selflegitimising illegitimate assumptions based on racist preconceptions. However, it also proves that the academic landscape is not neutral, despite the fact that race is understood to be social rather than scientific. ${ }^{30}$ One can also argue that the existence of this paradox is a manifestation of an inherently racist society that has not been defeated by the inclusion of rights-based legislation such as the Constitution.

\section{A critical approach to race and education}

Approaching the law and Constitution from the perspective of a critique is a characteristic of Critical Legal scholarship. This jurisprudential approach acknowledges that the law is constructed and used as a tool to preserve power relations that exist within the society, as well as the fact that it is, by its very nature, both political and ideological. ${ }^{31}$ Alongside the Gender Theory and Queer Theory,

Ramose (n 19) 6.

Modiri (n 5) 178.

Ramose (n 19) 6. See also Biko (n 14) 75.

Biko (n 14) 75.

30 B Hepple Equality: The new legal framework (2011) 36. 
the Critical Race Theory can be seen to mimic these acknowledgments of the charged nature of law. ${ }^{32}$ Be that as it may, the Critical Race theory places an increased emphasis on the economic and class divisions based on race that are present and perpetuated in society. Critical Race theorists critique this racist nature of the law and argue that this inherent racism is a reflection of the society in which it operates. They further argue that ignoring this property of the law plays a substantial role in the continued suppression of black people.

Jurisprudential scholars who adopt the Critical Race theory as a lens often argue that the law cannot and should not be studied in isolation. ${ }^{33}$ Many legal scholars are criticised for the continued attempt to distinguish 'pure' law from philosophical debates of justice and ethics. ${ }^{34}$ Failure to do so has been argued to result in the development of a lack of understanding of the moral implications that that law contains and a mechanical and unqualified application of the law. ${ }^{35}$ As many of these laws have been inherited from colonial and apartheid structures, many argue that this accounts for the lack of substantive change in society in post-1994 South Africa. It is for this reason that Critical Race theorists reject a restricted approach to jurisprudence and legal education and instead, encourage the law to be contextualised in its historic, political and moral contexts. ${ }^{36}$

Bell notes that inherited from its roots in the Critical Legal Studies movement, there exists both a commitment to 'radical critique of the law' at the basis of Critical Race theory, as well as an ultimate agenda of the reconstruction of the law and society in a manner that achieves the emancipation of black people. ${ }^{37}$ Though this ultimate goal is reminiscent of Civil Rights scholarship, Bell notes that Critical Race theorists dismiss claims regarding the redemptive power of rights legislation such as the Civil Rights Act. ${ }^{38} \mathrm{He}$ argues that, though the vision promised by rights legislation is one welcomed by many critical race scholars, their existence often results in the 'illusion' of equality rather than a qualitative attempt at justice owing to the non-racial structure often employed by rights legislation. ${ }^{39}$

Modiri harshly criticises the colour-blind approach to transformation often adopted by white liberals. ${ }^{40}$ This approach, also criticised by Biko, has been argued to contribute to a superficial

31 Modiri (n 5) 180.

32 J Modiri, "Towards a "post"-apartheid critical race jurisprudence: Divining our racial themes' (2012) 27 SAPL at 246.

33 D Bell (n 17) 899.

34 C Douzinas \& A Gearey Critical jurisprudence: The political philosophy of justice (2005) 5.

35 Douzinas \& Gearey (n 34) 7.

36 Douzinas \& Gearey (n 34) 3. See also Modiri (n 13) 412; Bell (n 17) 899.

37 Bell (n 17) 899.

38 Bell (n 17) 899. See also Sec 804 of the Civil Rights Act of 1964.

39 Bell (n 17) 900.

40 Biko (n 14) 69. 
transformation in which black people are, though liberated in theory, forced to enter a society that is structured to subjugate them rather than construct a new one. ${ }^{41}$ In his assessment of the constitution as a failed restorative document, Modiri recognises the extent to which a mechanical operation of blanket equality has contributed to this failure. ${ }^{42} \mathrm{He}$ argues that colonial law and structures of colonialapartheid actively sought to disempower and delegitimise the existence of African law in society in order for white economic gain. However, he also notes that these dynamics are still evident in the fact that even after the near three-decade long enactment of a values-based constitution, the juxtaposition of white privilege and black suffering is still noted in South African society. ${ }^{43}$ In this way, a mere mechanical application of the constitution to South African society has not undone the inequalities of the past but merely obscured black oppression.

Modiri further argues that the constitution, aside from ignoring past oppression, actively seeks to continue the inequality between black and white people. ${ }^{44}$ He notes the various constitutional mechanisms that prevent the radical distribution of property and the lack of access to resources faced by black people today yet ironically, such opportunities are given freely to white people. ${ }^{45}$ Furthermore, when considering concepts of justice and equality, the constitution does, to a large extent, focus solely on western models of justice and ownership with little to no consideration of African approaches to these concepts. Though the concept of Ubuntu has been recognised as integral to the theory of Transformative Constitutionalism, its use, application and understanding is paradoxical when juxtaposed with the strictly Roman and western interpretations of section 25.46 Though African Customary Law of Succession is, to a certain extent, being recognised and developed by the Constitutional Court, concepts of succession and ownership continue to be firmly European and capitalist. ${ }^{47}$ This further perpetuates the cycle of colonial apartheid and white supremacy in a document that is supposedly aimed at its overhaul. It is for this reason that Modiri notes the need for an understanding of the law's racial and political nature, as well as a commitment to radical change of the society's power dynamics.

To a certain extent, Langa's visionary Transformative Constitutionalism can be argued to mimic this concern with the morality of laws based on its values-based approach. Langa argues

42 As above.

43 As above.

44 Modiri (n 13) 408.

45 Modiri (n 13) 406.

46 P Langa 'Transformative constitutionalism' (2006) 17 Stellenbosch Law Review at 351. See also sec 25 of the Constitution of the Republic of South Africa, 1996.

47 Modiri (n 13) 408. 
that, in order for the Constitution to succeed in its transformation of society, its value of Ubuntu cannot only be adopted by courts but that they need to be the moral code to which each person is accountable. ${ }^{48}$ This approach, however, has been criticised for being too idealistic to have a tangible effect on achieving substantive justice as it affirms a state of affairs that does not exist in reality. In order for this approach of the transformation of society to be effective, it would have to be the goal of each South African to live in a society where black and white people are equal. This assumption, however, is refuted by Bell who notes that even his most liberal white colleagues have a deep-rooted fear of black success or superiority in any form. 49

Furthermore, the inclusion of a surface-level understanding of Ubuntu in the Constitution acts as an example of the appropriation of African thought for colonial convenience rather than a commitment to epistemological equality. Ubuntu as a philosophical concept has both a cultural and religious significance which is, to a large extent, ignored by the Constitution although transformative constitutionalists claim to adopt it as a value. ${ }^{50}$ By relating the values of Ubuntu to the mutual respect of one another in terms of Western concepts of property rights, whilst blatantly ignoring both its actual meaning and its significance, we are shown the extent to which African philosophy is seen as illegitimate unless it affirms European concepts of justice and morality. This view perpetuates a deep underlying assumption in the fabric of our law and society that black people are inferior.

The constitution can, in these ways, be argued to be an embodiment of the paradoxical nature of a society that supposedly values equality, yet actively seeks to defend the assumption of white superiority. The Constitution has been shown to both adopt and perpetuate the inequality that it supposedly aims to defeat in a manner that reflects the understanding of a black identity, as created by the image of Africa by European colonialists. This would reflect the argument that the law is a reflection of the values held by the society in which it operates, in as much as it would support another argument that radical change of the law will subsequently transform society.

\section{The transformation and decolonisation of knowledge production}

The continued acceptance of Europe's unilateral declaration of itself as both superior and distinct from the rest of the 'barbaric' world,

48

50 Modiri (n 13) 425. See also I Keevy 'Ubuntu versus the core values of the South African Constitution' (2009) (n 2) Journal for Juridical Science at 55. 
despite being refuted on many occasions, mimics the phenomenon of the paradoxical nature of the constitutional era. ${ }^{51}$ In tertiary education systems there exists a simultaneous juxtaposition of the assumption of white supremacy and the academic rebellion against it, which highlights the extent to which entrenched racial biases exist in society. In order to combat this phenomenon, Critical Race scholars encourage a focus on philosophy in their assessment of the value of an interdisciplinary approach to law and a general jurisprudence. Wiredu also argues that a focus on philosophy will not only lead to a better understanding of society but also to an opportunity to change it. ${ }^{52}$. In order to be successful in achieving substantive change, however, the representation of African thought in Academia is called for.

Decolonisation can be argued to be the initial step in the transformation of university spaces as it is the process of removing deeply ingrained colonial biases from thought. However, many scholars argue that this cannot be the only step taken if the damaging effects of centuries worth of racism and bias are to be corrected and substantive equality is to be achieved. ${ }^{53}$ Instead, scholars like Wiredu argue that a greater pressure should be put on academic institutions to consider issues from a variety of different perspectives rather than just one and, in doing so, accept the credibility of African scholarship. ${ }^{54}$ He also argues that philosophical thought requires the assertion of African philosophy as capable of existing in a place outside the realm of 'Western religious and metaphysical assumptions,' and, in doing so, affirm the legitimacy of African thought. 55

The advancement of the both Black Power and Black Consciousness were founded on the rebellion against intellectual subjugation. ${ }^{56}$ Biko, to a large extent, echoes these arguments in saying that, in order for black people to be truly free, black people need to emancipate themselves from the mental attitude of subservience that a white-orientated education has constructed. ${ }^{57} \mathrm{He}$ calls for the resistance of the colonial narrative of African people as barbaric and primitive through the development and practice of both African thought and African culture. ${ }^{58}$ In an echo of Fanon's argument, Biko further argues for the reclaiming of African history in a way that dismisses the colonial narrative of it being no more than

51 Ramose (n 19) 450.

52 P Chatterjee 'The nation in a heterogenous time' in The politics of the governed: reflections on popular politics in most of the world. (2004) 7. See also Wiredu (n 19) 57.

53 Wiredu (n 18) 58.

54 Bell (n 17) 897.

55 Wiredu (n 18) 55.

56 Ranuga (n 1) 183.

57 Biko (n 14) 76.

58 Biko (n 14) 77. 
'long lamentation of repeated defeats. ${ }^{59}$ In this way, the reclaiming of knowledge and scholarly resistance are highlighted as key features of substantive change. ${ }^{60}$

For centuries, African people have been made to struggle against what Mangcu labels an 'evidentiary genocide' in which formative moments in South African history have been ignored or appropriated by the media and state. ${ }^{61}$ Mangcu argues that the archive of history has been constructed to privilege certain narratives over others, and, in doing so, excludes important voices and contributions. ${ }^{62}$ At the same time, Mangcu cautions against a singular narrative of African history. ${ }^{63}$ One needs to understand the various nuances and philosophical disagreements that exist within the realm of African academia. He disproves the single narrative by examining historical inaccuracies. In this way, Mangcu argues for a critical approach not only to education but to society as a whole, as he criticises the fact that the efforts of post-1994 'nation building' are not only politically charged, but are also based on an assumption of the unequal value of particular narratives.

To a large extent, this is a key feature of Critical Race theory in that, as Bell notes, many critical race scholars adopt scholarly resistance to white privilege in the hope that this will lead to societal resistance. ${ }^{64}$ Because society is a macrocosm of the university setting and vice versa, these two intellectual spaces share a symbiotic link in which the attitudes of one are reflected in the other on a lesser or grander scale. If, as Modiri argues, the realm of tertiary education exists as a microcosm of society, approaching various academic disciplines with critical thought and a broader understanding of the power of the historical narrative can undo the deeply entrenched racist assumptions when reflected in the attitudes of the public. It is for this reason that Critical Race scholars call not only for the representation of African voices in academic discourse, but for the understanding of these narratives as equal and legitimate.

In order to truly give representation of African philosophy, Wiredu places emphasis on the importance of recognising the legitimacy of African languages. He argues that many African scholars may not even be aware of the fact that their philosophy is being impeded upon by colonial ideologies, and, in order to overcome this, African thought needs to be considered in the vernacular of African people. ${ }^{65} \mathrm{He}$

59 Biko (n 14) 76. See also Ranuga (n 1) 184.

60 Chatterjee (n 52) 7.

61 X Mangcu 'Evidentiary genocide: Intersections of race, power and the archive' in Mangcu X (eds) Becoming worthy ancestor: Archive, public deliberation and identity in South Africa (2011) 2 \&4.

62 Mangcu (n 61) 12.

63 As above.

64 Bell (n 17) 901.

65 Wiredu (n 8) 56. 
argues that this will ultimately contribute to the process of 'conceptual decolonization." 66 This will also combat the colonial assumption of language not being legitimate unless it is white. ${ }^{67}$

One cannot believe that we exist in a neutral society and, to a certain extent, this neutral society is not desirable. Bell argues that education cannot be sanitised or distilled to a single objective truth and that this truth acts as a mere mask for the agenda of perpetuating white privilege. ${ }^{68} \mathrm{He}$ argues that academia needs to be placed within its context and thus, situated within the experiences of people. ${ }^{69}$ This approach aims to close the gap between the paradoxical nature of the constitution and law and society. In this way, Critical Race academics develop a preference for a 'general jurisprudence' in which legal scholarship is not separated from various humanitarian disciplines such as those of politics and philosophy. Transforming these realms in a scholarly context has been argued to lead to actual resistance.

\section{Conclusion}

The call for transformation necessitates the acknowledgement of the context of the law and academia, and, in doing so, understanding the various nuances of and approaches to black identity in both historical and contemporary society. This society cannot be equal if one group of people need to work much harder than their white counterparts, in order to have their existence legitimised and their success recognised. Furthermore, conceptions of a shared identity or task of building a nation based on equality cannot exist while groups of people are silenced. For these reasons, despite constitutional assurances of the contrary, both the South African academic landscape and society cannot be described as free or equal, but instead, as encompassing a deep colonial bias.

Academia, legal scholarship and the law in general are innately linked to the power dynamics that exist within societal structures. Though there has been a call for the transformation of these various realms of society, the advancement of the Constitution has not done away with the faulty assumptions of scientific racism and black inferiority in the face of European thought. The only way to undo this inherent racism of South African and global societies is to approach historic and philosophical discourse critically, with as much acknowledgement of silent voices as those who take it upon themselves to portray the narrative. ${ }^{70} \mathrm{It}$ is for this reason that Critical

66 Wiredu (n 8) 59

67 Mudimbe (n 7) 57.

68 Bell (n 17) 901.

69 As above.

70 Mangcu (n 61) 12. 
Race scholarship is not only a benefit to academic and legal studies but a necessity for the substantive transformation of society and the achievement of justice. 


\section{THROUGH THICK AND THIN: FROM THE REGULATION OF QUEERNESS TO QUEER THEORY AS DECOLONISATION}

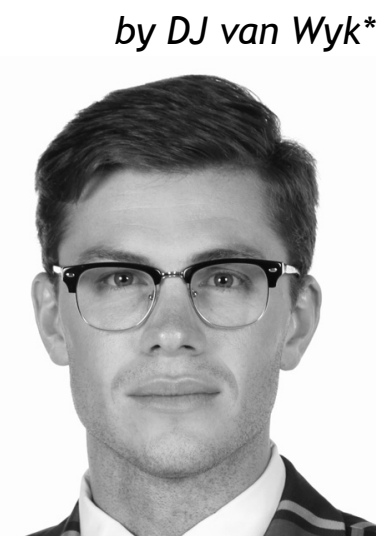

"African "homosexualities" can never be comfortably slotted within identity politics carved out of Western "gay" and "lesbian" liberation struggles, and display queer and even post-queer characteristics'.*

\section{Introduction}

The purpose of this essay is to investigate, criticise and recontextualise the concept of queerness in South Africa. I will do this by focusing on the historical regulation of queerness, the attempted transformation of queerness and the inevitable decolonisation of queerness. With the above established, and before proceeding, it is essential to understand the terminology that will be used in this essay. Queer is an alternative umbrella term 'which embraces a matrix of sexual preferences, orientations, and habits'. 1 Queer includes the same non-normative, sex-gender-sexuality identities as

* C Zabus 'Apartheid, queerness \& diaspora' in S Boydell \& J Brewer (eds) In out in Africa: Same-sex desire in sub-saharan literatures and cultures (2013) 188.

** LLB III (BSC), University of Pretoria. I would like to express my utmost gratitude and appreciation for Ms Zenia Pero (Academic Associate, Department of Jurisprudence) as she provided me with valuable academic advice, emotional support and motivation. I would also like to thank Nicholas Herd and Mex $M^{\prime}$ 'membe, who are two of the closest people in my life, for all the support they offered throughout this writing process

1 N Giffney “Introduction: The “q” word' in N Giffney (ed) The Ashgate companion to queer theory (2009) 2. 
LGBT-Q but it exceeds the limits of that term and further represents those who are gender non-conforming. ${ }^{2}$ The concept of queerness stems from this word and usually symbolises being against the norm or ab-normal. Whether this norm is heterosexuality or dominant gay identity - queerness goes against the norm and is seen as being definitively different. ${ }^{3}$

A brief inquiry into South Africa's history will show that sexuality and identity were rigorously regulated concepts during Apartheid. Homophobic laws, and the dominance of Christianity, resulted in the discrimination and marginalisation of queer people during the regime. ${ }^{4}$ After 1994, the Constitution of the Republic of South Africa (hereafter 'The Constitution') brought forward values of equality, freedom and human dignity that resulted in the prohibition of discrimination on the basis of sexual orientation. ${ }^{5}$ Additionally, legislative and judicial advances, such as the Civil Union Act 17 of 2006 (hereafter 'Civil Union Act') and the Minister of Home Affairs and Another $v$ Fourie and Another (hereafter 'Fourie') judgment ensured that same-sex partnerships were afforded a level of recognition and protection alongside the Marriage Act 25 of 1961 (hereafter 'Marriage Act'). ${ }^{6}$ These transformative mechanisms were accompanied by developments in queer theory and gender studies that questioned the nature of same-sex marriage and queer identity. In essence, queerness has faced many hardships and successes that must be critically investigated and analysed.

This critical investigation and analysis will be centred around three main questions regarding queerness: (1) How queerness has been regulated by western and apartheid concepts of social interaction?; (2) How queerness has been transformed in Post-1994 South Africa - specifically before and after the implementation of the Civil Union Act?; and (3) How can the current marriage systems - and queerness - be decolonised using queer theory? I will approach this essay using concepts of transformative constitutionalism, queer theory, and decolonial theory. By answering these three questions, I aim to prove that queerness (as a concept and identity) is something that requires sufficient decolonisation because it has been historically regulated, inaccurately defined and inadequately transformed. Furthermore, I will demonstrate how legal systems and knowledge, dealing with queerness, ought to be interrogated and altered to best represent queer people.

2 As above.

$3 \quad M$ van Zyl 'A sexual politics of belonging: Same-sex marriage in post-apartheid South Africa' PhD thesis, University of Stellenbosch, 2015 at 3.

$4 \mathrm{H}$ de Ru 'A historical perspective on the recognition of same-sex unions in South Africa' (2013) 19 Fundamina at 250.

$5 \mathrm{Sec} 9(3)$ of the Constitution of the Republic of South Africa 1996.

6 Minister of Home Affairs and Another v Fourie and Another 2006 (1) SA 524 (CC); De Ru (n 4) 250. 


\section{The regulation of queerness}

South Africa's constitutional history is plagued by two problematic systems: an institutionalisation of racism and a bias shown towards certain brands of Christianity. Using these two systems, the Apartheid government created a culture of state interference whereby the state would construct the identities, and regulate the private lives, of black and queer individuals. ${ }^{7}$ As a result of this, racist and biblical concepts of social interaction became institutionalised and they had a profound effect on queer people and social interactions in pre-1994 South Africa. ${ }^{8}$ The bias shown towards Christianity resulted in religiously influenced laws being passed that destroyed the sanctity of queer private lives that were seen 'strange' and 'not religiously normal'. '

Originally, it was seen as a common law offence when males engaged in sexual intimacy with each other (sodomy). At the same time, the Immorality Act prohibited 'any unnatural sexual acts' in general and regarded same-sex relations as unnatural, criminal and deviant. ${ }^{10}$ Further apartheid legislation, such as the Sexual Offences Act, criminalised any sexual acts between males that intended to bring about sexual pleasure. ${ }^{11}$ This form of 'naked hatred' towards queer people was a violent limitation of their freedoms and choices to partake in intimacy and relations with one another. ${ }^{12}$ Queer people across the spectrum were classified as criminals and perverts and thus, socially excluded and marginalised by broader South African society. ${ }^{13}$ This was the beginning of legally constructed differences between heterosexuals and homosexuals, whereby the government would socially construct sexuality into something detestable. ${ }^{14}$

With regards to same-sex marriage, the traditional concept of marriage is still seen as: 'a voluntary union for life between one man and one woman to the exclusion of others while it lasts'. ${ }^{15}$ This concept emanated from religious western countries such as Holland and England and it formed part of their marriage laws (Roman-Dutch Law and Common Law). ${ }^{16} \mathrm{~A}$ deeper analysis of this concept will show

7 De Ru (n 4) 225

8 P De Vos \& J Barnard 'Same-sex marriage, civil unions and domestic partnerships in South Africa: critical reflections on an ongoing saga' (2007) 124 South African Law Journal at 796.

9 J Barnard 'Totalitarianism, (same-sex) marriage and democratic politics in post1994 South Africa' (2007) 23 South African Journal of Human Rights at 501.

10 De Vos \& Barnard (n8) 797; Immorality Act 21 of 1950.

11 Sec 20A Sexual Offences Act 23 of 1957.

12 De Vos \& Barnard (n8) 797.

13 National Coalition for Gay and Lesbian Equality v Minister of Justice 1999 (1) SA 6 (CC) paras 27-28.

$14 \mathrm{~K}$ van Marle \& $\mathrm{E}$ Bonthuys 'Feminist theories and concepts' in C Albertyn \& E Bonthuys (eds) Gender, Law and Justice (2007) at 25.

15 De Ru (n4) 221; Ismail v Ismail 1983 (1) SA 1006 (A).

16 H Hahlo \& E Kahn The South African legal system and its background (1968) 511. 
that Euro-Western societies incorporated Christian-centred principles of anti-divorce ('for life'), heterosexuality ('one man and one woman') and monogamy ('to the exclusion of others') into their fundamental ideals of marriage. ${ }^{17}$ These Euro-Western ideals above were brought to Africa by the European colonisers and they were implanted into some African societies that already supported and practiced forms of homosexual marriage, polygynous marriage, and the pursuance of intimacy outside of formal relationships. ${ }^{18}$ However, there were African cultures that did not accept and support homosexuality in any form and the implantation of Euro-Western Christianity reinforced the already dominant cultural narrative that existed. ${ }^{19}$ Essentially, the principles of a Christian-marriage and the imposition of colonialism caused heterosexual-monogamy to be the generally 'enforced' marriage system in South Africa. ${ }^{20}$ Furthermore, these principles were used to construct gender, race and sexuality in such a way that marginalised individuals lost their own sense of self. An example of this is the way in which sexuality was constructed to exclude diverse same-sex practices in African cultures. ${ }^{21}$

A further aggravating factor was that courts did not have the ability to question any of these laws or regulations due to parliamentary sovereignty. ${ }^{22}$ Thus, queer people were left with very few defences as the courts had to implement homophobic legislation formalistically, and not question it. ${ }^{23}$ These political and judicial practices fixed sexuality onto an individual person and they showed a blatant disregard for human connection and morality. ${ }^{24}$ Traditional, legal and scientific discussions about sexuality focused purely on procreation between two heterosexual partners and they failed to recognise that queer identities and interactions existed within sexuality. This systemic failure to recognise a group of people, due to their identity, is one of the main points of regulation and suppression faced by queer people. ${ }^{25}$ Objectively, queerness was being regulated through governmentally-enforced laws that were extremely oppressive and homophobic in nature. Furthermore, it can be argued that homophobia was colonially constructed and implanted into communities that previously had no problem with homosexuality because this would secure the hegemony the government had. ${ }^{26}$

17 H Hahlo The South African Law of Husband and Wife (1985) 21.

18 B Dlamini 'Homosexuality in the African Context' (2006) 67 Agenda: Empowering Women for Gender Equality at 130-132; Hahlo (n17) 14.

19 Dlamini (n18) 133-134.

20 Van Zyl (n3) 7.

21 E Bonthuys 'Race and gender in the Civil Union Act' (2007) 23 South African Journal of Human Rights at 541.

22 W Hosten et al Introduction to South African law and legal theory (1995) 337.

$23 \mathrm{~J}$ Robinson "The evolution of the concept of marriage in South Africa: the influence of the evil of rights in 1994' (2005) 26 Obiter at 489.

24 Van Zyl (n 3) 7.

25 Van Zyl (n 3) 7.

26 Van Zyl (n 3) 8. 
The totalitarianism of the apartheid regime was so rigorous that no queer rights movements took place before the 1980s. ${ }^{27}$ All gay liberation movements were met with elements of force and suppression because they were seen as directly challenging the apartheid government. However, during the 1980s and 1990s, many different movements and organisations were established that focused on the advancement and protection of queer people. ${ }^{28}$ These movements would form alliances with racial and feminist antiApartheid movements because they argued that their oppression stemmed from the same source - the Apartheid government. ${ }^{29}$ Internal tensions emerged in these organisations because queer members couldn't decide between offering support or advancing activism. These internal tensions hindered the queer movements because many members felt that they were being regulated and suppressed by other queer bodies in the movements. This form of internal regulation of queerness was additional to the external regulation of queerness enforced by the government. Racial and gender divides were also contributing factors to the internal regulation of queerness that occurred throughout the community. ${ }^{30}$ White gay men experienced significant amounts of preferential treatment when compared to black gay men and lesbian women. An example of this was that black gay men were prevented from accessing the same bars and gatherings as white gay men because of racial segregation that took place during apartheid. ${ }^{31}$ Furthermore, white conservative queer people did not want to identify with any form of political struggle or movement because they were comfortable in the 'bar-cruising' lifestyle that they found themselves in. ${ }^{32}$ Pierre De Vos argues that the reluctance by white queer people to join movements and foster inclusivity was a strategy used to uphold a standard of white 'purity' and 'class' that they also ascribed to. ${ }^{33}$ This shows that black and female queerness faced regulation from all societal fronts - including their own community of queer people.

The internal and external regulation of queerness was difficult to overcome during apartheid and it hindered the advancement of queer issues and identities in South Africa. ${ }^{34}$ The fall of Apartheid brought forward a new era established under a Constitution that enshrined principles of equality, freedom and human dignity. ${ }^{35}$ The legal

27 Barnard (n 9) 501.

28 J Cock 'Engendering gay and lesbian rights: The equality clause in the South African Constitution' (2002) 26 Woman's Studies International Forum at 37.

29 De Ru (n 4) 222.

30 Van Zyl (n 3) 9-10.

31 Van Zyl (n 3) 9.

32 Van Zyl (n 3) 10.

33 De Vos \& Barnard (n 8) 798.

34 M Nell \& J Shapiro 'Out of the box: Queer youth in South Africa' (2011) 16 The Atlantic Philanthropies at 12.

35 Secs 9-10 of the Constitution; De Ru (n 4) 250. 
recognition and equality given to queer people meant that they could challenge religious and ideological systems that previously oppressed them. ${ }^{36}$ Thus, a movement towards transforming and decolonising institutions and concepts began.

\section{The transformation of queerness}

\subsection{Transformative constitutionalism - Section 9(3)}

Oppression, inequality and hatred are characteristics that can be used to define the apartheid regime. Thus, after the fall of apartheid, South Africa needed large-scale social, legal and political transformation. ${ }^{37}$ The post-1994 Constitution was adopted to give effect to this transformative goal and change society. ${ }^{38}$ Additionally, the concept of transformative constitutionalism emanated from the Constitution and it can be defined as:

a long-term project of constitutional enactment, interpretation, and enforcement committed to transforming a country's political and social institutions and power relationships in a democratic, participatory, and egalitarian direction. ${ }^{39}$

One of the biggest contributing factors towards transformation was, and still is, section 9 of the Constitution. The inclusion of sexual orientation in section $9(3)$ resulted in discrimination, on the grounds of sexual orientation, being prohibited. ${ }^{40}$ This meant that any discriminatory and oppressive statutes, aimed at queer people, could now be declared unconstitutional. ${ }^{41}$ Moreover, queer organisations strategically used section $9(3)$ to gain additional rights and this ensured that social transformation could take place in a non-violent manner that upheld the values of transformative constitutionalism. ${ }^{42}$ Ultimately, queer individuals were able to attain a sense of peace and justice using this transformative provision. It signalled the end of queer repression, and the beginning of queer inclusion. ${ }^{43}$ The only problem was that - the Constitution was only a protective and equitable mechanism for marginalised individuals. The Constitution never advanced or called for the deconstruction of harmful colonial constructs surrounding race, gender and sexuality.

36 De Ru (n 4) 222.

37 K Klare 'Legal culture and transformative constitutionalism' (1998) 14 South African Journal on Human Rights at 150.

38 Preamble of the Constitution of the Republic of South Africa 1996.

39 Klare (n 37) 150.

40 De Ru (n 4) 250.

41 Bonthuys (n 21) 528.

42 Klare (n 37) 150.

$43 \mathrm{~V}$ Reddy 'Decriminalisation of homosexuality in post-Apartheid South Africa: A brief legal case review from sodomy to marriage' (2006) 67 Agenda: Empowering Women for Gender Equity at 148. 
Transformative adjudication and transformative law making were mechanisms used to facilitate the decriminalisation of queer identity. Transformative judgments that brought an end to unconstitutional laws and transformative statutes that legalised previously illegal interactions formed part of Karl Klare's definition of transformative constitutionalism ('constitutional interpretation and enactment'). ${ }^{44}$ The transformation of social and legal perspectives surrounding queerness resulted in the recognition, and expression, of queer individuals who had never had the opportunity to do so during apartheid. ${ }^{45}$ Queer people now occupied a space in South African society and many judgments reflected this in landmark rulings.

\subsection{Transformative adjudication - pro-queer litigation}

Apartheid legal culture practiced a form of restricted jurisprudence that can be described as formalistic and positivist in nature. ${ }^{46}$ This approach persisted throughout because parliamentary sovereignty supported a positivist legal theory of law. This meant that judges had to strictly and simply apply homophobic and oppressive laws made by political superiors. ${ }^{47}$ The post-1994 Constitution changed this by incorporating values and principles that needed to be considered in all legal matters. A constitutional interpretation can be described as practicing general jurisprudence as it aims to harmonise legal interpretation with substantive societal goals. ${ }^{48}$ The National Coalition for Gay and Lesbian Equality $v$ Minister of Justice is an example of this form of jurisprudence because the court held that the common law offence of sodomy violated queer men's rights to dignity and equality. ${ }^{49}$ When making this decision, the Court considered the historical oppression that queer men faced and furthermore, the court advanced the concept of transformative constitutionalism to ensure that queer identity was protected. ${ }^{50}$

In the Minister of Home Affairs $v$ Fourie case, the Marriage Act, which codified the common-law definition of marriage, was constitutionally challenged. ${ }^{51}$ The Constitutional Court held that the common law definition was inconsistent with the Constitution and furthermore, section 30(1) was declared invalid because it prevented same-sex couples from accessing the same status and benefits as heterosexual couples. ${ }^{52}$ Sachs $\mathrm{J}$ stated the following:

44 Klare (n 37) 150; Reddy (n 43) 146.

45 As above.

46 C Douzinas \& A Gearey Critical jurisprudence:The political philosophy of justice (2005) 6.

47 A van Blerk Jurisprudence: An introduction (1998) 29.

48 Klare (n 37) 188; Douzinas \& Gearey (n46) 10.

49 National Coalition for Gay and Lesbian Equality (n 13) para 62.

50 Reddy (n 43) 149.

51 Fourie (n 6) para 67.

52 De Vos \& Barnard (n 8) 824; Fourie (n 6) para 67. 
the exclusion of same-sex couples from the benefits and responsibilities of marriage is not a small and tangential inconvenience ... It represents a harsh statement by the law that same-sex couples are outsiders, and that their need for affirmation and protection ... is somehow less than that of heterosexual couples. ${ }^{53}$

In the above statement, Sachs $J$ demonstrates a general jurisprudential approach to interpretation that incorporates morality and values. ${ }^{54}$ This approach is fundamental to transformative adjudication because its successful application will result in equitable outcomes which are necessary for transformation in society. ${ }^{55}$ Etienne Mureinik stated that South African law has to develop into a culture of justification that is self-conscious and reflective. He argues that: values, principles and texts need to be analysed to produce the most reasoned justification for legal matters. ${ }^{56}$ The Fourie case is an example of this.

Moreover, various courts have consistently upheld the principles of human dignity, equality and freedom when dealing with same-sex relationships. In many pro-queer cases, the courts have played a role in further transforming the lives of queer people. ${ }^{57}$ Examples of this include; giving queer couples the ability to adopt children, allowing same-sex life partners the ability to claim damages from the Road Accident Fund, and giving same-sex life partners a claim to maintenance if they are financially dependent. ${ }^{58}$ Essentially, rights and privileges are being extended to queer individuals on a public platform. Thus, queer identity was given the opportunity to develop and gain awareness but in a violent fashion because of resistance by the state and backlash from the public. ${ }^{59}$

The Constitution can be defined as a document of historical selfconsciousness and transformation. ${ }^{60}$ With that said, the Constitutional Court has regularly emphasised that the progressive effect of transformative adjudication cannot be limited to interpretation alone. ${ }^{61}$ Thus, in the Fourie case, the court went a step further and ruled that parliament must enact legislation that remedies the constitutional issues outlined in the case. ${ }^{62}$

53 Fourie (n 6) para 78

54 Douzinas \& Gearey (n 46) 10.

55 Klare (n 37) 163.

56 E Mureinik 'A bridge to where? Introducing the Interim Bill of Rights,' (1994) 10 South Afrcian Journal of Human Rights at 31-32; Klare (n37) 147.

57 De Vos \& Barnard (n8) 800.

58 Du Toit and Another $v$ Minister of Welfare and Population Development and Others 2003 (2) SA 198 (CC); Du Plessis v Road Accident Fund 2004 (1) SA 359 (SCA); Langemaat $v$ Minister of Safety and Security 1998 (3) SA 312 (T).

59 Reddy (n43) 150-151.

60 Klare (n 37) 155.

61 Klare (n 37) 150; De Vos \& Barnard (n 8) 801.

62 Fourie (n 6) para 80. 


\subsection{Transformative law making - the Civil Union Act}

Before 2006, same-sex marriage was not recognised in South African law because it fell outside the scope of religious, statutory and common-law principles of marriage. ${ }^{63}$ The Marriage Act was the only statute regulating marriage in South African family law until 2000. The Recognition of Customary Marriages Act was then enacted and it regulated customary marriages in South Africa. ${ }^{64}$ However, these civil and customary marriage systems only recognised, and protected, heterosexual marriages. Many members of the queer community challenged this perception because it was a form of social exclusion and inequality that resembled the treatment of queer people during Apartheid. ${ }^{65}$ The Fourie case was a fundamental actor in addressing this and was a catalyst for future same-sex marriage legislation. In this case, the Constitutional Court demonstrated a willingness to advance cultural politics and uphold the notion of multiculturalism and diversity. ${ }^{66}$ Requiring parliament to enact same-sex marriage legislation can be seen as a step towards national reconciliation and furthermore, it promotes the realisation of justice and rights for vulnerable identity groups. ${ }^{67}$

In 2006, the African National Congress tabled the Civil Union Bill in Parliament. ${ }^{68}$ The majority party had to comply with the ruling in the Fourie case even though the majority of their supporters opposed the Bill. After many debates and opportunities for public participation, parliament enacted the Civil Union Act which permitted anyone - both heterosexuals and homosexuals - to conclude a monogamous marriage in terms of the Act. ${ }^{69}$ The Preamble to the Civil Union Act recognises that South African family law failed 'to provide for same-sex couples to enjoy the same status and benefits ... as heterosexual couples'. ${ }^{70}$ Section 1 of the Act defines a civil union as:

the voluntary union of two persons who are both 18 years or older, which is solemnised and registered by way of either a marriage or a civil partnership, in accordance with the procedures prescribed in this Act, to the exclusion, while it lasts, of all others. ${ }^{71}$

63 J Sinclair \& J Heaton The Law of Marriage (1996) 305; Reddy (n 43) 152.

64 Recognition of Customary Marriages Act 120 of 1998; De Vos \& Barnard (n 8) 824.

65 Reddy (n 43) 153.

66 Klare (n 37) 155.

67 As above.

68 Parliamentary Monitoring Group Committee Report, https://pmg.org.za/commi ttee-meeting/7587/ (accessed 26 May 2019).

69 B Goldblatt 'Same-sex marriage in South Africa: The Constitutional Court's judgment' (2006) 14 Feminist Legal Studies at 261.

70 Preamble of the Civil Union Act 17 of 2006.

71 Sec 1 of the Civil Union Act 17 of 2006. 
Section 13(1) of the Act states that the legal consequences found in the Marriage Act, must apply to civil unions concluded in terms of the Civil Union Act. ${ }^{72}$ Thus, the preamble and the above-mentioned provisions demonstrate that the Act intended to achieve three things: (1) to extend formal rights to queer couples; (2) to add substantive rights that equalised the social meaning of marriage; and (3) to transform the centralised concept of marriage. ${ }^{73}$

Enacting legislation forms part of the legalisation campaign that ensures the allocation of rights to queer individuals. ${ }^{74}$ It is evident that same-sex marriage legislation embodies the idea of social transformation envisaged by the Constitution. The legislation questions traditional views regarding marriage and it transforms queerness into a legally accepted and recognised construct. ${ }^{75}$ This results in an emphatic transformation of social interaction because recognition, protection and inclusion are advanced in broader society. ${ }^{76}$ Thus, the Constitutional goal of social transformation is achieved, to some extent, using transformative law making.

\subsection{Criticisms regarding the transformative approaches}

Questions arise when these transformative mechanisms are deeply analysed using the Constitution. One question is: have these transformative approaches achieved political freedom and socioeconomic justice for queer people? ${ }^{77}$ Second, has queerness been transformed and deconstructed to such an extent that queer people are able to freely exist and express themselves? I put forward a criticism that says no.

Section 6 of the Civil Union Act answers both of the questions in the negative. Section 6 gives state individuals the power to refuse solemnising homosexual civil unions based on religion, conscience and belief. ${ }^{78}$ Thus, any state officials can rely on of these grounds, which inform their personal belief systems and prevent the actualisation of rights afforded to same-sex couples. The ability to discriminate against same-sex couples reinforces the idea that same-sex couples are constructed as 'inferior' and 'unwanted'. ${ }^{79}$ Thus, queerness is not

72 Sec 13 of the Civil Union Act 17 of 2006.

73 D Bilchitz \& M Judge 'For whom does the bell toll? The challenges and possibilities of the Civil Union Act for family law' (2007) 23 South African Journal of Human Rights at 484.

74 Reddy (n 43) 155.

75 Van Zyl (n 3) 8

76 Reddy (n 43) 155.

77 Klare (n 37) 154.

78 Sec 6 of the Civil Union Act 17 of 2006.

79 Daily Maverick, P De Vos \& J Barnard-Naude 'Legislation still not recognising problem of "separate but equal" same-sex marriage' 30 November $2018 \mathrm{https}$ :// www.dailymaverick.co.za/article/2018-11-30-legislation-still-not-recognisingproblem-of-separate-but-equal-same-sex-marriage/ (accessed 16 May 2019). 
actually transformed by the Civil Union Act because section 6 leaves queer people open to discrimination from a heteronormative state. ${ }^{80}$ A legislative solution has been brought forward in the form of an Amendment Bill which was tabled in 2018. This Bill has been passed in the National Assembly (and will be going to the National Council of Provinces), and its purpose is to repeal the controversial section from the Act. ${ }^{81}$ Thus, an effort has been shown to cure the unconstitutionality of the Act and advance the movement towards recognition and protection for queer bodies.

With that said and the abovementioned being progressive on paper, two problems still exist with regards to the proposed Amendment Bill. The first problem is that the Amendment Bill delays the implementation of the amendment by 24 months. ${ }^{82}$ The transitional period has been put in place so that the Department of Home Affairs has sufficient time to train and educate the current marriage officers who have readily relied on section 6 of the Act. ${ }^{83}$ This transitional period is problematic in the sense that it keeps the section operational for another 24 months and allows for marriage officials to carry on discriminating against queer bodies who want to get their unions solemnised. Furthermore, this becomes practically questionable because the procedures currently used for solemnising heterosexual marriages should be exactly the same as the procedures that will be implemented for solemnising homosexual unions. Thus, why the need for this 24 -month training period? ${ }^{84}$ The second problem is that no effort has been shown to deconstruct the western constructs around gender and sexuality. What I mean by this is that this Amendment Bill does not do enough to change the current Marriage Act, or better yet, do away with the Civil Union Act and instead have one piece of legislation that regulates marriages and unions across the spectrum. De Ru argues that the notion of 'separate but equal' is utilised to reinforce the desired constructs and hegemony of the state. ${ }^{85}$ The Civil Union Act relegates same-sex marriage to a second-class status and it creates further marginalisation and oppression for queer people. ${ }^{86}$ Thus, the Amendment Bill should not have simply targeted one section but rather, it should have targeted the entire Act and other Acts that it is in proximity to.

80 As above.

81 Section 1 of the Civil Union Amendment Bill B11-2018.

82 Section 2 of the Civil Union Amendment Bill B11-2018.

83 As above.

84 Daily Maverick (n 79) https://www.dailymaverick.co.za/article/2018-11-30-legis lation-still-not-recognising-problem-of-separate-but-equal-same-sex-marriage/.

85 De Ru (n 4) 248.

86 As above. 
With that established, my critical focus will shift to the Marriage Act and its constitutionality. ${ }^{87}$ To a large extent, there are no significant differences between the Civil Union Act and the Marriage Act. Rights and obligations were almost identical in both Acts thus, the Civil Union Act never altered the gender and sexuality constructs imposed by the Marriage Act. ${ }^{88}$ The only clear difference is the fact that heterosexual couples can choose to get married in terms of the Marriage Act and Civil Union Act, whereas homosexual couples can only get married in terms of the Civil Union Act. This distinction creates a superiority complex in heterosexual couples because they are given an extra choice regarding marriage. This extra choice means that they can choose to exclude themselves from 'unwanted' homosexual couples who use the Civil Union Act. ${ }^{89}$ The existence of such inequality proves that the Marriage Act has questionable constitutionality and decolonial outlooks. Even after the Fourie case, the codified common-law definition remained in the Marriage Act. ${ }^{90}$ Thus, I submit that the only constitutional options for the transformation and decolonisation of queerness are: (1) opening the Marriage Act to same-sex partners or (2) repealing the Marriage Act, Civil Union Act and Recognition of Customary Marriages Act and enacting a single marriage statute for all marriages. ${ }^{91}$ The second option is also purported by the South African Law Reform Commission (SALRC) in Issue Paper 35 which details project $144 .{ }^{92}$ This project focuses on the idea of a single marriage statute and in it, the SALRC outlines the quest for a unified and uniform marriage legislation. ${ }^{93}$ The Issue Paper contains two clear positions regarding the subject of a single marriage statute. The first is:

The SALRC noted that South Africa's new Constitution provided the opportunity to make a break with the past and to send a clear message that discrimination would no longer be tolerated. The SALRC was of the view that that message had to be reflected in the principle of a single marriage law which would apply equally to all South Africans. ${ }^{94}$

The second is:

A single marriage statute can take two different forms - either a unified set of requirements (and possibly consequences) applying to all marriages or alternatively a single act which contains different chapters

Daily Maverick (n 79) https://www.dailymaverick.co.za/article/2018-11-30-legis lation-still-not-recognising-problem-of-separate-but-equal-same-sex-marriage/.

88 E Bonthuys 'Irrational accommodation: conscience, religion and same-sex marriage in South Africa' (2008) 125 South African Law Journal at 477.

89 De Vos \& Barnard (n 8) 821.

90 As above.

91 Daily Maverick (n 79) https://www.dailymaverick.co.za/article/2018-11-30-legis lation-still-not-recognising-problem-of-separate-but-equal-same-sex-marriage/

92 South African Law Reform Commission Issue Paper 35 'Project 144: Single Marriage Statute' (2019).

93 South African Law Reform Commission Issue Paper 35 (n 92) 5-6.

94 South African Law Reform Commission Issue Paper 35 (n 92) 6. 
which reflect the current diverse set of legal requirements for and consequences of civil marriages, civil unions, customary marriages, Muslim and possibly other religious marriages...The academic consensus seems to be in favour of the creation of a single basic statute to govern different cultural, religious and secular marriages rather than retaining the current piecemeal situation. ${ }^{95}$

Transforming South Africa and removing the stains of apartheid can be a long and tedious process. The Constitution is an instrument available to citizens and legal practitioners and it can be used to successfully complete this process. ${ }^{96}$ However, to achieve sufficient transformation, we cannot be hesitant or selective when deconstructing the problematic notions around sexuality and gender. The decision to separate homosexuals from heterosexuals meant that they were not worthy of integration and consideration. ${ }^{97}$ This has exposed South Africa as a country that narrowly defines freedom and human existence. Furthermore, it shows that queer problems and problems of equity remain unresolved. ${ }^{98}$ The Civil Union Act was an extremely progressive step for South Africa - but the implementation never questioned the colonial construct of sexuality and gender. Thus, it was ineffective in decolonising queerness and ensuring that queer identities were developed.

\section{The decolonisation of queerness}

The current, post-colonial, approach used to attain queer liberation is transformative in nature. The Civil Union Act is one mechanism being used to transform marriage systems and queerness in South Africa. However, the identifiable problem is the fact that it is not queer or decolonial in nature. True liberation and transformation can only be achieved if queerness is decolonised and moved away from the colonial constructs that regulate it today. ${ }^{99}$ A disassociation from, and a deconstruction of, western norms is needed for decolonisation to take place. As outlined above, the transformative Civil Union Act makes detrimental concessions to colonialism thus, it merely advances rights at the expense of queer identities. ${ }^{100}$ In this section, I will highlight the three theories that can be used to adequately decolonise queerness and ensure the removal of social constructs that limit queer identity.

95 South African Law Reform Commission Issue Paper 35 (n 92) 15.

96 Klare (n 37) 155.

97 J Landau 'Marriage as integration' in A Sullivan Same-sex marriage pro \& con - A reader (2004) at 319.

98 A Mbembe 'At the centre of the knot' (2012) 38 Social Dynamics at 12.

99 De Vos \& Barnard (n 8) 821.

100 C Douzinas 'Human rights and post-modern utopia' (2000) 11 Law and Critique at 232. 


\subsection{Queer, decolonial and feminist theories}

'Queer' is not just an umbrella term for the LGBT-Q community - it is a term that allows you to think differently about your identity and surroundings. ${ }^{101}$ It is characterised as a form of resistance and celebration that seeks to disturb identities, not define them. By doing so, it represents anyone that rejects the 'white heterosexual middle class' norm and stereotype. ${ }^{102}$ Noreen Giffney maintains that the term 'queer' recognises identity as socially constructed thus, it emphasises self-reflection and fluidity to overcome this. She further argues that, queerness is essentially the 'disidentification' from categories perpetuated by religious and government institutions. ${ }^{103}$ Queer theory stems from the concept of queerness and it is a mode of thinking that questions the positionality of queerness in society. ${ }^{104}$ It is an analytical tool that interrogates the historical and modern codes of behaviour that seek to regulate queerness. In essence, it aims to critique the previous methods used to conceptualise identity. ${ }^{105}$ What queer theory aims to do is question the fixed, and stable, identitycategories that exist in society. Furthermore, it is aimed at breaking down the perpetuation of categories that cause significant harm to those in marginalised positions. ${ }^{106}$ Thus, queer theory is both a theoretical, and practical, mechanism that questions identity beyond what is socially constructed as identity. ${ }^{107}$

Queer theory intersects with the goals of decoloniality in many ways. Both theories question the structure of identity and problematise the incorporation of colonial constructs. ${ }^{108}$ The need to decolonise is urgent because African and queer identities have been restricted to such an extent that they no longer resemble what they once were, or what they could be. African and queer individuals are overwhelmed with western religions and norms and this fundamentally diminishes their ability to construct unique individual identities. ${ }^{109}$ Decolonial theory seeks to eliminate concepts that emanated from colonial sources and furthermore, it seeks to remove

101 Giffney (n 1) 1.

102 The Conversation, TL McCormick 'Why same-sex marriage is not the ultimate tool for queer liberation' 14 October 2018 https://theconversation.com/why-samesex-marriage-is-not-the-ultimate-tool-for-queer-liberation-103702 (accessed 26 May 2019).

103 Giffney (n 1) 3.

104 TL Mccormick (n 102) https://theconversation.com/why-same-sex-marriage-isnot-the-ultimate-tool-for-queer-liberation-103702.

105 K Watson 'Queer Theory' (2005) 38 Group Analysis at 68, 67-81; Giffney (n 1 ) 4.

$106 \mathrm{~J}$ Gedro \& R Mizzi 'Feminist theory and queer theory: Implications for HRD research and practice' (2014) 16 Advances in Developing Human Resources at 450.

107 Giffney (n 1) 5.

$108 \mathrm{~K}$ Wiredu 'Conceptual decolonisation as an imperative in contemporary African philosophy: Some personal reflections' (2002) 36 Rue Descartes at 54.

109 SJ Ndlovu-Gatsheni 'Decoloniality as the future of Africa' (2015) 13 History Compass at 488, 485-496; Wiredu (n 108) 55. 
colonial presumptions from the minds of those who were once colonised. ${ }^{110}$ It critiques Eurocentric methods that were used to conceptualise identity and reinforce the idea of universalism. ${ }^{111}$ Wiredu and Serequeberhan believe that African societies overvalue what comes from the west thus, a generic western identity is perpetuated, sustained and conserved. ${ }^{\$ 12}$ I support the belief that individuals must dissociate themselves from coloniality and rationally focus on deconstructing the identities that have been imposed on them. By doing so, individuals will be able to self-reflect and decolonise knowledge, being and power that has limited their identity and sense of self. ${ }^{113}$ This intersects with queer theory in that, queer theory also focuses on removing the colonial constructs surrounding sexuality and challenging the universalist notion of queerness.

Moreover, decolonial and queer theories cannot ignore the influence and intersection of feminist theory. Feminist theory goes as far as challenging the notion that: 'man is a natural category, and woman exists only in relation to man'. ${ }^{114}$ Van Marle maintains that social context influences the way in which a person experiences their gender and sexual orientation. Thus, their experiences are products of socialisation and not their actual gender and sexual identities. ${ }^{115}$ This position clashes directly with the colonial position that gender and sexuality are social constructs. Hence, it is evident that feminist theory works against the dominant constructs and concepts in society. ${ }^{116}$ Additionally, this theory embodies the same disruptive and self-reflective spirit as queer and decolonial theory. ${ }^{117}$ Feminist and queer theories don't just sporadically intersect; they constantly intertwine and advance the same ideas. A separation of the two will slowly result in negative outcomes such as a lack of inclusion and societal change. Both theories interrogate sexuality and gender at an individual level, organisational level, and societal level. ${ }^{118}$ Essentially, it can be concluded that feminist theory creates an environment in which queer theory can thrive.

\subsection{Decolonial criticisms of the Civil Union Act}

As established above, the Civil Union Act was one of the mechanisms advancing the transformation of queerness in post-1994 South Africa. A specific focus will be placed on the Act, and not on the concepts of

110 Wiredu (n 108) 56.

111 T Serequeberhan 'African philosophy as the practice of resistance' (2009) 4 Journal of Philosophy: A Cross Disciplinary Inquiry at 46.

112 Wiredu (n 108) 54; Serequeberhan (n 111) 49.

113 W Mignolo 'A manifesto' (2011) 26 Transmodernity at 49.

114 Gedro \& Mizzi (n 106) 447.

115 Van Marle \& Bonthuys (n 14) 22.

116 B Hooks Feminism is for everybody: Passionate politics (2000) 58.

117 Van Marle \& Bonthuys (n 14) 22.

118 Van Marle \& Bonthuys (n 14) 24. 
transformative constitutionalism and adjudication. This is due to the fact that these concepts dealt with the decriminalisation of queer identity and essentially set the foundation for transformation or decolonisation. ${ }^{119}$ As a result, the approach thereafter had to ensure the best outcomes for queer people and their identities.

Based on the context established in this essay, it can be asserted that the Civil Union Act never achieved sufficient transformation and decolonisation of queerness. First, the Act can be seen as a concession to colonialism because it incorporates the same christian-western values found in the Marriage Act. In addition to this, the inclusion of section 6 is a clear indication of the governments reluctancy to abandon homophobic and traditional beliefs. Second, the Act is set up in such a way that it is tailored towards individuals who identify as gay and lesbian. 120 Thirdly, the creation of a 'separate but equal' Act reinforces the harmful distinctions and differences between homosexual and heterosexual individuals. Lastly, the lack of cooperation between feminist and queer activists leads to isolationism and minimal advantages for each group. ${ }^{121}$

The set up and contents of the Act do not align with the principles in queer, feminist and decolonial theories. In order to successfully decolonise queerness and with specific regard to these theories, the Act needed to disidentify from colonial concepts perpetuated by religious and government institutions. Moreover, the Act needed to question the structure of identities and in some way disturb identities; not define them. ${ }^{122}$ Thus, the positionality of queerness and the universalist notion of queerness was never questioned. The inevitable conclusion is that: the Act did not achieve decolonisation of queerness because it assimilated to the western construct of marriage and it failed to deconstruct the ideology that harms so many queer individuals.

Apart from the above-mentioned criticisms, same-sex marriage legislation can be seen as problematic because it does not represent, nor does it extend to the complexities we see on the spectrum of identities. Thus, I can argue that it may not be for all queer people because it favours individuals who identify within the binary of gender and on the far ends (cis ends) of the spectrum of identity (it neglects individuals who show variations in identity). ${ }^{123}$ Legislation should avoid doing this because it runs the risk of equating queerness to

119 Refer back to pages $45-47$ of this Article (3.1 and 3.2 'Transformative constitutionalism' and 'Transformative adjudication').

120 TL Mccormick (n 102) https://theconversation.com/why-same-sex-marriage-isnot-the-ultimate-tool-for-queer-liberation-103702.

121 Bonthuys (n 21) 527.

122 Refer back to page 53-54 of this Article (4.1 'Queer, decolonial and feminist theories').

123 TL Mccormick (n 102) https://theconversation.com/why-same-sex-marriage-isnot-the-ultimate-tool-for-queer-liberation-103702. 
specific, isolated, LGBT-Q identities and their societally influenced gendered performances. ${ }^{124}$ Another approach that legislation should avoid taking is isolating the struggles and victories of marginalised groups. Race, gender and sexual orientation intersect to such a large degree that one cannot be preferentially treated over the other. ${ }^{125}$ The fight for gender and racial equality incorporated the fight for sexual orientation equality. Thus, legislation that focuses on singular identities and the prioritisation of one form of equality, is detrimental to all three movements because all three movements could benefit from each other. ${ }^{126}$ Feminist, decolonial and queer theories overlap with one another and they require a form of coalition activism that ensure the successful decolonisation of colonial constructs. ${ }^{127}$

Feminist, decolonial and queer theories aim to bring about reconstruction and decolonisation. They are the most effective tools that can be used to achieve this because they are identity based and they avoid all the harms that transformative law-making succumbs to.

\section{Conclusion}

In this essay I have investigated, criticised and re-contextualised the concept of queerness in South Africa. The current approach to queerness is transformative in nature but not necessarily 'queer'. I have demonstrated that there are shortfalls in the transformative mechanisms employed thus, an alternative is required. When dealing with queerness, you have to take into consideration the historical and identity based challenges of queer individuals. The transformative mechanisms considered the historical challenges of oppression but failed to incorporate the varying identities of queer individuals. Thus, my solution to this is queer theory and its intersections with decolonial and feminist theories. This approach considers all historical and identity challenges faced by the queer community and in doing so, decolonisation of queerness can occur which will implicitly incorporate the transformation of queerness as well.

Same-sex marriage is not the path to queer liberation as it merely transforms the institution it exists in - not the identities that exist in it. The underlying question then becomes: what is the queer concept of marriage? My answer is - nothing. I argue this because the most powerful opposition to marriage is not getting married at all. Queer individuals have placed an overvaluation on the concept of marriage and it has caused them to forget what it means to be 'queer'. We

124 Bonthuys (n 21) 527.

125 Giffney (n 1) 5; Van Marle \& Bonthuys (n 14) 23.

126 Van Marle \& Bonthuys (n 14) 23.

127 Refer back to page 53-54 of this Article (4.1 'Queer, decolonial and feminist theories'). 
need to reconstruct our identities and ensure that our concept of queerness is devoid of any western and colonial constructs that might limit us. Only then, can queerness truly be decolonised. 


\section{THE EASY WAY OUT? CONSTITUTIONAL AVOIDANCE AND ITS IMPACT ON HUMAN RIGHT ENFORCEMENT IN BOTSWANA}

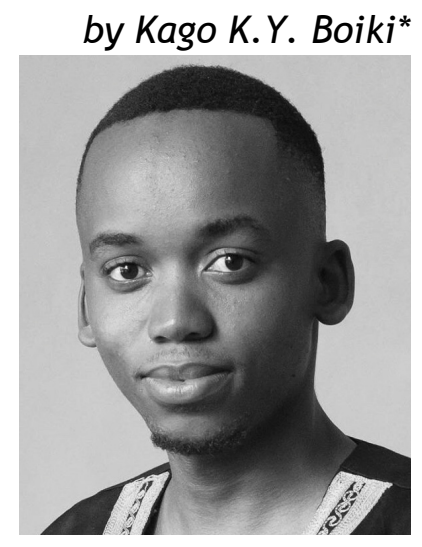

\section{Introduction}

Injustices occasioned by one person or entity on another can be remedied through the justice system. Parties who seek justice may approach courts of law to seek relief. However, when dealing with constitutional claims a more robust system exists in guiding litigants on procedure and possible remedies. Whether the courts allow for such claims and remedies however is still highly contentious matter, given the various doctrines the courts have adopted when dealing with constitutional matters.

Chief Justice Marshall once remarked: 'It is emphatically the province and duty of the judiciary to say what the law is.' 1 This proposition is all well and good, but it must be remembered that it is the province and duty of the legislature to say what the law should be. The limitations, sometimes self-imposed on the powers of any arm of government, especially the judiciary, have seen to have unmistakable consequences.

* LLB (University of Botswana), PGCert Risk Management, LLM Candidate (International Trade and Investment Law at the University of Pretoria) Attorney of Law admitted to the Bar (Botswana) Notary Public and Conveyancer. This article is aimed at promoting a critical analysis of the methods employed by the courts in executing their mandate.

1 Marbury v Madison 5 US (1 Cranch) 137 (1803) Chief Justice John Marshall. 
This article seeks to examine the doctrine of constitutional avoidance and assess whether it has had an impact on the protection of Human Rights in Botswana through the courts. This article will begin with the definition the doctrine of constitutional avoidance. This will be followed by an overview of Botswana's constitution and its Human Rights framework. The article will then go on to discuss the application of constitutional avoidance in Botswana, highlighting some case law that has been instrumental in the development of the doctrine of constitutional avoidance.

\section{Constitutional avoidance}

As a concept applied in the courts, the constitutional avoidance doctrine is a doctrine of statutory construction that states that 'when the validity of an act ... is drawn into question, and even if a serious doubt of constitutionality is raised ... the court will first ascertain whether a construction of the statute or any other is fairly possible by which the question may be avoided. ${ }^{2}$ It is courtesy of this definition that the concept has been afforded life over the decades. The doctrine effectively allows for the courts to avoid resolving serious constitutional disputes and issues by adopting even the narrowest interpretation of a statute.

The doctrine has been thoroughly examined in more developed nations, with jurisprudence which is rich in human right protections, which extend as far as socio- economic rights. ${ }^{3}$ The United States of America (USA) has been one of these nations, with its implementation leaving a lasting impact on the jurisprudence and the effectiveness of their federal judicial system. ${ }^{4}$ Within the Roman Dutch common law jurisdictions, it has been stated as the court's opinion that, the rules of avoidance were applicable at any stage as they are deeply entrenched in precedent. ${ }^{5}$ Furthermore, it has been said that the avoidance doctrine provides the courts with a method of preserving constitutional values without making unnecessary binding constitutional decisions. ${ }^{6}$ Should the courts be prone to lean towards

2 Ashwander $v$ Tennessee Valley Authority, 297 US at 288 (1936), (Brandeis, J, concurring).

3 J Dugard 'Beyond blue moonlight: The implications of judicial avoidance in relation to the provision of alternative housing' (2014) 5 Constitutional Court Review at 267.

4 MH Redish \& KL Drizin 'Constitutional federalism and judicial review: The role of textual analysis' (1987) 1 NYUL REV at 15.

5 Swaziland High Court, Vide Jerry Nhlapo and 24 others v Lucky Howe NO (in his capacity as Liquidator of [VIF] Limited in Liquidation). See also Civil Appeal No 37/07, Daniel Didabantu Khumalo v The Attorney General; Civil Appeal 31/2010, Lomvula Hlophe (on behalf of Acting Chief Ntsetselelo Maziya v Office In-Charge, Big Bend Correctional Institution) and 4 Others, Civil Case 2799/08.

6 RW Scheef 'Temporal dynamics in statutory interpretation: Courts, Congress, and the Canon of constitutional avoidance' (2002) University of Pittsburgh Law Review at 558-560 
making constitutional declarations, they run the risk of rewriting statute and possibly leaving a lacuna in the legislation. This is an obvious consequence should the challenged legislation be declared unconstitutional and thereby nullified, or even failing in totality to protect and preserve the constitutional norms at stake. It is arguable that the continued use of the doctrine allows for manipulation of the court system, in order to achieve desirable political outcomes, where a more favoured interpretative technique would lead to unfavourable results. This would in essence imply the incapability of the courts to establish a proper balance in implementing the doctrine. In other words, the courts' application of the doctrine would be grossly misguided by the eagerness of some jurists to make such declarations.

The Honourable Justices Annandale, Mabuza and Mamba JJ of eSwatini, justified the continued use of the doctrine, attributing it to the courts prudential desire not needlessly reach constitutional determinations in its decision. ${ }^{8}$ The court outlined the necessity of its use in adjudication of constitutional matters, and through this perspective, the use of the doctrine can be viewed as an exercise of judicial restraint. ${ }^{9}$ The question therefore arises whether it is prudent for a qualified judicial body to be willing to publicly abstain from fulfilling its mandate, which can be argued to be amongst other things, making constitutional pronouncements, and restraining itself through a self-imposed doctrine from fulfilling such mandate?

\section{Botswana's Constitution}

The Constitution of Botswana, has been credited for its promotion of democracy and affording all citizens equal rights. ${ }^{10}$ This is partly due to it having been able to maintain a stable, open and transparent democracy since independence. ${ }^{11}$ In its interpretation, it is abundantly clear that the framers of the constitution intended on the ensured protection of all human rights. ${ }^{12}$ Although socio-economic rights amongst others were excluded from explicit protection by the drafters at the time, this could have partly been due to the probable ignorance of the significance of the importance of such rights at the time. Socio-economic rights have been read into existence through a

7 Rust v Sullivan, 500 US 173, 204-05 (1990) (Blackmun, J, dissenting).

8 Nombuyiselo Sihlongonyane v Mholi Joseph Sihlongonyane (470/2013A) (2013) SZHC 144

9 As above.

10 Constitution of the Republic of Botswana Cap 0000 of 1966. See also Human Rights in Botswana, Ditswanelo, (2007).

11 CM Fombad 'Protecting constitutional values in Africa: a comparison of Botswana and Cameroon' (2003) 36(1) The Comparative and International Law Journal of Southern Africa at 83-105.

12 Diau v Botswana Building Society 2003 (2) BLR 409 (IC). 
broad interpretation of the civil and political rights provided for in the constitution. 13

As one of the three arms of government, the judiciary is undoubtedly the arm of government tasked with the protection of such rights as guaranteed in the constitution, through its interpretation and enforcement. The judiciary has been responsible for the judicial enforcement of socio-economic rights and has done so with satisfactory effectiveness and independence although, some of its decisions are questionable following applications by litigants. ${ }^{14}$

In a number of recent landmark decisions alongside other interpretative techniques, the courts have adopted a doctrine of constitutional avoidance in their approach to determine cases with major constitutional implications. This trend was seemingly first established in the recent Attorney General $v$ Thuto Rammoge and 19 Others case (hereafter 'LEGABIBO') judgment, which was followed by the Tapela v Attorney General (hereafter 'ARV') case. ${ }^{15}$

Historically, constitutional avoidance was understood to be a method of resolving interpretive ambiguities: if there are two equally plausible readings of a statute, and one of them raises constitutional concerns, judges readily chose the one which did not question the constitution. ${ }^{16}$ Several decisions of the High Court and Court of Appeal have been seen to have been decided on this doctrine. These courts have effectively shown their reluctance to bind the jurisprudence to precedents, which effectively make final determinations on highly contested constitutional questions as was shown in the cases discussed later in this article. In the USA, where the principle of constitutional avoidance is used to safeguard not only constitutional integrity but also federalism, jurists, scholars, and practitioners have criticised decisions made through the adoption of such a doctrine, claiming that they amount to unaccountable judicial conduct and prevent the growth of constitutional jurisprudence. ${ }^{17}$

Although it is clear that the doctrine adopted by the courts is not favoured by human rights activists, scholars and jurists, its continued implementation raises a series of concerns such as the inadequate protection of the fundamental rights of individuals and the failure of the courts to fulfil its mandate when issues of human rights protection

13 BR Dinokopila 'The justiciability of socio-economic rights in Botswana' 57(1) Journal of African Law at 108-125.

14 RA Kumar 'Constitutional rights and judicial activism: Bridging the gaps in Botswana' in E Quansah and W Binchy (eds) The Judicial Protection of Human Rights in Botswana (2009) 121.

15 Court of Appeal Civil Case No CACGB-128-14 delivered 16 March 2016, Court of Appeal Civil Case No CACGB-096-14; Attorney General and Others v Mwale, Court of Appeal Civil Case No CACGB-076-15 delivered 26 August 2015.

16 A Nolan 'The doctrine of constitutional avoidance: A legal overview' (2014) 2.

17 WK Kelley ‘Avoiding constitutional questions as a three-branch problem' (2001) 86 Cornell Law Review 846-60. 
are questioned. The implications of adopting the doctrine of constitutional avoidance in the courts may have a direct correlation with the protection of human rights in Botswana. This thereby brings into question the obligations of the judicial arm of government and questions whether they have been fulfilled through the adaptation of this doctrine; and also, whether the continued implementation of the doctrine amounts to responsible judicial activism.

\section{An overview of the protection of human rights in Botswana}

Civil and political rights guaranteed under the constitution are afforded to all individuals within Botswana's jurisdiction. It has been consistently argued and reported that Botswana has maintained a good human rights protection record relative to most African counterparts although, the constitution lacks in express provisions for socio-economic rights. ${ }^{18}$

\subsection{Constitutional provisions}

The constitution makes provision, under chapter II, for the preservation and protection of civil and political rights also referred to as first generation rights. ${ }^{19}$ After over fifty years of its application, the Constitution still reflects greatly on its originating influences such as, the European Convention on Human Rights, and is steadfast in so far as remaining one of the very few African constitutions that has not had an amendment of its bill of rights since enactment is concerned. ${ }^{20}$ Sections 3 to 15 of the Constitution provide for most of the civil and political rights. Section 3 is the umbrella provision for the rights embodied in chapter II. ${ }^{21}$ Anti- discrimination sentiments in the enjoyment of basic human rights are clearly expressed in the constitution as per the grounds so listed.

Botswana is party to several international and regional human rights instruments. These include but are not limited to, the International Covenant on Civil and Political Rights (ICCPR), the Convention on the Elimination of All Forms of Discrimination against Women (CEDAW) and the African Charter on Human and Peoples' Rights (ACHPR).

However, due to the fact that Botswana is a dualist state in its implementation and application of international instruments, treaty

18 Kumar (n 14) 121

19 Constitution of the Republic of Botswana (n 10) Chapter 2.

20 Dinokopila (n 13) 110.

21 EK Quansah 'Law, religion and human rights in Botswana' (2008) 8/2 African Human Rights Journal at 491. 
provisions do not become part of the laws of Botswana unless, specifically incorporated into the laws of Botswana through an act of Parliament. ${ }^{22}$

The Constitution under section 18, allows for the High Court of Botswana, to make determinations on the protection of rights entrenched under the Constitution. Therefore, for any alleged violations of sections 2 through 16 of the constitution, the aggrieved individual(s) may apply to the said court for redress. The court is further endowed with inherent jurisdiction in all instances of human rights violations which are brought under the said section 18. Should litigants be unhappy with decisions of the High Court they may appeal to the Court of Appeal thus, making it the final court within the jurisdiction which is capable of making determinations on Human rights issues.

The national case law is rife with constitutional questions that the Court has avoided whilst applying the doctrine, only to later on hold in favour of the constitutional challenge, when forced to confront the question under a different statute, where the constitutional challenge would succeed. It is in that light that the conduct of the courts, in so far as their interpretive techniques are concerned, are given significance, as they have an inevitably lasting impact on the human rights environment within the country. The courts are also seen as the most effective remedy in a peaceful democracy and the neglect of this role can only lead to anarchy. The doctrine of constitutional avoidance has been adopted by the courts and has left inescapable consequences, the most significant of them being that major constitutional questions remain unanswered, thereby allowing for the perpetuation, in some instances, of human right violations. The courts have further missed various opportunities in reshaping the human rights perspective within the country leading to a never-ending cycle of constitutional challenges over very similar issues, which were distinguished and manipulated by the courts so as not to receive constitutional attention and challenges by the candidates.

\section{Constitutional avoidance in Botswana}

Recently the decisions of the Botswana courts of record, the Court of Appeal and the High Court are of considerable interest in the growth of our constitutional law jurisprudence, alongside the constitution making and interpretation mechanisms within the jurisdiction. ${ }^{23}$ However, in reaching their decisions, it is arguable that the courts

22 Good v The Attorney-General (2) 2005 (2) BLR 337 (CA) 354.

23 The Attorney General $v$ Rammode and Others No CACGB-128-14. See also The Attorney General and Others $\vee$ Tapela and Others No MAHGB-000057-14, CACGB096-14. 
made determinations which were underwhelming in so far as making constitutional determinations is concerned, as the courts clearly and expressly adopted the doctrine of constitutional avoidance in their final judgements.

\subsection{History of avoidance in Botswana}

Following Motshegwa Busang $v$ The State, there was an indication of the adoption of the doctrine of constitutional avoidance in Botswana. ${ }^{24}$ The court reached the decision to adopt the doctrine in order to establish its position and ultimate desire to prevent itself from appearing to be posturing its power, thereby ultimately appearing as an opponent of the government. The court thereby chose to abandon its traditionally accepted role as a watchdog of justice in ordinary litigation. 25

When tackling the issue of failing to address constitutional questions raised during litigation, Presiding Judge His Lordship Maisels $\mathrm{P}$, in referring to precedent from the American jurisdiction stated:

In the United States of America, the Supreme Court has refused to pronounce decisions upon constitutional questions unless it has been absolutely compelled to do so in the particular case. Its reason for so doing is to minimize the possibility of conflict between it and the executive or the legislature ... With respect, I consider this to be the proper approach and one that this court should follow ... ${ }^{26}$

Although the learned justice chose not to elaborate any further on the issue in this instance, the decision left an impact on the judicial structure as it was the first indication of the adoption of a reasonable rationale for adoption of the doctrine of constitutional avoidance.

In this very sensitive era of our jurisprudence where the protection and enforcement of rights has taken great strides, neighbouring nations, in adopting the same doctrine, found fresh reason to apply the doctrine of constitutional avoidance. This position taken by the courts protected the peace between the arms of government and ensured that neither was seen to be overstepping and

24 Criminal Appeal of 1981 at 15- A complainant before a lower customary court was from an aggrieved person in terms of section 37 of the Customary Court (Act No 1 of 2006) Cap 04:05, for the purpose of Appeal to the Higher Customary Court. The reception of evidence in such an appeal is not an irregularity. The appellant was acquitted by a Subordinate Tribal Authority on a charge of stock theft. The complainant appealed to the Bamangwato Senior Customary Court and after a full re-hearing of the evidence the appellant was convicted.

25 A van Blerk 'The Botswana Court of Appeal: A policy of avoidance' (1985) 18(3) The Comparative and International Law Journal of Southern Africa at 385-395

26 This statement of the principle first appeared in Crowell $v$ Benson, 285 US 22, 62 (1932) (per Hughes, CJ). Mr Justice Frankfurter has related the principle to the 'case and controversy' rule, though conceding that the defect is not jurisdictional. See United States v CIO, 335 US 106, 126 (1948) (concurring opinion); cf. Cohens v Virginia, 6 Wheat. 264, 441 (US 1821). 
undoing the work of the other. Through the case of $S v$ Marwane, a South African court showcased its willingness to invalidate the provisions statue following determinations of unconstitutionality. ${ }^{27}$ When commenting on this decision in the later decision of Smith $v$ Attorney-General, Chief Justice Heimstra stated:

The Marwane case is a typical example of over-eager invalidation leaving a large lacuna in a country's legislation as it stood at the time of the relevant proceedings. The good was thrown out with the bad although the bad played no part in the relevant decision ... A Bill of Rights is not a wide-open door to the invalidation of legislation." 28

The learned Chief Justice continued to present his view on the delicate balancing process which is required in this dimension of constitutionalism. This being done in order to avoid resentment of the judiciary by the legislature as a result of an overzealous judiciary, which was quick to nullify statutes and in effect nullifying Acts of the legislature which were not in any stretch of the imagination easy to implement. He stated:

The Court helps to shape the Declaration of Human Rights with great deference to the Legislature. A Court which is over-active in striking down legislation can destroy the exalted instrument it is trying to bring to life, it can incur the resentment of the Legislature and cause the Declaration, which was meant to be a charter of freedom to become a clog upon the wheels of government. That must be avoided for the sake of the Constitution itself and for the sake of the statute of Parliament as the highest law-making forum of the nation. ${ }^{29}$

It was through these decisions that a clear intention to cement the doctrine of constitutional avoidance was clearly illustrated in the South African lower courts, although the constitutional court has never shown any intention to shy away from its responsibility in that regard. This stance would thereby be a decision which would have consequence on Botswana's courts as they borrowed jurisprudence from their neighbours as persuasive precedent.

\subsection{The first landmark decision}

Similar to many other legal principles and doctrines, the existence of the doctrine of constitutional avoidance truly came to light in Botswana in the land mark decision of State $v$ Petrus and Selaola. ${ }^{30}$

2719823 SA 717 (A), split bench 7-4. In the particular instance provisions of the South African Terrorism Act were nullified even though they fell under the protection of the same constitution as the new constitution expressly declared that only post-constitutional law would be subject to being nullified and declared unconstitutional.

2819841 SA 196 (B) of 199 to 200. See also van Blerk (n 25) at 385-395.

29 Smith v Attorney- General, Bophuthatswana [1984] 1 SA 176 (B)

30 Criminal Appeal 34 of 1983. 
This case was brought to light following the two accused persons being convicted by a senior magistrate in Francistown, in December 1982, for the offence of housebreaking and theft in contravention of section 305(1)(a) of the Botswana Penal Code. ${ }^{31}$ Two months prior to their conviction, in October, section 305(1)(a) had been amended. ${ }^{32}$ The amendments to the act fundamentally altered the prescribed sentences for the offences and the execution of the sentences. ${ }^{33}$ In accordance with the amended legislation the accused were each sentenced to three years' imprisonment and to corporal punishment as described in, the new section 301(3). On review, Hannah $\mathrm{J}$ in the High Court, suspended two years of the imprisonment but reserved for the Court of Appeal issues for determination related to the interpretation of the amended sections in the Penal Code and the mandatory nature of the sentences to be imposed. ${ }^{34}$ The accused person's attorneys then made an application alleging the prescribed sentence contravened the constitution which protects against torture and inhumane treatment.

The court then reconstituted to ensure that an adequate quorum was presented in dealing with the constitutional challenges raised. Following the mutual consent of the parties, the court then prepared to hear arguments and make determinations related to the questions posed to it.

The attack on the constitutionality of section 301(3) was directed at two aspects: the provision that the corporal punishment be administered in instalments and the provision that it be administered in the traditional manner, with traditional instruments, as had been the norm.

With due regard and in respect of the first aspect, the Court of Appeal was clear in its finding that the provision for repeated and delayed infliction of strokes flew in the face of section 7(1) of the constitution. This determination was based on the clear evidence of mental anguish of anticipated violence which had been viewed by varying jurisdictions as an inhumane and degrading punishment. ${ }^{35}$

31 Penal Code had come into effect as a Proclamation of the Bechuanaland Protectorate in 1964.

32 Botswana Penal Code Act 20 of 1982.

33 Amendments to the Penal code were closely followed by amendments to the Criminal Procedure and Evidence Act (By Act 21 of 1982, Act originated as a proclamation of Bechuanaland Protectorate, in 1938) which in essence prescribed methods of executing said corporal punishment which were inclusive of its administration in instalments. (Section 301(3) of Criminal Procedure and Evidence Act).

34 State $v$ Petrus and Selaola (review case 51 of 1983). See also Petrus and Another $\checkmark$ The State 1984 BLR 14 (CA) para 18.

35 Tyrer $v$ United Kingdom (1978) 2 EHHR 1 (the Isle of Man). 
The court however changed its tone with respect to the second challenge, as it proved to be less equivocal in respect of the second aspect; on whether the infliction of strokes in the traditional manner, with a traditional instrument was in conflict of section 7 of the constitution. The question was not without considerable importance and weight as any declaration by the court that such method of whipping was unconstitutional would have meant that the legislature could not re-enact it to retain a traditional, pre-constitutional form of punishment, the imposition of which was lawful in terms of the derogatory clause, section 7(2).

This landmark case had gained interest as being the first in Southern Africa in which corporal punishment had been challenged on the ground that it is degrading or inhumane. ${ }^{36}$ The decision however showcased the court openly holding back in giving a teleological interpretation to the constitution on two issues: first, the question whether the provision that corporal punishment be administered in traditional manner with traditional instrument was in conflict with section 7 of the constitution and, second, the question whether the imposition of corporal punishment per se or corporal punishment, in addition to a term of imprisonment was in conflict with section 7 of the constitution.

An assessment of the case however, shows to be fair as it cannot be said that the courts' chosen approach is without benefits. It has been shown that the court would have been critiqued for abusing its powers had it made determinations on matters that had not been brought before it. The absence of a final determination however, leaves room hopefully for the courts to remedy the situation should the question be raised again.

\subsection{The judicial position}

When it comes to the powers of the judiciary, the conventional view is that this wing of the government interprets the Constitution and other laws, and applies them. While deciding a particular case, the judge has to interpret the relevant law and apply the same to the facts, in order to reach a verdict. A specific legal provision can be interpreted in different ways. It may also happen that the same law is interpreted by different judges in different ways. While some judges stick to the plain text, others try to decipher the intent of the law and apply it accordingly. Others however, seek to rely on precedents set by their predecessors.

The application of the doctrine of constitutional avoidance has recently been used in land mark decisions by the High Court and Court 
of Appeal in establishing a precedent on issues of constitutional significance. The recent decision of Attorney General and Others $v$ Tapela and Others, popularly known as the ARV case, set a precedent in favour of the application of the doctrine of constitutional avoidance in a rather elaborative fashion. ${ }^{37}$

This case emanated from a 2004 internal directive by Botswana's Secretary of Health, which was circulated to public medical facilities informing them of a Presidential Directive authorising 'provision of free treatment to non-citizen prisoners suffering from ailments other than AIDS.' The two prisoners who were both diagnosed as HIVpositive in prison were denied ARV treatment although their physical conditions met the treatment criteria under the government's Treatment Guidelines. The government denied them ARV treatment as per its policy on the basis that they were not citizens.

HIV-positive non-citizen prisoners filed lawsuits through their representatives challenging this directive after being denied free Anti-Retroviral Therapy (ARVs). They argued that the refusal to provide ARVs contravened the National Policy on HIV and AIDS, which mandated the government to provide basic health care to prisoners, and that it violated the rights to life and non-discrimination, and constituted inhuman and degrading treatment under sections 4, 3,15 and 7 of the Constitution. The HIV-positive prisoners and the Botswana Network on Law and HIV/AIDS (BONELA) further challenged the Botswana government's refusal to cover the cost of ARVs for noncitizen prisoners. The case was consolidated with an appeal against contempt proceedings through which another HIV-positive non-citizen prisoner sought to enforce the lower court's order that, non-citizens meeting the treatment criteria be provided with ARVs.

\subsection{The High Court decision}

When deciding the matter following the conclusion of procedural disputes, the court began by affirming the science of ARV treatment. In the course of his judgment, Sechele $\mathrm{J}$ made several findings on the evidence that affirm the rationality and importance of ARV treatment. It held that ARVs are 'not only a medical necessity but a life-saving therapy the withholding of which will take away the constitutionally guaranteed right to life., 38 The Court further set an important precedent in pointing out the state's obligations towards prisoners, regardless of their citizenship status. In line with international standards, the Court held that inmates retain the residuum of their human rights when their liberty is taken away. 
The Court further held that the Prisons Act (hereafter 'the Prisons Act') imposes upon prison authorities the obligation to not only take measures to 'restore the health of prisoners' but also to 'prevent the spread of disease. ${ }^{39}$ This is a valuable interpretation to insist that preventative measures that vital, even though their use would effectively be seen as an admission by the prison officials that sexual activities occur in their facilities. The Court continued to hold that the limit on the rights of non-citizens under the Constitution is only justifiable if it is reasonable in a democratic society and is in the public interest. The Court held that it could never be justifiable in a democratic society to deprive a group of persons of life-saving treatment as such deprivation would result in them becoming more infectious to others thereby risking the enjoyments of their rights.

The court in this instance was unrelenting and clear in applying the protective provisions of the constitution in protecting the rights of the individuals concerned. The judgment was valuable for future public interest litigation in Botswana and set an important precedent in establishing a human rights-based approach to the treatment of foreigners and prisoners. However, in the appeal of the matter the court in that instance took a varying approach.

\subsection{Avoidance in action at the Court of Appeal}

In making its ruling, the court, upheld parts of the High Court decision. ${ }^{40}$ The court however rejected the government's arguments on permissible discrimination, the violation of separation of power principles and resource constraints. First, the Court found that because the directive was not a law and because the Prisons Act and Regulations forbid discrimination, the directive was not 'reasonably justifiable' in the public interest or to protect the rights of others. ${ }^{41}$

With reference to the lower court's decision which had rested on constitutional grounds, the Court of Appeal cautioned against reading socio-economic rights into the Botswana Constitution which does not guarantee such rights, including the right to health. Accordingly, the court narrowly limited its holding to non-citizen prisoners being entitled to medical treatment due to the provisions of the Prisons Acts rather than reading a right to health for all HIV-positive foreign residents.

39 Prisons Act (Cap 21:03) (Act No 28 of 1979).

40 Attorney General and Others $v$ Tapela and Others, Court of Appeal Civil Case No CACGB-096-14. See also Attorney General and Others v Mwale, Court of Appeal Civil Case No. CACGB-076-15.

41 Prisons Act (Cap 21:03) (Act No. 28 of 1979). 
Kirby JP in stressing the importance of constitutional determinations stressed that constitutional cases are of great moment and are thus brought only in exceptional cases, since:

... the vast majority of disputes can be resolved by reference to the common law and to the statutes enacted by Parliament, and by review proceedings. It is for this reason that it has been consistently held, as $\mathrm{Mr}$ Marcus pointed out, that where a case can be determined without resorting to the Constitution, that is the route which should be followed. ${ }^{42}$

In Ramantele Vs Mmusi \& Others a full bench of the court of appeal had previously stated (per Lesetedi JA at para 41) that:

It is a well-recognized rule of decision-making that where it is possible to decide a case before the Court without having to decide a constitutional question, the Court must follow that approach. ${ }^{43}$

The learned justice had earlier made similar sentiments when at para 22 of the Ramantele case described the doctrine as 'a firm rule of practice', where the words of Kentridge AJ in Mhlungu's case were cited, namely,

I would lay it down as a general principle that where it is possible to decide a case, civil or criminal, without reaching a constitutional issue; that is the course which should be followed. ${ }^{44}$

From an assessment of the ARV case, it was thereby conclusive from the decision of the court, alongside previous determinations of the court that, should any applications or any subsequent appeals arise from the protective provisions of the constitution, these matters could, in future, be determined by applying and interpreting the provisions of any other statute which was relevant to the circumstances. In the particular instance, those of the Prisons Act and the Regulations made thereunder. As a result, there would be no need to address the constitutional questions raised alongside the discussion and findings on these by the judges $a$ quo. Although interesting and pertinent questions were asked of the court, any attempt to address them would be rendered obiter in nature, as the highest court within the jurisdiction refused to recognise and reemphasise the constitutional determinations of the court a quo.

The concept of constitution avoidance undoubtedly presents itself as one of the self-imposed limitations by the judiciary hence, a thorough examination of the said doctrine and its impact on various aspects of law is essential in the study of the law.

42 Court of Appeal Civil case No CACGB-096-14 Para 37.

43 Court of Appeal Botswana case No CACGB-104-12.

44 Mhlungu \& Others 1995 (3) SA 867 (CC) at 895E. See also Ramantele $v$ Mmusi \& Others Court of Appeal Botswana case No CACGB-104-12. 


\section{Room for improvement}

It has been established from the decisions of the courts that they are rather unable to avoid new constitutional danger zones due to the progression of the jurisprudence on human rights and the emergence of new issues to be addressed by the courts. The courts are thereby unsurprisingly forced to create 'constitutional danger zones' when implementing interpretive techniques such as the doctrine in question, which at times leave more questions unanswered.

The savvy avoidance doctrine has allowed the Court on numerous occasions to avoid the effects of its own shifts in constitutional theory; to confront the fact that a statutory problem in such a case is the Court's own creation. The doctrine has been seen to strengthen the Court's ability to sidestep politically controversial decisions, but consequently weaken the intellectual integrity and transparency of the Court's analysis. As an extended consequence, this weakens the political process in so far as constitutional decisions bearing political weight and affecting the democratic landscape is concerned.

The avoidance canon should be applied only when the Court has exhausted other available tools of statutory construction and the reading goes beyond a vague, undefined danger zone into the clearly marked red zone of unconstitutional interpretations, which would distort the legislation in place and the intentions of the only arm of government which enacts legislation. If the Court uses the doctrine as one of last resort, general concerns over the 'delicate and final nature of judicial decisions' would undoubtedly be satisfied. As a doctrine of last resort, the canon still protects statutes and their provisions from invalidation, while also avoiding the reading into existence of socioeconomic rights which were never envisioned by the original drafters of the constitution. The doctrine further protects the jurisprudence from unnecessary declarations with constitutional implications, where other legislation exists to address the issues. When there is doubt, the presumption of constitutionality would apply to also protect the legislation from invalidation. Both tools of construction and interpretation would have their place in application rather than clashing with one another.

Avoiding the avoidance doctrine in this manner also increases the judicial dialogue on constitutional issues. When lower courts invoke the canon to avoid a constitutional issue, it thwarts lower court examination of the constitutional issue and prevents the highest court from benefiting from the lower courts' opinions on the merits of a constitutional claim, thereby undermining the development of the law prior to the highest court weighing in on the issue. Building a judicial dialogue among the judiciary will also alert the legislature of potential problems with its legislation, by giving the legislature an opportunity to weigh in on the matter and clarify its intent. Thus, 
before an issue gets to the court of last resort, the legislature will more likely be aware of the difficulties with a given interpretation and will be capable of responding prior to the Court considering the issue. As a result, leaving use of the avoidance doctrine to courts of last resort would positively increase the dialogue between the judiciary and the legislature.

In order to establish and truly remedy the undesirable aspects of the doctrine of constitutional avoidance, the courts are at liberty to abandon its continued practice or rather adopt more proactive interpretative techniques as was seen in the high court decision in the ARV case. ${ }^{45}$ For there to be a meaningful progression and development in the jurisprudence of the jurisdiction, there is need for clarity in the normative framework and rules of application of section 18 of the Constitution.

Judges have sworn to bring justice to the country, this does not change based on when the judiciary undertakes to uphold human rights by all means available to them. It allows them to do what they see fit, within reasonable limits of course. The instilled trust that is placed in the judicial system and its judgments should be grounds enough for it to stand firm in approaches that do not seem to cower behind application of interpretive doctrines which may be viewed as an abdication of their judicial functions.

\section{Conclusion}

In the interests of preserving judicial independence, the judiciary should be mindful of its traditional role and careful not to step on legislative toes. Regardless of the relative merits and demerits of constitutional avoidance as a judicial strategy and philosophy, the doctrine of constitutional avoidance appears to have a broad following within our jurisdiction.

To the extent that the legislature "punts" to the Court on an issue of constitutional importance, the constitutional avoidance doctrines raises the possibility that the Court may send the "political football" back to the democratic arena and force the political branches to resolve major constitutional questions on their own. In this sense, the avoidance doctrine may be a means of reinforcing and correcting legislative intransigence on major legal issues. However, this may be a risky approach as the appropriate or desired legislative response is not guaranteed especially with due regard of the stream of constitutional challenges the court is faced with regularly. As demonstrated by the criticisms of the avoidance doctrine, the Court's unwillingness to answer major constitutional questions may be 
detrimental as the doctrine often does not operate as a comprehensive or cohesive theory to statutory interpretation. The doctrine of constitutional avoidance cannot be permissible simply to avoid answering difficult moral, social, and political questions altogether as that may amount to failing to execute their mandate. 


\section{LOOKING TO LITERATURE FOR TRANSFORMATION}

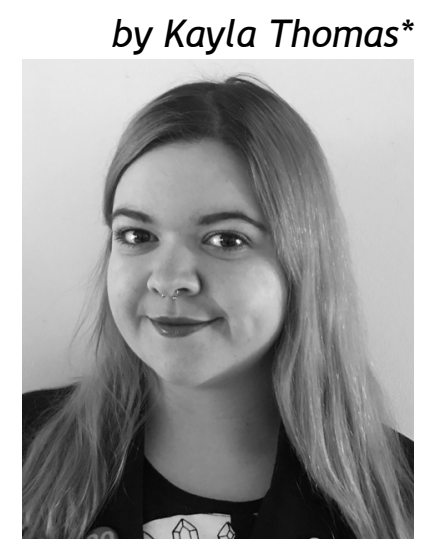

'And poetry perhaps is born again' - Shalom Freedman

\section{Introduction}

Law is a social discipline that concerns every aspect of the human experience. Legal education prepares law students for a career in this social discipline and should thus produce socially minded professionals that consider and value the vast spectrum of the human experience. ${ }^{1}$ In the post-1994 context of South African legal education, transformation of the legal syllabus is required to ensure a general jurisprudential approach to law that gives value and acknowledgment to the multitude of experiences, perspectives and voices that make up the human experience which is central to the law. This is to ensure substantive justice and an approach to law that values previously dismissed or devalued perspectives such as those of females, Africans and subjective and trans-disciplinary approaches to legal education. ${ }^{2}$

* Third year BA Law student majoring in English at the University of Pretoria. In this adaptation of a JUR 310 research essay, the role of diverse English literature as a part of a multidisciplinary post-1994 South African legal education is explored as central to creating morally and socially conscious legal professionals.

1 M Nussbaum 'Cultivating humanity in legal education' (2003) 70 The University of Chicago Law Review 270.

2 Y Waghid 'Knowledge Production and higher education transformation in South Africa: Towards reflexivity in university teaching, research and community service' (2002) 43 Higher Education 467. 
Law students at the University of Pretoria are required to take English literature courses as part of their legal education in specifically the LLB and BA Law programs. This contributes in part, to establishing a more inclusive jurisprudence and a legal education focussed on transformation. By including fields such as the humanities in the legal syllabus, assumed binaries of objective, legally relevant fields of knowledge versus subjective social sciences are blurred in favour of a non-dualistic approach to legal education. ${ }^{3}$ However, the limited inclusion of diverse perspectives - namely, African and female perspectives in African and female texts - stunts the transformative efforts of the Law Faculty, by exposing law students studying literature to predominantly Eurocentric and male texts. ${ }^{4}$

The English literature that is being taught to law students plays a role in shaping critical and ethically conscious lawyers, as well as in contributing to a transformative approach to legal education in post1994 South Africa by engaging with different perspectives. Value lies in engaging specifically with previously devalued perspectives in a substantive way. ${ }^{5}$ While limited progress has been made to include diverse and previously undervalued perspectives, a more inclusive English syllabus will produce more ethically conscious and humanistic law students and lawyers. ${ }^{6}$

Incorporating more literature of marginalised groups into the law syllabus in a non-hierarchical way will challenge and perhaps begin to dismantle the pre-democratic dominance of structural and psychological oppression, systems of patriarchy, and the black inferiority complex. ${ }^{7}$

\section{The role of English literature in legal education}

To evaluate the role of English literature in law and legal education, a discussion of general and restricted jurisprudence will be of value. Jurisprudence in this discussion being the critical evaluation of the interplay between legal consciousness and humanism with regard to educating moral legal professionals. Restricted jurisprudence is typically formalistic in nature and awards limited value or relevance

3 Nussbaum (n 1) 271. See also G Minda Postmodern legal movements: Law and jurisprudence at century's end (1995) 111.

4 University of Pretoria, Department of English ENG 110, 120, 210 and 220 study guides (2018).

$5 \quad$ Nussbaum (n 1) 271.

6 B Lindfors 'African literature teaching in South African University English Departments' (1996) 3 Alternation 6. See also M Aristodemou 'Studies in law and literature: directions and concerns' (1993) 22 Anglo-American Law Review 160.

$7 \mathrm{~K}$ van Marle \& E Bonthuys 'Feminist Theories and Concepts' in Albertyn, C \& Bonthuys, E (eds) Gender, law and justice (2007) 21. See also S Biko I write what I like: A selection of his writings (1978) 22. 
to what are perceived as 'other' perspectives, which have historically been overlooked or oppressed. 8 This negates the connected nature of all social disciplines and the law itself as a social discipline by focusing only on conventional legal education. ${ }^{9}$

General jurisprudence, in contrast, calls for a critical consciousness to be employed by legal professionals. ${ }^{10}$ This includes the Critical Legal Studies argument that law and legal education should include and utilise the multiple disciplines that the law is part of and relevant to. This includes the multi-disciplinary nature of law itself, with regard to relevant disciplines such as literature, politics and philosophy. ${ }^{11}$ The inclusion of diverse theoretical perspectives is what contributes to a general approach to jurisprudence and, in turn, to transformative legal culture in the Constitutional era. ${ }^{12}$

In educating law students in a post-1994 South Africa, tertiary institutions have the onus to transform higher education. ${ }^{13}$ This, in my view, can only be achieved by a thorough and substantive shift in knowledge production. This substantive shift cannot consist of a mere exposure to different fields of knowledge but should rather entail an engagement with and re-evaluation of 'different' and previously oppressed voices. These voices should furthermore be considered as equal to those of the Eurocentric and mostly male perspectives currently studied. ${ }^{14}$ This substantive shift of knowledge can furthermore be achieved through a trans-disciplinary approach wherein greater focus is awarded to the relationship between 'set' categories of the law that are considered objective, and literature that is considered liberal and subjective. ${ }^{15}$

The imposed classifications of certain knowledge as a commodity in being objective and thus assumed as rational, and other knowledge such as the arts as subjective, and thus inferior in validity, limits legal education to a restricted and formalistic syllabus of only formal legal and economic rules and application. ${ }^{16}$ By acknowledging and furthermore valuing the subjective, liberal and philosophical aspects of typically non-'legal' fields of study such as literature, law students are taught to incorporate different kinds of knowledge for their political philosophy of justice (2005) 3.

9 Waghid (n 2) 458.

10 Douzinas \& Gearey (n 8) 4.

11 A Mbembe 'At the centre of the knot' (2012) 38 Social Dynamics 8.

12 K Klare 'Legal culture and transformative constitutionalism' (1998) 14 South African Journal on Human Rights 150.

13 Waghid (n 2) 457.

14 University of Pretoria, Department of English ENG 110, 120, 210 and 220 study guides (2018).

15 Mbembe (n 11) 8.

16 Mbembe (n 11) 8. 
unique strengths and experiences that can enhance or enrich a law student's application of the law. ${ }^{17}$ By incorporating and interpreting different areas of knowledge in terms of one another, the law student is encouraged to understand humanity and society from as many varying perspectives as possible, so as to ensure an open minded, inclusive and ethically conscious approach to society and its workings in any legal problem. ${ }^{18}$

In promoting a general jurisprudential approach to legal education, English literature promotes, on a base and formal level, better reading, writing skills and analytical skills for law students. ${ }^{19}$ This is of course important for law students, but arguably a smaller aspect of literature's role in legal education when considering the role of literature in teaching and encouraging law students to value the human experience and the position of law in this experience. Maria Aristodemou argues that literature courses in legal education serve more to build ethical and humanistic lawyers that not only work for their society but are also active citizens in it, thus gaining insight into and an understanding of society as a vast and varying structure, and humanness as a value to be sought after in all disciplines. ${ }^{20}$ Literature exposes students to the experiences, history and voices of diverse people who hold different worldviews and addresses the dominant discourse of law to overlook humanistic values. ${ }^{21}$ In legal education this promotes consideration of people's lived experiences as portrayed in literature and prompts the evaluation and understanding of social and political factors that shape different aspects of society and the law.

In being a social concern that permeates all aspects of humanity and society, understanding and valuing the position of the human experience through literature encourages ethical and social sensitivity and empathy in law students. ${ }^{22}$ This is increasingly important in establishing a general approach to legal studies that incorporates diverse views and perspectives, as called for by critical legal studies arguments, to effectively work towards substantive justice. $^{23}$

Such diverse views arise from disciplines such as the humanities, with English literature as a core discipline within the humanities. Literature, and the study of it, teaches law students that humanity is

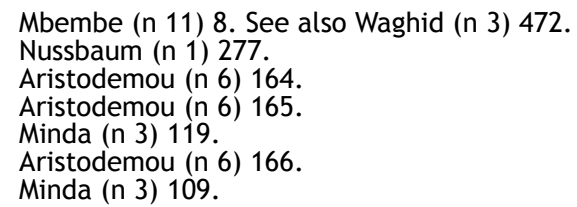


interconnected in varying ways and that the law is one of many components of this interconnectivity. ${ }^{24}$ In exposing law students, as future lawyers, to different and varying perspectives through literature produced by the voices of these perspectives, students broaden their understanding and appreciation of the perceived 'other' as an equally valuable and relevant aspect of the interconnected human experience. ${ }^{25}$ This results in what Martha Nussbaum labels the 'Socratic' lawyer in that they are ethical and open to their approach to and as part of society. ${ }^{26}$ Literature teaches law students to value, understand and empathise with the problems, experiences and voices of others of varying histories. ${ }^{27}$ This is a crucial and invaluable necessity to the pursuit of substantive and meaningful justice in our Constitutional era.

Furthermore, the inclusion of female and African texts in literature studies demonstrates to law students, through analysis, close reading and subjective interpretation, the value of feminine ways of thinking in the legal and literary field. ${ }^{28}$ The consideration of and value awarded to subjective and personal experiences of humanity by law students through the study of literature promotes ethically conscious lawyers that incorporate into their positions as citizens and humans, an understanding of other humans in their approach to the law and pursuit of justice. ${ }^{29}$ Understanding the humanity present in the law by understanding human beings and the rich and diverse different experiences of humanity fosters tolerance, empathy and insight in law students. ${ }^{30}$ This is turn will lead to ethical lawyers who promote further transformation in both society and the legal profession as an inseparable component of society. ${ }^{31}$

\section{Why and how transformation of legal education through a diverse English syllabus is important}

Simply including disciplines such as literature in the legal syllabus does little in terms of transformation in the Constitutional era. The Constitution calls for the 'heal[ing] [of] the divisions of the past' and this healing can only be done through substantive and meaningful change. ${ }^{32}$ Manganyi explains that substantive change can be achieved

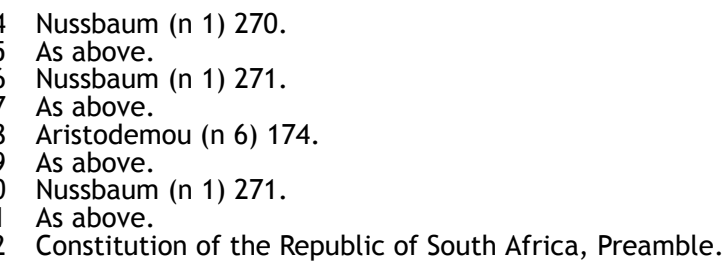


through the interplay between different forces of humanity such as psychology, politics, law and literature. ${ }^{33}$ This interplay also includes the engagement of and interaction with these forces by students on a tertiary level in order to drive socio-political change in legal education and legal culture. ${ }^{34}$

Central to healing and growth is a psychological transformation. Steve Biko explained the notion of a black inferiority complex as the persisting result of systemic and psychological oppression in the pre1994 era that demeans and belittles the experiences and voices of African people to an inferior status than those of European people. ${ }^{35}$ The Black Consciousness Movement (BCM) sought to re-instil pride and self-worth in African people as a means of correcting the psychological oppression of Africans in a pre-1994 era. ${ }^{36}$

The pre-democratic society did not only repress the experience and voices of African people but also those of women. Similar is the effect of cultural and social classifications that stem from the system of patriarchy that is dominant in society, by also denying the value of female perspectives and typically 'feminine' approaches to the law. ${ }^{37}$ Patriarchy structurally influences the upholding and enforcing of male power and domination, as well as male-centred and masculine structures in law. ${ }^{38}$ The so-called 'dichotomies' in legal thinking diminish feminine approaches to education such as, that the perception that the study of humanity and society that arises from the study of literature as part of legal education is inferior to formalistic legal education. ${ }^{39}$ The perception that African people and women and their Afrocentric and feminine ways of thinking and producing knowledge remain inferior or 'less-than' persists even in the modern experiences of these groups. ${ }^{40}$ This oppression and devaluation shape a psychology of dismissal or negation of the possible value and relevance of these approaches to the law and legal education.

When English literature is more diverse and inclusive in exposing students to alternative perspectives that are typically negated, it becomes crucial in transforming the view pertaining to African and female experiences as inferior in value. In exposing law students to these voices and experiences, the process of the BCM's aim of transforming the psychology of African people, and perhaps women too, is continued. This is achieved by offering representation of their

33 N Manganyi 'Public policy and the transformation of education in South Africa' in Sayed, Y \& Jansen, J (eds) Implementing education policies: The South African experience (2001) 28.

34 Manganyi (n 33) 28.

35 Biko (n 7) 22.

36 Biko (n 7) 53.

37 Van Marle \& Bonthuys (n 7) 29.

38 Van Marle \& Bonthuys (n 7) 21.

39 Van Marle \& Bonthuys (n 7) 30.

40 Lindfors (n 6) 6. 
unique lived experiences as portrayed through literature on an equal, non-hierarchical level in value and relevance to Eurocentric and male or 'masculine' voices that shape the perception of humanity for law students. 41

Little or limited transformation of the literature studied, as well as selective and limited inclusion of predominantly male African authors, can be utilised as a dangerous tool to reinforce only dominant voices as superior or relevant. ${ }^{42}$ Pre-1994, only European and predominantly male experiences were considered of any worth and African and female voices were either oppressed or dismissed as unimportant. ${ }^{43}$ In an era of democratic ideals and constitutionally promised equality, no one perspective is dominant if substantive equality is achieved. The substantive transformation of the literature syllabus is imperative to include diverse and previously undervalued voices in the experience of legal education as equal in value and relevance to Eurocentric and male perspectives. This also promotes the practice of equality on a more philosophical level in offering differing and even conflicting perspectives equal status in the study of literature and through this, the study of law as a social profession. ${ }^{44}$ The dangers of not ensuring substantive rather than superficial transformation include creating a disconnection between the Constitutional and transformative gains made in legal culture and the fairly limited and restricted male and European approaches to literature for law students. ${ }^{45}$

Legal education is increasingly transformative in applying feminist and queer theory, critical race theory, and critical legal studies. ${ }^{46} \mathrm{~A}$ formalistic and restricted jurisprudential approach that only values objective, formal rules of law as relevant to legal education can be utilised to enforce the historically oppressive and in-egalitarian relations between deemed 'alternative' knowledge, experiences and perspectives such as those presented to law students in literature. ${ }^{47}$

The onus then shifts to the trans-disciplinary nature of post-1994 legal education for further substantive and overarching transformation. ${ }^{48}$ This trans-disciplinary approach promotes a change in the acquisition of knowledge in legal education, which in turn promotes cooperation between people and ensures a joint responsibility for progress and transformative change as a result of the interconnected and interdependent nature of social fields of

41 Van Marle \& Bonthuys (n 7) 30.

42 Minda (n 3) 113.

43 Minda (n 3) 106.

44 Sec 9 of the Constitution of the Republic of South Africa. See also Aristodemou (n 6) 162.

45 Klare (n 12) 151.

46 Minda (n 3) 109.

47 Minda (n 3) 106.

48 Manganyi (n 33) 28. 
study such as law and literature. ${ }^{49}$ By prescribing both European and African, and male and female texts as equal in status in literature courses, law students are taught to afford equal consideration, value and attention to differing and even contrasting perspectives and to value the enriching dimension of diversity in understanding humanity and working in the legal profession. ${ }^{50}$

This contributes to what Yusef Waghid labels the on-going process of rethinking and redefining the prevalent culture in education. ${ }^{51}$ In response to a democratic era and in incorporating the approach of the Critical Legal Studies scholars in legal education, transformation needs to be an on-going, ever changing journey for the law student into social responsibility and integration of various conflicting or contrasting worldviews and perspectives, so as to better understand and value alternative perspectives to previously dominant ones. ${ }^{52}$ This promotes more direct societal involvement for legal professionals as members of a social profession, which in turn promotes further transformation by producing lawyers who engage in trans-disciplinary legal education to address political and social problems in South Africa, as interactive and engaging components of society. ${ }^{53}$ This also plays a role in promoting ethical legal practice by working with society as fellow humans rather than approaching society from a purely formalistic legal perspective.

Afrocentric transformation features the reframing of European and Western perspectives and experiences through an African lens that is sensitive and aware of African values and experiences. ${ }^{54}$ This is also evident in the call for 'Africanisation' of literary studies. ${ }^{55}$ By studying African and female texts that are authored by African and female authors, African people and women see their experiences reflected in the world around them and also see their experiences as valuable and worthy of acknowledgement. ${ }^{56}$ For law students this illustrates crucial legal and philosophical perspectives that directly impact every aspect of the legal profession and promotes transformation in contributing to the liberation and healing of black and female psychological inferiority complexes. ${ }^{57}$ The psychological liberation of Africans and women through the validation of being valued as crucial to the concept of humanity in legal education, directly promotes transformation in tertiary education. Furthermore,

49 Waghid (n 3) 459.

50 Nussbaum (n 1) 277.

51 Waghid (n 3) 458.

52 As above.

53 Waghid (n 3) 461.

54 P Hugo 'Transformation: The changing context of academia in post-apartheid South Africa' (1998) 97 African Affairs 24.

55 A Mazrui 'Shakespeare in Africa: Between English and Swahili literature' (1996) 27 Research in African Literatures 65.

56 Hugo (n 54) 27.

57 Biko (n 7) 53. 
transformation through valuing multiple and diverse perspectives promotes reconciliation and healing for South Africa and within legal education as a field dominated by Eurocentric and masculine ideals. 58 By acknowledging the value of African and female experiences, an Afrocentric approach may be adopted. This includes approaching literature from all backgrounds from the position of an African vision. ${ }^{59}$ This is crucial in correcting the inferiority present in African psychology by not alienating African perspectives as an 'appendage of the West'.60

\section{If the Western perspective is still relevant}

This prompts a discussion of the role of Western and European perspectives in African legal education. One may argue that an Afrocentric approach to literature studies would negate the need for European texts in the syllabus at all. ${ }^{61}$ However, replacing one dominant perspective with another does not promote transformation and social progression, but rather a continued cycle of one aspect of the human experience being deemed superior at the expense of another. Western English literature has a deep history and is relevant to many human experiences. ${ }^{62}$ Approaching European literature from an Afrocentric perspective may promote additional transformation of legal education in teaching law students to accommodate external or Western perspectives in the Constitutional era's specific focus on equality, diversity and transformative progress. ${ }^{63}$ This also teaches law students to incorporate various worldviews and experiences in a manner that ensures that no one perspective is valued as dominant and that multiple human experiences can be valued without encroaching on or being thwarted by another. ${ }^{64}$ Such a co-operation of perspectives fosters an approach to law and society that features joint and mutual responsibility for transformative change between law students and lawyers, and the society they interact with. ${ }^{65}$

58 Klare (n 12) 68.

59 Hugo (n 54) 26.

60 Hugo (n 54) 26 and Biko (n 7) 22.

61 Mazrui (n 55) 64.

62 Mazrui (n 55) 76.

63 Mazrui (n 55) 65.

64 Biko (n 7) 22.

65 Waghid (n 2) 471. 


\section{How the current English syllabus has become more inclusive but fails to meet expectations of transformation}

After 1994, an effort was made to reform and reorganise the texts being studied in South African universities to be more inclusive and representative of South Africa. ${ }^{66}$ This included both introducing texts about African and female experiences and texts written by African and female authors. ${ }^{67}$

Both LLB and BA Law students typically complete the modules ENG 110 and 120 and BA Law students go further to also complete ENG 210 and 220. ENG 110 covers 'pre-twentieth century era' texts, ENG 120 covers ' post-nineteenth century' literature, ENG 210 covers 'Modern English literature and English language studies' and ENG 220 'Twentieth-century and postcolonial' literature. ${ }^{68}$

The introduction of more African and female texts is evident in the prescribed texts for 2018 English literature courses for law students at the University of Pretoria. ${ }^{69}$ However, the unequal divide between texts authored by white males and black males, as well as males overall and females overall is strikingly apparent. Excluding selected poets in a South African poetry section of the 120 module, ENG 110 and 120 collectively feature seven white male writers of novels and plays (of which two are South African namely Medalie as contributor and Fugard) and one black male writer, Achebe. ${ }^{70}$ Only one female author of novels and plays is studied in ENG 110 and 120 and that is Dangarembga with her award-winning novel 'Nervous Conditions'. ${ }^{71}$ The value awarded to European knowledge as superior is still evident in the ratio of white South African authors being included as African voices, as compared to the one black and Nigerian novelist voicing black African experiences. Other literature in the course classified as 'African literature' is Conrad's 'Heart of Darkness'. While being set in Africa and regarding African history, the text is arguably not transformative in nature in being included on the syllabus as it reinforces the Eurocentric evaluation of relevance in valuing Conrad's Western portrayal of an African experience as an African perspective. ${ }^{72}$

Lindfors (n 6) 6.

As above.

University of Pretoria, Department of English ENG 110, 120, 210 and 220 study guides (2018).

As above.

As above.

As above.

Lindfors (n 6) 13. 
Little difference is seen in ENG 210 and 220 which collectively feature eight novels and plays by white males (of which one author is South African, JM Coetzee) and two by black males (of which neither are South Africa but one author is African, Ngũgĩ wa Thiong'o). ${ }^{73}$ There is also a prominent racial divide between female authors of prose and drama, where in ENG 210, 'Modernism and Language Studies', there are two female European writers and in ENG 220's 'Twentieth-century and postcolonial literature', there are two female African writers. ${ }^{74}$ The ENG 220 module does, however, also include additional nonEuropean texts such as Caribbean and South African poetry and Asiancentric texts by authors such as Hamid and Kureishi, as well as female author Julie Otsuka. ${ }^{75}$ However, the prominent bias that still exists in the syllabus towards European male authors such as Yeats, Joyce and Miller highlights the unequal weighing of value awarded to these authors in favour of female and African authors such as Omotoso and Adichie. ${ }^{76}$ Despite this, the diverse perspectives included in the ENG 220 module arguably make it the most transformative of the English literature modules in presenting non-European views and both male and female voices as valuable and representative of society. This is problematic when considering that the LLB program typically does not include ENG 220. LLB students are then only presented with two black writers, four African writers in total and only one female writer. ${ }^{77}$ For the BA Law student, the inclusion of ENG 220 in the program promotes consideration of diverse perspectives as well as a truly general jurisprudential approach in comparatively and substantively pursuing legal education from a truly trans-disciplinary approach. ${ }^{78}$

While the English syllabus has changed a great deal from pre-1994 trends, the transformation achieved through studying African and female texts in the syllabus lacks the substantive change needed to be truly transformative for law students, more so in a post-1994 era. ${ }^{79}$ The efforts of South African universities and specifically the University of Pretoria to reform the literature syllabus are limited and slow, but nonetheless, progressing. ${ }^{80}$ The inclusion - albeit limited inclusion - of African classics such as Achebe's 'Things fall apart' and Ngũgĩ's 'A grain of wheat' gives recognition to African voices, but are often included in only one literature course for law students (such as only ENG 120 for LLB students) and, while voicing African experiences, these African classics still expose law students to a male

73 University of Pretoria, Department of English ENG 110, 120, 210 and 220 study guides (2018).

74 As above.

75 As above.

76 Lindfors (n 6) 7.

77 University of Pretoria, Department of English ENG 110, 120, 210 and 220 study guides (2018).

78 Nussbaum (n 1) 272.

79 Klare (n 12) 151.

80 Lindfors (n 6) 6. 
dominated experience that reinforces the dominance of 'masculine' approaches to society being the preferred approach to law. ${ }^{81}$

The position of female African writers in English literature courses throughout South African universities is exceptionally limited to Dangarembga's 'Nervous conditions' and various novels by Gordimer, with few variations in texts between universities being studied. ${ }^{82}$ The divide between value and prominence awarded to male and specifically white male texts and African female and female texts is evident in the persisting preference for masculine approaches to legal education. ${ }^{83}$ The value placed on objectivity, rationality, analytical skills and impartiality illustrate the value of masculine traits over more subjective, contextual and emotive feminine approaches to law and legal studies. 84

\section{Conclusion}

In promoting transformation of legal education in post-1994 South Africa, law students are increasingly being trained from a transdisciplinary approach in that the study of literature forms part of the syllabus, albeit with slow transformative progress. This is in an effort to employ a general approach to jurisprudence and a Critical Legal studies perspective by including studies of the humanities in the study of law and acknowledging the role of disciplines such as literature in creating citizens of lawyers. ${ }^{85}$ The exposure of LLB students to literature in the law syllabus should aim to expose law students to varying and diverse experiences of different groups of society as portrayed in African and female literature. ${ }^{86}$

By presenting law students with predominantly Eurocentric and male texts in literature courses, transformative efforts of tertiary institutions lack significant or meaningful change. ${ }^{87}$ Mere inclusion of literature in legal education is limited in transformative potential as studying only one experience can be used to enforce dominant perspectives as superior and solely worthy of recognition. ${ }^{88}$ By including more diverse and even Afrocentric voices such as African and female writers in the English syllabus, law students are presented with more varied and more relatable texts in an African context that promotes understanding and sensitive consideration of previously

Lindfors (n 6) 8.

Lindfors (n 6) 7

Van Marle \& Bonthuys (n 7) 29.

As above.

Nussbaum (n 1) 271.

Nussbaum (n 1) 270.

Manganyi (n 34) 28.

88 Aristodemou (n 6) 177. 
marginalised voices and undervalued perspectives portrayed in literature. 89

The inclusion and appreciation of such perspectives is instrumental in correcting and addressing the psychological oppression of women and Africans following years of - and sometimes still persisting - systematic oppression in structures such as the patriarchy and the black inferiority complex. ${ }^{90}$

Furthermore, the role of English literature in legal education is also in declassifying the strict and formal categories of knowledge considered appropriate and relevant to legal studies, and incorporating and integrating typically liberal and subjective disciplines, such as literature and the arts, in a general jurisprudential approach to legal education in post-1994 South Africa. ${ }^{91}$ Such approaches are typically deemed 'feminine' and thus contribute to a Critical Legal studies approach to legal education in incorporating the value of feminine and other undervalued theoretical approaches to legal education. ${ }^{92}$

In creating ethical law students and later, ethical lawyers, English literature that is transformative in itself by incorporating diverse experiences in an equal, non-hierarchical manner, can promote an understanding and consideration for 'other' perspectives. ${ }^{93}$ This promotes an ethical consciousness in lawyers and is highlighted by the social nature of the legal discipline. ${ }^{94}$ Law is an integral part of humanity, and humanity an integral part of law. ${ }^{95}$

While literature courses feature some progression and development, there has been fairly limited transformation in ENG modules to include diverse and perceived 'alternate' perspectives such as female and African voices in studied texts. ${ }^{96}$ White male authors make up a large majority of the texts being studied by law students in literature courses which exhibits limited and superficial transformative measures. ${ }^{97}$ In striving for substantive transformation, including trans-disciplinary and diverse experiences and perspectives creates a legal consciousness that further plays a role in training ethical lawyers that will promote further transformation of society and legal education in their careers. ${ }^{98}$ 
Incorporating diverse and representative texts in literature courses for law students promotes a general jurisprudential approach to legal education in including the humanities in an inherently social field of study. ${ }^{99}$ This ensures substantive justice and an approach to law that values previously dismissed or devalued perspectives such as those of females, Africans and subjective, feminine and transdisciplinary approaches to legal education in post-1994 South Africa.

99 Nussbaum (n 1) 271. 


\section{A DISCUSSION OF INTELLECTUAL HISTORY, JURISPRUDENTIAL THEORIES AND FEMINISM IN THE ERADICATION OF EPISTEMIC VIOLENCE IN SOUTH AFRICA}

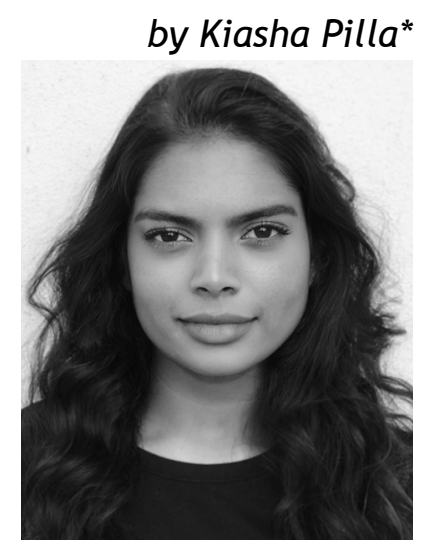

\section{Introduction}

This analysis and discussion of intellectual history, along with analysing theories concerned with legal pluralism, provides insight into the ideas and ideologies currently influencing jurisprudence that aims to eradicate epistemic violence. This paper will illustrate how the aforementioned analysis, along with the concept of transformative constitutionalism, actively contributes towards the development of jurisprudence that aims to diminish epistemic violence and the inequality that emanates from it. The paper will illustrate how theories concerned with legal pluralism, traditions and ideologies, such as Marxism, Black Consciousness, feminism and religion, all play a role in contributing towards the development of a critical jurisprudence that will aim to eradicate epistemic violence in several sectors of the South African society. This paper will further illustrate how feminism as an ideology, and in the field of sociological law, can uncover and subsequently empower hidden and marginalised narratives, thereby promote the eradication of epistemic violence. In addition, the paper will include an analysis of a feminist poem by a South African feminist scholar to highlight the relevance of the ideology of feminism in combatting epistemic violence.

* Third year LLB student, University of Pretoria. 


\section{How does intellectual history uncover and identify the roots of epistemic violence?}

Peter Vale discusses how South African intellectual history influences the change in ideas, and subsequently South African jurisprudence. ${ }^{1}$ Vale describes intellectual history as a change in ideas and ideologies, and uses this description to illustrate the 'migration of ideas to South Africa' and how this led to the development of South African intellectual history. ${ }^{2}$ Vale describes how the 'manifestation of ideas leads to the ideas influencing the ambitions of individuals and institutions', and how this pertains to South African society. ${ }^{3}$ The manner in which the 'intellectual traditions interacted with the South African struggles' is also used to highlight the importance and relevance of intellectual history in the development of South African jurisprudence. ${ }^{4}$ Vale then shows how the development of ideas and the migration of ideas to South Africa led to the 'rejection of indigenous knowledge and the embracing of English and Dutch traditions', and it must be acknowledged that this is essentially a form of epistemic violence. ${ }^{5}$ The concept of 'Little England on the Veld' and the exclusive embracing of Dutch and English knowledge marginalised indigenous peoples and their knowledge. ${ }^{6}$ This is perhaps one of the earliest forms of epistemic violence in South African jurisprudence. The development of ideologies and ideas through the study of intellectual history, according to Vale, is illustrative of the development of epistemic violence accordingly. ${ }^{7}$ The inception of epistemic violence in South Africa, according to Vale's findings, seems to be attributed to the influence of colonialism and, subsequently, the system of apartheid. ${ }^{8}$

Savo Heleta concurs with Vale's conclusion on this matter, as she acknowledges that "the persistence of epistemic violence in postapartheid South Africa is rooted in colonial and apartheid exploitation and racism". 9 Heleta argues that "colonial and apartheid marginalisation, racism and exploitation live on in many spheres of life and work'. ${ }^{10}$ This statement is accurate when considering the current prevalence of epistemic violence in South Africa, and in

$1 \quad \mathrm{P}$ Vale Of ships, bedraggled crews and the miscegenation of ideas. Interpreting intellectual traditions in South Africa (2014) 3.

2 Vale (n 1) 3.

3 As above.

As above.

Vale (n 1) 8.

Vale (n 1) 9.

Vale (n 1) 8.

As above.

S Heleta, 'Decolonisation of higher education: Dismantling epistemic violence and Eurocentrism in South Africa' Transformation in Higher Education Journal 1(1) 20163.

10 Heleta (n 9) 9. 
several aspects of South African society, such as race, gender and religion. Heleta further analyses epistemic violence and its roots by acknowledging that the emancipation of black South Africans cannot be fully achieved unless the 'many structural imbalances, remaining inequalities and stumbling blocks' that exist in the sphere of epistemic violence, are removed. ${ }^{11}$

Through these studies of intellectual history and the development of ideologies surrounding the acceptance of colonial knowledge and the roots of epistemic violence, it becomes evident that epistemic violence is indeed entrenched in South African society, and is apparent in many facets of society, including the legal sphere. Judge Weinkove's statement is one of the many examples of this entrenchment of epistemic violence, pertaining to class in particular. ${ }^{12}$ Epistemic violence has undoubtedly affected particular classes and groups of people within South Africa, some more than others, with the reality of historically marginalised classes and groups being directly affected by the phenomenon. Epistemic violence is responded to by intellectual history, through the identification of the roots of epistemic violence and its effects on society. Intellectual history, as illustrated by Vale and Heleta, is capable of exposing the nature of epistemic violence and providing us with the necessary background on the matter. This aids in identifying the specific sectors of society that epistemic violence most impacts. Once this is achieved, a more critical jurisprudence, which encompasses solutions for the problem of epistemic violence, can be developed through the law, using traditional and modern theories such as feminism, Black Consciousness and legal pluralism.

\section{How does a restricted jurisprudence contribute towards the prevalence of epistemic violence?}

Douzinas and Gearey explore the exposition of the shift from a general to a restricted jurisprudence. ${ }^{13}$ This is illustrative of a 'story of decline' seen in both South African jurisprudence and in the reemergence of epistemic violence in a democratic society where marginalisation is still very prominent. ${ }^{14}$ The shift from a general to a restricted jurisprudence encompasses the 'gradual diminution of the scope of the law' and the prominence of epistemic violence can

11 Heleta (n 9) 1.

12 SF De Beer Urban social movements in South Africa today: Its meaning for theological education and the church (2014) 2.

13 C Douzinas and A Gearey From restricted to general jurisprudence (2005) 3.

14 Douzinas and Gearey (n 13) 4. 
be partly attributed to this. ${ }^{15}$ Epistemic diversity and epistemic justice can be achieved if we are able to include previously marginalised narratives and voices that are excluded by our current jurisprudence. One of the most crucial steps in ensuring the aforementioned can occur, is the development of a more general jurisprudence. This would entail a culmination of the various legal traditions and ideologies that exist within the scope of law, and ideologies developed in different disciplines such as psychology, philosophy, etc. A more general jurisprudence also allows for the inclusion of narratives that were previously excluded: narratives stemming from these disciplines. Douzinas and Gearey state that 'a general jurisprudence examines ways in which subjectivity is created as a site of freedom and of subjection', and this illustrates how a general jurisprudence encourages emancipatory methods for the marginalised narratives in society. ${ }^{16}$

\section{Analysing epistemic violence through the lenses of various intellectual traditions}

The theories concerning legal pluralism, like intellectual history and a general jurisprudence, contribute towards the development of a critical jurisprudence that will alleviate forms of epistemic violence. Veitch's analysis of legal pluralism is centred around the concept of 'presenting an alternative paradigm to the law'. ${ }^{17}$ When compared to legal modernity, this explains how the scope of law is problematic in South African jurisprudence. The law is perceived as 'lawyer's law', and this highlights how 'state-law is hindered by non-state law'.18 Veitch describes how it is necessary to focus on the development of contemporary legal pluralism, as it encourages the growth of empirical socio-legal studies, inclusive of ideologies such as feminism, Black Consciousness and religious traditions. ${ }^{19}$ Contemporary legal pluralism assists in the development of these ideologies. It also encourages greater focus on how law operates with these ideologies in practice, instead of encouraging a focus on the doctrinal analysis of law, which pertains to only focusing on 'law in the books'. ${ }^{20}$ This focus on contemporary legal pluralism encourages the development of a critical jurisprudence that considers the effects of law and how law is practiced in society. This further encourages a jurisprudence that is more general and inclusive on contemporary ideologies.

15 As above.

16 Douzinas and Gearey (n 13) 10.

17 S Veitch Legal pluralism (2014) 207.

18 As above.

19 Veitch (n 17) 208.

20 As above. 
Veitch discusses how law is at the centre of Marxist theory and how the Marxist concept of economy shapes society in contemporaneity. ${ }^{21}$ This illustrates how certain Marxist economic theories and theories on capitalism can be used to make a distinction between a more inclusive jurisprudence and a restrictive jurisprudence that is influenced by these theories. The Marxist concept of economy is perceived as the determinant of 'the shape and function of all institutions in society'. ${ }^{22}$ This concept can be used to interpret the way in which a state's economy functions in relation to its societal facets however, it is not inclusive of many other ideologies and theories that influence our current jurisprudence. Another Marxist theory can be used to make a distinction between theories hindering the development of an inclusive jurisprudence and those developing it: Identity in law as legal subjects. ${ }^{23}$ Marx stated that one's sense of identity is dependent on one's interaction with others and that 'as legal subjects we are tied together by money and our ability to buy and sell'. 24 This view on the concept would encourage a more restrictive jurisprudence however, the law 'abstracts from social identity', which encourages a more inclusive jurisprudence. ${ }^{25}$ Veitch further analyses Foucault's concept of juridical regression in his findings on power and discipline and how this hinders the development of an inclusive jurisprudence. ${ }^{26}$ This concept pertains to the regression of traditional law and ideologies, perhaps due to lack of modern relevance, and the emergence of theories relating to modernity. When taking cognisance of this, it is important to consider traditional ideologies and theories of law and in other disciplines, especially for the development of a more inclusive jurisprudence.

Mabogo P More discusses the philosophical roots of one of these traditions namely, Black Consciousness, in 'The Intellectual foundations of the Black Consciousness Movement'. 27 He discusses how the political and intellectual ideas surrounding Black Consciousness must be understood by looking at the 'philosophical, political, social and religious milieu from which they emanated'.28 This is a prime example of an ideology that is extremely inclusive and would contribute towards developing a more general critical jurisprudence. The crux of More's discussion is the definition of Black Consciousness as 'both a movement and a philosophy, and how 'Black Consciousness has always been the only liberation movement whose

21 S Veitch Law, ideology and legitimation: The Marxist critique (2018) 227.

22 As above.

23 Veitch (n 21) 228.

24 Veitch (n 21) 227.

25 As above.

26 M Foucault Displacing the juridical: Foucault on power and discipline (1984) 236.

27 PM More The intellectual foundations of the Black Consciousness Movement (2014) 173.

28 As above. 
ideas were generally referred to as a philosophy'. ${ }^{29}$ The inclusion of a philosophical approach to an ideology that emancipates and demarginalises black South Africans signifies an important method in developing a more inclusive and general jurisprudence. Black Consciousness is essential for the de-marginalisation of previously oppressed black South Africans. This is essential for the development of a jurisprudence that is capable of the eradication of epistemic violence. More states the Black Consciousness is importantly inclusive and states that 'Black Consciousness is a form of consciousness, a mode of being-in-the-world'.30 More further discusses how Black Consciousness 'led to the emergence of black theology within the Black Consciousness Movement', and how this led to both concepts being advocated for by the likes of Desmond Tutu and Allan Boesak. ${ }^{31}$ This is indicative of the fact that the ideology of Black Consciousness was inclusive of religion too, and capable of contributing towards a jurisprudence that can eradicate epistemic violence pertaining to both race and religion.

The same inclusivity can be attributed to Islamic intellectual traditions in South Africa as explored by Muhammed Haron in 'Islam, Intellectuals and the South African question'. ${ }^{32}$ Harom explores the contributions of Muslim activists and thinkers towards securing an 'intellectual tradition' in the country, and thereby contributing towards a developing, more general jurisprudence, capable of eradicating religious epistemic violence. Haron highlights the emergence of the 'humanist approach' to Islamic intellectual traditions, which entails a more contemporary interpretation of Islam. ${ }^{33}$ This contemporary interpretation is inclusive of the relation of Islamic traditions and culture, and the ability to adapt to 'the demands of modernity and political change'. ${ }^{34}$ According to this approach, the vibrancy and critical nature of Muslims must be highlighted in order to give a sense of human agency to this group of people, which is illustrative of the ability of Islamic intellectual traditions to contribute towards eradicating epistemic violence. ${ }^{35}$ Islamic religious organisations and the leaders of these organisations, are typically intellectuals that had entered the struggle against apartheid and joined political organisations such as the Natal Indian Congress and the SACP in the 1950's and 1960's. These intellectuals also contributed towards 'international Muslim resurgence' which illustrates the contributions of Islamic intellectual traditions towards

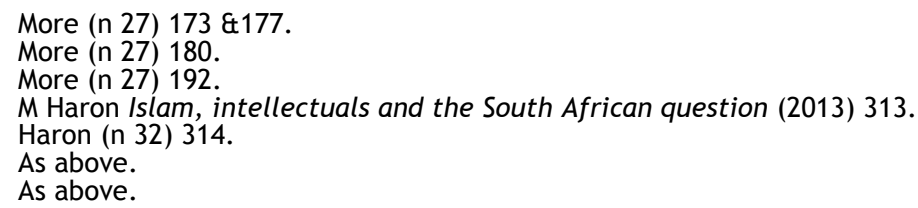


eradicating racial inequalities, and thereby, eradicating epistemic violence to an extent. ${ }^{36}$

\section{Understanding the prominence of gender- based epistemic violence through feminism}

An increasingly prominent form of epistemic violence is genderrelated epistemic violence, which is addressed by the ideology of feminism. Van Marle in 'We exist, but who are we? Feminism and the Power of sociological law', questions whether law has been decentred by feminism or not, with reference to Carol Smart's claim that feminism can indeed decentre law. ${ }^{37}$ Van Marle addresses Smart's argument against the development of a feminist jurisprudence by stating that it allows females to work at a conceptual level, enabling society to engage with both the power of the law and feminism. ${ }^{38}$ Van Marle also addresses Smart's claim that law has been decentred by feminism by arguing that the law is growing increasingly relevant in women's lives. ${ }^{39}$ I believe this to be a good argument against Smart's claims, as Van Marle's arguments encourage a strain of feminism that can combat the marginalisation of women through the application and practice of the law.

Helen Moffett specifies how feminism contributed towards both South African traditional and political traditions, and echoes Van Marle's arguments for the same contributions of feminism. ${ }^{40}$ Moffett also addresses the current marginalisation of women and feminism as an ideology, by examining how 'the actual political paradigms of feminism remain largely misunderstood or ignored'. ${ }^{41}$ Moffett makes two observations regarding the inclusion of women in society through the law and that contributes towards the ability of feminism to eradicate epistemic violence pertaining to gender. These observations are namely, that 'historically, women were active in the anti-apartheid struggle' and that 'women are numerically wellrepresented in government'. 42 She also highlights that this renders visible what had been erased and marginalised for centuries: 'women's history, work and cultural contributions'. 43 This is indicative of how feminism in law has the ability to give agency to the previously marginalised and contribute towards eradicating epistemic violence. Moffett analyses the feminist mechanisms used against

36 As above.

37 K Van Marle We exist, but who are we? Feminism and the power of sociological law (2012) 149.

38 As above.

39 As above.

40 H Moffett, Feminism and the South African polity: A failed marriage (2014) 219.

41 Moffett (n 40) 220.

42 As above.

43 Moffett (n 40) 221. 
apartheid, and how organisations such as the ANC Women's League and Black Sash were a product of different feminist groupings, according to race and class, becoming allies in the search for social change for women. ${ }^{44}$ This analysis is indicative of how feminism as an ideology was capable of grouping together women that were previously separated from one another in a social context. This was achieved by allowing them to find a common goal: that of being equal. This illustrates how feminism is able to eradicate this particular form of epistemic violence.

Jennifer Thorpe's poem, 'Order in the mother city', in Appendix A, illustrates how women of different backgrounds and of different social circumstances, living in the apartheid era, were divided by circumstance, but could relate on the basis of wanting to be emancipated from the shackles of patriarchy and domestic abuse. ${ }^{45}$ This particular example of feminist poetry gives us insight into how women that are domestically abused, irrespective of race or class, are marginalised in society, and how feminism can be used an emancipatory tool for women with very different narratives. If used in this way, feminism has perhaps the greatest potential for contributing towards the development of a jurisprudence that is more inclusive of upholding women's rights and protecting women, thereby assisting in the eradication of epistemic violence.

\section{Conclusion}

There are several theories and ideologies that can contribute towards the development of South African jurisprudence so that it encompasses the inclusion of more groups, races and types of people in society. Intellectual history is essential in analysing the root-causes of epistemic violence and in understanding the socio-economic and gender-based developments that resulted in marginalisation to this extent. The understanding of the narrowing of the scope of jurisprudential theory and the subsequent shift from a general to a restricted jurisprudence can greatly benefit South Africans in the legal field in cultivating possible solutions to epistemic violence. Analysing the effect of how law is practiced in society through the lens of legal pluralism can encourage the development of a jurisprudence that is more inclusive of contemporary ideologies such as feminism, Black Consciousness and religious traditions. The law has the ability to develop a jurisprudence like this through the influence of both traditional and modern legal philosophies, traditions and theories. In order for epistemic justice to be achieved, the law must envelop these philosophies, traditions and theories, especially those 
of feminism and Black Consciousness, which relate to perhaps the two most prominent forms of epistemic violence: gender and race.

\section{ANNEXURE A}

\section{Order in the Mother City - Jennifer Thorpe}

1 It was

2 The force of the wall

3 That propelled her face forward

$4 \quad$ And back into the foot

5 That kicked it.

6 The kicker danced

7 The dance of a victorious soldier.

8 For he was a warrior in a long standing campaign

9 Of dominance

10 And hate.

11 Behind the wall,

12 And hidden from view,

13 A young girl played on her swing set

14 Took selfies with her Ipad

15 Unaware of the violence beyond.

16 Her mother

17 Was not abused

18 Just disabused of the notion

19 That one day she would come home

20 To find dinner on the table.

21 Along the street

22 A more hopeful woman walked

23 Witnessed the scene

24 And called the police

25 To restore order.

26 The police arrived 


\section{ABSTRACT SUBSTANTIVE-EQUALITY - A CRITICAL RACE THEORY ANALYSIS OF 'HATE SPEECH' AS CONSIDERED IN THE SAHRC-REPORT ON UTTERANCES MADE BY JULIUS MALEMA}

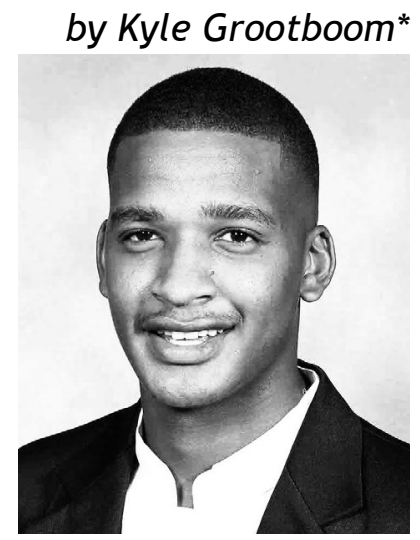

'Thus, with regard to the application of justice it accords primacy to the concrete, the world of the living. In this sense it is different from Western legal thought which apparently stresses the abstract."1

\section{Introduction}

In the following article I will critically analyse the concept of hate speech as it was considered in the South African Human Rights

* Third year LLB Law student at the University of Pretoria. This article is an adapted version of an essay submitted by me in completion of the module JUR 310 under Dr Joel Modiri. In this article I critique hate speech laws, a narrow view of racism and the fallibility of these concepts in contributing to a more substantially equal society. I would like to thank Primrose ER Kurasha, Frieda Shifotoka and Thato P Maruapula for helping me in making my article more presentable through their feedback and engagement. All errors and shortcomings are undeniably my own. To my mother Daleen Grootboom and brother Cohen Grootboom, I send a thousand kisses. And lastly, in the words of Earl Sweatshirt: 'There's not a black woman i can't thank!'.

1 M Ramose 'an African Perspective on Justice and Race' (2001) polylog: Forum for Intellectual Philosophy http://them.polylog.org/3/frm-en.htm (accessed 30 August 2019). 
Commission's (the 'Commission') report on utterances made by Julius Malema (the 'report'). ${ }^{2}$ The critique will be delivered by way of Critical Race Theory (CRT) as I aim to illustrate the Commission's narrow interpretation of racism in light of hate speech. Because the Commission relies on an array of court judgments and equality legislation to form its equality jurisprudence on hate speech, my critique will also set out to show that the Commission's equality jurisprudence is reflective of the Constitution and the courts' narrow understanding of racism. I aim to argue that a narrow understanding of racism leads to a very abstract equality jurisprudence.

I will illustrate that an equal emphasis on substantive equality, if not more, is necessary to fully address socio-economic inequality. This is so because I argue that hate speech manifests as a result of the substantive inequality amongst people. A more adequate solution would therefore be to address substantive inequality, instead of remedying hate speech, which is merely a consequence. ${ }^{3}$

I will use CRT to analyse hate speech as it was considered in the report, because as postulated above, inequality in South Africa is for the most part racialised because of the country's colonial apartheid past. ${ }^{4}$ I will rely on Derrick Bell's article entitled 'Who's afraid of Critical Race Theory?' in my understanding and application of critical race theory throughout my analysis. ${ }^{5}$ The aforementioned article offers an approach to critique the law from the perspective of the black oppressed. It primarily sets out how the law enables and entrenches racial oppression. It also offers techniques for a critical race critique of the law. ${ }^{6}$

I will make use of Transformative Constitutionalism and Decolonisation as theories that aim to address and redress the injustices of the past. Transformative constitutionalism, according to Karl Klare in the article 'Legal Culture and Transformative Constitutionalism', recognises the injustices of the past and believes that the Constitution can be used as a tool to address and redress those injustices if interpreted in a transformative way. ${ }^{7}$ I aim to illustrate how Transformative Constitutionalism aligns itself with a narrow understanding of racism and thus abstract equality. Decolonisation takes the legal reform debate much further in

2 The South African Human Rights Commission ('Commission') 'Report on utterances made by Julius Malema and Another' (March 2019).

3 J Modiri 'The “event” of racism' Daily Maverick 17 November 2016 https://www. dailymaverick.co.za/opinionista/2016-11-17-the-event-of-racism/ (accessed on 16 September 2019).

4 D Bell 'Who's afraid of critical race theory' (1995) University of Illinois Law Review 893 - 910.

5 Bell (n 4) $893-895$.

6 Bell (n 4) 899. Also note 'Black people' in this essay alludes to African, Coloured and Indian people in South Africa.

7 K Klare 'Legal Culture and Transformative Constitutionalism' (1998) 14 South African Journal on Human Rights at $146-188$. 
asserting and interrogating the law, equality and notions of what it means to be a human being from deeply African perspectives. ${ }^{8}$ I will discuss decolonisation from the perspectives of Kwasi Wiredu's 'Conceptual Decolonization as an Imperative in Contemporary African Philosophy: Some Personal Reflections' and T Serequeberhan's 'African Philosophy as the Practice of Resistance'. ${ }^{9}$ It is my aim to show that decolonisation much like CRT aligns itself with a broader understanding of racism and thus a substantive notion of equality.

\section{A brief differentiation between abstract and substantive - equality}

The concepts of 'substantive rights and equality' are established legal terms especially in constitutional jurisprudence and it alludes to rights such as that in the Bill of Rights as opposed to procedural rights. ${ }^{10}$ For the purposes of this essay however, a differentiation is drawn between abstract and substantive rights and equality. The two concepts are also more philosophically defined, instead of legally defined. Where abstract rights and equality relates to a detachment from the lived, substantive and socio-economic conditions of people. ${ }^{11}$ Abstract rights can thus be describe as political rights or the protection of rights of which the objects are not possessed and accessible by people. ${ }^{12}$ Furthermore, substantive equality, in this essay relates to economic rights which have concrete and material manifestations, like property rights, food and healthcare. Substantive rights and equality as understood in this essay necessarily place a positive obligation on the state.

The following serves as an example to illustrate how substantive and abstract rights and equality are understood in this essay; the right to access to the courts, is entrenched in the Bill of Rights of the South African Constitution and is traditionally seen as a substantive right. In this article however, it would be seen as an abstract right since a lot of people to do not have access to the courts for a variety of reasons such as, location and affordability as will be discussed below. Thus, although various rights are substantive on paper, for the purposes of this essay, they will only become substantive once they manifest and

8 Ramose (n 1) 1.

9 K Wiredu 'Conceptual Decolonization as an Imperative in Contemporary African Philosophy: Some Personal Reflections' (2002) 36 Rue Descartes 53 - 64. See also T Serequeberhan 'African Philosophy as the Practice of Resistance' (2009) 4 Journal of Philosophy: A Cross-disciplinary Inquiry 44-5.

10 Klare (n 7) 54.

11 A Kok 'The Promotion of Equality and Prevention of Unfair Discrimination Act 4 of 2000: Court-driven or legislature-driven societal transformation?' (2008) 1 Stellenbosch Law Review at 133.

12 CRM Dlamini 'Equality or justice? Section 2 of the Constitution revisited - Part I' 27(2) Journal for Juridical Science 2002 at $15-32$. 
become a concrete reality for people, however, until then they will be deemed abstract, for the purposes of this essay. It is also fitting to state at this stage of the introduction that 'post'-apartheid South Africa is often cited by scholars as the political emancipation of black people but not the substantive, economic emancipation. ${ }^{13}$

In this essay, abstract rights mean rights and in turn a notion of equality that is detached from the reality of racialised inequality, rights which are unattainable by the majority of oppressed black people and rights which merely exist as ideals, as will be illustrated below. ${ }^{14}$ This would be rights such as freedom of expression and dignity. It is posited that abstract rights and equality is reflective of a narrow view of race and racism. A narrow view of racism, as critiqued by the concept of CRT, is a view that sees racism as determinable individual acts of racial bigotry towards people of a specific racial group. CRT, however, defines racism as the systemic oppression of black people for the benefit of white privilege. The concept of hate speech (insofar as it is racialised, as will be critiqued) is thus one of the repercussions of the aforementioned narrow view of racism and abstract equality.

\section{Summary of the SAHRC-Report on hate speech}

The Commission was tasked with investing four instances of alleged hate speech made by Julius Malema and one instance of hate speech made by Godrich Gardee during electioneering campaigns and political rallies dating from 2016 TO 2018. ${ }^{15}$

The Commission first delved into the constitutional provisions relating to hate speech. ${ }^{16}$ The Commission stated that the right to human dignity informs both the right to equality as guaranteed in section 2 of the Constitution, and the right to freedom of expression as guaranteed in section 16(1) of the Constitution. ${ }^{17}$ It was held that the freedom of expression is not absolute but a balance needs to be found between freedom of expression and the right to equality. ${ }^{18}$ It flows that this balance is found in section 16(2) of the Constitution, which holds that harmful expression does not enjoy constitutional https://www.academia.edu/27141915/THE_NGUNI_PERSPECTIVE_OF_UBUNTU (accessed 5 September 2019).

15 The SAHRC Report (n 2) 1 - 3.

16 The SAHRC Report (n 2) 5.

17 The SAHRC Report (n 2 ) 2.

18 As above. 
protection, and furthermore in the section, the 'advocacy of hatred' is expressly excluded in section $16(2)(c) .{ }^{19}$

The 'advocacy of hatred' i.e. hate speech is not constitutionally protected and is further statutorily prohibited by section 10 of Promotion of Equality and Prevention of Discrimination Act (PEPUDA). ${ }^{20}$ The Commission's report states that section 10 of PEPUDA is a limitation in terms of section 36 of the Constitution. ${ }^{21} \mathrm{~A}$ conjunctive interpretation of section 10 of PEPUDA or a combination between a conjunctive and disjunctive approach saves it from being an unlawful limitation in terms of section 36 of the Constitution. A conjunctive reading would require that all of the elements of hate speech be present for it to constitute such. This means that expression must be 'hurtful and harmful and promote hatred' for it to be a hate speech. A disjunctive reading requires that hurts may be 'hurtful or harmful or promote hatred' for the utterance in question to constitute hate speech. It is stated in the report that there is currently no precedent for which reading would be more appropriate. The Commission thus proceeded to use both readings; this means that the Commission used either a disjunctive reading or a conjunctive reading depending on each one's relevance. The commission also stated that an objective test is required for hate speech and this entails that hate speech would be determined without taking into consideration the subjective intentions of the person who utters the words. ${ }^{22}$

The Commission then pointed out that establishing context when it comes to hate speech is pertinent and very much a requirement in terms of section 3(3) of PEPUDA. ${ }^{23}$ It was stated that the factual, social and historical context of a statement needs to be considered and the fact that an alleged expression of hate speech is directed at vulnerable groups or individuals would make a finding to that Effect more likely. ${ }^{24}$

Afterwards the Commission applied its jurisprudence of hate speech to the five statements.

The first statement was made by Julius Malema in 2016 with regard to land dispossession and white people which reads:

They found peaceful Africans here. They killed them. They slaughtered them like animals. We are not calling for the slaughtering of white people, at least for now. What we are calling for is the peaceful occupation of the land and we don't owe anyone an apology for that... 25

19 The SAHRC Report (n 2) 5 - 7.

20 As above.

21 As above.

22 The SAHRC Report (n 2) 7 - 15.

23 The SAHRC Report (n 2) 5.

24 The SAHRC Report (n 2) 15.

25 The SAHRC Report (n 2) $17-20$. 
The Commission held that, viewed in a historical, social and factual context, the statement does not amount to hate speech, as the statement was made with regard to land dispossession and not intended to incite any harm towards white people. ${ }^{26}$

The second statement was made by Julius Malema in August 2017 and reads:

Here in Durban, here in $\mathrm{KZN}$, everything strategic is given to Indian families ... every big tender is given to Indian families ... they are the ones who own everything strategic here in KZN.

We don't have a problem: We are saying share with our people.

We also want to call upon our fellow Indians here in Natal to respect Africans, they are ill-treating them. We don't want that to continue here in Natal. They are treating them worse than Afrikaaners will do.

This is not an anti-Indian statement, it's the truth. If we tell whites the truth; if we tell blacks the truth, we can as well tell Indians the truth. They must treat our people properly here in Kwa-Zulu Natal. ${ }^{27}$

Through a conjunctive reading and an objective, contextual assessment of the statement, the Commission found it not constitutive of hate speech. A further disjunctive reading also found the statement not to be hate speech. ${ }^{28}$

The third statement was the singing of the song 'kiss the boer' (a rewording of the song 'kill the boer') by Julius Malema on 21 March 2018. The Commission interestingly found that the singing of this song does not amount to hate speech, on an objectively construed meaning of the words of the song, from a factual and political perspective. ${ }^{29}$ The Commission found this notwithstanding a contradictory finding of the Equality Court on the same song a few years back. ${ }^{30}$

The fourth statement was made by Julius Malema on 16 June 2018 was also found not to constitute hate speech from an objective and contextual reading; ${ }^{31}$ it read as follows:

We were not all oppressed the same. Indians had all sorts of resources Africans didn't have, Coloureds as well... The majority of Indians hate Africans. The majority of Indians are racist. I'm not saying all, I'm saying majority. ${ }^{32}$

The fifth statement was a social media post made by Mr Godrich Gardee in which he called a fellow DA Member of Parliament, Mmusi Maimane, a 'garden boy' during a parliamentary sitting in May 2018. ${ }^{33}$

26 As above

27 The SAHRC Report (n 2) 20 - 22.

28 As above.

29 The SAHRC Report (n 2) 24.

30 The SAHRC Report (n 2) 22 - 26.

31 The SAHRC Report (n 2) p $26-28$.

32 As above.

33 The SAHRC Report (n 2) 27. 
From a contextual and objective reading, the court also found this statement as not constituting hate speech. ${ }^{34}$

\section{Critical analysis of hate speech as considered in the Report}

\subsection{Critical Race Theory}

As stated above, my critical analysis of the Commission's report will be done by way of CRT). Although my understanding and application of CRT will be mainly founded on Derrick Bell's article 'Who's afraid of Critical Race Theory', 35 it is also influenced by two of Modiri's texts on this theory. ${ }^{36}$

CRT is a field of study that produces mechanisms to critically analyse the dynamics of race and racism within a legal system. ${ }^{37}$ The idea that white supremacy is a far right ideology in as much as the actions of white extremists and the occasional uttering of racially derogatory terms or statements is central to CRT. Racism, for a Critical Race theorist, is a consequence of white supremacy. White supremacy is the structural composition of a society that systematically prejudices black people in a variety of ways for the benefit and conservation of white privilege. ${ }^{38}$ Racism is thus a consequence of the preservation of white privilege.

Modiri situates CRT in a 'post'-apartheid South African context. He then suggests three mains ideals for it within this context. It should firstly be critical of the law and existing legal institutions that sustains white supremacist dogma. It should further analyse the legally crystalised economic inequality, poverty and distribution of wealth along racial lines. It should lastly dwell in the complexities of race, culture and identity of social and political life in South Africa. ${ }^{39}$ It is therefore necessary that CRT, according to Modiri, should be equally as anti-racist as it is anti-capitalist since the two-function hand-inhand. Lastly, Modiri suggests that CRT can be utilised as a postapartheid jurisprudence. ${ }^{40}$

What follows now is a CRT critique of hate speech as considered in the Commission's report on Julius Malema. I will first critique the

34 The SAHRC Report (n 2) 17 - 30.

35 Bell (n 4) $893-910$.

36 Modiri (n 13) 224. See also J Modiri 'Race realism and critique the politics of race in AfriForum v Malema in the (In)Equality Court' (2013) 130(2) SALJ $274-293$. See also J Modiri 'The colour of law, power and knowledge: Introducing Critical Race Theory in (Post-) Apartheid South Africa' (2012) 28 SAHRJ 405 - 436.

Bell (n 4) 901 - 902. See also Modiri (n 36) 285 \& 286.

38 Bell (n 4) 901 - 902. See also Modiri (n 36) 288.

39 Modiri (n 13) 258.

40 Modiri (n 36) 405 - 437. 
two provisions that hate speech is grounded on namely, freedom of expression and equality. I will then critique hate speech as defined in section 10 of PEPUDA. Lastly, I will critique certain terms and judgments referenced in the report.

\subsection{Critique}

In paragraph 2.1.4 of the Commission's report the case of Khumalo $v$ Holomisa was referenced in stating that when a matter of hate speech considered a balance between Freedom of Expression and Equality ought to be established. ${ }^{41}$ Freedom of expression is founded in section 16(1) of the Constitution, which holds the following:

Everyone has the right to freedom of expression, which includes -

(a) freedom of the press and other media;

(b) freedom to receive or impart information or ideas;

(c) freedom of artistic creativity; and

(d) academic freedom and freedom of scientific research. ${ }^{42}$

The Commission's report further states that political speech is central to the freedom of expression, while other types of speech falls in the realm of the abstract in the sense that, it has less societal value and can therefore be easily limited as was the case in De Reuck v Director of Public Prosecutions. ${ }^{43}$ It is clear from the above that freedom of expression is only helpful from a CRT perspective to the extent that it can create awareness of the substantive condition of the black oppressed. $^{44}$ that:

Equality is founded in section 2 of the Constitution and it holds

(1) Everyone is equal before the law and has the right to equal protection and benefit of the law.

(2) Equality includes the full and equal enjoyment of all rights and freedoms. To promote the achievement of equality, legislative and other measures designed to protect or advance persons, or categories of persons, disadvantaged by unfair discrimination may be taken.

(3) The state may not unfairly discriminate directly or indirectly against anyone on one or more grounds, including race, gender, sex, pregnancy, marital status, ethnic or social origin, colour, sexual orientation, age, disability, religion, conscience, belief, culture, language and birth.

41 The SAHRC Report (n 2) para 2.1.4. See also Khumalo v Holomisa [2002] ZACC 12; 2002 (5) SA 401.

$42 \mathrm{Sec}$ 16(1) of the Constitution of the Republic of South Africa, 1996.

43 The SAHRC Report (n 2) para 2.1.4. See also De Reuck $v$ Director of Public Prosecutions (CCT5/03) [2003] ZACC.

44 S Conradie 'Critical Race Theory and the question of safety in dialogues on race' (2016) 36(1) Acta Theologica 5 - 26. See also G Barrie 'Freedom of expression and campus protests' (2017) 38(3) Obiter 623 - 631 . 
(4) No person may unfairly discriminate directly or indirectly against anyone on one or more grounds in terms of subsection (3). National legislation must be enacted to prevent or prohibit unfair discrimination.

(5) Discrimination on one or more of the grounds listed in subsection (3) is unfair unless it is established that the discrimination is fair. ${ }^{45}$

From a CRT perspective, the above quoted equality clause in the Constitution can be said to merely exist for the protection and interest of white privilege and insofar as it seeks to protect black people against the 'injustices of the past,' it does so on a superfluous, abstract level that is merely contingent on the underlying substantive unequal conditions of black people, as will be discussed below. ${ }^{46}$

Kok observes the development of the Constitutional Court's equality jurisprudence as peculiar. He argues that because courts function on a complaint-driven system, black people, as the ones that ought to benefit from equality laws, in light of South Africa's past, do not necessarily benefit from equality laws for an array of reasons. ${ }^{47}$ One being the inability of black people to gain access to the courts as they cannot afford the legal fees. ${ }^{48}$ This argument further contributes to the abstract nature of the courts themselves in the daily experiences of black people. Another question this raises is whether equality laws were in fact enacted for the benefit of black people. Dlamini highlights the potential to mislead this clause has, as it does not necessarily entail total equality or equality in any form for that matter, but rather the idea of fairness and justice which is more related to dignity, which all are very abstract concepts to a significant extent. ${ }^{49}$ This is not to say that fairness, justice and dignity will not aid black people in the quest for economic emancipation, but it does not speak to the core issue of substantive inequality, poverty and material living conditions. ${ }^{50}$

In section 2(1) of the Constitution above, it states that 'everyone is equal before the law', however, from the perspective of CRT the wording of this section is very peculiar in the sense that it does not mirror the reality of racial inequality. ${ }^{51}$ One can thus deduce from this that despite the reality of racial inequality, in the eyes of the law black and white people are seen as equal. This proves that the law and the equality clause in particular is very much detached from reality, as its conception of equality roams in the abstract domains of justice

Sec 9 of the Constitution (n 43).

Bell (n 4) 901 - 902 \&906. See also Modiri (n 37) 275. See also The Preamble of the Constitution (n 43).

Kok (n 11) 133.

As above.

Dlamini (n 12) 14 - 25.

Modiri (n 13) 246.

Modiri ( $n$ 36) 246. See also S Veitch et al (eds) Jurisprudence - Themes and Concepts 2ed. (2012) $123-131$. See also sec 9(1) of the Constitution (n 43). 
and fairness despite the substantive differences in the living conditions of people, the people it seeks to protect. The further wording of 'enjoyment and protection of rights' can be interpreted to the benefit of white interest as black people generally don't have a lot of substantive rights to be protected or enjoyed. ${ }^{52}$ The words in section 2(2) that certain people are to be advanced should therefore be taken very seriously and interpreted in light of black people, amongst others, needing to be substantively advanced out of the position of the unequal. 53

The wording of section 2(3) to (5) of the Constitution also places a negative obligation on the state with regard to equality and this, to a critical race theorist, can be construed as a non-interference with the status quo; the status quo being the substantive inequality of black people. The critique of non-interference with the unequal status quo is substantiated by this clause not placing a positive obligation on the state or on people to actively see that the substantive inequality amongst people be addressed and redressed. ${ }^{54}$

Thus, on careful reflection, the requirement that a balance between the abstract notion of freedom of expression and the abstract notion of equality should be found when considering a matter of hate speech, concludes in hate speech being abstract. I do not argue that hate speech should not be outlawed. I do argue however that if the purpose of hate speech laws is to achieve equality, then the substantive unequal realities of people should be addressed and not the hate speech, which is merely a manifestation of the former. It is here where the ideas of Butler find applicability:

The utterances of hate speech are part of the continuous and uninterrupted process to which we are subjected, an on-going subjection (assujetissement) that is the very operation of interpellation, that continually repeated action of discourse by which subjects are formed in subjugation. Those offensive terms that mark out a discursive place of violation precede and occasion the utterance by which they are enacted; the utterance is the occasion for the renewal of that interpellating operation. Indeed, that operation is only instanced by the 'verbal conduct'; but the operation of interpellation happens with or without such conduct.

The responsibility of the speaker ... [consists in] negotiating the legacies of usage that constrain and enable that speaker's speech. ${ }^{55}$

From the above quotation I note that even in its abstractness, hate speech is only useful insofar as it illustrates that the "hearts and

$52 \operatorname{Sec} 9(1)$ of the Constitution (n 43).

53 As above.

54 Bell (n 4) 906. See also Modiri (n 36) 281. See also secs 9(3)-(5) of the Constitution (n 43).

55 J Butler 'Excitable speech: A politics of the performative' (1997) 127. See also Modiri (n 37) 280. 
minds" of people in the society are not yet transformed; real transformation vests in the underlying substantive conditions which enable hate speech.

What hate speech laws also do is create the perception that racism and discrimination are isolated incidents. It has already been stated that racism and discrimination is embedded in the functioning of a white supremacist society. ${ }^{56}$ It has also been stated that for CRT, 'post'-apartheid South Africa is such a society as white privilege and interests are protected to the detriment of the black oppressed. It has further been stated that racism is a consequence of white supremacy and although hate speech is not synonymous with racism (systematic racism at least), a racial slur can constitute hate speech if it meets the requirements of section 10 of PEPUDA. ${ }^{57}$

When looking at the objective test (paragraph 4.4 of the report), the debate between disjunctive or conjunctive (paragraph 4.2.1) and the necessity for context (paragraph 5), the interpreter be it a judge or a commissioner will then come to the conclusion that a certain statement does or does not constitute hate speech as seen in the report. ${ }^{58}$ Racial slurs are also commonly seen as acts of racism. ${ }^{59}$ Therefore, in identifying certain acts of racism as hate speech, it alludes to the idea that acts of racism can be identified and isolated. This idea that hate speech can be identified and isolated gives light to a narrow view of racism which is contrary to the CRT view that racism is systemic inequality. ${ }^{60}$ This narrow view of racism is thus abstract in the sense that it does not address the systemic inequality wherein racism vests itself.

This leads to hate speech being very individualistic whereas inequality and racism is more systemic as explained. ${ }^{61}$ In isolating a certain instance or statement of racial hate speech one inevitably implicates a certain individual or group of individuals as wrongdoers. The concept of hate speech also implies that both black and white people can be racist, in instances where hate speech is made in a racial context of course. This is the subject matter of statements four and five, (in paragraphs 10.2 and 11.5 ) of the report. ${ }^{62}$ From a CRT perspective racism is not defined by utterances therefore, certain 'wrongdoing individuals' cannot be found guilty of racism as racism exists within a broader system of a society functioning under white

56 Modiri (n 36) 288. See also Kok (n 11) 133.

57 The SAHRC Report (n 2) 4.

58 As above.

59 J Modiri 'The "event” of racism' Daily Maverick 17 November 2016 https://www. dailymaverick.co.za/opinionista/2016-11-17-the-event-of-racism/ (accessed on 16 September 2019).

60 Bell (n 4) 901 - 906. See also Modiri (n 37) 284 \& 288.

61 As above. See also Modiri (n 3) 225.

62 The SAHRC Report (n 2) 10. 
supremacy. The utterer and the utterance for CRT is irrelevant, as it is the broader system that needs change. ${ }^{63}$

In paragraph 4.8 it states that section 10 of PEPUDA requires an objective test to establish hate speech. It further goes on to say that objectivity is determined through 'reasonableness'. ${ }^{4}$ The legal concept of 'reasonable', as pointed out by Modiri, is problematic through the lens of CRT since it alludes to the idea of the reasonable man being the heterosexual, white male. ${ }^{65}$ Everything that would pass as reasonable would therefore be the thoughts and experiences that the heterosexual white male deems fit.

Interestingly, in paragraph 9.3.5 the Commission also references this extract by Modiri. The Commission does so when it establishes the requirement of objectivity and context and thus critiques the judgment of Afriforum $v$ Malemastating that 'how the black majority views the song (kiss the boer) should also be interpreted to constitute what the court sees as reasonably' ${ }^{66}$ It is my understanding that the Commission does not apply Modiri's critique of reasonableness properly, as the Commission's request alludes to the black majority's perspective to be assimilated into the already white perspective of reasonable. This type of assimilation would also be rejected by CRT as it alludes to the racist idea that blackness needs to be assimilated into whiteness. ${ }^{67}$

In paragraph 5.6 and 7.1.2.2 of the report the Commission draws reference to the case of Hotz $v$ University of Cape Town where it is stated that:

Where the offender of hate speech belongs to a vulnerable group [...] [f]reedom of speech must be robust and the ability to express hurt, pain and anger is vital, if the voices of those who see themselves as oppressed or disempowered are to be heard. ${ }^{68}$

I have already discussed the issue of racism not being able to be committed by both black and white people, since racism is a consequence of the larger socio-economic inequality in a white supremacist society. ${ }^{69}$ However, the above quotation further illustrates hate speech in its abstract nature. On a superficial level, the quotation can be seen as being empowering towards vulnerable people (which in the context of this essay is black people) yet on a much deeper level, from a CRT perspective, it shows just how

63 Bell (n 4) 901 - 906. See also Modiri (n 37) 284; Modiri (n 14) 247.

64 The SAHRC Report (n 2) 10.

65 Modiri (n 36) 275.

66 The SAHRC Report (n 2) 10. See also Afriforum v Malema 2011 (12) BCLR 1290 (EqC) 39.

67 Bell (n 4) 901 - with an emphasis on 'empower'. See also Modiri (n 36) 284; Modiri (n 13) 225.

68 The SAHRC Report (n 2) 16. See also Hotz v University of Cape Town 2019 (1) SA 369 (CC).

69 Bell (n 4) 901 - 906. See also Modiri (n 36) 288; Modiri (n 13) 233. 
detached hate speech is. The above quotation implies that some people are vulnerable and some are not and this is therefore evidence of racial inequality. Therefore, instead of equality jurisprudence dealing head on with this inequality, hate speech deals with the anger people feel as a result of the much deeper substantive inequality. What the above quotation in essence does is state that the courts should aid people in finding solace in their 'unfreedom-ness' by allowing them to express anger towards the group that oppresses, instead of dealing with the oppression itself. ${ }^{70}$

In paragraph 5.5 of the report, the commission references the case of SARS V CCMA which states that:

It can never be over-emphasised that being called a kaffir is the worst insult that can ever be visited upon an African person in South Africa, particularly by a white person' (emphasis added). ${ }^{71}$

This was said in the context of the Commission illustrating that the identity of both the offender and the target is of importance. From the perspective of CRT one cannot deny that the use of the k-word is an insult insofar as it denotes inferiority to one race and superiority to another. ${ }^{72}$ To say that it is the worst possible insult is a denial of the underlying substantive inequality that gives effect to the supposed inferiority and superiority. Substantive inequality is the essence of white supremacy. Thus from a CRT perspective one would say the very existence of white supremacy is the worst possible insult towards black people. ${ }^{73}$ This is another example of the court's narrow interpretation of racism.

In CRT, the argument is that racism is the systemic, political, economic and social oppression of black people under a system that seeks to promote white privilege and interests i.e white supremacy. Therefore, if black people are not systematically oppressed in a political, economic and social manner for white privilege then racism ill not exist. Race-based hate speech, as a consequence of systemic racism, would also be obsolete. The proposal therefore is to address the substantive inequality of black people instead of addressing hate speech which is merely a concomitant issue. ${ }^{74}$

70 As above.

71 The SAHRC Report (n 2) 16.

72 Bell (n 4) 906. See also Modiri (n 36) 286; Modiri (n 13) 230.

73 Bell (n 4) 901. See also Modiri (n 36) 288; Modiri (n 13) 261.

74 As above. 


\section{From the perspective of Transformative Constitutionalism}

According to Klare, the South African Constitution can be regarded as a post-liberal document in order to distinguish it from a social democratic document, since to Klare, the term 'social democratic' is too narrow an interpretation when one looks at the Constitution's recognition of different races, cultures, genders and languages. ${ }^{75}$

Transformative Constitutionalism entails the long-term development of constitutional jurisprudence parallel to political developments that will result in effective social change. ${ }^{76}$ For Klare, Transformative Constitutionalism is a method that can be utilised by the judiciary to interpret the Constitution in such a way as to give effect to societal change. 77 This notion of Klare's is influenced by Critical Legal Studies which amongst other things, holds the view that the law and politics cannot be separated and that judges make political decisions all of the time. ${ }^{78}$ Judges should therefore be conscious of the political consequences of their decisions. ${ }^{79}$ Transformative Constitutionalism believes that the Constitution can indeed be a tool for societal change. ${ }^{80}$ The Commission's report and the concept of hate speech (in light of a post-apartheid South Africa) can thus be seen as transformative for a variety of reasons. The first, assuming that the Commission falls within the judiciary as a quasijudicial body and that commissioners acted as adjudicators, the report can be regarded as having been acutely aware of its potential political effects, as Klare argues this essential for transformative adjudication. ${ }^{81}$ The report also set out to protect the black oppressed, or vulnerable groups in recognising that whatever recommendation they make with regard to hate speech would have far more reaching effects beyond the matter at hand. ${ }^{82}$ The Commissioners also disagreed with the Afriforum $v$ Malema case as the judgment was, according to them, too positivist and narrow and therefore not a more transformative view on hate speech. ${ }^{83}$

It has been stated that post-apartheid South Africa, by extension the Constitution, is the political liberation of black people. ${ }^{84}$ Political rights that aim to empower black people, or at least vulnerable

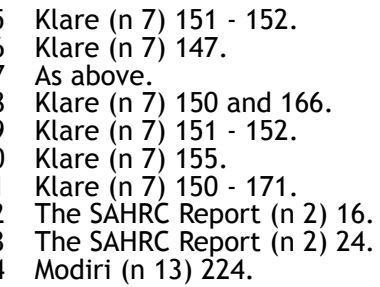


people, are thus seen as transformative. When considering a matter of hate speech, it is stated that one needs to find a balance between freedom of expression and equality. Klare says that the Constitution offer substantive rights and places a positive obligation on the state, ${ }^{85}$ but this is not true for section 2 of the constitution specifically and it is this clause which is the empowering provision for section 10 of PEPUDA, the hate speech clause. All of the aforementioned has been critiqued as political, abstract and detached from the substantively unequal living and working conditions of black people.

Section 3(3) of PEPUDA is another example of how hate speech can be regarded as transformative to a transformative constitutionalist. This section requires, much like transformative constitutionalism, that one considers the historical, social and factual context when adjudicating or presiding over a matter of hate speech. Klare also references these extra-judicial tools for a transformative adjudicator. 86

Thus, although hate speech can be commended as a transformative measure to deal with the scourge of racial and derogatory remarks. It does not do much in changing substantive inequality and this unfortunately goes hand-in-hand with what I believe to be the limits of Transformative Constitutionalism. Merely seeing the law as political ${ }^{87}$ denies it, its socio-economic and substantive racial implications. Murungi states that economic dimensions ought to be recovered in a jurisprudence that aims to truly address the emancipation of black people. ${ }^{88}$

\section{From the perspective of decolonisation}

Decolonisation goes much further than Transformative Constitutionalism in its aspirations to address the legacies of colonialism. Thus, when Klare says that Transformative Constitutionalism goes beyond reform but stays short of a revolution, ${ }^{89}$ it is my understanding that decolonisation goes beyond a revolution. 90

Kwasi Wiredu tells us that conceptual decolonisation is the elimination of certain thinking patterns in our minds that have been imposed on us through the process of colonisation rather than our own reflections on life. ${ }^{91}$ Decolonisation is thus a process of unlearning,

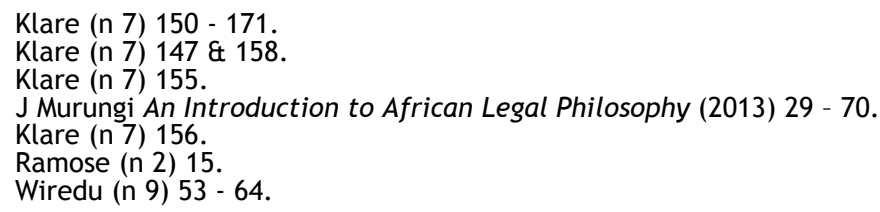


self-consciousness and re-alignment of our conceptual frameworks towards a more African outlook. ${ }^{92}$ Tsenay Serequaberhan's view of African Philosophy as a practice of resistance can also be read as a form of decolonisation in that he requires an indigenous reorientation of philosophical work, a critique of Eurocentrism and the question of our generic identity. ${ }^{93}$

From the perspective of Decolonisation one should be very critical of the Constitution and its ability to transform the South African society, regardless of its interpretation and regard as a Eurocentric document. ${ }^{94}$ I submit that the South African Constitution can be regarded as a Eurocentric document if one looks at the founding values (like equality, which is at the heart of hate speech) and the nature of the fundamental rights it contains.

The founding values of the Constitutional are equality, freedom and dignity. ${ }^{95} \mathrm{~A}$ reading of Bhengu reveals that these three founding values of our Constitution stem from the western philosophical view that one is born a human and therefore deserving of equal treatment, freedom and dignity. ${ }^{96}$ These concepts are also typical of a proWestern individualistic nature, much like hate speech (as has been already critiqued). ${ }^{97}$ The aforementioned is contrary to the African Philosophical notion that one becomes a human through communal interactions. ${ }^{98}$ Further substantiation for the Eurocentricity of the Constitution which gives rise to the concept of hate speech, is that some of the fundamental rights in the Constitution are also similar to those proposed by the western philosopher John Locke which are life, liberty and property. ${ }^{99}$

Furthermore, a possible reason for the abstract nature of equality, and in turn hate speech, would be the narrow view of what constitutes a human being in the western world; the Aristotelian notion that 'man is a rational animal'. ${ }^{100}$ This in turn was not only the basis of the west's conquest of Africa but it also led to a narrow concept of rights as it was deemed that since humans are rational they are to have a very abstract relationship with their environment. The aforementioned is also contrary to the African Philosophical notions of what constitutes a human being. ${ }^{101}$

92 Wiredu (n 9) 55.

93 Serequaberhan (n 9) 44 - 50.

94 As above.

95 The Preamble of the Constitution (n 42).

96 Bhengu (n 14) 4.

97 Modiri (n 36) 406.

98 Ramose (n 1) 12.

99 J Powell 'John Locke: Natural rights to life, liberty and property' 1 August 1996 https://fee.org/articles/john-locke-natural-rights-to-life-liberty-and-property/ [accessed on 26 May 2019].

100 Ramose (n 1) 3.

101 Ramose (n 1) 3 \& 11. 
For a jurisprudence of substantive equality, we would have to decolonise how we perceive human beings and their relationship to their environments. African jurisprudence offers a fundamentally different view on what constitutes a human. If one looks at the concept of Ubuntu we see that one only becomes a human by being a part of something bigger namely, an already existing and continuing communal life that takes into account the living, the living dead and the yet to be born, as Ramose puts it. ${ }^{102}$ It is also from this concept of Ubuntu that the idea is put forth that justice always manifests itself in the concrete world. ${ }^{103}$ Equality would thus be seen in the substantive relations between human-beings. ${ }^{104}$ This is the 'indigenous re-orientation' that Serequaberhan aspires towards in African Jurisprudence. ${ }^{105}$

When reading what the above scholars say about decolonisation and comparing it to what Klare says about Transformative Constitutionalism, one can conclude that Decolonisation is much more a method for reform then merely a theory. An example to this would be the concept of 'reasonableness': the legal requirement for objectivity. 'Reasonableness' has already been critiqued in this essay. Notwithstanding, a Transformative Constitutionalism approach, as had been adopted by the Commission in the report, would assimilate the black majority's perspective into the objective reasonable perspective which is white and Eurocentric. ${ }^{106} \mathrm{~A}$ Decolonisation approach would however do away with the requirement of reasonableness altogether and replace it with a concept like Ubuntu (not the narrow interpretation of Ubuntu that the court follow, but the one as defined by Ramose). ${ }^{107}$

Decolonisation, much like CRT, is more concerned with the root cause of racial inequality, which is colonisation, eurocentrism and white supremacy. ${ }^{108}$ While hate speech laws, even if interpreted through Transformative Constitutionalism, aim to remedy the consequences of racial inequality. The aforementioned can largely be attributed to a narrow interpretation of racism. ${ }^{109}$

102 Ramose (n 1) 4 - 10.

103 Ramose (n 1$) 3$.

104 Ramose (n 1) 3 - 13.

105 Serequaberhan (n 9) 44 - 50.

106 Ramose (n 1) 3.

107 Wiredu (n 9) 53-64. See also Serequaberhan (n 10) 44 - 50.

108 Ramose (n 1) 11 - 13.

109 Ramose (n 1) 13. 


\section{Conclusion}

In conclusion, equality jurisprudence is essential in South Africa, which is said to be the most unequal country in the world. ${ }^{110}$ Section 10 of PEPUDA and the to-be-promulgated Hate Speech Bill form part of South Africa's equality jurisprudence. In this work I have shown, through CRT, that hate speech is an abstract concept within equality jurisprudence. I have shown how Transformative Constitutionalism buys into this abstract notion of equality. I have also shown how decolonisation can be utilised for a more substantive equality jurisprudence.

It is not the intention of this article to brush aside the concept of racially motivated hate speech as frivolous. This article instead aims to critique hate speech as it is considered by the Commission. This article highlights that an effective equality jurisprudence does not fall victim to a narrow interpretation of racism and an abstract notion of equality. An effective equality jurisprudence rather encapsulates a much broader view of racism as systemic and would thus aim to change the lives of black people in a more substantive, concrete and material way.

110 K Pomerantz 'The story behind TIME's cover on Inequality in South Africa' (2 May 2019) https://time.com/5581483/time-cover-south-africa/ (accessed on 16 September 2019). 


\section{A CRITICAL RACE FEMINIST READING OF THE SOUTH AFRICAN PROPERTY LAW}

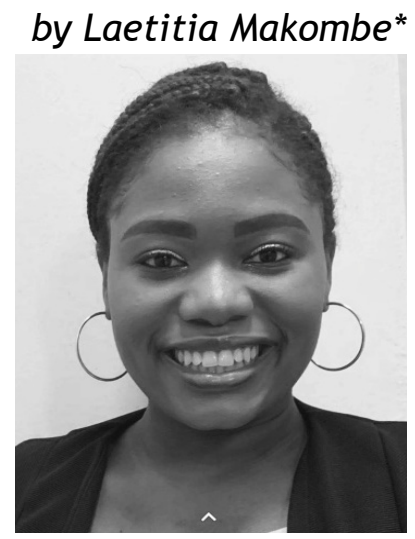

'I can do all things through Christ which strengtheneth me.'

(Philippians 4:13)

\section{Introduction}

The European colonial invasion that birthed apartheid rule resulted in black women being the most vulnerable group to land dispossession. ${ }^{1}$ This vulnerability has been exacerbated by the ineffective measures of the law that, in an attempt to redress these past injustices, fail to afford adequate recognition to the racial, gender and socio-economic marginalisation of black women in the regulation of land issues. ${ }^{2}$ This essay essentially aims to highlight the intersectionality between the oppressions of gender, racial and class based discrimination, which black women in South Africa are afflicted by in relation to land ownership and the security of land tenure. This essay further

* Third year LLB student, University of Pretoria, 2019. Many thanks to Dr Joel Modiri for the insightful comments, Mr Mzwandile Ngidi (my editor) as well as Mr Tumelo Manare for all the cordial support and great assistance. I would also like to extend my gratitude towards Dr Mary Bushiri as well as my biological parents, Donald and Shalon Makombe for the infinite love and inspiration towards my legal studies.

1 South African History Online 'Land: dispossession, resistance and restitution' 26 March 2013 https://www.sahistory.org.za/topic/land-act-dispossession-segre gation-and-restitution (accessed 18 May 2019).

2 K Crenshaw 'Demarginalizing the intersection of race and sex: a black feminist critique of antidiscrimination doctrine, feminist theory and antiracist politics' (2015) 1989 University of Chicago Legal Forum at 141. 
illuminates how there is a crucial necessity for the decolonisation of the South African property law system as a whole, in order to address the problem of black women being the most vulnerable group to land dispossession in this democratic era.

This evaluation is conducted by providing a critique of the Extension of Security of Tenure Act 62 of 1997 ('ESTA') in light of the Critical Race Feminist theory and with reference to various South African case law, in order to expose how issues of race, gender and class intersect within the context of land dispossession. Moreover, the essay progresses to explain the manner in which the interpretation of the South African property laws such as ESTA, positively transform legal knowledge. It should be noted that the legal transformation is not enough to address a dispossession of land from black women. Consequently, this essay argues that what is necessary in a South African context is the entire decolonisation of the property law system, which can serve as the appropriate measure for remedying the vulnerability of black women to land dispossession in this post1994 era.

\section{ESTA as well as the Klaase and Hattingh cases}

It should be pointed out that ESTA aims to provide measures that facilitate the long-term security of tenure of residents who occupied a landowner's land after 4 February $1997 . .^{3}$ It does this through regulating the conditions of residence and eviction pertaining to land occupation with the main objective of affording female occupiers the same rights as male occupiers. ${ }^{4}$ Effectively, ESTA was promulgated to extend the constitutional right to property as stipulated in section 25(6) of the South African Constitution. ${ }^{5}$ Accordingly, ESTA seeks to protect the security of tenure of both male and female occupants, in order to address the problem of increased unlawful evictions of farm dwellers from the landowner's tenure. ${ }^{6}$

The Klaase case addresses whether a female seasonal worker who is a spouse of a permanent farmworker constitutes an 'occupier' in terms of section $9(2)$ of ESTA. ${ }^{7}$ In order to avoid eviction and secure land tenure upon the termination of her husband's employment, Mrs Klaase, the applicant, contended that she qualified as an occupier in

3 Secs 2(1) \& 8 of the Extension of Security of Tenure Act 62 of 1997.

4 PASSOP 'Housing Rights (ESTA)' 2013 https://www.passop.co.za/your-rights/ housing-rights-esta (accessed 18 May 2019).

5 The Constitution of the Republic of South Africa, 1996.

6 A October 'Farm battlegrounds: between the land and the law' Daily Maverick 3 April 20191 https://www.dailymaverick.co.za/article/2019-04-03-farm-battle grounds-between-the-land-and-the-law/ (accessed on 19 May 2119).

7 Klaase and Another $v$ van der Merwe N.O. and Others 2016 (6) SA 131 (CC) para 8 ('Klaase'). 
terms of ESTA. ${ }^{8}$ The applicant argued that despite having no express consent of occupation from the respondent, her contract of seasonal employment on the farm entitled her to become an 'occupier' who was subject to the protection of land tenure measures as provided by ESTA. ${ }^{9}$ On the contrary, the respondents submitted that the failure to be a permanent employee on the farm disqualified Mrs Klaase from being an 'occupier' in terms of ESTA. ${ }^{10}$ The Constitutional Court, after concluding that the applicant qualifies as an occupier in terms of $s 9(2)$ of ESTA, ruled that the applicant's eviction was unlawful because ESTA facilitated the security of tenure relating to both seasonal and permanent farmworkers. ${ }^{11}$

In the Hattingh case, the applicants were family members of Mrs Hattingh, an elderly poor coloured woman residing on the respondent's land in terms of section 1 of ESTA. In this case, the applicant sought an appeal against an order of eviction issued by the Land Claims Court. ${ }^{12}$ The applicants argued that they were entitled to remain in occupation of the land with their mother, despite the death of their father who was employed by the respondent, because section 6(1) of ESTA entitled their mother the right to a family life. ${ }^{13}$ Conversely, Mr Juta who was the respondent contended that Mrs Hattingh and her family should have been evacuated from his premises because he wished to utilise the cottage to accommodate his new farm manager. ${ }^{14}$ The Constitutional Court judges ruled that although section 6(2) of ESTA entitles Mrs Hattingh the right to family life, there must be a balance between the occupants' right to family life and the rights of the landowner. ${ }^{15}$ Therefore, in this case, ordering the eviction of the applicants would result in the just and equitable balance of the respondent's rights as a landowner with those of the applicants. ${ }^{16}$

\section{The significance of the interpretation of ESTA in Hattingh as well as Klaase}

The Klaase case plays an important role in cognisance of the fact that ESTA aims to secure land tenure for both men and women as discussed above. ${ }^{17}$ This is because the Klaase case serves as an illustration of how the occupational inferiority of black female farmworkers further

8 The Klaase case (n 7) para 18.

9 The Klaase case (n 7) paras 57 \& 61.

10 The Klaase case (n 7) para 17.

11 The Klaase case (n 7) paras 62- 65.

12 Hattingh and Others v Juta 2013 (3) SA 275 (CC) para 1 ('Hattingh').

13 The Hattingh case (n 12) paras 9-11.

14 The Hattingh case (n 12) paras 12-13.

15 The Hattingh case (n 12) paras 32-41.

16 The Hattingh case (n 12) paras 42-44.

17 October (n 6). 
contributes towards the vulnerability of land dispossession for black women in this post-apartheid era. ${ }^{18}$ The Klaase case illustrates this by highlighting that despite the favourable judgement that ruled that Mrs Klaase qualified as an 'occupier' that should be protected by ESTA, black female farmworkers who fail to obtain a written contract of seasonal employment are still in danger of being subject unlawful evictions. ${ }^{19}$ In addition, the Hattingh case greatly signifies that property laws such as ESTA that seek to secure land tenure can have a limited scope of application when balancing the interests of the occupier with those of the landowner. ${ }^{20}$

\section{The failures of ESTA in light of Critical Race Feminism}

The Critical Race Feminism (CRF) theory derives its origins from diverse feminist legal theories, critical legal studies as well as the Critical Race Theory (CRT). ${ }^{21}$ Wing describes it as an;

[An] embryonic effort in legal academia that emerged at the end of the twentieth century to emphasize the legal concerns of a significant group of people those who are both women and members of today's racial/ ethnic minorities, as well as disproportionately poor. ${ }^{22}$

This description enables us to comprehend that the main objective of CRF is to expose and address the intersectionality in the gendered, racial and class marginalisation and suppression of black women in society. ${ }^{23}$ CRF theory contends that black women are subject to the most prejudicial oppression in society as they are discriminated against because of being black, female as well as being categorised under the lowest class in society. ${ }^{24}$ Prominently, a decolonisation approach that centralises CRF in the creation of laws regulating the South African property system such as ESTA, is a crucial prerequisite for the alleviation of black women's vulnerability to the land dispossession problem, which dominates in this post-1994 era. ${ }^{25}$

As Modiri explains, CRF is a theory that focuses on antiessentialism and intersectionality as it was born out of the idea that

18 The Klaase case (n 7) paras 55 - 63.

19 October (n 6).

20 The Hattingh case (n 12) paras 42 - 44.

21 N Carter 'Critical Race Feminism: An educational perspective' (2012) 4 PowerPlay at 3.

22 AK Wing Critical race feminism: a reader (2003) 1.

$23 \mathrm{~K}$ van Marle \& E Bonthuys 'Feminist theories and concepts' in C Albertyn \& E Bonthuys (eds) Gender, law and justice (2007) $40-43$.

24 Van Marle (n 23) 41 - 42.

25 P Madletyana 'Race, gender, class and land reform: a case study approach on the land reform for agricultural development (LRAD) sub-programme' Master's thesis, University of Witwatersrand, 201117 - 31 https://pdfs.semanticscholar.org/ 25db/1a872f4973cb14321876115dd5989ace687e.pdf (accessed on 19 May 2019). 
feminist jurisprudence failed to provide and adequately acknowledge the oppressions of race and gender, whilst on the other hand, the CRT also failed to acknowledge the gender concerns of feminism. ${ }^{26}$ This quote explains that the exclusion of black women's experiences and gender oppressions from the different types of feminist ideas and race theories gave rise to the CRF theory. Importantly, CRF gives an account for the gender, racial and class discrimination which black women are exposed to in their everyday lives. ${ }^{27}$ It is therefore remarkable to note that CRF is often referred to as black feminism, as it broadly utilises the term 'black women' as referring to all women of colour who suffer racial, gender and class discrimination including all African, Asian, Indian as well as the coloured individuals. ${ }^{28}$ According to Wing;

Critical Race Feminism serves as a challenge answer to the invisibility of women of color in laws that are deemed as neutral, and challenges the idea that the law is balanced, when it instead perpetuates race, gender and class hierarchies. ${ }^{29}$

The above statement plays an important role as it highlights both political as well as representational intersectionality in the marginalisation of black women. ${ }^{30}$ Intersectionality refers to the overlapping and intersecting social identities that are related to oppressive, dominant and discriminatory systems that affect and inform how individuals operate in a society, and further work together to construct how others perceive black women in society. ${ }^{31}$ Political intersectionality denotes how the exclusion of the prejudicial experiences from the traditional forms of feminism and antiracist political campaigns have contributed towards the marginalisation of women of colour when dealing with their victimisation. ${ }^{32}$ In addition, representational intersectionality places much emphasis on the ways in which the cultural constructions of black women have greatly influenced the political agendas and creation of legislation such as ESTA, that undermine their prejudicial experiences. ${ }^{33}$

One of ESTA's main objectives is to remedy the problem of land dispossession, which farmworkers are subject to, through affording individuals of colour who qualify as 'occupiers' in terms of this Act,

$26 \mathrm{~J}$ Modiri 'The colour of law, power and knowledge: introducing critical race theory in (post-) apartheid South Africa' (2012) 28 South African Journal on Human Rights at 418.

27 B Hooks Feminism Is for Everybody: Passionate Politics (2000) 55.

28 A Harris \& $Z$ Leonardo 'Intersectionality, race-gender subordination, and education' (2018) 42 Review of Research at 14-16.

29 Wing (n 22) 2 - 3

30 Carter (n 21) 8.

31 B Cooper 'Intersectionality' in L Disch \& $M$ Hawkesworth (eds) The oxford handbook of feminist theory (2016) 5-25.

$32 \mathrm{~K}$ Crenshaw 'Mapping the margins: intersectionality, identity politics, and violence against women of color' (1991) 43 Stanford Law Review at 1242-1247.

33 Crenshaw (n 32) 1245 - 1248. 
the right to security of tenure on the landowner's property with that owner's consent. ${ }^{34}$ Although this serves as a redress mechanism that seeks to facilitate the land tenure of black people, property laws such as ESTA fail to provide adequate protection to black women who are spouses to those who qualify as 'occupiers' in terms of ESTA. ${ }^{35}$ This is because its failure to include the spouses of the 'occupiers' in the ambit of its protection has increased the number of black women who are subject to evictions, subsequently worsening the vulnerability of women to land dispossession in this post-1994 era. ${ }^{36}$ We can therefore investigate that the identification of black women as belonging to the lower class group contributes towards the creation of laws such as ESTA, that fail to place satisfactory emphasis on the need to address the daily struggle of black women pertaining to insecure land tenure problems. ${ }^{37}$ ESTA is established as;

a measure which recognises and provides remedies for the social and economic vulnerabilities faced by farm dwellers through taking the precariousness and fragility of their lives seriously, protecting their tenure, as well as preserving their well-being when an eviction and relocation is unavoidable. ${ }^{38}$

This quote illustrates how ESTA focuses on eradicating social vulnerabilities, including racial and gender discrimination, as well as economic vulnerabilities such as the oppression of the lower working class. ${ }^{39}$ However, ESTA only provides limited remedies in addressing such social vulnerabilities. It could be argued that this is because the Act does not provide redress measures aimed at specifically preventing black women from being unfairly evicted upon losing their employment on the farm or upon the death of their husbands who used to render employment services on the farm. ${ }^{40}$ Subsequently, the failure of black women to benefit from this social and economic security, which laws such as ESTA aim to facilitate, renders black women as members belonging to the working class to be the most vulnerable group that is subject to land dispossession in this democratic era. ${ }^{41}$

Accordingly, it is submitted that ESTA seems to provide male farmworkers with more social and economic protection than female

34 Secs $1 \& 3$ of the Extension of Security of Tenure Act (n 3).

35 Madletyana (n 25) 24.

36 Madletyana (n 25) 25

37 Madletyana (n 25) 16.

38 W Stuart 'ConCourt falls short of farm dweller Act's aims' Mail \& Guardian 19 July 2017 1. https://mg.co.za/article/2017-07-18-concourt-falls-short-offarm-dweller-acts-aims (accessed 18 May 2019).

39 Madletyana (n 25) 21-23.

40 South African History Online 'Land: dispossession, resistance and restitution' 2013 https: / /www.sahistory.org.za/topic/land-act-dispossession-segregation-andrestitution (accessed 18 May 2019).

41 M Hunter \& T Hodgson 'Ms. Elsie Klaase and the Constitutional Court's missing women' (2016) 8 Constitutional Court Review at 284. 
farmworkers. ${ }^{42}$ This may be supported by alluding to the judgement made in the Klaase case where the court disregarded the gender and race of Mrs Klaase, and utilised her seasonal employment contract as the basis to identify her as an 'occupier' in terms of ESTA. ${ }^{43}$ In this case, ESTA was used to accommodate the social and economic vulnerabilities of Mrs Klaase's late husband by using his permanent employment on the farm as a reason to qualify him as an 'occupier'in terms of ESTA. ${ }^{44}$ In doing so, the social and economic vulnerabilities of black women such as Mrs Klaase, which made her prone to land dispossession were worsened, because the majority of seasonal farmworkers were and still remain excluded from the protection of ESTA due to their failure to satisfy the definition of an 'occupier' which is prescribed by ESTA. ${ }^{45}$ Moreover, this further intensifies the degradation of black women in terms of classism, into the lowest class that merely renders labour services to owners of the means of production, who are mostly farm owners. ${ }^{46}$

The preamble of ESTA informs us that one of its goals is to afford both male and female occupiers equivalent redress measures and protection in order to facilitate long-term security of land tenure. ${ }^{47}$ From reading this, we can deduce that ESTA fails to satisfy this objective by alluding to Carter who states that CRF focuses on exposing the intersectionality in the discrimination that black women suffer because of race, gender and class of race, gender and class. ${ }^{48}$ This is because unlike black men who are only victims to racial discrimination, black women are subject to an intersection of gender, and racial discrimination that is influenced by the socio-economic class with which they are identified as belonging to. ${ }^{49}$ Therefore, it is impossible to provide redress and secure land tenure measures that are of equivalent value for both men and women because women are subject to much greater forms of discrimination as compared to men. ${ }^{50}$ Therefore essentially, ESTA fails to serve as an adequate redress mechanism which can alleviate the vulnerability of women to land dispossession in this post-1994 era, as many farmers often invent deliberate and constructive means of evicting female farmworkers who are in occupation of their land. ${ }^{51}$

It is important to understand that ESTA fails to provide adequate redress measures that can remedy the racial and gender

42 October (n 6).

43 The Klaase case (n 7) paras $55-66$.

44 The Klaase case (n 7 above) paras 3-18.

45 Hunter \& Hodgson (n 41) 297.

46 S Veitch et al Jurisprudence: themes and concepts (2012) 225-227.

47 Preamble of the Extension of Security of Tenure Act (n 3).

48 Carter (n 21) 3.

49 Crenshaw (n 32) 1242-1245.

50 October (n 6).

51 Stuart (n 38). 
subordination that black women are subject to because of belonging to the lower working class in society. ${ }^{52}$ This is because the Act permits the landowner to order the eviction of female farmworkers upon their failure to render employment services irrespective of such failure being caused by circumstances beyond human control, such as aging and illness. ${ }^{53}$ We can find a demonstration of this in the Hattingh case, by observing that the court ordered the eviction of Mrs Hattingh and her family from the landowner's farm due to her inability to render her labour services as she had become old. ${ }^{54}$ This further perpetuates the socio-economic vulnerability of women in society and they are further ranked as the lower class individuals. It can be argued that this is because the court failed to take into account that Mrs Hattingh was an elderly woman who has shown much dedication in working on the farm during her young age, and is now in need of a family that could provide physical, financial and emotional assistance, as well as a secure land tenure. ${ }^{55}$ Consequently, this subjects black women to unfair evictions that also dispossess the security of their land tenure. ${ }^{56}$

We can argue that ESTA fails to centralise the CRF ideas that seek fair and just practices, whilst simultaneously examining and combating oppression relating to gender and race. ${ }^{57}$ This is because despite its failure to enact provisions which specifically address the gender and racial subordination of black women, ESTA further requires the landowner's consent in order to afford any "occupier" in terms of ESTA, the right to dwell on the land. ${ }^{58}$ As a consequence, this can further intensify the vulnerability of black women to land dispossession as most farmworkers often grant tacit, instead of express consent to the spouse of the male farmworker to reside on the farm during the his term of employment on the farm. ${ }^{59}$ This has the effect of worsening the vulnerability of black women to land dispossession as they are often disqualified from accessing the protection measures provided by ESTA due to the lack of obtaining express consent to reside on the land from the farm owner. ${ }^{60}$

Importantly, the failure of ESTA to serve as a redress mechanism that recognises and seeks to remedy the marginalisation of black women because of their gender, race and class inadvertently signifies its inability to address the matrix of domination pertaining to the land dispossession that is suffered by women in this democratic era. ${ }^{61}$ This

52 Madletyana (n 25) 40.

53 Sec 8 of the Extension of Security of Tenure Act (n 3).

54 The Hattingh case (n 12) paras 27-32.

55 The Hattingh case (n 12 paras 34-40.

56 Madletyana (n 25) 41.

57 Carter ( $\mathrm{n}<\mathrm{XREF}>$ above) 3.

58 Sec 3 of the Extension of Security of Tenure Act (n 3).

59 The Klaase case (n 7) para 27.

60 The Klaase case (n 7) paras 49-56. 
is further worsened by ESTA's limited application as explained in section 1 of this Act, which exclusively accommodates individuals residing on farms, in rural areas as well on any land which is undeveloped. ${ }^{62}$ As a result, of this limited application as well as the failure to address the matrix of domination relating to class, gender and race, an increased number of black women are victims of eviction and unfair land dispossession. ${ }^{63}$ Consequently, the vulnerability of black women to land dispossession violates their right to human dignity. ${ }^{64}$

\section{The manner in which an interpretation and application of ESTA in light of the Critical Race Feminist Theory can transform legal knowledge}

According to Carter, 'Critical Race Feminism, which originates from critical legal theory, feminist legal theory, and critical race theory, promises to afford legal and academic stratagem for studying and eradicating race, class, and gender oppression in educational institutions'. ${ }^{65}$ This quotation explains that the CRF is as a result of combining the ideas of racial and gender equality that arise from the feminist and critical race theories. ${ }^{66}$ Therefore, CRF appreciates that although identity politics promises to achieve unity and intellectual development in communities, it often disregards the various forms of oppression, which black women residing in communities are subject to on a daily basis. ${ }^{67}$ By analysing the failures of our property law system, using ESTA as aforementioned, it is deductible that the failure of laws governing our property system to promote the values underlying CRF has the effect of depriving black women access to equal opportunities in society. ${ }^{68}$ This is further supported by the reason that ESTA fails to serve as a public instrument of law that can expose the intersectionality in oppressions of race, gender and class that black women are continuously subject to. ${ }^{69}$ As a result, black women cannot rely on ESTA as a means to obtain secure land tenure because of its failure to represent the intersecting gender, class and racial oppression of black women. ${ }^{70}$ empowerment (2000) 5-25.

62 Sec 1 of the Extension of Security of Tenure Act (n 3).

63 Madletyana (n 25) 40-45.

64 Sec 10 of the Constitution of the Republic of South Africa, 1996.

65 Carter (n 21) 7.

66 As above.

67 Crenshaw (n 32) 1242.

68 Harris \& Leonardo (n 28) 8.

69 Harris \& Leonardo (n 28) 6-10.

70 Carter (n 21 above) 8. 
Legal knowledge refers to the attainment of a deep understanding and conceptualisation of the law as a discipline that encapsulates the ideas of a General and African jurisprudence in society. ${ }^{71}$ General jurisprudence refers to utilising laws such as ESTA to gain legal consciousness through analysing how issues pertaining to identities of class, race, and gender influence the justice of those who are the most vulnerable to land dispossession in society, namely black women. ${ }^{72}$ Adding to this, the principles underlying African jurisprudence, which recognise that Africans are human beings who should have equal access to the law's protection, would also assist in protecting the right to secure land tenure, an entitlement black women are not given full access to by ESTA. ${ }^{73}$ With that being said, one can observe that interpreting ESTA in light of the principles set by the CRF theory enables ESTA to serve as a medium of law that provides for the security of black women's land tenure, and thus alleviate their vulnerability to land dispossession in this democratic era. ${ }^{74}$

Transformation is a social and economic revolution that amongst many other objectives, aims to make provision for an improved access to opportunities and education through making use of diverse means, including affirmative action and redress measures. ${ }^{75}$ This means that redress measures such as the implementation of ESTA should not only aim to improve the security of land tenure of black women, but also serve as an instrument of improving the knowledge of such black women pertaining to their land rights. ${ }^{76}$ Moreover, a decolonising critique of laws regulating our property law system such as ESTA in light of the CRF theory transforms legal knowledge through raising an awareness of the need to implement more radical means that can alleviate the discrimination of black women based on their class, race and gender. ${ }^{77}$ This further transforms legal knowledge through educating individuals about the equal rights and opportunities, which black women ought to obtain in society instead of promoting their marginalisation due to their gender, class and racial identities. ${ }^{78}$ Consequently, this also alleviates the vulnerability of black women to land dispossession in this post-1994 era, in as much as it also protects their right to property. ${ }^{79}$

71 C Douzinas and A Gearey Critical jurisprudence: the political philosophy of justice (2005) 4-5.

72 Douzinas \& Gearey (n 71) 5-7.

$73 \mathrm{R}$ Mogobe 'An African perspective on justice and race' 2001 http:// them.polyog.org/3/frm-en.htm (accessed 20 May 2019).

74 Carter (n 21) 7-9.

75 P Langa 'Transformative constitutionalism' (2006) 17 Stellenbosch Law Review at 352.

76 Langa (n 75) 353.

77 Langa (n 75) 351.

78 Madletyana (n 25) 43-46.

$79 \mathrm{Sec} 25$ of the Constitution of the Republic of South Africa, 1996 (n 64). 
The implementation of ideals underlying CRF into laws that serve as redress methods such as ESTA, is vital for the enrichment of our legal knowledge as explained by Quinot who states that:

[S]ignificantly increased attention to theory (or theories) of legal education is not only imperative in order to improve the quality of legal education in South Africa, but is also a crucial ingredient of constitutional transformation grounded in law in this country. ${ }^{80}$

This can be substantiated by the reason that, raising an awareness of black women's human rights being equal to those of all other individuals in our country does not only assist in educating those involved in legal studies, but it also helps us achieve the outstanding objective of our Constitution, which is healing all wounds of the past and striving to create a better future. ${ }^{81}$ In doing this, the main goal of transformative constitutionalism, which is transforming our society in a manner that upholds and promotes our constitutional values, is achieved through promoting the substantive equality, as well as improving the socio-economic conditions of all individuals, including black women. ${ }^{82}$

In addition to this, the interpretation and application of ESTA in light of the CRF theory can positively contribute towards the process of transformative constitutionalism. This process 'entails the development of opportunities which allow people to realise their full human potential within positive social relationships' and 'requires a complete reconstruction of the state and society, including a redistribution of power and resources along egalitarian lines. ${ }^{83}$ This is because in the process of recognising and addressing the subordination of black women, equal opportunities are developed simultaneously for such women as power is redistributed from the dominant male figures and white supremacy to the lower working class. ${ }^{84} \mathrm{As}$ a result, the interpretation and application of ESTA, in light of CRF, also addresses the main challenge of transformative constitutionalism that 'involves the eradication of systemic forms of domination and material disadvantage based on race, gender, class and other grounds of inequality'. ${ }^{85}$

Be that as it may, it is important to understand that interpreting ESTA in light of the CRF theory could also be used to positively influence legal education through transforming our legal culture. ${ }^{86}$

80 G Quinot 'Transformative legal education' (2012) 129 South African Law Journal at 412 .

81 Quinot (n 81) 413.

82 Langa (n 75) 353-357.

83 Langa (n 75) 352-353.

84 Langa (n 75) 352-355.

85 Langa (n 75) 352.

86 K Klare 'Legal culture and transformative constitutionalism' (1998) 14 South African Journal of Human Rights at 147. 
Langa describes this transformation as shifting from an authoritative culture to:

a culture of justification which is a culture in which every exercise of power is expected to be justified; in which the leadership given by government rests on the cogency of the case offered in defence of its decisions, not the fear inspired by the force of its command; the new order must be a community built on persuasion, not coercion. ${ }^{87}$

This implies that a transformation occurs in the transition from an authoritative system, with Parliamentary sovereignty as was with the case with apartheid South Africa, into a justified system, with Constitutional supremacy, where every exercise of power is justified by valid reasons. ${ }^{88}$ Subsequently, interpreting ESTA in light of the CRF theory, which is influenced by transformative constitutionalism, results in the need for the justification of any reasons explaining why black women are being excluded from the ambit of ESTA's protection in this democratic era. ${ }^{89}$

\section{Decolonising property law to address the vulnerability of black women}

Although an interpretation and application of ESTA in light of CRF promotes a justified legal culture and transformative constitutionalism, it nevertheless fails to address the problem of black women being the most vulnerable group to land dispossession in this democratic era. ${ }^{90}$ This is because even though ESTA aims to serve as a means of securing the land tenure of black women as 'occupiers' on the property of the landowner, such security does not transfer ownership of the land from the landowner to the occupiers. ${ }^{91}$ Consequently, white supremacy and male domination of the higher class, which owns the means of production pertaining to land ownership, perpetuates through democratisation, while simultaneously worsening the vulnerability of black women to land dispossession. ${ }^{92}$ Importantly, because the dichotomy of white males being the owners of land, and black women being the occupiers of such land is an effect of colonisation, the only solution to address this problem would be the decolonisation of our property law system as a whole. ${ }^{93}$

Conceptual decolonisation refers to 'the elimination from our thought of modes of conceptualisation that came to us through 
colonisation and remain in our thinking owing to inertia rather than to our own reflective choices'. ${ }^{44}$ This means the South African law of property system, including its products like ESTA, are in need of reformation in a manner that can remove the influences of racial and class inequality as well as patriarchy, as these are the effects of the colonial experience to the ownership of property. ${ }^{95}$ This can be achieved by eliminating provisions from property law legislations such as ESTA, that permit conditional and temporary occupation of black women on the landowner's property. The provisions that provide for the transfer of land ownership from the white and male landowners to black women may replace the eliminated provisions. ${ }^{96}$ This would not only alleviate the vulnerability of black women to land dispossession in this democratic era, but it would also assist in creating a strengthened self-consciousness among black women of their entitlement to equal property rights, despite being black, female and identified by society as belonging to the lower class. ${ }^{97}$

According to Oelofsen, decolonisation is defined as:

a form of transformation that colonised states undergo upon gaining political independence from their former colonisers; however, such independent states need a complete reformation because government structures, the economic structure as well as the intellect of citizens would still remain under great influence of colonisers. ${ }^{98}$

This quote helps us understand that there is an urgent need to reconstruct the entire South African property law regime, in order to remove the culture and material privilege pertaining to the ownership of land by white and male individuals, which it is currently a custodian of. ${ }^{99}$ With this said, the decolonisation of any legislation governing our country's property law should be conducted in a manner which seeks to promote a culture that transfers ownership of land to black women dominating and resist a culture of such black women being restricted to merely occupying land as farmworkers. ${ }^{100}$

The decolonisation of our country's property law system would also positively contribute towards decolonising the minds of black women from adhering to the Western cultures into being conscious and taking pride in their African origins. ${ }^{101}$ This is because the substitution of racially motivated and gender discriminatory laws,

$94 \mathrm{~K}$ Wiredu 'Conceptual decolonization as an imperative in contemporary African philosophy: some personal reflections' (2002) Rue Descartes at 56.

95 Wiredu (n 94) 58.

96 Wiredu (n 94) 59

97 As above.

98 R Oelofsen 'Decolonisation of the African mind and intellectual landscape' (2015) 16 Phronimon at 131.

99 J Modiri' The time and space of critical legal pedagogy' (2016) 3 Stellenbosch Law Review at 516.

100 Madletyana (n 25) 45 - 48.

101 T Serequeberhan "African Philosophy as the practice of resistance" (2009) 4 Journal of Philosophy: A Cross-disciplinary Inquiry at 50. 
which confine the ownership of land to white and male individuals, with reconstructed laws that promote gender and racial equality in the transfer of land ownership, would enable black women to realise that they are able to own and develop our society's means of production. ${ }^{102}$ This further promotes and protects the constitutional rights of black women to freedom of belief, religion, thought, conscience and opinion. ${ }^{103}$ Consequently, such decolonisation also assists in alleviating the vulnerability of black women to land dispossession in this democratic era through protecting their right to property, equality as well as human dignity. ${ }^{104}$

Therefore, we can analyse that the decolonisation of laws, such as ESTA which form part of our property law regime is the most suitable and appropriate remedy to address the vulnerability of black women to land dispossession in this democratic era. ${ }^{105}$ This is because the mere amendment of provisions contained in such laws will only result in the transformation of how ownership of the land is exercised by the white, male owners of the means of production, instead of actually transferring ownership rights of such land to black women. ${ }^{106}$ It is also imperative to articulate that the mere transformation of our property law system fails to address the vulnerability of black women to land dispossession because decolonisation requires a complete reformation of the entire property law system in order to achieve the end of discrimination against black women on the basis of race, gender and class. ${ }^{107}$ We can therefore argue that decolonisation is much more effective than transformation as it has the objective of totally removing any effects, influences as well as traces of colonialism that are entrenched in our property law regime, including the dispossession of land from black women. ${ }^{108}$

\section{Conclusion}

In light of this discussion, it is apparent that CRF is mainly concerned with addressing the numerous forms of oppression that manifest in the daily lives of black women due to the intersectionality of class, gender, and race. ${ }^{109}$ It is also evident that the interpretation of ESTA, in light of CRF, transforms legal knowledge to a great extent through promoting General jurisprudence as well as using the ideas underlying

102 Serequeberhan (n 101) 48-50.

$103 \mathrm{Sec} 15$ of the Constitution of the Republic of South Africa, 1996 (n 64).

104 Secs16 \& 10 of the Constitution of the Republic of South Africa, 1996 (n 64).

105 T Madlingozi 'Social justice in a time of neoapartheid constitutionalism: critiquing the anti-black economy of recognition, incorporation and distribution' (2017) 1 Stellenbosch Law Review at 129-130.

106 Madlingozi (n 105) 131-133.

107 Madlingozi (n 105) 134.

108 Madlingozi (n 105) 132-133.

109 Wing (n 22) 2-5. 
African jurisprudence, to endorse transformative constitutionalism along with a justified legal culture. ${ }^{110}$

In closing, with the intention of exposing the failures of our property law regime in this democratic era, this essay has provided an explanation of what the CRF theory entails, and also highlighted the intersectionality of class, race and gender in ESTA's failures. This essay also progressed into explaining how an interpretation of ESTA operates, as it raises an awareness among black women of their equal rights to property and their need to be adequately protected by the law from any form of unfair and unjust land dispossession, including eviction. Lastly an adequate explanation of why the decolonisation of our property law system as a whole is the most legally appropriate remedy to correct the problem of black women being the most vulnerable group to land dispossession in this democratic era has also been discussed. 


\section{SHOULD THE FLAG FIT, OR MUST WE ACQUIT?}

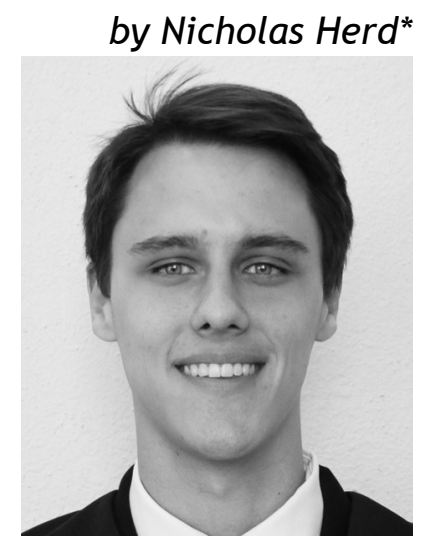

An analysis of Freedom of Expression in South Africa, with specific reference to Hate Speech and the old South African Flag.

I do not agree with what you have to say, but I'll defend to the death your right to say it. ${ }^{1}$

\section{Introduction}

Hate speech is a particular strain of expression that a society considers antithetical to its values and, through the law, seeks to curb its emission by way of regulation. As with all controversial issues within political discourse, hate speech prohibitions will either increase in scope and intensity through law reform, or recede by legislative repeal or intervention of a constitutional nature by the judiciary. ${ }^{2}$

* $\quad$ LLB III Student (University of Pretoria), Judge of the Constitutional Tribunal (2019) (University of Pretoria). I must express my appreciation of Marno Swart (a colleague on the Tribunal and dear friend) for his engagement and keen eye. I am exceedingly grateful for and indebted to Prof A. Kok (Associate Professor of Law, University of Pretoria) for his insights, patience and encouragement. I would also like to thank all of my close friends - in particular Abena Osei-Fofie and Duane van Wyk - for their support. Any impediments are attributable to me and me alone.

1 A quote attempting to capture the beliefs of the 18th century French philosopher Voltaire, and by that virtue, the Western conceptualisation of individual freedom of expression. See BE Hall The Friends of Voltaire (1906).

2 As is promised with the Prevention and Combating of Hate Crimes and Hate Speech Bill, B9-2018 http://www.justice.gov.za/legislation/hcbill/B9-2018HateCrimesBill.pdf (accessed 14 May 2019). See section 10 of the Promotion of Equality and Prevention of Unfair Discrimination Act 4 of 2000 (PEPUDA). 
When considering issues of freedom of expression from a constitutional law viewpoint at the very least, the egregious speech ought to be determined by its potential value in sparking necessary discourse, as well as its propensity to divide and harm a society still in the grip of the aftermath of apartheid. Ancillary and intimately connected to this is the question of content - where to draw the boundaries of hate speech. Which expression should we deem sufficiently egregious and harmful such that it has no place in our national and public conversation?

This paper is written in response to recent litigation before the Equality Court concerning the old South African flag. ${ }^{3}$ Following alleged gratuitous displays of the flag, the Nelson Mandela Foundation in February 2018 announced that it had made an application to the Equality Court for an order declaring the flag's gratuitous display as, inter alia, hate speech. ${ }^{4}$ The declaration sought would arguably make for a limitation on one's right to freedom of expression.

Accordingly, I assess the relief sought by the Nelson Mandela Foundation by evaluating: (1) whether conceptually hate speech prohibitions are legitimate; (2) whether section 10 of PEPUDA passes constitutional muster; and (3) whether the flag can be outright classified as hate speech under PEPUDA.

\section{A conceptual consideration of hate speech prohibitions}

\subsection{General points of departure}

It ought to be patent that hateful speech can cause harm to both intended targets and members of society alike. ${ }^{5}$ The Supreme Court of Canada, in the context of a hate speech prohibition and antiSemitic teachings, quite aptly summated the effects of hate speech

3 Reference made to 'a flag' or 'the flag' hereafter will be to the old South African flag unless indicated otherwise.

4 The application by the Foundation followed apparent displays of the flag in nationwide '\#BlackMonday' protests over attacks on farmers. The matter was set down before and heard by Deputy Judge President Phineas Mojapelo in the Equality Court on 29 and 30 April 2019. At the time of writing, Judgment remained reserved in the matter. See South African Human Rights Commission (SAHRC) 'Bid to ban old 'racist' SA flag' 26 February 2019 https://www. sahrc.org.za/index.php/sahrc-media/news/item/1780-bid-to-ban-old-racist-saflag (accessed 14 May 2019); C Ryan 'Here are the arguments for and against banning the old South African flag' 29 April 2019 https://www.groundup.org.za/ article/equality-court-asked-declare-old-sa-flag-hate-speech/ (accessed 11 May 2019); see section 10 of the PEPUDA.

5 D Milo, G Penfold \& A Stein 'Freedom of Expression' in S Woolman, T Roux, J Klaaren, A Stein, M Chaskalson \& M Bishop (eds) Constitutional Law of South Africa (2nd Edition, OS, April 2014) 15, 73. 
in observing that, the 'emotional damage' caused thereby may occasion 'grave psychological and social' harm in the form of humiliation and degradation. ${ }^{6}$ The Court remarked that the consequences of such expression bear heavily on a nation animated by values such as tolerance and dignity. ${ }^{7}$

The South African Constitutional Court in Islamic Unity Convention $v$ Independent Broadcasting Authority and Others (hereafter Islamic Unity) premised its analysis similarly, properly recognising the transformative nature of the Constitution, South Africa's history, and its commitment to 'dignity, equality, freedom, the healing of the divisions of the past and building a united South Africa'. ${ }^{8}$ The Court has gone further in keeping with a transformative and contextual approach. ${ }^{9}$ It remarked that unchecked hate speech striking at 'immutable characteristics' such as race are 'particularly harmful to the achievement of these [constitutional] values' and can 'reinforce patterns of discrimination' which has 'the potential to further divide society'. ${ }^{10}$

Hate speech further has the propensity to foster tension, division and fan the flames of violence, discrimination and other anti-social behaviour. ${ }^{11}$ Put bluntly, hate speech has the potential to compromise the vision that the Constitution of the Republic of South Africa, 1996 (hereafter the 'Constitution') sets out. ${ }^{12}$

Having entrenched the rule of law and a justiciable Bill of Rights, our Constitution sets out a vision for a transformed (continuously evolving and more) egalitarian society. ${ }^{13}$ Klare points out that our constitutional order is less liberal and more post-liberal. ${ }^{14}$ This is owing to our constitutional dispensation breaking - yet not totally from liberalism, in order to empower the state to carry out a mandate of reconstruction, revamping and remodelling (a 'transformative role and mission'). ${ }^{15}$ Klare, citing Du Plessis $v$ De Klerk, asserts that the Bill of Rights does not only impose negative restraints on the state (i.e. provide civil liberties to limit the state), but also imposes

$6 \quad R v$ Keegstra (1990) 3 SCR 697 para 227.

7 K Klare 'Legal culture and Transformative Constitutionalism' (1998) 14 South African Journal on Human Rights 146, 150.

82002 (4) SA 294 (CC) para 45.

9 Islamic Unity (n 8) para 45; Klare (n 7) 150.

10 Islamic Unity (n 8) para 45.

11 Milo et al (n 5) 76; Islamic Unity (n 8) paras 33, 45.

12 Islamic Unity (n 8) paras 33, 45.

13 Klare (n 7) 151, 156, 171; D Moseneke 'The fourth Bram Fischer memorial lecture - transformative adjudication' (2002) 18 South African Journal on Human Rights 309, 316.

14 Klare (n 7) 152. It appears that Klare is referring to the notion or principle that freedom, as a default, ranks above state interventionism or interference.

15 Klare (n 7) 153, 155 
affirmative duties on government to, inter alia, promote social welfare and assist people in enjoying their constitutional rights. ${ }^{16}$ Any state ought rightfully to be concerned with, and at least have a legitimate interest in, curtailing hate speech in the name of dignity and equality. ${ }^{17}$ None more so than South Africa, having relatively recently transitioned from a long history of institutionalised racism and inequality. ${ }^{18}$ As aforementioned, the state appears to bear a special responsibility in ameliorating harm and securing rights.

However, in recognising what the flag meant as a symbol and what it still means to those who were subjugated under its colours, one must also resist the 'knee-jerk' reaction to 'transform' and 'redress' the situation by quick panacea or through wholesale prohibition. It is important to recognise that long-term goals can be compromised by immediate or inter-mediate solutions intended to rectify historical injustice. This is why the courts, when reviewing such measures, are enjoined to enquire whether any such initiative will further the constitutional vision in the long term. ${ }^{19}$

As pointed out by Meyerson, censorship laws can easily mutate through different application or over time; the intention in drafting might be to address one character of expression, but the law can be deployed alternatively to prohibit other types of expression proven to be expedient for the government of the day. ${ }^{20}$ The obvious danger is, whilst we might accept a 'neutral' law for its good intentions in the moment, that same law might later be wielded as a weapon against what we hold dear. It is precisely because hate speech exists in such an emotionally charged orbit that it is likely to be regulated with a heavy and overly broad hand. ${ }^{21}$ This, in-and-of itself, is cause for concern in a constitutional and rights driven democracy such as South Africa. There are two primary reasons for said concern: the value of (largely) uninhibited expression in general; and more specifically, the need for a young democracy to come to terms with its new identity organically, while it is gripped in the 'teething' process of transition out of a particularly painful past (with very real vestiges still remaining). Both concerns are amplified by the protection that section 16 of the Constitution affords almost all species of expression - except for its specifically enumerated exceptions. ${ }^{22}$ As stated above, the Nelson Mandela Foundation has asked of the Equality Court

16 Du Plessis v De Klerk 1996 (5) BCLR 658 (CC) para 147. Klare (n 7) 154. Klare also references the Preamble as well as secs 1(a), 7(2) \& 39(1) of the Constitution.

17 Islamic Unity (n 8) para 33.

18 Milo et al (n 5) 73.

19 Minister of Finance and Other $v$ Van Heerden 2004 (6) SA 121 (CC) para 44. This is when considering matters of discrimination and measures purporting to be the implementation of substantive equality or redress.

20 D Meyerson "“No platform for racists": what should the view of those on the Left be?' (1990) 6 South African Journal on Human Rights 394, 397.

21 Milo et al (n 5) 73.

22 Sec $16(2)$ of the Constitution. 
to exercise its powers under section 21 of PEPUDA and place an almost outright ban on the display of the apartheid flag: a near blanket ban. ${ }^{23}$

\subsection{The inherent value of speech}

Although it has expressly disavowed the US Supreme Court's jurisprudence of First Amendment (freedom of speech) 'preeminence', the Constitutional Court has recognised the fundamental importance of the right to freedom of expression, characterising it as the 'lifeblood of an open and democratic society cherished by our Constitution' and a prime freedom 'upon which all the other freedoms depend'.24 The protection of the right to expression is widely considered intimately connected to the ideals fundamental to a constitutional and rights driven democracy.

A motivation for the entrenchment of a general right to freedom of expression is the promotion of autonomy and dignity: that everyone is rational and of equal worth, that no person should be told that their views are less valuable and should therefore not be expressed. ${ }^{25}$

Traditionally, the 'search for truth' and 'the marketplace of ideas' theories have been propositioned as champions for contesting historical and contemporary restrictions on the 'free trade' in information. 26 The logic is that a decrease in the restriction on information disseminated increases the rate of collision of different strings of information, thereby increasing the likelihood of lingering falsity being cancelled out and the truths contained in the different pieces of information being revealed and established. ${ }^{27}$ Milo, Penfold and Stein astutely conclude that these theories are especially compelling when some objectively ascertainable fact is at issue and its veracity might result in some good being achieved. ${ }^{28}$ They further note that the rationales apply equally to the contents of 'opinion', as one opinion might be more correct than another and might, by its utterance, persuade others to accept it. ${ }^{29}$ Schauer asserts that the purpose is not solely the attainment of objective truth but of 'epistemic advancement' in general. ${ }^{30}$ A case can be made for

23 SAHRC https://www.sahrc.org.za/index.php/sahrc-media/news/item/1780-bidto-ban-old-racist-sa-flag (n 4); Ryan (n5) https://www.groundup.org.za/article/ equality-court-asked-declare-old-sa-flag-hate-speech/.

24 S v Mamabolo (E TV and Others intervening) 2001 (3) SA 409 (CC) paras 40, 41; Dikoko v Mokhatla 2006 (6) SA 235 (CC) para 92; Mandela v Falati 1995 (1) SA 251 (W) para 259.

25 Milo et al (n 5) 14.

26 The justification is widely considered attributable to John Milton's articulation, dating to around 1644. See Abrams v US $250616,628,40$ SCt 17 (1919) para 637.

27 J Mils \& E Rapaport On liberty (1978) 16, 19.

28 Milo et al (n 5) 18.

29 As above.

30 As above; FF Schauer Free speech: a philosophical enquiry (1982) 18. 
opening up this 'market place' to ensure greater access for those who are impoverished or disfavoured, as opposed to further restricting it. 31

In their assessment, because government is poorly placed to do so, Milo, Penfold and Stein properly caution against government regulation of the exchange of information, except in the most considered and necessary of circumstances. ${ }^{32}$ They argue that government invariably has a stake in the information being exchanged because the information would often (or at least might) be about it or its political interests, i.e. maintaining or changing the status quo. ${ }^{33}$

Another more prominent case for speech protection is the proper functioning of democracy: that freedom of expression is the vector for the realisation of the 'twin values' of accountability and participation. ${ }^{34}$ O'Reagan $\mathrm{J}$ insightfully posited in Khumalo and Others $v$ Holomisa (hereafter Khumalo): 'without [freedom of expression], the ability of citizens to make responsible political decisions and to participate in public life would be stifled'. ${ }^{35}$ The Constitutional Court has recognised the interplay between access to information and the right to vote in no less than two landmark rulings: Democratic Alliance $v$ African National Congress and Another (hereafter ANC $\vee$ DA), and My Vote Counts NPC $v$ Minister of Justice and Correctional Services and Another (hereafter My Vote Counts). ${ }^{36}$ The premise of this argument is not that freedom of expression flows from the democratic model, but that it is a necessary precondition for it to operate effectively. ${ }^{37}$

Self-fulfilment bolsters the need to protectively ring-fence freedom of expression because it allows for the 'free development of an individual's intellect, interests, tastes and personality'. ${ }^{38}$ Van der Westhuizen $\mathrm{J}$ aptly captured the proposition in stating:

[E]xpression is an essential part of one's awareness of oneself, one's very being, and one's human dignity. There is thus an element of the

31 Milo et al (n 5) 19, 20.

32 Milo et al (n 5) 21.

33 As above.

34 Milo et al (n 5) 23.

352002 (5) SA 401 (CC) para 21; Milo et al (n 5) 24.

36 Democratic Alliance v African National Congress and Another 2015 (2) SA 232 (CC). The Court emphasised the interconnectivity between the right to freedom of expression, and that suppressing speech in an election period would inhibit valuable speech necessary to promote open and vigorous debate on public affairs primarily needed to inform the electorate and help them form their opinions. My Vote Counts NPC v Minister of Justice and Correctional Services and Another 2018 (5) SA 380 (CC).

37 Milo et al (n 5) 24.

38 Gardener $v$ Whitaker 1995 (2) SA 672 (E); see also Case and Another $v$ Minister of Safety and Security and Others; Curtis v Minister of Safety and Security and Others 1996 (3) SA 617 (CC) para 26 (Mokgoro J: freedom of expression 'is foundational to each individual's empowerment to autonomous selfdevelopment'); Milo et al (n 5) 25. 
protection of dignity involved in the protection of expression. Therefore not only true or meaningful statements, which could contribute to a debate, are protected, but also other forms of expression, simply because it is human to communicate. ${ }^{39}$

Moreover, as much as it is a human necessity for the iterator to express, it is equally important for the receiver to discern and be exposed to varying types, qualities and contents of information only receivable when speech can flow freely. ${ }^{40}$ It speaks to the development of one's identity through an appreciation and evaluation of the content.

\subsection{Free speech as a necessary ingredient in South Africa's transition}

A question of tolerance arises: Would more (especially controversial) speech result in greater tolerance? The Constitutional Court has answered this inquiry by identifying tolerance as a mere 'acceptance of the airing of disagreements' - not necessarily the 'approbation of' a point's substance - by 'refusing to silence unpopular [or offensive?] views'. ${ }^{41}$ The Court in Minister of Home Affairs v Fourie (Doctors for Life International and Others, Amici Curiae); Lesbian and Gay Equality Project and Others $v$ Minister of Home Affairs (hereafter Fourie) pronounced that, where difference in diversity is concerned, the Constitution, specifically the right to equality, rejects the 'suppression of difference' and requires an 'acknowledgment and acceptance of difference' that 'celebrates the diversity of the nation'. 42 The Court crucially stated that the test for tolerance is how one 'accommodates the expression of what is discomforting'. 43

Klare is correct in referring to the Postamble of the Interim Constitution in his motivation for our constitutional order to continue being that 'historic bridge'. ${ }^{44}$ Our young democracy is still in flux, still finding its feet. For this reason, freedom of expression is all-the-more important as it forces people to confront differences in points of view and develop a common understanding. ${ }^{45}$ This is even where disagreement on the substance exists. Of course, as observed above, it might be necessary to ban certain categories of speech that are

39 Holomisa v Khumalo 2002 (3) SA 38 (T) para 61; Milo et al (n 5) 26.

40 Milo et al (n 5) 26, 27.

41 South African National Defence Union v Minister of Defence and Another 1999 (4) SA 469 (CC) (hereafter SANDU v Minister of Defence) para 8; Milo et al (n 5) 28.

422006 (1) SA 524 (CC) para 60; Milo et al (n 5) 29.

43 Fourie (n 42) para 60; Milo et al (n 5) 29.

44 Klare (n 7) 155; Postamble of the Constitution of the Republic of South Africa Act 200 of 1993.

45 V Blasi 'Free Speech and good character' in L Bollinger \& G Stone (eds) Eternally vigilant: Free speech in the modern era (2002) 46, 84. 
inherently repugnant to, for example, our grand project of national reconciliation. 46

Withstanding the above, it must be noted that critics argue that, beyond the lack of empirical evidence to prove that hate speech bans achieve their ends, they may, as a matter of fact, be self-defeating. ${ }^{47}$ Enforcement of a prohibition brings greater attention to the cause of the offender through publicity. ${ }^{48}$ This carries the possibility of martyring them. ${ }^{49}$ Klare's work emphasises that the Constitution's blueprint is a fundamentally broad conceptualisation of society that, by design, is meant to be timeless and must continue revising the status quo. ${ }^{50}$ It should be clear then that (mostly) unbridled expression is one of the best devices for challenging the status quo. However, on this score, and as noted above, the law often becomes a weapon for silencing those disaffected and vulnerable classes of society who speak out against the status quo and who criticise the government, as was the case under apartheid. ${ }^{51}$ This 'self-defeating' thesis also extends a word of warning, that suppression must be undertaken with careful consideration. This is because 'to drive evil underground can actually increase its strength'. ${ }^{52}$ This is instead of allowing it to either 'bleed off' through a safety valve of freedom of expression, or confronting it in the open. ${ }^{53}$ Open confrontation made more probable by expressive freedoms is likely to reveal the repugnant nature of evil speech. ${ }^{54}$ Restriction and suppression on the other hand might actually cause bigotry to fester into violent eruption. ${ }^{55}$

One must consider that the expression of views, ideas, ideology or information in general falls on a spectrum, i.e. in the margins as much as it does in grey areas. First, it is often questionable whether a particular statement actually constitutes hate speech (and this answer will also depend on what the test for hate speech is at the particular time). It might be that a statement before a court is misclassified. It might be that a massive and important 'cold-war' discourse, raging as an undercurrent in society, fails to surface into

Klare (n 7) 155.

As above.

This has been seen recently in reporting of persons such as Penny Sparrow and Velaphi Khumalo: the media replicates and distributes the very incendiary content the law seeks to quash.

Milo et al (n 5) 77, 78. See Keegstra (n 6) para 304.

Klare (n 7) 155.

Milo et al ( $\mathrm{n}$ 5) 78. L Johannessen 'A Critical View of the Constitutional Hate Speech Provision' (1997) 13 South African Journal on Human Rights 135, 136. Meyerson (n 20) 397; Milo et al (n 5) 78.

Milo et al (n 5) 29.

Meyerson (n 20) 397.

As above; Milo et al (n 5) 78. 
the public arena because nobody speaks up for fear of being reported or prosecuted, or because of a recent court ruling on the subject. 56 The implication is that society then cannot grapple with systemic and institutional problems such as silent 'dog-whistle' racism or antiSemitism. ${ }^{57}$

In the instance that the expression itself carries no substantive value, nonetheless, the debate that flows from its dissemination might. It seems that there is value in discovering what hateful people think and why, so that, inter alia, misconceptions can be confronted and unacceptable ideologies combatted. The only way to undertake such investigation is - aside from probing brains - to cultivate an environment conducive to robust and expressive dialogue and having society speak up. The trade-off then is obviously allowing people to purchase and spend airtime in our various spaces of discourse, to the offense, or even hurt, of some or many.

The Constitutional Court in S v Mamabolo had the following to say about the right to freedom of expression and it bears even greater importance during this period which one can classify as 'the emergence from oppression':

Freedom of expression, especially when gauged in conjunction with its accompanying fundamental freedoms, is of the utmost importance in the kind of open and democratic society the Constitution has set as our aspirational norm. Having regard to our recent past of thought control, censorship and enforced conformity to governmental theories, freedom of expression - the free and open exchange of ideas - is no less important than it is in the United States of America. It could actually be contented with much force that the public interest in the open marketplace of ideas is all the more important to us in this country because our democracy is not yet firmly established and must feel its way. Therefore we should be particularly astute to outlaw any form of thought control, however respectably dressed. ${ }^{58}$ (emphasis added)

The Court implies that, in some part at least, progress in society will need to occur organically as the South African society finds its own truth and identity through collision with error. Such collision and

56 S Teichner 'The hate speech provisions of the Promotion of Equality and Unfair Discrimination Act 4 of 2000: the good, the bad and the ugly' (2003) 19 South African Journal on Human Rights 349, 366.

57 A 'dog whistle' is a political term for statements that appear innocent to the general public but they actually use subtle, coded language to communicate a secondary message to an intended group. Dictionary.com 'Dog whistle' https:// www.dictionary.com/e/politics/dog-whistle/ (accessed 6 August 2019). This raises the issue that implicitly racist and bigoted people often find ways of using in coded language to communicate with, for example, their supporters and political base. Lowering the threshold for a general test to target the innuendo and connotation that is situated within coded speech risks targeting important and legitimate speech that contains no such innuendo. It might possibly even chill whistle blowing or calling out and criticism of the use of the coded language in the course of robust debate. See Teichner (n 56) 366.

58 Mamabolo (n 24) paras 40, 41. 
identity mapping, as set out above, can only occur where the error is permitted to rear its head. Tolerance is of immense importance, especially when considering the need for South Africa to 'feel its way' through discourse, even if that discourse is uncomfortable.

The appeal committee of the Human Rights Commission in Freedom Front $v$ South African Human Rights Commission (hereafter Freedom Front) noted the danger of interpreting section 16(2)(c) widely in observing that:

[S]peech that is vitally important to the advancement of our constitutional democracy may be classified as hate speech, because our society is still in respect of significant social issues, divided on racial [and other fault-] lines. Any test suggested for interpreting section $16(2)$ (c) must recognise that the section is an exception and that the protection of the freedom of expression is the norm. ${ }^{59}$

\subsection{Preliminary conclusion: Proceed with caution}

In summary then, it is clear that hate speech has the capacity to cause harm, and further lacks value - indeed, racism and the like have no merit - except for the value that can be ascribed to all expression in general (its 'inherent value'). ${ }^{60}$ This inherent value might be situated in the expression's premises or its margins, or in the debate that flows from its dissemination. Patently, much 'hate speech' will be valueless in content, but that is all the more reason why it is crucial to properly calibrate the law to surgically strike only at expression that is unprotected or can be justifiably limited. It is obvious that the state has a role to play in regulating such speech. The question is how?

\section{Section 16 of the Constitution: The right to freedom of expression}

\subsection{The South African approach to freedom of expression}

Section 16 of the Constitution entrenches the right to freedom of expression. It is structured in two parts. ${ }^{61}$ Section $16(1)$ provides both a general right to freedom of expression that goes beyond its listed components, as well as a list of specifically protected forms of expression; and section 16(2) carves out certain categories of

59200311 BCLR 1283, 1297; Milo et al (n 5) 84.

60 Meyerson (n 20) 397. I most certainly align myself with this position.

61 Sec 16 of the Constitution provides that -

Everyone has the right to freedom of expression, which includes -

freedom of the press and other media;

freedom to receive or impart information or ideas;

freedom of artistic creativity; and

academic freedom and freedom of scientific research. 
expression from the constitutional protection afforded by section $16(1) .^{62}$

Section 16's scheme demands a default setting of protection for any expression that falls within its ambit. This is aptly explained by the Court in De Reuck $v$ Director of Public Prosecutions (Witwatersrand Local Division) and Others (hereafter De Reuck) where it held that even content with 'little value', in casu child pornography, fell under section 16(1)'s protection because it was not and is not a form of expression excluded by section 16(2). ${ }^{63}$

Section 16(1) protects all forms of freedom of expression not specifically excluded by section $16(2) .{ }^{64}$ Where expression falls within subsection (2), it does not enjoy the protection of the constitutional right to freedom of expression. If the expression falls within section $16(2)$, no constitutional right is impacted because it is as if, for the purposes of that expression, the right does not exist. What follows is that expression envisaged by section 16(2) is always trumped by a limiting law because it has no constitutional protection to raise as a shield. ${ }^{65}$

It is of importance to note that section 16(2) does not prohibit any form of expression itself. ${ }^{66}$ It only removes constitutional protection from the species of expression it enumerates. ${ }^{67}$ This means that any limitation of any expression that is not contemplated by section 16(2) must satisfy section 36(1) limitation - because it is automatically afforded the protection of the right. ${ }^{68}$

Even within the parameters of section 16(1), freedom of expression is not an absolute right, but can be limited by a law of general application in terms of section $36(1) .{ }^{69}$ It is also not a 'paramount value'. 70 Our courts have expressly disavowed the US

The right in subsection (1) does not extend to -

propaganda for war;

incitement of imminent violence; or

advocacy of hatred that is based on race, ethnicity, gender or religion, and that constitutes incitement to cause harm.

62 Islamic Unity (n 8) paras 31-33.

632004 (1) SA 406 (CC) para 61.

64 Milo et al (n 5) 11.

65 As above.

66 Islamic Unity (n 8) para 32; 'Supreme Court of Appeal gets the law very wrong in a Hate Speech judgment' $P$ de Vos 6 December 2018 https://constitutionallys peaking.co.za/supreme-court-of-appeal-gets-the-law-very-wrong-in-a-hate-spee ch-judgment/ (accessed 18 May 2019) (De Vos 2018); 'Qwelane: Still a homophobe, but his challenge to hate speech clause is sound' $P$ de Vos 3 September 2013 https://constitutionallyspeaking.co.za/qwelane-still-a-homo phobe-but-his-challenge-to-hate-speech-clause-is-sound/ (accessed 18 May 2019) (De Vos 2013).

67 Islamic Unity (n 8) paras 31-33.

68 Milo et al (n 5) 6; Islamic Unity (n 8) paras 31-33.

69 Phillips V DPP, Witwatersrand Local Division 2003 (3) SA 345 (CC) (hereafter Philips) para 17.

70 Khumalo (n 35) para 25. 
Supreme Court's jurisprudence of the First Amendment (freedom of speech) 'pre-eminence'. ${ }^{71}$ Instead, the Courts have opted for a balancing of rights based on the facts of each case when determining the validity of a limitation or contest between two competing rights. ${ }^{72}$ This means that the freedom of expression, as important as it is, does not automatically 'trump' a right such as human dignity. ${ }^{73}$

The courts have broadly interpreted 'expression' as contained in section 16 as including 'any material that communicates or attempts to communicate meaning'. ${ }^{74}$ This would obviously include any attempt to communicate verbally, to publish, to write and to display content or information. The right to freedom of expression supplied by section 16 extends to and protects even offensive, shocking, and disturbing content. ${ }^{75}$ As it should for the conceptual reasons laid out above. $^{76}$

\subsection{The exclusions: Section 16(2)}

The pivotal inquiry therefore is whether the mere display of the flag amounts to 'advocacy of hatred that is based on race, ethnicity, gender or religion, and that constitutes incitement to cause harm'. ${ }^{\prime}$ If it does amount to such expression, then the enquiry and indeed this article would end here. The flag would not be protected by the right to freedom of expression. Legislation, namely PEPUDA, would be able to prohibit it (by classifying it as hate speech) without any need for section 36(1) justification. There would be no grounds for the balancing of rights and no attendant discussion. If it does not constitute excluded expression, then PEPUDA's prohibition will constitute an infringement of the right because the display will be protected under section 16(1).

Section 16(2) enumerates three types of expression that are ousted from constitutional protection. ${ }^{78}$ The list includes propaganda for war and expression amounting to advocacy of hatred that incites harm. The exclusion with the lowest threshold relevant to PEPUDA's section 10 hate speech prohibition, as well as the display of the 'old South African flag', is section 16(2)(c), which in two elements, allows for the limitation of 'egregious hate speech'. 79

71 Mamabolo (n 24) paras 40, 41

72 Mamabolo (n 24) paras 41.

73 As above.

74 Milo et al (n 5) 10; De Reuck (n 62) para 48.

75 Islamic Unity (n 8) para 28; De Reuck (n 62) para 49.

76 See paragraph 2.2 and 2.3 of this article.

77 Sec $16(2)$ of the Constitution.

78 As above.

79 Milo et al (n 5) 11. 
For expression to amount to 'egregious hate speech' as contemplated by section 16(2)(c), it must: (i) amount to advocacy; (ii) qualify as hatred; (iii) be based on race, ethnicity, gender or religion; (iv) constitute incitement; and (v) be directed to causing harm. If not, the requirement of section $36(1)$ justification is triggered to serve as the limitation.

Section $16(2)(c)$ sets a compounded and high threshold. ${ }^{80}$ The advocacy of hatred (a high internal threshold) will, by itself, be insufficient to trigger the ousting of the right to freedom of expression. ${ }^{81}$ The contentious issues are dealt with in turn below.

\section{(i)}

\section{'Advocacy'}

'Advocacy' implies the active promotion of a cause. ${ }^{82}$ Currie and de Waal classify advocacy as, to 'call for or make a case for' the cause. ${ }^{83}$ 'Advocate' is a strong verb. ${ }^{84}$ It has been described as 'exhortation, pleading for, supporting or coercion'. ${ }^{55}$ The Canadian Supreme Court in $R \vee$ Keegstra described 'advocacy' in the following language, stating:

['Promotes hatred'] indicates active support or instigation ... [it] indicates more than simple encouragement or advancement. The hatemonger must intend or foresee as substantially certain a direct and active stimulation of hatred against an identifiable group. ${ }^{86}$

Klare admits that, whilst exegesis must be through a transformative matrix, the law is not infinitely plastic. ${ }^{87}$ It is difficult to conceive how displaying the flag in isolation can constitute active conduct that is, anything more than passive encouragement or support - let alone exhortation or coercion. Furthermore, the terms 'advocacy', 'hatred' and 'incitement', individually but more so cumulatively, indicate that the constitution requires subjective intention on the part of the person making the expression. ${ }^{88}$ At most, displaying the flag could (discretely) be considered passive yet open or public support for the apartheid regime or any of its aspects; or it could be a component of some larger scheme of conduct which might, cumulatively, constitute advocacy. However, in-and-of itself, the flag, even as a powerful symbol, does not meet the high threshold.

80 Milo et al (n 5) 79.

81 As above.

82 Milo et al (n 5) 80.

83 I Currie \& J de Waal The Bill of Rights Handbook (2005) (5th ed) 375.

84 J Botha \& A Govindjee 'Hate speech provisions and provisos: a response to Marais and Pretorius and proposals for reform' (2017) 20 Potchefstroom Electronic Law Journal/Potchefstroomse Elektroniese Regsblad 1, 13.

85 C van Wyk 'The Constitutional treatment of Hate Speech in South Africa' (2003) 18 SA Publiekreg /SA Public Law 182185.

86 Keegstra (n 6) para 120.

87 Klare (n 7) 149.

88 Milo et al (n 5) 83. Teichner (n 56) 380. 
There are two contexts which are important here. First is the historical context of racial injustice that the symbol of the flag might propound in consequence. Its symbolism must inflict a profound hurt that has been imposed on the majority of the South African population for centuries. However, this context must be considered in light of section 16(2)(c) which requires a certain quality and intensity of the content. The standard is not 'to merely offend or upset' (which, as noted above, is protected); a higher threshold of 'hatred' is set. This is clear from the holding in $R \vee$ Andrews, where the Canadian Supreme Court stated that hatred cannot be 'casual' (possibly, to also mean inadvertent, unintentional or normal), but it connotes the 'instilling of malevolence'. ${ }^{89}$

Modiri contributes to the definition of 'white supremacy' (which a transformative constitution obviously turns its back on) by, in part, stating that it includes:

... (3) relations and images of white dominance and Black subordination [that] are re-enacted daily across a wide array of institutions, spaces, platforms, media and social settings - both private and public, intersubjective and structural. ${ }^{90}$

The flag might well be such a re-enactment in certain contexts. As contextualised above, hatred is an extreme emotional standard. The flag has a range of calibrations, which are set according to context (in terms of conduct or words). In some contexts, the flag might be an element in an artistic or journalistic creation; in others, it might be a rallying cry. Flying the flag coupled with some other qualifying conduct would probably add up to hatred. If displaying the flag was intended to romanticise and reminisce on the days of apartheid, it could rise to the standard of spreading hatred owing to its status as a symbol of deep division and dehumanisation when taken in the context of apartheid.

Withstanding the above, 'hatred' seems to imply an element of subjective intention; that the emotion wrought behind the content must be directed and purposeful, or at least conscious. This conclusion aligns with some of the commentators who analysed the elements of 'advocacy' and 'hatred' conjunctively. ${ }^{91}$ The purpose of the advocacy is to spread the hatred. The hatred serves to demonise and invite harm upon the targeted group or its members. If subjective intention is an internal element of 'hatred', then an objective

$89 R \vee$ Andrews (1990) 3 SCR. 870 para 211.

$90 \mathrm{~J}$ Modiri 'The "Event" of racism' 17 November 2016 https://www.daily maverick.co.za/opinionista/2016-11-17-the-event-of-racism/\#.WJI4BvKf1Hw (accessed 14 May 2019).

91 Milo et al (n 5) 80; Teichner (n 56) 380. 
inference in-and-of itself will be insufficient to discharge the burden of proving 'hatefulness' in respect of flying the flag.

Section $16(2)$ (c) requires 'advocacy of hatred' as a means to a specific end, namely, causing harm. As aforementioned, hate speech has the potential to do 'emotional damage' thereby, occasioning 'grave psychological and social' harm in the form of humiliation and degradation. 92

It is accepted that 'harm' is not limited to the realm of the physical but extends to psychological and other forms of harm that can be perpetrated. However, as the appeal committee of the South African Human Rights Committee held, the harm must be significant and surpass mere offence. ${ }^{93}$ The harm must be something material coupled with another injury such as violence, harassment or verbal abuse. ${ }^{94}$

The Constitutional turning point, however, is indirect causation. It is not whether the speech itself did the harming but whether it would incite others to cause harm. ${ }^{95}$ Again, as with 'advocacy', incitement requires that the utterer act towards the objective of generating some material outcome by way of their expression. As Milo, Penfold and Stein explain, the harm must flow from the hate speech. ${ }^{96}$ They correctly argue that the speech must 'amount to advocacy of hatred and [as well as] incitement to cause harm', and that hatred or advocacy of hatred, without incitement to cause harm, is insufficient to trigger section $16(2)(c) .{ }^{97}$

Section 16(2)(c) encompasses, for example, an inflammatory speech at a local meeting calling for the lynching of black neighbours, or the propositioning at that meeting to phone and harass black neighbors with the object of driving them out of town. ${ }^{98}$ It does not seem as though the old flag can do any of this by itself, unless it is a pre-arranged signal for a pact to be implemented. But even then, any flag could be a pre-determined and specified indicator - the current South African flag could even be used for such a purpose.

92 Keegstra (n 6) para 227.

93 Freedom Front (n 59) 1295.

94 Milo et al (n 5) 83.

95 As above.

96 Milo et al (n 5) 79.

97 As above.

98 As above. 


\subsection{Constitutional status of the flag}

It is therefore clear that the flag, whilst understandably hurtful and hateful to many, cannot fall into the exclusions. It thus finds its way into the penumbra of section 16(1) and therefore constitutes protected expression by default. The question is then whether the protected right can be limited in the way that section 10 of PEPUDA does.

\section{Constitutionality of section 10 of PEPUDA}

\subsection{Inconsistency with Section 16(2)}

As set out above, the Constitution carves out 'hate speech' from its protection as a species of expression and in doing so establishes a high threshold. Section 10 of PEPUDA lowers that watermark substantially and implicates - and thereby civilly limits - speech on a far more drastic basis. ${ }^{99}$

There are several discrepancies between section $16(2)(\mathrm{c})$ and section 10 of PEPUDA. For example, section 16(2)(c) of the Constitution only requires that the speech in question incite some sort of harm (that the harm is one step removed from the speech). However, section 10 of PEPUDA ensnares speech which does the harming or hurting itself. ${ }^{100}$ Section 10 also increases the number of grounds from the four listed in section 16(2)(c), on which hate speech can be perpetrated, to sixteen. ${ }^{101}$

Both inconsistencies are arguably permissible and justifiable limitations of the right to freedom of expression. First, the additional grounds merely bring the list at section 16 more closely in line with section $9(3)$ of the Constitution. ${ }^{102}$ Second, tackling direct (as opposed to only indirect) adverse consequences of incendiary speech is consonant with our constitutional jurisprudence which recognises the state's interest in preventing all or any harm, and that harm can flow directly from hateful speech. ${ }^{103}$

99 Milo et al (n 5) 86; See secs 21 of PEPUDA for a list of the powers and functions of the Equality Court which may be invoked in matters of hate speech; the list appears to include prohibition. See de Vos 2013 (n 67) https://constitutionally speaking.co.za/qwelane-still-a-homophobe-but-his-challenge-to-hate-speechclause-is-sound $/$.

100 Milo et al (n 5) 88.

101 See sec 1 of PEPUDA ('Prohibited grounds').

102 L Botha \& A Kok 'How to make sense of the civil prohibition of Hate Speech in terms of the Promotion of Equality and Prevention of Unfair Discrimination Act 4 of 2000' to be published in Southern Africa Public Law (draft on file with author) 20.

103 Islamic Unity (n 8) paras 33 \& 45. 
The two main problems with section 10 are the lowering of thresholds, and the imposition of an objective, reasonable person test that ignores subjective intention.

\section{(i)}

\section{Hurtfulness}

The threshold of section 10 is lowered by employment of the standard of 'hurtful[ness]'. Section 10 of PEPUDA stipulates that a person may not 'publish, propagate, advocate or communicate words' that 'could reasonably be construed to demonstrate a clear intention to be hurtful; harmful or incite harm; or promote or propagate hatred'.

'Harmful' and 'hatred' are textually consistent with section $16(2)$ (c) and so there is likely no constitutional challenge to be made on that score. However, the word 'hurtful' (read with 'harmful') casts a much broader net. ${ }^{104}$ This is especially true when interpreted against the reasonable person standard. ${ }^{105}$ The hate speech prohibition could then target an inordinate portion of discourse which society actually considers acceptable, if not beneficial, ranging from insensitive jokes made privately to robust opinions on racial issues. ${ }^{106}$ De Vos illustrates this point well by arguing that any genuine view on a specific issue that implicates a listed ground can likely be taken, objectively, as offensive and hurtful. ${ }^{107} \mathrm{He}$ asserts that this would include religious teachings on subjects such as homosexuality, with the unacceptable result of such religious expressions being prohibited or sanctioned. 108

Several examples highlighted by De Vos are religious in nature. In the most extreme exercise of the Equality Court's powers, the banning of the communication of religious teachings will strike at rights such as one's section 15 right to freedom of religion, thought, conscience and belief, as well as the right to form cultural and religious communities (section 31 of the Constitution). Religious and

104 De Vos 2013 (n 66) https://constitutionallyspeaking.co.za/qwelane-still-ahomophobe-but-his-challenge-to-hate-speech-clause-is-sound/; Milo et al (n 6) 87.

$105 \mathrm{~J}$ Modiri 'Race, realism and critique: the politics of race and Afriforum $v$ Malema in the (in)equality court' (2013) 130 The South African Law Journal 274; De Vos 2013 (n 66) https://constitutionallyspeaking.co.za/qwelane-still-a-homophobebut-his-challenge-to-hate-speech-clause-is-sound/.

106 Milo et al (n 5) 87.

107 De Vos 2013 (n 66) https://constitutionallyspeaking.co.za/qwelane-still-ahomophobe-but-his-challenge-to-hate-speech-clause-is-sound/ ("Much of the teaching of mainstream religious groups on homosexuality, for example, would almost certainly fall foul of the hate speech provision. When a priest or imam targets "practicing" gay men and lesbians (as if we need any practice) in a talk and brands us as "sinners", many so called reasonable people will surely assume that they had the intention to be hurtful to gay men and lesbians ... But should such speech be banned? I am far from certain that it should').

$108 \mathrm{Or}$ at least deterred by apprehension or by the sanctions imposed by the court. See De Vos 2013 (n 66) https://constitutionallyspeaking.co.za/qwelane-still-ahomophobe-but-his-challenge-to-hate-speech-clause-is-sound/. 
cultural groups would be inhibited from imparting doctrines, cultural understandings and teaching practices. Such abilities form the foundation of these associations and aspects of life. ${ }^{109}$

Milo, Penfold and Stein suggest an interpretative prophylactic: that 'harm' can be interpreted narrowly to only physical harm or violence; and 'hurtful' restrictively to extend to only serious and material consequences, in line with the constitutional standard analysed above. 10

Botha and Kok take up the gauntlet in opposition to this, countering that the impugned standard of 'hurtfulness' was in fact vindicated (in delictual terms) by the Constitutional Court in Le Roux and Others $v$ Dey (hereafter Le Roux $v$ Dey) - read with its holding in The Citizen 1978 (Pty) Ltd v Mcbride (hereafter Citizen v Mcbride). ${ }^{111}$ They effectively argue that the holdings in these cases render the standard a constitutionally permissible ingredient in any the limitation of freedom of expression. ${ }^{112}$ They submit that because the standard is good in delict, it is good in PEPUDA. ${ }^{113}$

I am not certain that I can countenance this proposition. First, fault in the form of actual (subjective) intention is not a requirement under PEPUDA. ${ }^{114}$ It is a requirement in defamation and impairment of dignity actions which were considered by the Court in Le Roux $v$ Dey. ${ }^{115}$ Second, in defamation or impairment of dignity claims, actual hurt or harm must be effected. ${ }^{116}$ Under PEPUDA, the requirements of both causation and injury are absent. There is no requirement that harm (or hurt) actually be caused; only that the intention to do so be objectively determinable. ${ }^{117}$ These added elements in delict appear to differentiate delictual claims from those under PEPUDA.

109 S Woolman 'On the fragility of associational life: A constitutive liberal's response to Patrick Lenta' in S Woolman and D Bilchitz Is This Seat Taken? Conversations at the Bar, the Bench and the Academy about the South African Constitution (2012) 118, 119.

110 Milo et al (n 5) 87. See paragraph 3.2 of this article.

1112011 (3) SA 274 (CC) para 119; 2011 (4) SA 191 (CC) para 79; Botha \& Kok (n 102) 25.

112 Botha \& Kok (n 102) 25; Le Roux v Dey (n 111) para 119; Citizen v Mcbride (n 111) para 79.

113 Botha \& Kok (n 102) 27, 28

114 Botha \& Govindjee (n 84) 14; Botha \& Kok (n 102) 21, 23 \& 24; De Vos 2013 (n 66) https://constitutionallyspeaking.co.za/qwelane-still-a-homophobe-but-hischallenge-to-hate-speech-clause-is-sound/.

115 Le Roux $v$ Dey (n 111) paras 84 \& 129-134.

116 In the form of defamatory effect or injury to dignity. Le Roux $v$ Dey (n 111) paras $84,92,118,145$.

117 Teichner (n 56) 354; De Vos 2013 (n 66) https://constitutionallyspeaking.co.za/ qwelane-still-a-homophobe-but-his-challenge-to-hate-speech-clause-is-sound/. 
Thirdly, the Court in Le Roux $v$ Dey might have approved of the 'hurtfulness' standard in the context of delict, however, as noted, the Court has twice over affirmed that offensive, shocking and disturbing content is protected. ${ }^{118}$ One of those cases is the only hate speech case that has reached the Constitutional Court. ${ }^{119}$ As far as the two precedents (arising out of different contexts) confront one another, it might not be as 'cut-and-dry'.

I therefore submit that it should not be contented outright that the Court in Le Roux $v$ Dey affirmed a universal standard of 'hurtfulness' that can be transplanted from delict into a different species of action under PEPUDA. It is my respectful submission that the Court affirmed the 'hurtfulness' standard as a part of the delictual matrix - as merely a part of the set of delictual requirements which operate in aggregate.

\section{(ii)}

\section{Objectiveness}

As noted above, the Constitution requires subjective intent through using the terms 'advocacy', 'hatred' and 'incitement'. 120 PEPUDA's breaks with that constitutional framework. It treats subjective (actual) intent as irrelevant. ${ }^{121}$

Modiri points out how Lamont J implicitly adopted a 'white' standard in surveying the facts. ${ }^{122}$ In doing so, Modiri is effectively making the legal realism and critical race theory case against the reasonable person standard because it is, through those lenses, inherently infected by indeterminacy or conscious and subconscious biases. In a similar vein, Milo, Penfold and Stein contend that formulation of section 10's intention test is vague. ${ }^{123}$

De Vos, too, criticises the standard, especially its employment by Lamont J in Afriforum v Malema (hereafter Malema). ${ }^{124}$ De Vos levels criticism against the judgment because of how it invites a judge to formulate and apply the standard of reasonableness in a seemingly impossible way - in complex matters which involve the assessment of 'hurt' on an objective, class-wide scale. Yet 'hurt' is inherently subjective. The 'purpose of hate speech regulation is to remedy the harm that it causes, whether to a target group or to the broader societal well-being'. 125

118 Islamic Unity (n 8) para 28; De Reuck (n 63) para 49.

119 Islamic Unity (n 8).

120 See paragraph 3.2 in this article. Teichner (n 56) 380; Milo et al (n 5) 83.

121 Milo et al (n 5) 87. Botha \& Kok (n 102) 25.

122 Modiri (n 106) 280-282.

123 Milo et al (n 5) 87.

1242011 (6) SA 240 (EqC); De Vos 2013 (n 66) https://constitutionallyspeaking.co.za/ qwelane-still-a-homophobe-but-his-challenge-to-hate-speech-clause-is-sound/.

125 Botha \& Govindjee (n 84) 13. Milo et al (n 5) 80, 81. 
At least in comparison to delictual actions the two leg test for hurtfulness is not to somehow legally aggregate and apply the subjective feelings of the class of persons. ${ }^{126}$ Instead it appears that the secondary objective test is to double-check and ensure that the initial subjective and individualised test fairly and reasonably gauges the hurtfulness. The secondary objective test is informed by various extrinsic contextual factors, i.e. constitutional values. ${ }^{127}$ The two leg test incorporating the reasonable person test in delict therefore makes sense. Under PEPUDA there is a single reasonable person test.

Botha and Govindjee note that hate speech regulation is purposed with remedying the effects of such speech and the harm that it causes, whether to a target group or to the broader societal wellbeing. ${ }^{128}$ Precisely because of the collective nature of the prohibited grounds on which our hate speech law is premised, the subjective nature of hurt must be abstracted from an individual circumstance and be tested on a 'behalf-of' basis'. Unlike in defamation cases relating to hurt, in hate speech the question becomes, 'What will hurt this person as a member of the group?'. This further begs the question: How does one accurately assess what is representative of the beliefs and sensitivities of an entire (and probably internally diverse) group of persons when one is not likely to be a member of the group? ${ }^{129}$ The consequence is a vague and indeterminate standard. De Vos pointedly illustrates the problem:

This means that religious and sexual minorities, say, might be entitled to special protection in terms of this Act and that a court should take note of the sensibilities of such groups when they judge whether a reasonable homosexual or a reasonable Muslim would have viewed a specific communication as having the intention to be hurtful to them.... Almost any cartoon that depicts the prophet Mohammed, say, might therefore constitute hate speech. Statements by a pastor that homosexuals are perverts that will burn in hell would also, most probably, constitute hate speech ... 130

A test of this nature makes sense when confronted with an obvious example of hurtful and hateful speech. Take the use of the ' $\mathrm{K}$-word'. It would be difficult, if not impossible, to defend its use outside of a bona fide artistic, theatrical or journalistic context. It is objectively hurtful and hateful, irrespective of what the utterer intends. Where

126 This is in respect of the claims of defamation and impairment of dignity. See Botha \& Kok (n 102) 27.

127 Le Roux $v$ Dey (n 111) para 179.

128 Botha \& Govindjee (n 84) 13.

129 And even where one is a member of the group, where the group is internally diverse, how is it possible for such a 'representative' to judge the matter on the behalf of the group's differing pluralities?

130 'Malema judgement: a re-think on Hate Speech needed' $P$ de Vos 12 September 2011 https://constitutionallyspeaking.co.za/malema-judgment-a-re-think-onhate-speech-needed/ (accessed 18 May 2019) (De Vos 2011). 
the utterer somehow has a benign intention, they must or ought to know the impact of the use of the ' $\mathrm{K}$-word'.

However, the section 10 test is not as 'clear-cut' when applied to all variances of expression, which might or might not be hurtful or construed as hateful. De Vos illustrates this by way of the example of genuine religious teachings, which may, in actuality, result in hurt but should not be prohibited merely because the reasonable person determines that the teacher could foresee the hurt arising nevertheless, continued expressing the content. ${ }^{131}$ Just because hurt is or might be occasioned does not mean, in employing the "clear intention test', that intention can be reasonably clear from the expression. Generally, the intention of the artist in sketching the cartoon or the Imam in preaching, save an indication to the contrary, is not to be hurtful, but could be for some other arguably legitimate purpose. ${ }^{132}$

As pointed out by Botha and Kok, the comparable common law actions relating to injury require, either the fault in the form of direct intention or dolus eventualis to be successful. ${ }^{133}$ These requirements have already been held to be constitutional in that they form part of a delictual matrix that straddles the fine line in protecting dignity without 'unjustifiably infringing the right to dignity'. ${ }^{134}$ In this case the comparison is apt. As Botha and Kok set out, the pure objective test in our current hate speech law sets the bar too low and occasions infringement too intense to be justified. ${ }^{135}$ Incorporating the fault requirement of intention into section 10 will raise the bar and might be a means of saving it in constitutional review.

\subsection{Reasonable and justified? Section 36(1) limitation...}

The Court appears to have set out an approach to the limitation of section 16 which grades the importance and 'protectability' of expression based on a scale of proximity to the core values of the right and our constitutional democracy. ${ }^{136}$ Expression in South Africa is therefore not measured by utility. It is important that the core is anchored in the text and values of the Constitution as opposed to being open-ended and determined by reference to a dominant class-

131 De Vos 2013 (n 66) https://constitutionallyspeaking.co.za/qwelane-still-ahomophobe-but-his-challenge-to-hate-speech-clause-is-sound/.

132 As above.

133 Botha \& Kok (n 102) 22.

134 Botha \& Kok (n 102) 25.

135 As above.

136 De Reuck (n 63) para 59. 
or prevailing cultural values, positions of morality or the prevailing wind of popular opinion. ${ }^{137}$

The limitation inquiry involves weighing the nature of the right against extent, purpose and means of the limitation in a proportionality assessment that considers all relevant factors. ${ }^{138}$ State interference is justified under transformative constitutionalism in order to secure the enjoyment of rights, especially by the vulnerable and historically oppressed. ${ }^{139}$ The purposes of the limitation by section 10 of PEPUDA are namely, the protection and advancement of equality and dignity, two fundamental rights.

As noted above, it is questionable whether there is a rational connection between the prohibition and its purpose. ${ }^{140}$ It may be possible that such suppression of speech in fact defeats the very purpose of section 10 in that it overregulates speech - and could cause a groundswell of defiant or subversive speech-activism. ${ }^{141}$

Furthermore, weighed against the purposes and means employed is the fact that freedom of expression has an increased importance (even invective speech) in a 'teething' democracy. This speaks to the extent and importance of the limitation on the right, especially where the right is of immense and momentous import.

In light of the above, it is doubtful that the limitations placed on the freedom of expression would or ought to survive constitutional scrutiny because they are overly broad and fail to sift good speech from bad (hate) speech. ${ }^{143}$

\section{Does the flag fit?}

Plainly, if section 10 were to be found unconstitutional, its formula would likely be adjusted to render it constitutional, through either judicial intervention or legislative action. ${ }^{144}$ However, inasmuch as

137 Moseneke (n 13) 315; See West Virginia State Board of Education v Barnette 538 US 343 (1943) (Justice Jackson held: 'The very purpose of a Bill of Rights was to withdraw certain subjects from the vicissitudes of political controversy, to place them beyond the reach of majorities and officials ...').

138 S v Makwanyane 1995 (3) SA 391 (CC) para 104; S v Manamela and Another (Director-General of Justice Intervening) 2000 (3) SA 1 (CC) para 33.

139 Klare (n 7) 154, 161-164.

140 Botha \& Govindjee (n 84) 27.

141 See paragraph 2.3 of this article. As is, in my own assessment occurring in US at present; not in response to legislative intervention, but in response to social movements (i.e. 'PC' or political correctness culture) and societal backlash. This 'organic regulation' has caused some quarters to feel threatened and is arguably one of the reasons that certain persons have been elected to high office.

142 See sec 36(1)(b) and (c).

143 Philips (n 69) para 28; Virginia v Black 538 US 343 (2003).

144 Judicial intervention following a finding of unconstitutionality might, for example, take the form of a reading-in or severance of words. 
that it is the existing legal regime, it is worth applying to the display of the old flag. ${ }^{145}$

The first stumbling block in applying section 10 to the flag is that the language of the statute is limited to 'publishing, propagating, advocating or communicating words'. A flag is clearly not comprised of words. 'Words' appears to be a bright and unequivocal palisade qualification to a case concerning 'speech' that is not 'speech'. Botha and Kok go as far as stating that other non-verbal forms of communication cannot fall within the ambit of section 10's hate speech provision. ${ }^{146}$

However, it is conceivable that a purposive and contextual interpretation could clear this hurdle. ${ }^{147}$ The argument is that the provision should not be frustrated by one restrictive word at odds with its intention and the intentions of the Act itself and should therefore be overlooked where the purpose demands. ${ }^{148}$ For the remainder of my assessment, I will assume that the qualification of 'words' does not present an insurmountable obstacle, so as to fully engage with the substance of this matter further.

The examination then turns to whether the flag, by its mere display, can bear an objectively inferred intention to cause hurt.

What seems to be required, for the spreading of hatred, or being hurtful, is the conveyance of sentiment to others, implying some sort of public display as regards the flag. This is because hatred is such an extreme emotional standard and because the flag has a range of calibrations, which are set according to context (conduct or words). For example, displaying the flag in private appears unlikely to amount to spreading hatred. Displaying the flag to others would likely amount to spreading hatred. ${ }^{149}$

If section 10's intention test can accommodate intention in the form of dolus eventualis, or intention of a comparable nature, then PEPUDA's objective test will likely be satisfied. ${ }^{150}$ Intention in the form of dolus eventualis requires the displayer to raise the flag having foreseen and reconciled themselves with the hurtful consequences that eventuate. ${ }^{151}$ If it can be shown that the reasonable person would realise, or is conscious of, the actual hurtful impact of the flag

145 It is also the existing enactment which is before Mojapelo DJP in South Gauteng High Court.

146 Botha \& Kok (n 102) 13, 14.

147 M Marais \& J Pretorius 'A contextual analysis of the hate speech provisions of the Equality Act' (2005) 18 PER 901, 906.

148 Marais \& Pretorius (n 147) 907.

149 Botha \& Kok (n 102) 12.

150 Botha and Kok address this matter and ultimately conclude that the section should be amended. See Botha \& Kok (n 103) 20, 25.

151 Botha \& Kok (n 102) 20, 25; Black v Joffe 2007 (3) SA 171 (C) para 39; S v Makgatho 2013 (2) SACR 13 (SCA) para 9. 
and what it represents, then they will be answerable for hate speech, even when they only harbour some benign intention. What would place displaying the flag as hate speech beyond doubt is where it is coupled with other words or conduct which relate to the symbolism of the flag and which indicate a hateful purpose in its display.

However, if the 'clear intention test' does not accommodate this form of intention in light of section 16 and its own formulation, and unless certain factors in the specific context of the case indicate positive intention, it is unlikely a clear objective intention can be inferred.

I submit that it is likely that the flag's inherent hurtfulness, in terms of section 10 of PEPUDA, warrants a court finding its display to be hate speech where it is displayed in public (or to others who would suffer hurt) outside of the ambit of section 12 of PEPUDA.

Such findings, notwithstanding the above, need to be on a caseby-case basis. The order sought by the Nelson Mandela Foundation relies precisely on the fault-lines of section 10 . The Foundation prays for a blanket classification of the gratuitous display of the flag as hate (and prohibited) speech. ${ }^{152}$ Such a classification would constitute prior restraint.

The Constitutional Court recognised the inherent danger of expression classification and censorship by prior restraint, in the context of the publication of illicit material, finding the legislation permitting such censorship unconstitutional. ${ }^{153}$ Although in Print Media South Africa and Another $v$ Minister of Home Affairs and Another (hereafter Print Media) the Constitutional Court was concerned with a provision allowing an administrative body to, before publication, review specific draft publications and therefore to censor specific publications, the Court noted that '[where an] administrative body is mandated and incentivised to classify, [it] also increases the likelihood of [prior] restraint'. 154

The implications are that were a court to declare any 'gratuitous display' of the flag as hate speech, the court would have classified the flag in a certain way (almost) regardless of the circumstances of other future cases. This would amount to a prior restraint through classification by curial edict and would supplant careful and considered analysis of the specific case of flag display. ${ }^{155}$

152 SAHRC https://www.sahrc.org.za/index.php/sahrc-media/news/item/1780-bidto-ban-old-racist-sa-flag (n 5); Ryan (n 5) https://www.groundup.org.za/article/ equality-court-asked-declare-old-sa-flag-hate-speech/.

153 Print Media South Africa and Another $v$ Minister of Home Affairs and Another 2012 (6) SA 443 (CC).

154 Print Media (n 153) para 59.

155 Print Media (n 153) para 66. 
Even if, on the specific facts of the case, the Foundation is granted the relief they sought, the Court should not hand down a broad prohibitory order, nor should it a definitive and absolute classification, for the reasons I set out above.

\section{Conclusion}

Hateful speech causes harm to intended targets and members of society alike. It erodes the fundamental values of our society in exposing our vulnerabilities to the elements of hate, violence and discrimination. Obviously the state is mandated to not only regulate but also prohibit expression that polarises and divides our society. However, it must do so in a manner that promotes the spirit, purport and object of our Bill of Rights and is reasonable and justifiable.

Specifically, the flag itself could be banned by law, but Parliament must pass such legislation, satisfy section 36(1) and supply certainty and stability therein. The role of the courts then, in furthering the transformative agenda of our Constitution, is to hold steadfast in balancing interests, testing for just outcomes and applying the law to further our constitutional ambitions.

As it stands, the flag may well constitute hate speech under PEPUDA. Whether this is a constitutionally permissible finding, in light of PEPUDA's probable constitutional flaws, is where the true debate must be located.

It is contended that it is open to Parliament to regulate hate speech in general but it must do so by sound constitutional means and not through a vague framework. It must not be heavy handed. It must be wary of not jeopardising the organic interaction and identity mapping in reaching transformative objectives that is crucial to our young democracy. 


\section{THE IMPACT OF THE 4th INDUSTRIAL REVOLUTION ON THE EMPLOYMENT RELATIONSHIP AND ADAPTIVE SKILLS REQUIREMENTS}

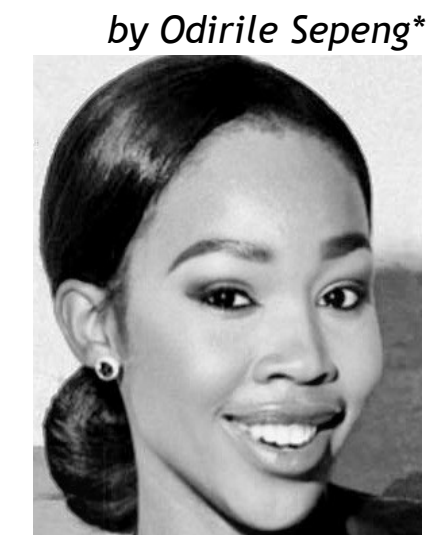

\section{Introduction}

The regulatory framework for labour is significantly influenced and informed by industrialisation, which ultimately shapes society and the future jobs. ${ }^{1}$ Three industrial revolutions were catalysts of industrialisation throughout world history. The first industrial revolution steam powered factories, the second was the application of science to mass production and manufacturing, and the third was the start into digitalisation. ${ }^{2}$ Presently, the 4IR gives attention to technological advancements which pose a threat to replacing human capital in the production process as it also threatens to blur the lines between reality and the virtual world. ${ }^{3}$ Technological developments

* Third year LLB student, University of Pretoria.

1 E Potenza 'All that glitters - what is industrialisation?' https://www.sahistory. org.za/archive/all-glitters-what-industrialisation-emilia-potenza (accessed 29 May 2019). See also M Weiss 'Re-inventing labour law?' In G Davidov \& B Langille (eds) The idea of labour law (2011) 234.

2 K Schwab 'The fourth industrial revolution' https://www.britannica.com/topic/ The-Fourth-Industrial-Revolution-2119734 (accessed 20 August 2019).

3 K Schwab 'The fourth industrial revolution' World Economic Forum on Africa 19 July 2016 https://www.weforum.org/about/the-fourth-industrial-revolutionby-klaus-schwab (accessed on 20 August 2019). 
have changed the traditional work organisation drastically as labour force is no longer homogeneous but rather segmented and fragmented into marginal groups and core groups. Furthermore, it is influenced by the rise of new forms of work and less traditional employment. ${ }^{4}$ This article reflects on the possible future of labour law as a response to industrialisation, particularly the 4IR.

First, I discuss the origin of the industrial revolution by reflecting on the first three industrial revolutions and the present 4IR. Second, I reflect on; 1) the possible impact of the 4IR on the employment relationship and 2 ) the new and/or adaptive skills requirements. Third, I present recommendations to respond to the fast-changing pace of labour and industrialisation suggested by the World Economic Forum (WEF). I thereafter conclude that the 4IR may be used as a vehicle to promote a socially affirmative interpretation of fairness in the labour context. This promotes a constitutional obligation to protect the interests of workers, in light of technological advancement, that have the potential to widen the income inequality gap.

\section{The historical development of the industrial revolutions}

The series of events that best describes the transformation of the first three industrial revolution is mechanisation of production; the introduction of mass production, and the digital revolution. ${ }^{5}$ The industrial revolution introduces new technologies and perspectives of the changing world in the economic and social orders. The first three industrial revolutions can be equated as the mechanisation of production; introduction of mass production and digital revolution. ${ }^{6}$ The first industrial revolution is known as 'the age of mechanical production', where the world relied less on agriculture and shifted towards manufacturing. This saw the rise of middle-class skilled workers. ${ }^{7}$ The second industrial revolution is known as 'the age of science and mass production' and this era created more jobs for skilled workers than the first industrial revolution. ${ }^{8}$ Steel, oil and electricity were used to power mass production. ${ }^{9}$ The third industrial revolution is known as 'the digital revolution' where electronics and information technology began to automate production and take

4 MM Botha \& E Fourie 'Decolonising the labour law curriculum in the new world of work' (2019) 28 Tydskrif vir Hedendaagse Romeins-Hollandse Reg 13.

5 Trailhead 'The four industrial revolutions' https://trailhead.salesforce.com/en/ content/learn/modules/learn-about-the-fourth-industrial-revolution/meet-thethree-industrial-revolutions.

6 Trailhead (n 5).

7 Trailhead (n 5).

8 Trailhead (n 5).

9 Trailhead (n 5). 
supply chains global. ${ }^{10}$ The progressive transformation from one revolution to another saw more people move into the cities as a result of mechanical production. Today, the 4IR is looming before us and it is characterised by machine learning and artificial intelligence. ${ }^{11}$

\subsection{What is the 4IR?}

For purposes of convenience the Fourth Industrial Revolution is referred to as $4 I R$. The $4 I R$ is characterised by technologies such as artificial intelligence, autonomous vehicles as well as the internet that has intergraded into our day to day lives. ${ }^{12}$ It builds on the digital revolution to enable the co-existence of physical and virtual production systems that are able to harmoniously co-operate on a global level. ${ }^{13}$ The difference between the third and 4IR, is the existing gap between digital, physical and biological orders that are now becoming one, as technology rapidly changes and integrates into human life. The unique additional extra features that the 4IR displays is the enhancement and possible opportunity to assist policy-makers, leaders and income groups to utilise technology to create a future human life. ${ }^{14}$ The revolution offers faster and efficient productivity, easily accessible connectivity and a general improvement in workplaces. ${ }^{15}$ This has reduced costs for human labour. ${ }^{16}$

It is further noted that the industrial revolutions had an impact on industrialisation in South Africa. ${ }^{17}$ Consequently, South Africa has drastically moved away from dependence on the agricultural and manufacturing sectors as significant drivers of economic growth. Research suggests that South Africa is currently a service economy, as the services sector contributes more than $45 \%$ towards the South African gross domestic product (GDP). ${ }^{18}$ The increased efficiency in production that is promised by the impending 4IR will incentivise the organisations in the services industry to substitute labour for capital. $^{19}$

This means that the implementation of 4IR inspired technology in the workplace would have a direct impact on the labour force and the

10 Trailhead (n 5).

11 Trailhead (n 5).

12 Trailhead (n 5).

13 Schwab (n 2) 12

14 Schwab (n 2) 17.

15 Regus 'The workplace revolution' https://www.iwgplc.com/WhitePapers/theworkplace- revolution-regus-january-2017.pdf (accessed 10 October 2019)

16 Schwab (n 2) 23.

17 E Potenza 'All that glitters - What is industrialisation?' https://www.sahistory. org.za/archive/all-glitters-what-industrialisation-emilia-potenza (accessed 29 May 2019).

18 'South Africa's GDP' https://www.southafricanmi.com/south-africas-gdp.html (accessed 30 May 2019).

19 Schwab (n 2) 16. 
employment relationship that exists between employers and employees.

\section{The impact of the 4IR on the employer- employee relationship}

The traditional cornerstone of labour law comprises of an indefinite contract, with a single employer centred around a fundamental concept of permanent employment. This contract, which is typified by employees traditionally engaging in a workplace over which the employer organises work, exercises physical control and directs how employees should do it, is being abraded. ${ }^{20}$ Labour law has traditionally been concerned with the unequal bargaining power in an employment relationship. ${ }^{21}$ As such, Botha and Fourie recognise that such inequalities negatively impact an employee's livelihood. ${ }^{22}$ Rycroft and Le Roux advocate for fair labour practices in favour of the employee and their view is influenced by the changing 4IR. ${ }^{23}$

Contemporarily, and in the future, it is likely that work will be performed by someone who receives instruction on-line, works from home with full autonomy, delivers the agreed services or product(s) on-line, and is paid on-line. ${ }^{24}$ According to Thompson, these more propitious forms of practice(s) may have advantages for those employees aspiring for maximum flexibility, however, they predominantly offer less protection to workers than the traditional model of employment. ${ }^{25}$ The decolonisation of labour law would see the employment relationship achieve more than merely a masterservant relationship which has traditionally stifled the contracting of an employment relationship. ${ }^{26} \mathrm{New}$ forms of 'worker' have emerged, such as the 'zero hour' contract, the 'Uber driver' and the 'e-lancer' who are based on the road and at home. ${ }^{27}$ The 4IR introduces new risks, conditions and new working environments through innovative technology. 28 The emergence of the 'gig economy' in which services are provided on demand whilst being driven by a technology platform, has brought the discussion on contingent forms of practice into sharp focus. ${ }^{29}$ Therefore, the traditional employment relationship needs to

20 A Van Niekerk \& N Smit (ed) Law@work (4th ed) (2018) 35.

21 AJ Rycroft \& R Le Roux 'Decolonising the labour law curriculum' (2017) 38 Industrial Law Journal 1483.

22 Botha \& Fourie (n 4) 6.

23 Rycroft \& Le Roux (n 21) 1482.

24 Van Niekerk \& Smit (n 20) 5.

25 C Thompson 'The changing nature of employment' (2003) 24 Industrial Law Journal 1815.

26 Rycroft and Le Roux (n 21) 1483.

27 Botha \& Fourie (n 4) 13.

28 Botha and Fourie (n 4) 12.

29 For example, Uber transport. See also Van Niekerk \& Smit (n 20) 5. 
increasingly be on scalable adaptability as well as empowering people rather than corporation as seen with the first three revolutions. This means that the human resource practitioners will take on a critical role in articulating and defining the terms and conditions of work contracts to ensure that the labour experience promotes a more flexible work environment and accommodates artificial intelligence and the advancement of human capital. ${ }^{30}$ Weiss argues that employment labour is not a commodity and therefore the employment relationship should promote the employee's human dignity. ${ }^{31}$ The International Labour Organisation's (ILO) recommendations propel a sustainable development of the labour force through economic growth and improved distribution of income. ${ }^{32}$ Le Roux rightly refers to this as the sustainable employment and good governance, which encapsulates the best interests of the parties involved. ${ }^{33}$ Weiss further recognises the redundancy of traditional modes of employment and suggests that the labour market is moving into virtual entities as embodied by the 4IR. ${ }^{34}$ The concern is employing labour law to adapt to the new order, whilst simultaneously protecting the employee's interest. ${ }^{35}$

\section{The impact of the 4IR on new and adaptive skills requirement}

The fast-changing evolution of innovative technology and its disruptive impact on the development on the socio-economic order leads to the transformation of industries and how businesses structure themselves. ${ }^{36}$ The employment relationship will be changed, as employers will demand current and innovative skills. Employees will also be forced to upskill and develop new sets of skills. An example of this concept is the introduction of machine learning and robots. ${ }^{37}$ This phenomenon will not necessarily eradicate all professions however, there will be a substitution of certain tasks carried out by such

30 Botha and Fourie (n 4) 12.

31 Weiss (n 1) 44.

32 As above.

33 Rycroft \& Le Roux (n 21) 1129.

34 Weiss (n 1) 45. Although Weiss does not directly refer to the 4IR, he mentions those factors that characterise the impending 4IR such as virtualisation, technological changes, less traditional employment, and new forms of work.

35 Botha and Fourie ( $\mathrm{n}$ 4) 7.

36 L Omarjee Fin 24 'We can't predict job losses due to the 4th industrial revolution -labour minister' 15 March 2019 https://www.fin24.com/Economy/Labour/wecant-predict-job-losses-due-to-the-4th-industrial-revolution-labour-minister20190315-2 (2 September 2019).

37 World Economic forum 'The future of jobs, employment, skills and workforce strategy for the fourth industrial revolution' http://www3.weforum.org/docs/ WEF_Future_of_Jobs.pdf (2 September 2019) 58. 
machines. This will see more and more employees with more time and the opportunity to adapt and learn new skills. ${ }^{38}$

Tshilidzi Marwala used the example of the introduction of artificial intelligence on stock trading, where human traders were replaced by artificial intelligent traders. ${ }^{39}$ The emotional aspect is therefore removed from the markets and the decisions are purely objective and therefore made on data only. Trade markets have seen the shift of relying on human skills of shouting aloud and using height as an advantage to be seen when shouting prices. ${ }^{40}$ However, human beings no longer control the stock market as many are using computers to trade in stock markets. This has seen a far more efficient stock trading market. ${ }^{41}$ In the same light, professionals in the banking sector traditionally needed accounting skills. However, now the banking sector should expand their skills as future bankers must have an understanding for technology. This is evident in the closing of walk in bank branches in order to accommodate an even quicker, convenient and efficient online banking method. ${ }^{42}$

Such adaptability of skillsets to the change of industrialisation is through multi-disciplinary education, where human and social sciences accommodate science and technology. This includes skills such as social skills, complex problem solving skills, content skills, process skills, systems skills, cognitive abilities and physical skills. ${ }^{43}$ । recommend the section 213 of the Labour Relations Act (the LRAct) definition of an employee be reconsidered to include the upcoming changes as introduced by the $4 \mathrm{IR} .{ }^{44}$ In recognising that labour law does not exist in isolation, together with Weiss, Rycroft and Le Roux firmly hold that the law should respond to the unequal societal labour issues including minimum wage, parental leave, disputes and strike actions. $^{45}$

\section{Conclusion: Recommendations}

The need for rapid adjustment to the new disrupted sphere is vital for all stakeholders. Taking government as an example, it would be advisable to consider the inclusion of innovative approaches within

38 Omarjee (n 36).

39 A Chauke 'Jobs and skills in the fourth industrial revolution' 18 December 2018 https://www.sanews.gov.za/features-south-africa/jobs-and-skills-fourthindustrial-revolution (2 September 2019).

40 As above.

41 As above.

42 As above.

43 As above.

44 The Labour Relations Act 66 of 1995.

45 Staff Writer Business Tech ' 3 manor new labour laws that every South African needs to know about' https://businesstech.co.za/news/business/264791/3major-new-labour-laws-that-every-south-african-needs-to-know-about/

(accessed 15 October 2019). 
education and labour-related regulation and policy making. ${ }^{46}$ This would entail that a new set of skills would be developed. When looking at education and training institutions, it would be vital to look into new business models and strategies in providing products for employees who need to apply new skill sets, entrepreneurs who will require an innovative outlook regarding product and service delivery, as well as the private and public sector. ${ }^{47}$ It would be recommendable for businesses to invest in the new opportunities when developing talent because looking into the future, workforce will be the heart of a sustainable business development. It is finally dawning on firms that, the days of merely waiting on human capital to serve in the firm are soon ending. They would now have to adopt a new outlook in achieving their skills and talents out of necessity and with a sense of urgency. The WEF recommends seven immediate and long-term ways to respond to the possible impact of the 4IR on both the employment relationship and adaptive skills. ${ }^{48}$

Businesses can reinvent the Human Resources function by managing skills disruption as a matter of urgency. When looking at talent development, it can no longer be deemed as a long-term issue that could be resolved by traditional counter-fit solutions that were tested in the past, or by merely substituting talents. It is vital to consider proactive and innovative skill-development as a response to the changing industries. This would require that the HR departments of the various firms delegate to identify skill gaps and advise the organisation to shift their strategies to optimise on transformative trends. ${ }^{49}$ Secondly, businesses should make use of data analytics in order to build a new approach to workforce planning and talent management in order to improve data forecasting. By making use of such data, firms would be able identify and optimise on new and emerging skills as a form of responding to the changing working environment. 50

Furthermore, businesses can benefit from a diverse and talented workforce. This diversity can be in terms of age, gender, race or sexual orientation. The use of technology can assist businesses to identify the neglected biases in recruitment processes. This can be achieved through advertisement or better understanding of the workplace culture in order to stimulate a better working environment. With the recent changes and blurs in physical and organisational boundaries, it would be vital for firms to consider capitalising on flexible working arrangements and encourage online talent platforms. The way in which firms usually manage people's 
performance will change as more people are able to connect and collaborate independently through digital frameworks. Such collaboration will see the need for modern digital trade unions and updated regulatory provisions, which suit the changing working environments. ${ }^{51}$

Technological trends introduced by the 4IR will introduce many new cross-functional roles for which employees will need both technical and social and analytical skills. Therefore, it would be recommendable for businesses to rethink about education systems as $65 \%$ of children who are in the primary educational phase will enter the workforce when the job types have been created. ${ }^{52}$ Reactive work, as a concept, will cease to exist. Instead, it will be replaced by discretionary ability and out of the box thinking.

It would be vital for firms to also incentivise on lifelong learning. When looking at it from a company perspective, the firms would need to continuously upskill and reskill their employees. ${ }^{53}$ The collaboration between the public and private sectors on talent issues will offer firms the opportunity to partner up and develop future skills and employment needs as opposed to seeing each other as competition. Businesses will need to engage with government on strategies that shift away from redundant skills between the sectors and address cost concerns and social stability. ${ }^{54}$

51 As above.

52 World Economic forum 'Releasing human potential in the fourth industrial revolution, an agenda for leaders to shape the future of education, gender and work' http://www3.weforum.org/docs/WEF_EGW_Whitepaper.pdf (2 September 2019) 45.

53 World Economic forum (n 37) 59.

54 World Economic forum (n 37) 62. 


\section{THE ROLE OF LAW AND GOVERNANCE IN ADVANCING CLIMATE RESILIENCE AND CLIMATE JUSTICE}

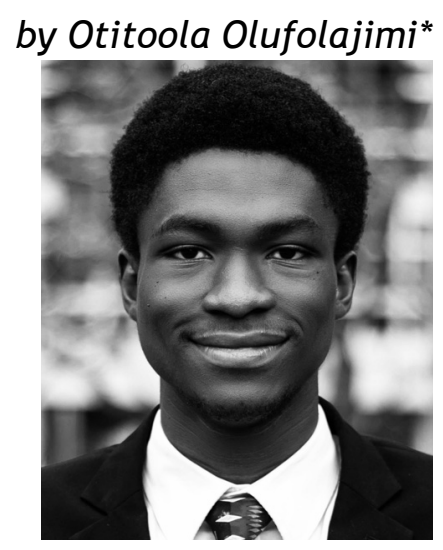

\section{Introduction}

'... but in this world nothing can be said to be certain, except death and taxes'. ${ }^{1}$ Climate change is a lot like death. We all understand that it is inevitable, but few of us truly accept it. Climate change is more than an environmental issue. Many of its consequences are social, economic and humanitarian. The past century has witnessed unprecedented human impacts on the natural environment. The United Nations listed 816 species that have become extinct and 11,046 species that are threatened with extinction. ${ }^{2}$ Nearly $25 \%$ of the world's most important marine fish stocks are depleted, overharvested or just beginning to recover from overheating. Another $44 \%$ are being fished at their biological limit and are therefore

* $\quad$ Fourth Year, LLB, University of Lagos, Nigeria. otitoolafolajimi@gmail.com.

1 B Franklin The private correspondence of Benjamin Franklin: comprising a series of letters on miscellaneous, literary, and political subjects: written between the years 1753 and 1790; Illustrating the memoirs of his public and private life, and developing the secret history of his political transactions and negotiations (1817) 1706.

2 United Nations Commission on Sustainable Development Global Status of Biological Diversity [E/CN,17/2001/PC/18] New York (2001). 
vulnerable to depletion. ${ }^{3}$ In 2006, 1 out of 5 people in the developing world did not have reasonable access to safe drinking water (as defined by the United Nations), and roughly 2 out of every 5 did not have basic sanitation. ${ }^{4}$ The global rate of deforestation averaged 9 million hectares per year in agricultural land worldwide and this has undoubtedly become a major issue. ${ }^{5}$ Issues such as species extinction, industrial pollution, forest loss, ecosystem degradation, overfishing and degraded freshwater supplies are all part of our contemporary world. $^{6}$

Climate change is a threat to the earth and sustainable development. There is no country in the world that is not experiencing first-hand, the drastic effects of climate change. ${ }^{7}$ Indeed, a large section of the global population already suffers or is in some way affected by the adverse effects of climate change, including its impacts on agriculture, aquaculture, livelihoods, biological diversity, health and a broad range of human rights. Although the impacts of climate change are felt globally, developing countries will bear the brunt of their social, economic and environmental effects. The populations living in the world's least developed countries are significantly more vulnerable to the consequences of a changing climate, while their 'carbon footprint' is negligible as compared to that of developed countries. Developing countries are more vulnerable to the impact and repurcussions of climate change because they have fewer resources needed to adapt. The 2011 UNDP Human Development Report and annual Intergovernmental Panel on Climate Change (IPCC) reports provide overwhelming evidence that we are reaching an upper limit of our capacity to emit greenhouse gases (GHGs) without dire consequences. ${ }^{8}$ Furthermore, global warming is causing long-lasting changes to our climate system, and these changes are sure to morph into irreversible consequences if we do not take immediate action. The annual average losses from earthquakes, tsunamis and flooding amount to hundreds of billions of dollars, requiring an investment of $\$ 6$ billion annually in disaster risk

3 United Nations World Resources Institute World Resources 2000-2001: People and ecosystems (2000) https://wriorg.s3.amazonaws.com/s3fs-public/pdf/world_ resources_2000-2001_people_and_ecosystems.pdf (accessed on 25 July 2018).

4 LR Brown \& L Starke State of the world 2004: A World Institute Report on progress toward a sustainable society (2004) at 7.

5 United Nations World Resources Institute Guide (n 3).

6 W Thomas 'Rio's unfinished business: American enterprise and the journey toward environmentally sustainable globalization' (2002) 32 Environmental Law Reporter at 10875.

7 United Nations on Sustainable Development Goals 'Goal 13: climate action' https://www.undp.org/content/undp/en/home/sustainable-development-goals/ goal-13-climate-action.html (accessed 2 August 2018).

8 United Nations on Development Programme 'Sustainability and equity: a better future for all' (2011) https://sustainabledevelopment.un.org/?menu=1300 (accesed 20 July 2018); Intergovernmental Panel on Climate Change 'Climate change: impacts, adaptation, and vulnerability' Working Group II, 5th Assessment Report (2014) https://www.ipcc.ch/report/ar5/wg2/ (accessed on 19 July 2018). 
management alone. ${ }^{9}$ One of the major aims of the United Nations Development Programme (UNDP) for Sustainable Development is to address the needs of developing countries and help mitigate climaterelated disasters; helping more vulnerable regions adapt to climate change through effective resilient approaches and climate justice. ${ }^{10}$

Climate resilience means the capacity for a socio-ecological system to adapt, reorganise, and evolve into more desirable configurations that improve the sustainability of the system, leaving it better prepared for future climate change impacts. ${ }^{11}$ Furthermore, climate resilience can refer to actions that either reduce climate impact or respond to climate impact. The concept of resilience has developed as communities, governments, and businesses gear up efforts to manage the unavoidable negative consequences of events tied to such trends. The degree to which a system - be it a society, a community, or the environment - can be resilient depends on its ability to be aware, diverse, self-regulating, integrated, and adaptive. Climate justice, on the other hand, is generally used as a term for viewing global warming as an ethical issue and considering how its causes and effects relate to concepts of justice, particularly environmental justice and social justice. This can mean examining issues such as equality, human rights, collective rights and the historical responsibility in relation to climate change. Equity and fairness are important sub-concepts of climate justice. They relate to both the processes through which decisions about how to address climate change are made (i.e. procedural justice), and the ways in which the costs of mitigation and adaptation are distributed (in other words, distributive justice).

The reason climate resilience and justice would be contemplated is because of the catastrophic effects of climate change. Thus, climate change results in great environmental impact beyond temperature increases, including sea level rise, melting glaciers and reduced snow cover, extreme weather events, erratic precipitation, droughts and flooding. ${ }^{12}$ The atmosphere is under undue pressure because of emissions of catastrophic substances to the air.

Governance provides us with a broad term for understanding the institutions working across the state, market and civil society. The law is there to ensure justice. Law and governance improvements can be part of the solution - or can be obstacles to progress - in addressing climate change. Modern state citizens have acquired new

9 United Nations on Sustainable Development Goals (n 7).

10 As above.

11 Wikipedia 'Climate resilience' https://en.wikipedia.org/wiki/Climate_resilience accessed (17 September 2018).

12 Centre for International Sustainable Development Law 'Law, governance and climate change' https://www.cigionline.org/sites/default/files/workshop_lima_ peru_2014_web_1.pdf (accessed 12 September 2018). 
rights, which are as inalienable as those rights which nature endows on them. Increasingly important in some countries is the right to a decent and healthy environment. ${ }^{13}$ A number of existing human rights rely on a safe climate for their complete realisation. These include many civil, political, economic, social and cultural rights. For example, the rights to life, health, adequate standard of living, property, self-determination and just and favourable conditions of work, may all rely on conditions of a safe climate. ${ }^{14}$ However, climate change must go hand in hand with efforts to integrate disaster risk measures into national strategies. It is still possible, with the political will and a wide array of technological measures, to limit the increase in global mean temperature to $2^{\circ} \mathrm{C}$ above pre-industrial levels. This requires urgent collective action. ${ }^{15}$ And, if efforts are not geared towards sufficient climate resilience and advancement in climate justice, the atmosphere together with the society, are likely to face undue impact as injustice anywhere is a threat to justice everywhere. It is essential that civil society groups and other institutions involved in climate adaptation activities have a strong and locally driven understanding of the vulnerability of the poorest and most at-risk communities.

Poor governance and weak institutions are often cited as the main drivers of vulnerability, and lack of local participation and investment in community-based climate adaptation strategies are significant barriers to a community's adaptive capacity. ${ }^{16}$ Thus, it is important to increase awareness, beckon and even advise the government, civil societies, legal professionals and even the private sector, to develop adaptation solutions in line with the scale and scope of climate change. Therefore, it means that the burning issue of climate resilience and climate justice is for all to be involved in ensuring a peaceful and calmer world.

\section{Advancing climate resilience and climate justice}

The question of who suffers most from climate injustice yields different answers, depending on who one thinks the main referent object of climate justice should be. A state-centric approach to

13 E Okon 'The Constitution and the protection of the environment in Nigeria' in Epiphany Azinge and Adedeji Adekunle (eds) Administration of justice and good governance in Nigeria (2011) 253.

14 C Giorge 'Role of nongovernmental organizations in the climate change negotiations' (1998) 9 Colorado Journal of International Environmental Law and Policy at 115.

15 As above.

16 International Rivers 'Civil society guide to healthy rivers and climate resilience' https://www.internationalrivers.org/sites/default/files/attachedfiles/intlrivers _civilsocietyguide2013.web_.pdf (accessed 27 September 2018). 
climate justice places the historical responsibility for the majority of all GHG emissions, and thus the responsibility for mitigating action, on the world's 'old' industrialised countries while simultaneously emphasising developing countries' right to lift their populations out of poverty, including through energy intensive industrialisation. It also focuses on how States rather than sub-state groups or individuals might be perpetrators of climate injustice.

An inter-generational perspective on climate justice stretches the time horizon by emphasising current generations', and especially States', responsibility to preserve the planet and its resources for future generations who, unlike present generations in both developed and developing countries, have no lobby at all to influence global climate negotiations. Intergenerational equity presupposes State rights and obligations. ${ }^{17}$ Article 3(1) of the United Nations Framework Convention on Climate Change (UNFCCC) recognises that climate change is fundamentally an intergenerational problem. ${ }^{18}$ It states that: parties should protect the climate system for the benefit of present and future generations of humankind, on the basis of equity and in accordance with their common but differentiated responsibilities. This incorporates the principles of intergenerational and intragenerational responsibility, which clearly addresses the linkage between equity and the "common but differentiated responsibilities' principle. It specifies that the parties should protect the climate system for the benefit of present and future generations of mankind, on the basis of equity and in accordance with their common but differentiated responsibilities and respective capabilities. The relationship between intergenerational and intragenerational equity can be illustrated in two ways. First, it can be described as a conditioning relationship, in which the fulfillment of intragenerational equity is a necessary condition for achieving intergenerational equity. Second, it inherently implies a conflicting relationship, which entails competition for limited resources i.e., whether limited resources should be used to satisfy the urgent needs today or for the long-term protection of future generations.

17 E Brown Weiss 'Climate change, international equity and international law' 9 Vermont Journal of Environmental Law 615 at 616. See also C Batruch 'Hot air' as precedent for developing countries? equity considerations' $(1998 / 1999) 17(1)$ UCLA Journal of Environmental Law and Policy at 45.

18 United Nations Framework Convention on Climate Change 29 May 1992, entered into force: 21 March 1994 https://unfccc.int/resource/docs/convkp/conveng.pdf (accessed on 26 July 2018). See also Principle 3 of the Rio Declaration states that: 'The right to development must be fulfilled so as to equitably meet developmental and environmental needs of present and future generations' 874 entered into force: 14 June 1992) http://www.unesco.org/education/pdf/ RIO_E.PDF (accessed on 27 July 2018); the Stockholm Declaration of the United Nations Conference on the Human Environment proclaims that 'man ... bears a solemn responsibility to protect and improve the environment for present and future generations' (1972). 
A social justice perspective emphasises the responsibility of affluent people, again in both developed and developing countries, towards those who are most vulnerable and least capable of adapting to the adverse impacts of climate change: the world's poor and marginalised. The world's oil producing states have claimed that a transition to renewable energies and a 'green' world economy is unfair to their citizens whose livelihoods depend on oil revenues thus, they have demanded they be compensated for their losses. This, too, is part of the climate justice discourse. It must be stated that intergenerational equity is a form of social justice.

It should be obvious that climate justice is an inherently contested concept. Justice can be used to validate completely opposing strategies and sometimes, to simply defend vested interests or rights. Therefore the challenge for an ethical debate is to relate justice not only to single aspects but to view it from an overall, comprehensive perspective. The concept of justice should be universal, so that it is comprehensible and generally acceptable to all parties, regardless of whether they live in industrial or developing countries.

Despite this, there is no doubt, the government, legal community and civil society groups have the finance and human resources to help mitigate the effects of climate change and ensure climate justice for sustainable development. ${ }^{19}$ Thus, they have huge roles to play in ensuring the world is a better place for everyone. There have been identified ways to advance and build resilience to the climate. The first is to reduce exposure; in the sense that there is a fundamental difference between climatic and non-climatic shocks; because most of the shocks on-farm can be reduced at the source, or limited in their extension, contrary to climatic shocks. ${ }^{20}$ The second is to reduce the sensitivity of systems to shocks. Sensitivity to drought can, for

19 Sustainable development requires managing many threats and risks, including climate change. Because climate change is a growing threat to development, sustainability will be more difficult to achieve for many locations, systems, and populations unless development pathways are pursued that are resilient to effects of climate change. However, a number of studies recognise that not every possible response to climate change is consistent with sustainable development, as some strategies and actions may have negative impacts on the well-being of others and of future generations. See F Denton \& T Wilbanks 'Climate-resilient pathways: adaptation, mitigation, and sustainable development' available at https://www.ipcc.ch/pdf/assessmentreport/ar5/wg2/WGIIAR5-Chap20_FINAL. pdf (accessed 18 September, 2018).

20 Here, the best example is probably the eradication of rinderpest, which has totally suppressed a major risk for livestock and those depending on it. The use of shocks is in consonance with the author's definition of resilience as: resilience can be described as the capacity of systems, communities, households or individuals to prevent, mitigate or cope with risk, and recover from shocks. At first approximation, resilience is the contrary of vulnerability, but importantly it adds a time dimension to the concept: a system is resilient when it is less vulnerable to shocks across time, and can recover from them. See V Gitz \& A Meybeck, 'Risks, vulnerabilities and resilience in a context of climate change' available at http://www.fao.org/3/ai3084e/i3084e03.pdf (accessed 17 September, 2018). 
instance, be reduced by using drought-resistant varieties or keeping stocks of hay and to increase adaptive capacity. This includes considering the modifications of a system, taking into account all the potential shocks and changes altogether (to take into account compensating, cumulative or exacerbating effects). ${ }^{21}$

Those particularly susceptible to the adverse effects of climate change are the world's poor, 'low-lying and other small island countries; countries with low-lying coastal, arid and semi-arid areas or areas liable to floods, drought and desertification, and developing countries with fragile mountainous ecosystems. ${ }^{22}$ Climate resilient pathways include strategies, choices, and actions that reduce climate change and its impact. They also include actions to ensure that effective risk management and adaptation can be implemented and sustained. ${ }^{23}$

Although insurance is an effective risk transfer instrument, it is far too seldom used in developing nations. Schemes can offer victims compensation in the case of loss from climate change, and to some extent, climate injustice. This is particularly important for the poorest and most vulnerable countries and people, because extreme weather events such as hurricanes or droughts can threaten their very existence. ${ }^{24}$

In addition, sustainable management, preservation, conservation and utilisation of natural resources culminates into environmental protection to advance climate resilience. The UN Human Rights Council has included climate change and human rights on its agenda, and has issued several resolutions in which they acknowledge that climate change is a threat to human rights. ${ }^{25}$

The courts, legal practitioners, civil societies, the government can effectively press for climate actions, thereby enhancing transparency, ensuring accountability of the perpetrators of climate injustice, and integrating human rights into climate actions.

21 United Nations on Sustainable Development Goals (n 7).

22 As above.

23 F Denton \& T Wilbanks 'Climate-resilient pathways: adaptation, mitigation, and sustainable development' available at https://www.ipcc.ch/pdf/assessment report/ar5/wg2/WGIIAR5Chap20_FINAL.pdf (accessed 18 September, 2018).

24 'Climate-related loss and damage: Finding a just solution to the politica challenges' available at https://www.brotfuerdiewelt.de/fileadmin/mediapool/ 2_Downloads/Fachinformationen/Profil/Profil19_E_LossAndDamage.pdf (accessed 19 September, 2018).

25 Human Rights Council Resolutions 7/23 (2008); 10/4 (2009); 18/22 (2011). 


\subsection{Environmental ethics and climate change: Between anthropocentrism and ecocentrism}

Before analysing the different roles of the government, civil society and the legal community in advancing climate resilience and justice, it is important that we understand the underlying theories that guide environmental actions globally. This will help in understanding the effect of certain environmental actions which cause climate change. This is called Environmental Ethics.

Environmental ethics is defined as the moral relationship between humans and the natural environment, including nonhuman individuals that populate/constitute it. ${ }^{26}$ Ecocentrism and anthropocentrism are recognised as one of the common ecological moral dilemmas. ${ }^{27}$ Anthropocentrism, in its original connotation in environmental ethics, is the belief that value is human-centred and that all other beings are means to human ends. ${ }^{28}$ The anthropocentric ethic holds that only human beings have moral values and that the ecosystem represents a mere stock of natural resources for satisfying human needs. ${ }^{29}$ It takes a human-centred, or anthropocentric, view of our relationship with nature to emphasise the value of securing the resources needed for further development. Many have argued that anthropocentrism is inevitable and even benign for the aim of environmental protection. ${ }^{30}$ Whereas others argued that anthropocentrism is inadequate for biodiversity conservation. ${ }^{31}$

Ecocentrisim, on the other hand, takes an environment-centred, or ecocentric, view of our relationship to nature to emphasise the value of conserving her integrity and beauty. Environmentally concerned authors have argued that anthropocentrism is ethically wrong and at the root of ecological crises. ${ }^{32}$ That a more fundamental change in the economy, technology, values and attitudes is required

26 R Sandler 'Environmental ethics, overview' 2 Encyclopedia of Applied Ethics (2012) at 105.

27 United Nations Global status of biological diversity [E/CN.17/2001/PC/18] (2001).

$28 \mathrm{H}$ Kopnina and others 'Anthropocentrism: More than just a misunderstood problem' (2018) 31(1) Journal of Agricultural and Environmental Ethics at 109110.

29 TG Jakobsen 'Thinking like a mountain: encountering nature as an antidote to humankind's hostility towards the earth' (2019) 18(1) Journal of Critical Realism at 46.

30 BG Norton 'Environmental ethics and weak anthropocentrism' (1984) 6(2) Environmental Ethics 131-148; A Weston 'Beyond intrinsic value: Pragmatism in environmental ethics' (1985) 7 Environmental Ethics at 321-339; W Grey 'Anthropocentrism and deep ecology' (1993) 71(4) Australasian Journal of Philosophy 463-475.

31 PJ Cafaro \& RB Primack 'Species extinction is a great moral wrong' (2014) 170 Biological Conservation at 1-2.

32 See H Kopnina and others "The "future of conservation" debate: Defending ecocentrism and the nature needs half movement' (2018) 217 Biological Conservation 140-148. 
for the protection of the environment according to them goes without saying. ${ }^{33}$ They propose an ecocentric approach to matters of environmental concerns. The recognition of the intrinsic value of the environment is the focus of the ecocentric approach to environmental protection. ${ }^{34}$ This, because there are deficiencies inherent in the anthropocentric perspective. First, the anthropocentric perspective fails to protect the integrity of the biosphere in and of itself. Then, the anthropocentric perspective emphasises human domination over nature and therefore, the interests of nonhuman species are easily ignored or sacrificed. An adequate environmental ethic must not be limited to consideration of individual interests and no successful environmental ethic can be derived from a purely individualistic approach. ${ }^{35}$

Some environmental ethicists argue, however, that critics of anthropocentrism are misguided or even misanthropic. ${ }^{36}$ They state that the term anthropocentrism is often misused as a criticism of humanity as a whole, and that this is counterproductive for environmental protection, and even misanthropic. ${ }^{37}$ They contend: first that criticism of anthropocentrism can be counterproductive and misleading by failing to distinguish between legitimate and illegitimate human interests. ${ }^{38}$ Legitimate concerns include the need to care for other members of one's own species; and illegitimate concerns include species-ism and human chauvinism. ${ }^{39}$ This is when humans give preference to the interests of members of their own species over the interests of members of other species for morally arbitrary reasons. ${ }^{40}$ Thus, it is not anthropocentrism but species-ism and human chauvinism that are 'bad'.

Their second contention is that, humans differ greatly with regard to their environmental impact, and consequently, addressing human inequalities should be a precondition for environmental protection. ${ }^{41}$ That is, it is unhelpful to criticise humanity in general for practices carried out by a limited number of people, when many others may in fact oppose them. ${ }^{42}$ This is because indeed, many indigenous societies

T Hayward Ecological Thought: An Introduction (1995) at 56.

T Hayward 'Anthropocentrism: A misunderstood problem' (1997) 6(1) Environmental Values 2.

Norton (n 30) 135.

See D Kidner 'Why 'anthropocentrism' is not anthropocentric' (2014) 38(1) Dialectical Anthropology 465-480

Hayward (n 34) at 51.

As above.

Hayward (n 34) 51 \& 59.

Hayward (n 34) 52.

LE Sponsel 'Human impact on biodiversity: Overview' in SA Levin (ed) Encyclopedia of biodiversity (Vol 4) (2014) at 58-59. See also MA Andrich, $\mathrm{J}$ Imberger \& ER Oxburgh 'Raising utility and lowering risk through adaptive sustainability: Society and wealth inequity in Western Australia' (2010) 3(3) Journal of Sustainable Development at 14-35.

Hayward (n 34) 58. 
were not anthropocentric, but industrial Western society has become so. ${ }^{43}$ Furthermore, not all humans benefit from the exploitative activities of some humans. ${ }^{44}$ When the exclusive benefits of exploitation are unacknowledged, the 'anti-anthropocentrists are left vulnerable to ideological rejoinders to the effect that challenging those activities is merely misanthropic'. ${ }^{4}$ Indeed, some scholars have accused environmentalists of putting the blame for biodiversity loss on all humanity, rather than over-exploitive elites. ${ }^{46}$ Given the many documented social ills of inequality, it is often assumed that inequality is an important factor to consider when predicting biodiversity loss. 47

Third, since ecosystems constitute the 'life-support system' for humans, anthropocentrism can and should be a powerful motivation for environmental protection. ${ }^{48}$ That is, human and environmental needs coincide because maintaining the environment for human material benefit is the strongest motivation for nature protection. ${ }^{49}$ Anthropocentric motivation is favoured as the best argument for maintaining the ecological systems on which we depend, ultimately converging into the same practical outcomes as ecocentric positions. ${ }^{50}$ Illustrative of this position is the statement of the World Charter for Nature of the United Nations General Assembly (UNGA), which calls for non-wasteful use of natural resources and observes that humanity benefits from healthy ecological processes and biological diversity. ${ }^{51}$ This is in line with the anthropocentric ambition to guarantee environmental protection in order to benefit humanity as a whole.

43 Sponsel (n 41) 137.

44 Hayward (n 34) 59.

45 As above.

46 M Chapin 'A challenge to conservationists' World Watch (2004) 17 at 21. See also $\mathrm{G}$ Holmes 'Exploring the relationship between local support and the success of protected areas' (2013) 11 Conservation and Society at 72-82; R Fletcher \& B Buscher 'Why EO Wilson is wrong about how to save the earth' (2016) available at https://aeon.co/opinions/why-e-o-wilson-is-wrong-about-how-to-save-theearth (accessed 20 September 2018).

47 TG Holland, GD Peterson, \& A Gonzalez 'A cross-national analysis of how economic inequality predicts biodiversity loss' (2009) 23(5) Conservation Biology at 1304-1313. See also MA Andrich, J Imberger, \& ER Oxburgh 'Raising utility and lowering risk through adaptive sustainability: Society and wealth inequity in Western Australia' (2010) 3(3) Journal of Sustainable Development at 14-35; J Haupt \& C Lawrence 'Unexpected connections: Income inequality and environmental degradation' (2012) Shaping Tomorrow's World available at http:/ /www.shapingtomorrowsworld.org/hauptInequality.html (accessed 23 September 2018); J Elliott An introduction to sustainable development (2013).

48 Hayward (n 34) 60.

49 Norton (n 30) 138.

50 As above.

51 United Nations General Assembly World Charter for Nature UN Doc. A/RES/37/7, 28 October 1982, available at: http://www.un.org/documents/ga/res/37/a37r 007.htm. 
Fourth, that human self-love is not only natural but is helpful as a starting point for loving others, including nonhumans. ${ }^{52}$ Care for others starts with love for oneself. It logically follows from this, theoretically at least, that humanity can be at peace with itself, love itself more, and consequentially have a positive effect on other species. As Hayward states: 'positive concern for human well-being need not automatically preclude a concern for the well-being of nonhumans, and may even serve to promote it'. ${ }^{53}$

However, these arguments in favour of anthropocentrism can be countered in several ways. First, anthropocentric theorists provide fragmented definitions of anthropocentrism by stating that what is objected to under the heading of anthropocentrism in environmental ethics and ecological politics is a concern with human interests to the exclusion, or at the expense, of interests of other species. ${ }^{54}$ This is, in part, true, as reflected in in environmental ethics and animal rights literature. ${ }^{55}$ However, redefining the term anthropocentrism seems to be an attempt to ignore the behaviour in which humans focus on themselves at the risk of the planet. This is because it creates a new meaning of anthropocentrism, namely that of a legitimate concern for human welfare and fails to account for legitimate concerns for nonhuman welfare as it assumes that humans are the arbiters of what is 'legitimate'. Anthropocentric liberals fail to account for many things that matter or provide an ethic sufficient for addressing climate change such as, non-human individuals, other species, ecosystems and the biosphere. A deeper (ecocentric) environmental ethic recognises the welfare of all nonhuman forms. ${ }^{56} \mathrm{~A}$ holistic approach leads to the realisation that both biocentric and ecocentric values make the conservation of the species-variety of the planet (and its genetic diversity) of paramount importance. The lesson in ecology is that in the long run one must use 'systems thinking' to maintain holistic ecosystems. As long as the priority on defending planetary diversity is not lost, such an approach is compatible with 'compassionate conservation', where species and individuals within the species (and their habitats) are protected. ${ }^{57}$

52 Hayward (n 34) 52.

53 As above.

54 As above.

55 A Naess 'The shallow and the deep: Long-range ecology movement' (1973) $16 \mathrm{An}$ Interdisciplinary Journal of Philosophy at 95-100. See also WR Catton \& RE Dunlap 'Environmental sociology: A new paradigm' (1978) 13 American Sociologist at 41-49; E Katz 'Envisioning a de-anthropocentrised world: Critical comments on Anthony Weston's 'the incomplete eco-philosopher' (1999) 14 Ethics, Policy and Environment at 97-101; S Borras 'New transitions from human rights to the environment to the rights of nature' (2016) 5(1) Transnational Environmental Law at 113-143.

56 H Rolston III $A$ new environmental ethics: The next millennium for life on earth (2012) 60.

57 MP Nelson, JT Bruskotter, JA Vucetich, \& $\mathrm{G}$ Chapron 'Emotions and the ethics of consequence in conservation decisions: Lessons from Cecil the lion' (2016) 9(4) Conservation Letters at 304. 
In a similar way, it is important to be clear about the term anthropocentrism, which in its common meaning, is an ideology that is deep-rooted in the value in humanity. Although 'anthropocentrism' might be too imprecise a term to describe conditions that range from the destruction of the wilderness to the abuse of farm animals, we can hardly come up with the alternatively broad and meaningful term. There are of course subcategories of meaning that are markedly anthropocentric. The terms 'industrocentrism', 'human chauvinism' and 'species-ism' are key examples, though they are less known outside academic discourse. Although anthropocentrism has many meanings, at its core it involves the planetary-scale subordination of nonhuman organisms that denies they have value in their own right.

Furthermore, although there are some differences among various anthropocentric positions, there are also some commonalities that do not bode well for nonhuman well-being and biodiversity protection. Principal among these is the lack of ethical consideration for the intrinsic value of nonhuman forms. The commonly-held meaning of the term anthropocentrism is that 'only humans are worthy of ethical considerations' and 'other things are mere means to human ends'. ${ }^{58}$ Yet anthropocentrists change the meaning of the term to mean to care and be compassionate for people. Such erosion of meaning is problematic, because it confuses a formal description of the valuation theory with one legitimate aspect of that theory. Anthropocentrism (applied to humanity as a whole) should be retained as the term that describes a human-centred valuation theory, aspects of which are a powerful explanation for society's current environmental unsustainability and unethical treatment of nonhumans.

Second, anthropocentrists argue that humans differ greatly in their impact on the environment and consequently, addressing human inequalities should be a precondition for environmental protection. They have stated that 'a unified and peaceful body is more likely to be considerate - or at least guided by a far-sighted and ecologically enlightened conception of its self-interest - than one which is riven by internal strife'. ${ }^{59}$ Indeed, not all humans are equal in their impact, as 'there is tremendous diversity in relationships with and impacts on biodiversity'. ${ }^{60}$ This is certainly true, humanity is not harmonious and humans are unequal. But even if they were equal - the evidence of the positive relationship between equality and environmental protection is inconclusive at best. In other words, if addressing human inequalities is a precondition of environmental protection, biodiversity protection will remain out of the scope of ethical consideration for an indefinite period of time. In fact, there is (eds) Principles of conservation biology (2006) 119.

59 Hayward (n 33) 60.

60 Sponsel (n 41) 137. 
consensus among ethicists that the interests of at least some nonhumans are directly morally important. ${ }^{61}$ However, this has not been reflected at all in climate policy discussions, and it has mostly been ignored even within the climate ethics literature. The consensus on the human causes of global warming is almost unanimous within the scientific field, as at least $97 \%$ of actively publishing climate scientists agree that humans are responsible for recent trends in warming and greenhouse gas emissions, which are increasing due to human behaviour. ${ }^{62}$ This is driving up average global temperatures.

Thirdly, anthropocentrists advocate the convergence theory, which is that since ecosystems constitute the 'life-support system' for humans, anthropocentrism can and should be a powerful motivation for environmental protection. ${ }^{63}$ This however supports shallow ecology or protection of nature for human sake and is often associated with strong anthropocentrism or pragmatic environmental ethics. ${ }^{64}$ Pragmatic ethics is based on the assumption that anthropocentric or ecocentric motivations achieve the same ends, for example as in the case of fighting pollution threatening human health. ${ }^{65}$ Anthropocentrism writers state that, 'the best, if not only, reason for preserving eco-systemic relations is precisely that they constitute the 'life-support system' for humans'.66 However, while an anthropocentric motivation can produce environmentally-positive outcomes in situations where both humans and environment are negatively affected, anthropocentrism does not protect nonhumans without utilitarian value, nor safeguard animal welfare. ${ }^{67}$ In fact, the loss of some biodiversity does not affect humanity (at least not yet), as evidenced by mass extinctions. ${ }^{68}$ Moreover, we know the long-term effect of disappearance of keystone species necessary for our survival-however, what keystone species should be saved is in fact unknown and is likely to remain so. ${ }^{69}$ What allows pragmatic ethicists to rehabilitate anthropocentrism, as a basis of an environmental

61 Hayward (n 33).

62 NASA, (2016). Global climate change, evidence. Retrieved from website: http: / / climate.nasa.gov/evidence. See also The Intergovernmental Panel on Climate Change (IPCC) 'Climate Change, the IPCC Scientific Assessment' (1990) available at https://www.ipcc.ch/publications_and_data/publications_ipcc_frst_assess ment_1990_wg1.shtml; IPCC 'Climate Change 2014 - 5th Assessment Report' available at http://www.ipcc.ch/pdf/assessment-report/ar5/syr/SYR_AR5_ FINAL_full.pdf; TM Lenton 'Early warning of climate tipping points' (2011) 1(4) Nature climate change at 204.

63 Weston (n 30) at 329.

64 Naess (n 55) 96.

65 Norton (n 30) at 139. See also Grey (n 30) at 470; Weston (n 30) at 330.

66 Hayward (n 33) at 60.

67 P Singer Animal liberation: A new ethics for our treatment of animals (1977) 200. See also Katz (n 55) at 97-101.

68 E Crist 'I walk in the world to love it' in G Wuerthner, E Crist, \& T Butler (eds) Protecting the wild: Parks and wilderness, the foundation for conservation (2015) 82-95.

$69 \mathrm{H}$ Washington Human dependence on nature: How to help solve the environmental crisis (2013) 78. 
ethic, is their own rejection of the intrinsic value of nature. ${ }^{70}$ By rejecting this intrinsic value, environmental protection is enacted only to the extent needed for human well-being, and a human environmental right subjugates all other needs, interests and values of nature to those of humanity. ${ }^{71}$ Thus, non-anthropocentrism/ ecocentrism is necessary to counter the accelerating threats to environmental elements that do not directly contribute to human welfare. $^{72}$ Anthropocentric motivation is not enough as I hereby illustrate. For example, the World Charter for Nature of the United Nations General Assembly (1982) calls for non-wasteful use of natural resources and observes that humanity benefits from healthy ecological processes and biological diversity. However, this is essentially still an anthropocentric position that sees nature as a resource, where protection extends only to the 'critical natural capital' needed for society - not the rest of nature. ${ }^{73}$ This argument, in fact, is at the root of the concept of ecosystem services, which has now become a dominant paradigm in ecology and conservation literature, and a driving force for governmental and NGO conservation. ${ }^{74}$ The ecosystem services approach however remains anthropocentric, as it focuses on only benefits for people. ${ }^{75}$

The World Charter for Nature of the Untied Nations General Assembly (1982) also states that every form of life warrants respect 'regardless of its worth to man', and as a result, such respect requires us to be 'guided by a moral code of action'. ${ }^{66}$ This moral code of action is not likely to be instructed by the same thinking that produced anthropocentrism as a dominant ideology in the first place. To recall the famous quote by Albert Einstein: 'we cannot solve our problems with the same thinking we used when we created them'. Anthropocentrism does not allow for the possibility of radical change similar to that which ended slavery, and led to rights for women and

70 Katz ( $n$ 56) 99. See also F Mathews 'From biodiversity-based conservation to an ethic of bio-proportionality' (2016) 200 Biological Conservation at 140-148; RF Noss 'The wildlands project land conservation strategy' (1992) 1 Wild Earth at 9-25.

71 L Bisgould 'Power and irony: One tortured cat and many twisted angles to our moral schizophrenia about animals' (2008) 8 Animal subjects: An ethical reader in a posthuman world at 259. See also Borras (n 56) 113-143.

72 F Quinn, J Castera \& P Clement 'Teachers conceptions of the environment: Anthropocentrism, non-anthropocentrism, anthropomorphism and the place of nature' (2016) 22(6) Environmental Education Research at 893-917.

73 P Ekins and others 'A framework for the practical application of the concepts of critical natural capital and strong sustainability' (2003) 44(2) Ecological Economics at 170.

74 Millennium Ecosystem Assessment 'Ecosystems and human well-being: Biodiversity Synthesis' (2005) available at http://www.millennium assessment. org/en/index.html (accessed 18 September 2018).

75 Norton (n 30) at 141-148. See also $H$ Washington Demystifying sustainability: Towards real solutions (2015).

$76 \mathrm{~K}$ Sykes 'Globalization and the animal turn: How international trade law contributes to global norms of animal protection' (2016) 5 Transnational Environmental Law at 55-79. 
ethnic minorities. While the most promising hope for maintaining significant biodiversity under our prevailing value system has been said to be ecologically-enlightened self-interest, it holds no ground if there are risks, and also when exclusive self-interest promises a 'bigger pay off' ${ }^{77}$ As Washington argues, if instead we were to shift to ecocentric values, nature's survival would be ensured even more effectively, along with the ecosystem services humanity depends on. 78

Fourth, anthropocentrists have argued that human self-love is not only natural but helpful as a starting point for loving others, including nonhumans. However, 'self-love' alone is an inadequate basis for environmental concern and action. In fact, we should be cautious to assume that self-love can be considered a precondition of loving others as sometimes in consumer-oriented and often narcissistic societies, self-love often happens to be the goal in and of itself. ${ }^{79}$ Besides, even if ideally humanity can be at peace with itself and be harmonious, this does not mean that it will be collectively biophilic some people will be, some not. ${ }^{80}$ While some cultures respect (holy) cows or worship trees, other communities can be cruel to animals and indifferent to these worldly environmental concerns. ${ }^{81}$ Learning to 'love' or respect one's own tribe does not mean loving animals (or sacred forests and places). Even though some individuals might 'love' animals, there is an increasing proportional difference between the number of people on this earth and the number of nonhumans outside of food and medical industries. 'Self-love' cannot address how the food and medical industries have evolved to serve us at the expense of billions of other species without the protection of law.

In all, anthropocentrism is clearly a significant driver of ecocide, climate change and the environmental crisis, for society has been madly pursuing project 'human planet' without considering that humanity is (in the end) fully dependent on nature. Anthropocentrism cannot lead us to a sustainable future. Ecocentrism, in contrast, accepts that we are part of nature, and have a responsibility to respect the web of life and heal the damage caused by the ideological dominance of anthropocentrism.

77 W Rees 'Toward sustainability with justice: Are human nature and history on side?' in C Soskolne (ed), Sustaining life on earth: Environmental and human health through global governance (2008) 89.

78 Washington (n 69) at 63.

79 D Carnegie How to stop worrying and start living (2004) at 73.

$80 \mathrm{H}$ Kopnina 'Revisiting the Lorax complex: Deep ecology and biophilia in crosscultural perspective' (2015) 43(4) Environmental Sociology at 320. See also B Taylor Dark green religion: Nature spirituality and the planetary future (2010)

81 Taylor (n 80) at 66. See also B Taylor 'It's not all about us: Reflections on the state of American environmental history' (2013) 100(1) Journal of American History at 140-144; B Taylor and others 'The greening of religion hypothesis (part two): Assessing the data from Lynn White, Jr., to Pope Francis' (2016) 10(3) Journal for the Study of Religion, Nature \& Culture 306-378; Sponsel (n 41) 137. 


\subsection{Role of Government}

Most times, suits on climate violation are against the government. This is against the backdrop that there is an obvious duty on the State to protect its people. ${ }^{82}$ The government can effectively make policies for adequate resilience and combat injustice. The government can integrate climate change measures into national policies and strategies; plan and promote mechanisms for raising capacity for effective climate change-related planning and management, including focusing on women, youth and marginalised communities; and strengthen resilience and adaptive capacity to climate-related hazards and natural disasters in all countries. The government can build on existing development and human rights agreements, set up actions to slow climate change, back investment approaches to climate change in order to facilitate climate resilience and environmental justice. Administrative policies should be taken to cover protective and preventive measures so as to reduce potential harm in case of natural disasters and catastrophic accidents. Also, in view of the security interest of its citizens, a high level of meticulousness should be required of the state in matters of the environment which affect the climate. ${ }^{83}$

The government has to help in improving our knowledge. Easy access to information about climate change and technical adaptation measures should be facilitated by the government. Without government intervention, too little information would be generated. Moreover, financing basic research in this area is one of the fundamental tasks for a central government. ${ }^{84}$

Also, the government has to provide the regulatory framework for insurance markets. The economic consequences of natural disasters can be cushioned through insurance markets. However, the incentives to buy insurance are often insufficient for several reasons. If the government wants to avoid being pressured for disaster relief, it has to make disaster insurance mandatory. Furthermore, in order to induce citizens to the appropriate amount of self-protection,

82 UN General Assembly Resolution 53/144 (1998), 'Declaration on the Right and Responsibility of Individuals, Groups and Organs of Society to Promote and Protect Universally Recognised Human Rights and Fundamental Freedoms'. See also Social and Economic Rights Action Centre (SERAC) and Another v Nigeria (2001) AHRLR 60 (ACHPR 2001) paras 44-47; IHRDA and Open Society Justice Initiative (OSJI) (on behalf of children of Nubian descent in Kenya) $v$ Kenya [Communication 2/09 (2011)] para 58.

83 KJ de Graaf and JH Jans, 'The Urgenda Decision: Netherlands liable for role in causing dangerous global climate change' (2015) 27 Journal of Environmental Law at 522.

84 Kai Konrad and Marcel Thum, 'What is the role of governments in climate change adaptation?’ available at https://blog.oup.com/2014/07/governmentadaptationclimate-change/ (accessed 20 September, 2018). 
insurance premiums have to be differentiated according to local disaster risks. 85

Particularly affecting climate justice, and resilience, the following are policies, strategies and legal actions that the government can act on;

\subsubsection{Looking beyond the State: A cosmopolitan perspective on climate justice}

There is the need to find a 'fair' burden-sharing formula. In doing this, the cosmopolitan perspective is suggested. It shows that the real divide is not only between developed and developing states, but also between affluent and poor people. By taking into account not only international but also intra-national equity considerations, it becomes possible to move beyond the simplistic developeddeveloping country dichotomy and to reassess justice among states in the context of the practical realities of climate change. In line with the cosmopolitan perspective, private affluence is thought to be an underlying cause of environmental destruction and a source of financing for public investments in technologies that are necessary to tackle climate change effectively. Summarily, in order to get robust mitigation efforts off the ground, it is essential that the high-carbon lifestyles of the global middle class are regulated and taxed, as well as those of the most affluent people. ${ }^{86}$ Regulating or/taxing high carbon lifestyles must be part of robust mitigation efforts, unless there are very significant and rapid technological breakthroughs. The global costs of adaptation to climate change should be shared, not between states but between the world's wealthy (i.e. those capable of contributing) and the poor (i.e. those most heavily affected but least able to contribute). According to this logic, while the state has an important role as an 'intermediary', funds would essentially flow from the capable to the vulnerable across borders. A cosmopolitan perspective has the potential to offer fairer benefit and burden sharing.

\subsubsection{Legal obligations to combat climate change}

Furthermore, on climate justice, honing in at the state level can nonetheless enhance climate justice by urging states to fulfil their legal obligations with regard to curtailing climate change emissions. There are foundations in existing law that are applicable to climate policy, as highlighted by the Oslo Principles. ${ }^{87}$ According to the

85 As above.

86 PG Harris, A Chow, and R Karlsson, 'China and climate justice: Moving beyond statism', International environmental agreements (2013) 13 \& 301. 
working group, there are many legal methods to force a country to reduce greenhouse gas emissions. Judges may, on the basis of international law, human rights and liability judge what a state must do to prevent the harmful effects of climate change. The centrepiece of the Oslo Principles is the Precautionary Principle, which requires that:

(a) GHG emissions be reduced to the extent and at a pace necessary to protect against the threats of climate change that can still be avoided; and

(b) The level of reductions of GHG emissions required to achieve this, should be based on any credible and realistic worst-case scenario accepted by a substantial number of eminent climate change experts. ${ }^{88}$

The measures required by the Precautionary Principle should be adopted without regard to the cost, unless that cost is completely disproportionate to the reduction in emissions that will be brought about by expending it. By defining the scope of legal obligations relevant to climate change, the Oslo Principles may provide some opinio juris that help judges decide whether governments are complying with their legal obligations to address climate change. The Oslo Principles can be seen both as an awareness raising instrument and as a guide for judges to urge compliance by the state with their existing legal obligations, which can be invoked by civil society to hold their governments accountable when they are not doing enough to mitigate climate change. This approach enhances democratisation through active citizen participation and the claim for transparency and accountability. Thus, a positive side-effect of such responses to climate change is the creation of new ways of governance seeking justice based on good governance principles.

\subsubsection{Climate change as a form of ecocide and a crime against peace}

In addition, due to the irreversible global (environmental) changes that climate change is causing, with its impact extending to future generations, (future) peaceful enjoyment of the damaged environment becomes substantially diminished. Climate change could be considered a form of ecocide occurring on a global scale, with ecocide also recognised as a crime against peace in international and

87 The Oslo Principles on Global Climate Change Obligations (2015). The Oslo Principles were adopted on March 1, 2015, by a group of experts in international, environmental, tort, and human rights law. The working group included thirteen lawyers and scientists from nine countries, including judges of the Supreme Court of Brazil, the Netherlands, India, Australia and the European Court of Human Rights. The Oslo Principles both define the scope of states' legal obligations to protect the environment and outline a means of meeting these obligations. http: / /globaljustice.macmillan.yale.edu/sites/default/files/files/OsloPrinciples.pdf. Principle 1 of the Oslo Principles on Global Climate Change Obligations (2015). 
domestic law. ${ }^{89}$ Today, there is no international law against criminal mass damage and destruction of ecosystems and animals, especially during peacetime. Hence, the principle nulla poena sine lege will almost always apply and hence, to date no single party, internationally, has been convicted of the environmental war crime. ${ }^{90}$ To this end, climate justice can also be extended to the realm of retributive justice. Ecocide describes the significant damage to or destruction of an ecosystem to such an extent that peaceful enjoyment of a part of that environment will be substantially diminished. A growing body of scientific evidence suggests that the earth has reached a 'tipping point'91 and we are approaching 'planetary boundaries'. ${ }^{22}$ A range of immediate and effective mechanisms is needed to safeguard the rights of future generations. However, the rights of nature itself against ecocide also need to be viciously guarded. One step forward could be the creation of the crime of ecocide as a fifth crime against peace.

A research paper by the Human Rights Consortium at the School of Advanced Studies, University of London, has shown that the UN has discussed such a crime for decades, especially throughout the 1970s - 1990s. ${ }^{93}$ The term became known after World War II, in particular, the Vietnam War. ${ }^{94}$ Even though ecocide was eventually shelved last minute in 1996, several countries implemented it in their national legislation, such as Vietnam, the Russian Federation, and other former Soviet countries. ${ }^{95}$ While awaiting international recognition, these issues are being played out in domestic claims. Several states have started to recognise the rights of nature, ecosystems and animals and there has been an increasing recognition of the intersection between human rights and environmental degradation. ${ }^{96}$ In 2010, Bolivia adopted the Law of the Rights of Mother Earth, while Ecuador dedicated an entire chapter of its 2008 constitution to the

89 A Greene 'The campaign to make ecocide an international crime: Quixotic quest or moral imperative?' (2019) 30(3) Fordham Environmental Law Review at 1-2.

90 This means there is no penalty without law.

91 University of California - Berkley, 'Evidence of impending tipping point for earth', Science Daily, (June 2012), available at: http://www.sciencedaily.com/ releases/2012/06/120606132308.htm (accessed 18 September 2018).

92 Stockholm Resilience Centre, 'Planetary boundaries: Guiding human development on a changing planet', (January 2015). Available at: http://science.science mag.org/content/early/2015/01/14/science.1259855 (accessed 18 September 2018).

93 A Gauger and others, Ecocide is the missing 5th crime against peace, Human Rights Consortium, School of Advanced Study, University of London, (2012).

94 RA Falk, Environmental warfare and ecocide - facts, appraisal and proposals, 4Security Dialogue, Princeton University (1973) 80-96.

95 Armenia, the Republic of Moldova, Georgia, Belarus, Ukraine, Kazakhstan, Kyrgyzstan, Tajikistan. See also art 358 of the Criminal Code of the Russian Federation; art 342 of the Vietnam Penal Code.

96 From the right to self-determination, right to economic and social development, right to natural resources, right to communicate to the right to food, right to life, health and human dignity. 
Rights of Mother Earth. ${ }^{97}$ Significantly, several court judgements afford protection to the ecosystems and animals. Countries such as Kenya, South Africa, Uganda and Benin have recognised the sanctity of certain natural sites belonging to indigenous communities. Dolphins have recently been recognised to possess 'personhood' in India. ${ }^{98}$ Belize ruled in the 2009 Westerhaven $v$ Belize case that, 'it is really more accurate to describe and refer to the damage to the Barrier Reef as 'injury' because the reef is a living organism'. 99 In 2008, the Criminal Court of Paris convicted, for the first time, a company for environmental damage. ${ }^{100}$ More recently, in July 2015, Guatemala became the first country to establish a court dedicated to adjudicating the crime of ecocide. In its first case, the Environmental Crimes Court ruled against a palm oil corporation, an industry associated with a litany of human rights and environmental abuses in the country. An appellate court upheld the decision. ${ }^{101}$

Hence, this approach can be adopted by other countries in a bid to pursue climate justice for both citizens and the environment. Ecocide aims to underline the urgent necessity to establish respect for future generations, a principle that was referenced already in several declarations. ${ }^{102}$ While recognising climate change as a form of ecocide, establishing a new norm that prohibits ecocide might not prevent damage to the environment, it could nonetheless send a strong message concerning the obligation upon States, corporations and individuals to protect it. Hence, the official inclusion of ecocide prevention as an international norm can help advance climate justice by, at a minimum, signalling to states, corporations and individuals that they have obligations to mitigate climate change and at a maximum, provide a new mechanism for safeguarding rights violated due to a lack of action to address climate change.

97 Bolivia Ley de Derechos de la Madres Tierra (2010) 1-2.

98 Policy on Establishment of Dolphinarium-Regarding, Circular F.NO, 20-1/2010-CZA (M)/2840 Government of India - Ministry of Environment and Forests (2010), available at http://cza.nic.in/ban on dolphanariums.pdf.

99 Attorney-General of Belize v MS Westerhaven Schiffahrts, Claim No 45 of 2009 (4.26.2010) 37 para 89. Available at http://files.harmonywithnatureun.org/ uploads/upload698.pdf.

100 https://www.nytimes.com/2010/03/31/business/energy-environment/31total. html (accessed 18 September 2018).

101 C Parker, 'Justice in Guatemala: Guatemalan Court upholds revolutionary ruling on ecocide', IC Magazine (January 2016), https://intercontinentalcry.org/justicein-guatemala-guatemalan-courtupholds-revolutionary-ruling-on-ecocide/ available at (accessed 18 September 2018).

102 Principle 1 of the United Nations Stockholm Declaration on the Human Environment, adopted in June 1972, UN Doc A/Conf.18/14/Rev 1(1973). See also Principle 3 of the United Nations Rio Declaration on Environment and Development UN Doc. A/CONF.151/26 (vol I); 31 ILM 874 (1992); United Nations Educational, Scientific and Cultural Organisation (UNESCO) 'Declaration on the Responsibilities of the Present Generations Towards Future Generations' 12 November 1997 Specific reference in terms of article or principle?. 


\subsubsection{Multi-level and multi-stakeholder climate governance to advance climate justice}

To be effective, climate governance needs to include the macro level (intergovernmental and international), the meso level (regional, national, and subnational), and the micro level (municipal, local, and community). It also and especially needs to be non-territorial (corporate, industrial, transnational, and transboundary).

Multilevel governance is needed to create the necessary linkages, by means of participation and deliberation as informed by context, in order to incorporate political and public support, and verify and accredit activities on the ground. This in turn entails fine-tuning bottom-up learning processes with top-down policy strategies and visions.

It is clear that a 'one-size-fits-all' approach for mitigation or adaptation is not appropriate for the complexities of climate change. Strategies should stimulate and support pro-active mitigation and adaptation responses, whilst retaining the flexibility and robustness necessary for enabling the development, testing and implementation of measures at the local scale. The complexities inherent in climate change pose a major challenge for strategic policy communities, since integration needs to occur horizontally across different sectors and policy areas, as well as vertical integration across levels. This ultimately will require the consideration of mitigation or adaptation through existing institutional mechanisms, a process commonly known as 'mainstreaming'. In consequence, this means that local authorities have to adapt their spatial planning, housing, farming, water management, public health and business policies to the environmental and climatic changes. Resettlements and reallocation of people is one of the most applicable adaptation policies which communities and governments have to deal with.

\subsubsection{Outlining a rights-based approach to climate change}

Unequivocally, climate change will have a profound effect on the enjoyment of human rights for billions of people. It is already contributing to food shortages, drought and ecosystem degradation across the entire planet. ${ }^{103}$ Reports of the UNFCCC, UNDP, Human Rights Council, as well as of certain scholars, have shown clearly that the detrimental effects of climate change fall particularly heavily upon more vulnerable sectors of society owing to geography, poverty,

103 Oxfam Entering uncharted waters: El Nino and the threat to food security (2015) 3-4. Available at https://www-cdn.oxfam.org/s3fs-public/file_attach ments/mbel-nino-uncharted-waters_1.pdf. 
cultural and ethnic backgrounds, gender, age or disability. ${ }^{104}$ Furthermore, some regions are hit harder than others.

The concept of 'climate justice' is a perspective that recommends the alignment of climate change prevention, mitigation and adaptation strategies with sustainable development policies that incorporate a human rights-based approach. Essentially, the human rights-based approach implies that challenges and solutions must take full account of; the human rights of individuals and groups affected by climate change, the measures to reduce climate change, and the appropriate adaptation strategies. It aims to ensure that human rights are accorded prime consideration among the wide array of social, political, economic, and security priorities that face Governments and the international community. ${ }^{105}$ In view of this, conservation policies should not be enacted in a way that restricts access to everyone's right to clean and affordable food and water. More broadly, all climate change related international agenda setting and national policy action should ensure the maximum promotion and protection of the human rights of all on a non-discriminatory basis. In this sense, it is essential to identify clearly which and whose human rights are affected, when, where and how. It is crucial to determine the corresponding legal obligations incumbent upon governments, corporations and other key entities to respect such rights when it comes to climate justice issues, as this is the element which lies at the heart of the human rights-based approach. ${ }^{106}$

This implies that policy setting and implementation at all levels should be guided by the basic minimum human rights standards. These are set out in the Universal Declaration of Human Rights (UDHR), as well as by the main multilateral UN human rights treaties. ${ }^{107}$ Also, the Vienna Declaration and Programme of Action, the Declaration on the

104 UNFCCC Paris Climate Change Agreement, available at http://newsroom. unfccc.int/unfccc-newsroom/historic-paris-agreement-available-in-all-six-un-lan guages/ (accessed 17 September 2018); UNDP Report, 'UNDP and Climate Change - Zero Carbon, Sustainable Development', (November 2015); UN Human Rights Council Summary report on the outcome of the full-day discussion on specific themes relating to human rights and climate change, held on 6 March 2015 during the 28th session of the Council; Policy Report by Jane McAdam and Marc Limon, 'Human Rights, Climate Change and Cross Border Displacement: the Role of the International Human Rights Community in Contributing to Effective and Just Solutions' (2015).

105 The OHCHR Report on the Relationship between Climate Change and Human Rights, A/HRC/10/61, (January 2009), available at https://documents-ddsny.un.org/doc/UNDOC/GEN/G09/103/44/PDF/G0910344.pdf?OpenElement.

106 UNEP, in cooperation with Columbia Law School, Sabin Center for Climate Change Law, Climate Change and Human Rights, 15 (December 2015) at 11, 13 \& 26, available at https://web.law.columbia.edu/sites/default/files/microsites/cli mate-change/climate_change_and_human_rights.pdf.

107 For example, The International Covenant on Economic, Social and Cultural Rights (ICESCR), the International Covenant on Civil and Political Rights (ICCPR), the Convention on the Rights of the Child (CRC) or the International Labour Organisation (ILO) Convention No. 169 concerning Indigenous and Tribal Peoples. 
Right to Development, the 2030 Agenda for Sustainable Development, the UN Common Understanding of a Human Rights-Based Approach to Development Cooperation, as well as certain other resolutions and laws at both regional and national level, offer considerable guidance on how to develop climate change policy in a fair and equitable manner, in short, to produce 'climate justice'. ${ }^{108}$

The interconnectedness and interdependence among all human rights, the principles of non-discrimination and equality, democratic accountability, rule of law and political inclusiveness of all stakeholders in policy making and on climate change issues, remain basic and uncontroversial standards. Putting these and other related principles into practice, however, poses concrete challenges in terms of actual implementation. ${ }^{109}$ These principles remind policy makers that civil and political rights cannot be accorded priority over the economic, social and cultural rights, or the other way around. Practically speaking, the principles of the rule of law, participation, inclusion and access to information, require that law and policy processes, as well as the adjudication of disputes, be done according to the law rather than in an arbitrary manner. In this context, all affected communities, must be genuinely, thoroughly and diligently consulted on the decisions which are likely to affect them with regard to climate-related issues. It requires that those who are unavoidably disadvantaged from climate policy decisions be adequately compensated for their loss, that the disadvantage itself be minimised and that everyone has recourse to challenge the law and policy in climate related matters, so that injustices can be fairly redressed. ${ }^{110}$

In short, climate justice has to adopt a consistent human rightsbased approach for the following reasons:

- First, the effects of climate change and the measures to prevent, reduce or mitigate these effects, together with climate change adaptation strategies, inevitably affect the human rights of individuals and groups. In order to fully recognize the human rights implications of climate change issues, a human rights-based approach therefore has to be taken. An approach that accurately identifies which and whose human rights are affected and how they are

108 Resolutions such as UN Human Rights Council Resolution 7/23 (2008) that acknowledged the threat of climate change (March 2008). See also UN General Assembly Resolution 64/292 (2010) that explicitly recognised the human right to water and sanitation and acknowledged that clean drinking water and sanitation are essential to the realisation of all human rights (2010).

109 Report by the Food and Agriculture Organization of the United Nations and Earthscan, 'The state of the world's land and water resources for food and agriculture - managing systems at risk', (2011).

110 M Silina European Environmental Bureau \& European ECO Forum, is everything right with public participation in climate related decisions?, Presentation for the Fifth Meeting of the Task Force on Public Participation in Decision-making, Geneva, February 23-24 (2015). 
affected; as well as the kinds of approaches that should be taken to provide redress to those persons;

- Second, climate justice can be achieved only if the human rights guaranteed in all universal human rights standards and norms, of everyone affected in any way by climate change, are fully respected;

- Third, where legal disputes arise in relation to climate change issues, the courts and any other dispute resolution mechanisms, must adjudicate the matter in line with international human rights law.

\subsection{Role of civil society and individuals}

Civil society groups have been empowered to champion courses of climate change in some countries. For instance, the European Union law confers many rights on individuals and non-governmental organisations (NGOs) in order to equip them to act as environmental watchdogs. ${ }^{111}$ Moreover, as a part of global collective action, greater emphasis should be given to the role of diverse coalitions that are already emerging at the community, local, city, corporate and country levels and the vital role they play in mobilising actions. Some of these coalitions are already championing the solutions needed to solve the crisis and their effect can be maximised by supporting them to connect and scale up for greater impact. ${ }^{112}$

Advocacy on behalf of the climate is ultimately advocacy on behalf of the billions of people whose lives depend on a healthy planet. The global climate is interconnected, both environmentally and socially. Fixing an interconnected world demands interconnected movement; anyone who believes that all individuals deserve basic human and civil rights should see the climate crisis as an imminent threat. The issue of climate resilience and climate justice apparently involves all hands to be on deck, if not, the threats climate change portends will persist. In the same vein, social or institutional assets within a determined society are needed. Partnership with other civil society groups and the government could be of immense help to facilitate climate resilience and fight for climate justice. ${ }^{113}$

The role of civil society groups can be further outlined below:

(i) Accelerating Climate Action: Civil society groups should encourage decision-makers to explicitly adopt the precautionary principle

111 A Ryall 'Access to environmental information in Ireland: Implementation challenges' (2011) 23(1) Journal of Environmental Law at 45.

112 As above.

113 For instance, Partnership for the Development of Environmental Law in Africa (PADELIA). Its overall vision is to enhance the capacity of African countries in building capacity for development, implementation and enforcement of environmental laws and to strengthen environmental institutions for sustainable development and poverty reduction. It seeks to assist African governments in building capacities for developing, strengthening, implementing and harmonising their environmental legislation. 
when planning new projects that might have a large environmental or social impact. The precautionary principle is defined as a principle undertaken when an activity raises threats of harm to human health or the environment and precautionary measures are taken even if some cause-and-effect relationships are not fully established scientifically. ${ }^{114}$ Also, civil society groups can develop small-scale integrated river-basin projects that help promote climate resilience by helping vulnerable groups prepare for, withstand and recover from the negative effects of climate change. ${ }^{115}$

(ii) Enhancing Transparency and Accountability: Decision-making processes should follow widely accepted principles of good governance, chiefly: transparency, accountability, timeliness, and responsiveness. Groups can urge the government to recognise that the community groups that are most affected have a legitimate claim for being involved in decision-making processes and ensure that dispute resolution processes are accessible and fair in order to attain climate justice and good governance in society. ${ }^{116}$

(iii) Integrating Human Rights into Climate Actions: Civil society groups can submit parallel reports on human rights and climate change to the appropriate authorities. They can also build coalitions with local groups to document and report human rights issues at the national level and bring them to the attention of international human rights mechanisms. ${ }^{117}$ Furthermore, they can monitor, lobby, and support governments, businesses and other actors in the implementation of climate commitments. Moreover, they can raise awareness of climate change and its human rights impact and build capacity at the state and national level; bring appropriate actions before human rights mechanisms and courts to flesh out State and business obligations related to climate change because sometimes the victims of the climate injustice may not have the opportunity to table their complaints to the appropriate authorities.

(iv) Improved Public Access to Climate Information: Organised civil society groups can, in their capacities, provide adequate information concerning climatic situations. Civil society groups could act as a tunnel between research institutes and the population, leading to a more direct dialogue. Information could as

114 'Climate Resilience' available at https://en.wikipedia.org/wiki/Climate_ resilience (accessed 17 September 2018).

115 As above.

116 As above.

117 'Summary of Recommended Actions on Human Rights and Climate Change from OHCHR Expert Meeting' of 6 - 7 October'. Available at https://www. google.com/ url?sa=t\&rct $=j \notin q=\&$ esrc $=$ s\&source $=$ web\&cd $=1 \&$ ved $=0$ ahUKEWigOfnMP7WAhWDYVA KHUmcAmEQFgglMAA\&url=http\%3A\%2F\%2Fwww.ohchr.org\%2FDocuments\%2Flssues \%2FClimateChange\%2FEM2016\%2FSummaryRecommendations.docx\&usg=AOvVaw1 Fikbp5brRmHJOK84TC95 (accessed 19 September 2018). 
well come through education of the masses about their rights to climate justice. ${ }^{118}$

\subsection{Role of the legal community: Case law discussion}

Courts provide a public forum for persons who are affected by climate change to have their concerns and claims heard and determined. Any person with a justiciable claim is entitled to bring proceedings in a court of competent jurisdiction and have it heard and determined. This accessibility is a hallmark of the judicial branch of government. ${ }^{119}$ Thus, there are a number of cases which the courts have successfully handled with regard to climate change. These are landmark cases that prove that the legal community has a fundamental role to play in ensuring climate resilient measures and climate justice.

In Urgenda Foundation $v$ The Netherlands, the Hague District Court found that the Netherlands must do more to avert the imminent danger posed by climate change in view of its duty of care to protect and improve the living environment. ${ }^{120}$ In addressing the fact that Dutch contribution to global climate emissions is $0.5 \%$, the Court said that any anthropogenic greenhouse gas emission, no matter how minor, contributes to an increase in carbon dioxide levels in the atmosphere and therefore, to hazardous climate change.

In addition, the Court found a sufficient causal link 'can be assumed to exist' between Dutch emissions, global climate change, and the effects. The Court determined the Dutch government must reduce carbon dioxide emissions by a minimum of 25\% (compared to 1990) by 2020 to fulfil its obligation to protect and improve the living environment against the imminent danger caused by climate change. ${ }^{121}$

In Julian v United States, 21 youth plaintiffs and Dr Hansen sued the federal government of the United States for allowing and encouraging increasing carbon emissions over the past 50 years, despite knowing about global climate change. ${ }^{122}$ The plaintiffs claim

118 Art 3(4) of European Union Directive 90/313 on the Freedom of Access to Information on the Environment $(\mathrm{OJ} L 154,56)$ provides that a public authority is to respond to a person requesting information as soon as possible and at the latest within two months and that the reason for a refusal to provide the information requested must be given. See also V Edwards 'European Court of Justice - significant environmental cases 2005' (2006) 18 Journal of Environmental Law at 163.

119 B Preston 'The contribution of the courts in tackling climate change' (2016) 28 Journal of Environmental Law at 11-17.

$120 \mathrm{C} / 09 / 456689 / \mathrm{HA}$ ZA 13-1396 (24 June, 2015) Hague District Court, available at: https://elaw.org/system/files/urgenda_0.pdf (accessed 12 September 2018).

121 Case summary available at https://elaw.org/nl.urgenda.15 (accessed 12 September 2018).

122 Case No 6:15-cv-01517, filed 11/10/2016. 
the federal government violated their constitutional due process and public trust rights and demanded that the government design and implement a plan to slash carbon emissions. The district court of Oregon held that there is a constitutional right to a safe climate for the youth of America and the world.

Gbemre $v$ Shell Petroleum Development Company of Nigeria was an instance where an individual and community in the Niger Delta of Nigeria, filed a suit in the Federal High Court of Nigeria against Shell and other major oil companies to stop gas flaring. ${ }^{123}$ Gas flaring in Nigeria has contributed more greenhouse gas emissions than all other sources in sub-Saharan Africa combined, as well as poisoning local communities. The court held that the gas flaring was a gross violation of constitutionally guaranteed rights to life and dignity. This was the first time that a Nigerian court applied the rights to life and dignity in an environmental case. ${ }^{124}$

Petition to the Inter American Commission on Human Rights Seeking Relief from Violations Resulting from Global Warming Caused by Acts and Omissions of the United States: The Arctic Inuit, filed a petition arguing that the impact of climate change in the Arctic infringes upon the environmental, subsistence, and other human rights of Inuit. ${ }^{125}$ The Inuit sought a ruling from the Commission that the US must adopt mandatory limits on greenhouse gases and '... help the Inuit adapt to unavoidable impacts of climate change.' The Inuit relied on the breach of the following rights set out in the American Declaration of Rights and Duties of Man: the right to life (Art. 1), the right to residence and movement (Art. VIII), the right to inviolability of the home (Art. IX), the right to preservation of health and to wellbeing (Art. XI), the rights to benefits of culture (Art. XIII) and the right to work and to fair remuneration (Art. XIV). The Commission technically dismissed the Petition in December 2006. A hearing was however held in March 2007. No hearing report appears to have been published. ${ }^{126}$

These decisions have inspired environmental lawyers in the same and several other countries to see if they have opportunities in their domestic courts to pursue similar litigation. The legal community should become much more active in the fight against the overwhelming problem of climate change. Though it remains unclear

123 (2005) AHRLR 151 (NgHC 2005).

124 Climate Justice Programme, 'Human rights' available at http://climate justice.org.au/issue/human-rights/ (accessed 20 September 2018).

125 Petition to the Inter American Commission on Human Rights Seeking Relief From Violations Resulting From Global Warming Caused by Acts and Omissions of the United States, December 7, 2005, available at: http://blogs2.law.columbia.edu/ climate-change-litigation/wp-content/uploads/sites/16/non-us-case-documents/ 2005/20051208_na_petition.pdf (accessed 10 October 2019).

126 As above. 
how the courts can enforce its ruling, it should still initiate a change and hopefully the other branches of government will follow suit. ${ }^{127}$

Moreover, because court cases are often costly, cumbersome, technical and time consuming, the legal professionals can effectively use Alternative Dispute Resolution to serve as an essential function in the attainment of justice, especially where loss and damage is involved. Conciliation and mediation have both been known for many years in practically every community as methods of settling disputes by consensus rather than by adjudication.

Creation of environmental dispute resolution mechanisms to facilitate climate justice would be invaluable. The mechanism may include conciliation, mediation and even arbitration. In conciliation, climate infringement disputes may be settled between the disputing parties through consultation and negotiation. Conciliation is considered because it is probably a most speedy, flexible, inexpensive and efficient way of resolving environmental disputes, if the two parties are willing to reach a compromise. However, there is a high moral risk involved in conciliation due to the lack of an external binding force between the parties. ${ }^{128}$

In addition, provision of pro bono services for climate justice could be of great benefit to society. Most victims of climate injustice are farmers, peasants, fishermen, rural dwellers; they may not have the financial wherewithal to undertake legal actions against climate injustice perpetrators such as, multinational companies. Therefore, pro bono services could be a bedrock of advocacy for vulnerable groups and individuals in society by the legal community.

Furthermore, building capacity to undertake legal reforms is apt for both climate resilience and climate justice, although, legal reforms require appropriate institutional, technological, financial and human capacities. Capacity building refers to strengthening skills, competencies and abilities of people, as well as improving technological support to the reform process. These measures are often complementary instruments to legal reform and often attract international financing support. ${ }^{129}$

127 I Quimosing \& E Armas, 'The role of the judiciary in climate change' available at https://law.stanford.edu/2015/10/11/role-judiciary-climatechange/ (accessed 20 September 2018).

128 See generally, Yuhong Zhao, 'Environmental dispute resolution in China' (2004) 16(2) Journal of Environmental Law at 157-192.

129 UN Environmetal Program, 'The role of legal instruments to support green lowemission and climate-resilient development' http://www.undp.org/content/ dam/undp/library/Environment\%20and\%20Energy/Climate\%20Strategies/LECRDS _Legal_Guide.pdf (accessed 12 September 2018). 


\section{Mechanisms for loss and damage}

As a result of a failure to have resilient measures against climate change, loss and damage becomes the consequence. Loss and damage is the term used in climate policy for the worst impacts of climate change - those that go beyond people's ability to cope and adapt. It includes extreme events, like droughts and tropical storms, and slowonset events like sea-level rise, increasing temperatures, glacial retreat causing flooding and eventual drought, and desertification. ${ }^{130}$ Climate Focus Client Brief on the Paris Agreement IV defines loss and damage as:

Sudden and slow-onset events of climate change which cause harm in developed and developing countries alike. Conceptually, loss and damage arises when the adverse effects are not avoided through mitigation and adaptation. In the UNFCCC context, loss and damage involves the development of approaches to address the effects of such events on the most vulnerable developing countries, who are recognised as bearing disproportionate costs from climate change, having both contributed the least to the problem and the least capacity to manage its negative impacts. ${ }^{131}$

The best aspect of climate justice is the enforcement of mechanisms for accessing and proper award of damages and apportioning of loss to deserving parties. Meanwhile, in ensuring that these mechanisms are fully implemented, suggested areas include but are not limited to, enhancing knowledge and understanding of risk management approaches; strengthening dialogue, coordination, coherence and synergies among relevant stakeholders; enhancing action and support on loss and damage, including finance, technology and capacity building, etc. Many climate change researchers and practitioners argue that to best facilitate resilience-building, loss and damage action should aim to result in multiple benefits to nations and communities, such as sustainable development and poverty reduction gains. ${ }^{132}$

The Warsaw International Mechanism for Loss and Damage (WIM) was established at COP-19 (Conference of Parties) in 2013. WIM is the main institution under the UNFCCC to address loss and damage associated with the impacts of climate change, including extreme and

130 K Boom, J Richards \& S Leonard 'Climate justice: The international momentum towards climate litigation' available at https://www.boell.de/sites/default/ files/report-climate-justice-2016.pdf (accessed 18 September 2018) 8.

131 Climate Focus, 'Loss and damage in the Paris Agreement' available at http:// www.climatefocus.com/sites/default/files/20160214\%20Loss\%20and\%20Damage \%20Paris_FIN.pdf (accessed 16 September 2018).

132 A Durand \& SaleemulHuq, 'A Simple Guide to the Warsaw International Mechanism on Loss and Damage' available at http://www.icccad.net/wpcontent/ uploads/2015/09/A-simple-guide-to-the-Warsaw-InternationalMechanism.pdf (accessed 17 September 2018). 
slow onset events, in developing countries that are particularly vulnerable to the adverse impacts of climate change. WIM has three key functions:

(1) enhancing knowledge and understanding loss and damage and how to address it;

(2) strengthening dialogue among relevant stakeholders; and

(3) enhancing action and support on loss and damage, including in the areas of finance, technology and capacity building. ${ }^{133}$

Whether WIM will be enough to meet the needs of vulnerable countries in managing the challenge of loss and damage will be judged over time. WIM is not (yet) meant to be an instrument for delivering much needed additional finance to poor countries and communities. However, it can lay the basis for a meaningful response from the international community. ${ }^{134}$

\subsection{Adequate insurance mechanism}

The provision of an adequate insurance mechanism can alleviate the plight of the victims of climate disasters. Thus, climate-risk insurance has the following potential benefits:

(a) It helps promote guaranteed, timely finance, and provides farmers with financial liquidity in the aftermath of extreme weather events and prevents the farmer from falling into the trap of poverty as a result of losses incurred due to climate impacts.

(b) Agricultural insurance results in stabilising income in the entire agriculture value chain, resulting in improved food security, secured future food production and secured financing options as a result of stable income. Revenues for agricultural businesses (seeds, fertilizers) are also stabilised by sales to farmers and elaborated customer base as a result of subsidised insurance.

(c) It facilitates risk management practices.

(d) It is also transformative in terms of promoting a planned, systematic and well-designed approach to risk rather than ad-hoc crisis response. ${ }^{135}$

Meanwhile, key limitations of insurance include: (1) it does not prevent or reduce the likelihood of direct damage and fatalities from extreme weather events; and (2) it is not always the most appropriate option to manage risks (for example, in terms of cost-effectiveness or affordability). These same limitations are potentially aggravated in a climate change context (i.e. more frequent and intense extreme

133 J Kreienkamp \& L Vanhala 'Climate Change Loss and Damage' available at https: / / www.ucl.ac.uk/global-governance/downloads/policybriefs/policybrief-loss-anddamage (accessed 19 September 2018).

134 Ryall (n 111) at 45.

135 Bond Development and Environment Group (DEG) 'Equitable, Effective and Propoor Climate Risk Insurance Working Paper.' Available at https://www.bond. org.uk/sites/default/files/resourcedocuments/deg_climate_risk_insurance_aug ust_2016.pdf (accessed 18 September 2018). 
events). Climate change also poses additional challenges for insurance, a point that further underscores the vital importance of disaster risk reduction. Two of these issues include: potential uninsurability associated with increasing frequency and magnitude of extreme weather events and unsuitability of traditional insurance for longer-term foreseeable hazards like sea-level rise and desertification. ${ }^{136}$ However, the government, legal community and civil societies should ensure the provision of insurance to climate change prone areas to increase surveillance, because insurance can be seen as an important tool for addressing climate change and disaster risk management, in addition to other prevention and security measures such as, development of a disaster modelling system beyond risk sharing and incorporation of risk management cycle into the government budget planning. When properly designed, the insurance system can be used as a market-based instrument against moral hazards and influencing risk behaviour. It can also positively impact awareness raising and disaster proofing for adaptation actions and financial decisions. ${ }^{137}$

\subsection{Adequate finance for loss and damage}

The government can legislate stiffer and stringent laws to help improve climate justice. For instance, in Nigeria, Paragraph 8.1 of EGASPIN69 provides that 'a spiller shall be liable for the damage from a spill for which he is responsible. ${ }^{138}$ Where more than one spiller is liable, the liability shall be joint and several.'139

Some governments, especially in developing countries, shy away from being signatories to international conventions for example, the Paris Agreement. ${ }^{140}$ Therefore, other international treaties that are aimed at building resilience and encourage fight for climate justice should be opted into by African countries, and they are encouraged to participate actively.

136 Munich Climate Insurance Initiative, 'Adaptation to Climate Change: Linking Disaster Risk Reduction and Insurance' available at http://unfccc.int/resource/ docs/2009/smsn/ngo/163.pdf (accessed 21 September 2018).

137 World Bank Group, 'Insurance against Climate Change', available at http:// www.moew.government.bg/static/media/ups/tiny/file/Climate/Insurance_Again st_Climate_Change.pdf (accessed 21 September 2018).

138 Environmental Guidelines and Standards for the petroleum Industry in Nigeria 200 published by the Department of Petroleum Resources (DPR) para 8.1, 'Liability'.

139 Further, Article 41 of Environmental Protection Law of China provides that 'those who have caused environmental population and damage shall eliminate harm and pay compensation to the units or individuals directly injured by the harm'.

140 The Paris Agreement builds upon the Convention and - for the first time - brings all nations into a common cause to undertake ambitious efforts to combat climate change and adapt to its effects, with enhanced support to assist developing countries to do so. As such, it charts a new course in the global climate effort. The Paris Agreement's central aim is to strengthen the global response to the threat of climate change by keeping a global temperature rise this century well below $2^{\circ} \mathrm{C}$ above pre-industrial levels and to pursue efforts to 
The United Nations Framework Convention on Climate Change (UNFCCC) texts specify a wide range of elements of funding provision for loss and damage. They outline an assortment of approaches for preventing and dealing with loss and damage (including inter alia financial support for development of insurance schemes and risk transfer mechanisms, early warning systems, emergency preparedness measures). It discusses the provision of financial support for parties' efforts to implement their own risk management strategies and for the financial support for international institutions. ${ }^{141}$ The bane has always been the full implementation of the provisions of the Convention. Therefore, Member States are encouraged to give effect to those provisions.

In addition, innovative finance mechanisms could provide a viable way to mobilise predictable funding for loss and damage. The idea of a global carbon tax, a financial transaction tax, an international airline passenger levy or a fossil fuel extraction levy has received particular attention. On a global level, however, these mechanisms remain largely untested so far. Inevitably, they will also raise questions about how finance should be distributed. ${ }^{142}$

\subsection{Addressing climate migration}

Climate change, on its own, does not directly displace people or cause them to move but it produces environmental effects and exacerbates current vulnerabilities that make it difficult for people to survive where they are. ${ }^{143}$ It is expected to make the world hotter, rainfall more intense, and result in more extreme weather events such as droughts, storms and floods. ${ }^{144}$ These changes, in turn, will likely result in further population movements. According to the UN

limit the temperature increase even further to $1.5^{\circ} \mathrm{C}$. Additionally, the agreement aims to strengthen the ability of countries to deal with the impacts of climate change. To reach these ambitious goals, appropriate financial flows, a new technology framework and an enhanced capacity building framework will be put in place, thus supporting action by developing countries and the most vulnerable countries, in line with their own national objectives. The Agreement also provides for enhanced transparency of action and support through a more robust transparency framework. Culled from United Nations Framework Convention on Climate Change, 'Paris Agreement' http://unfccc.int/paris_agree ment/items/9485.php (accessed 12 September 2018).

141 A Durand \& others Financing options for loss and damage: A review and roadmap, available at https://unfccc.int/files/adaptation/groups_committees/loss_and_ damage_executive_committee/application/pdf/browncdlicccadfinancinglossand damagepaperdraft.pdf (accessed 19 September 2018)

142 Ryall (n 111) at 45.

143 United Nations High Commissioner for Refugees (UNHCR) 'Climate change and disaster displacement', available at https: //Www.unhcr.org/climate-change-anddisasters.html (accessed 10 October 2019).

144 International Organisation for Migration (IOM), Migration, Environment and Climate Change: Accessing the Evidence' available at http://publi cations.iom.int/system/files/pdf/migration_and_environment.pdf (accessed 21 September 2018). 
International Strategy for Disaster Reduction (UNISDR) - storms, floods and droughts - have increased threefold over the past 30 years. ${ }^{145}$ Some environmental changes, such as hurricanes and earthquakes, occur with little or no warning and require that people move quickly. Others develop more slowly and may provide time for people to assess their options, leave in an orderly manner and even bring resources with them. However, certain thresholds or 'tipping points' may be reached, where there is little choice left but to move.

The extent to which the environment, including climate change, is the primary driver of migration remains debatable for several reasons. Migration can also affect the environment in terms of additional stress on already degraded lands and competition for scarce resources in both rural and urban settings. ${ }^{146}$

In addressing climate migration, the government and the legal community can formulate policy response and legal framework, respectively. More efforts are needed to identify, test and implement new programmes, policies and frameworks to manage future movements of people linked to environmental and climate change. The capacities of governments to implement existing ones need to be enhanced. Migration can be among several adaptation strategies as exemplified in several National Adaptation Programmes of Action (NAPAs). Countries of destination lack coherent policies to address potential future flows. Measures specifically targeting migration in relation to the environment are ad hoc at best. ${ }^{147}$

Meanwhile, in the event of movement of persons, civil society groups can help provide alternative destinations. Most times, those affected have no other place to go. Hence, the creation of an internally or internationally displaced people's camp can help mitigate the sufferings of the displaced persons.

\section{Conclusion}

Climate change is a world problem. Unfortunately, these problems are exacerbated by reluctant approaches to stimulate resilience. The principle of good governance is essential to the rule of law. In the climate change context, it requires the enactment and enforcement of clear and effective laws that support sustainable developmentdevelopment that meets the needs of the present generation without compromising the ability of future generations to meet their own needs. On the other hand, many victims of climate justice have suffered huge environmental losses and damage without adequate 
compensation from the perpetrators of the injustice. Thus, the role of civil society groups in monitoring the implementation of international treaties, their relevance in the organisation of development projects, and their importance in the representation and education of the society has been acknowledged and valued by both international organisations and national governments. ${ }^{148}$

The role of the international community to advance climate resilience and climate justice cannot be overstated. For instance, WIM created approaches to ensure adequate compensation for climate injustice. In the same vein, the legal community, through a reassurance of justice can effectively harmonise and ensure climate justice, especially as the cases come to court. The legal community, i.e. the courts and the legal professionals, have a higher burden to integrate human rights into climate actions - through the fight for human rights.

Summarily, there are identified challenges to the full actualisation of climate resilience and the fight for climate justice. Some of these challenges include a lack of enforcement of climate laws, reluctance of governments to collect and provide requisite information required to make informed decisions, corruption and inefficiency, undue political interference with the work of regulatory agencies, inconsistent political positions and structures, abject poverty and lack of knowledge, and in the oil producing states, overdependence on oil which has adverse environmental effects. ${ }^{149}$ We need to act decisively to change humanity's relationship with our planet based on the concept of 'common but differentiated responsibility' recognising the need for global action and the differing levels of obligations placed upon industrialised and developing countries. The key to achieving climate resilience and climate justice is for the government, courts, legal professionals, civil organisations and stakeholders to effectively play their roles in making the world a better place.

148 Giorge (n 14) 115.

149 An environmental effect means a natural or artificial disturbance of the physical, chemical, or biological components that make up the environment. See also BA Garner, Black's Law Dictionary, (9th ed) (2009) 614. 


\section{CASE NOTE:}

\section{STEPPING IN THE RIGHT DIRECTION TOWARDS FULLY REALISING THE CONSTITUTIONAL PROMISE OF SECTION 29(1)(A) OF THE CONSTITUTION}

Federation of Governing Bodies for South African Schools (FEDSAS) v Member of the Executive Council for Education, Gauteng and Another 2016 (4) SA 546 (CC)*

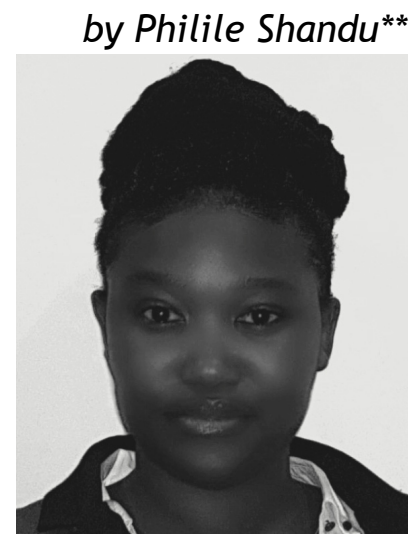

\section{Introduction}

On 20 May 2016, the Constitutional Court of South Africa ('CC') granted the Federation of Governing Bodies for South African Schools ('FEDSAS') leave to appeal an order from the Supreme Court of Appeal. ${ }^{1}$ The applicant, FEDSAS, a national organisation representing school governing bodies, sought an order to invalidate amendments

* This case note constitutes an adapted version of my submission in fulfilment of LLB requirements with the University of South Africa (UNISA).

** Philile Shandu is an LLM candidate at the University of Kwazulu Natal (UKZN).

1 Member of the Executive Council for Education, Gauteng and Another $v$ Federation of Governing Bodies for South African Schools 20154 All SA 591 (SCA). 
made to certain 'regulations relating to the admission of learners to public schools'. 2 The applicant argued that that the amendments were beyond the scope of namely; section 5(5) of the South African Schools' Act ('Schools Act') and section 11(1) of the Gauteng Schools Education Act, which respectively relate to admission policies in public schools and regulations thereof. ${ }^{3}$

The CC dismissed the appeal and found the amendments in the regulations to be rational, reasonable and justifiable. ${ }^{4}$ The court further directed the Member of the Executive Council ('MEC') for Education of Gauteng to determine the feeder zones for public schools in Gauteng, no later than twelve (12) months from the date of judgment.

In the unanimous judgment delivered by Moseneke DCJ, the court acknowledged the detrimental effect of the denial of access to education and training. ${ }^{5}$ The court stated that '(a)ll forms of human oppression and exclusion are premised [...]' on the obstruction of this basic human right. ${ }^{6}$ Owing to South Africa's history of institutionalised discrimination, its citizens have both the benefit and burden of appreciating the substance of this assertion. ${ }^{7}$ In 1994, poorly qualified teachers and inadequate infrastructure in public schools that was designated to non-white learners further served as a barricade preventing access to quality education. 8 Many curative steps have been taken since the adoption of the 1996 Constitution. 9 However, the residual hierarchy of privilege and disadvantage that was created by inequity is the backdrop of FEDSAS's application to the Constitutional Court. ${ }^{10}$

2 Regulation 3(7), regulation 4(2) read with 4(1), regulation 5 read with 8, regulation 11(5) and regulation 16 of the Gauteng School Education Act 6 of 1995: Regulations Relating to the Admission of Learners to Public Schools, 2012, GN 1160 Provincial Gazette 127, 9 May 2012.

3 Gauteng Schools Education Act 6 of 1995 \& South African Schools Act 84 of 1996.

4 Federation of Governing Bodies for South African Schools (FEDSAS) v Member of the Executive Council for Education, Gauteng and Another 2016 (4) SA 546 (CC) para 46. Herein after referred to as the 'The FEDSAS case'.

5 The FEDSAS case (n 4) para 3.

6 As above.

7 Based on the policy of apartheid, upon which various laws were formulated to promote segregation.

8 F Maringe \& M Prew (eds) Twenty years of education transformation in Gauteng 1994 to 2014: An independent review (2014) 84. According to this source, only $54 \%$ of black educators were appropriately qualified.

9 The Constitution of the Republic of South Africa, 1996. Hereinafter 'the Constitution of the Republic of South Africa'.

10 Head of Department, Mpumalanga Department of Education and Another $v$ Hoërskool Ermelo and Another 2010 (3) BCLR 177 (CC). 
Central to this case is section 29(1)(a) of the Constitution which endows everyone with the right to basic education. Like any other right in the Bill of Rights, the right to education may be limited in terms of the law of general application. ${ }^{11}$ However, this constitutional promise exists in the context of poverty, unemployment and inequality - all factors that contribute to unequal access to quality education. ${ }^{12}$ These factors have played a more significant role in limiting the right to access to basic education than section 36 (1) of the constitution ever will.

To realise and extend section 29(1)(a) of the Constitution, the South African legislature adopted Schools Act with the aim of providing an education system that facilitates the advancement of the democratic transformation of society. ${ }^{13}$ This Act was enacted to, among other things, 'redress past injustices in educational provision, provide an education of progressively high quality for all learners (and) combat racism and sexism and all other forms of unfair discrimination. ${ }^{14}$ Although the Schools Act intends to provide quality and better education, there have been numerous constitutional challenges under section 5(5) of the Act, which authorises student governing bodies ('SGBs') to determine the admission policies of their respective schools. ${ }^{15}$ This provision has created the opportunity for SGBs to implement gate-keeping tactics based on inter alia, geography, language, financial status and intellectual ability, as discussed below. ${ }^{16}$

This decision comes after a protracted legal tug-of-war between the Gauteng Department of Education and various SGBs relating to school admissions. ${ }^{17}$ The importance of this particular case is that

11 Governing Body of the Juma Musjid Primary School \& Others $v$ Essay NO and Others 2011 (8) BCLR 761 (CC).

12 These factors have been collectively termed as South Africa's 'triple challenge' https://www.parliament.gov.za/storage/app/media/Pages/2017/october/High Level_Panel/HLP_Report/HLP_WG1_CDE_Draft_Report_response_to_committees_ comments_24.4.17.pdf accessed on 23 August 2019).

13 Preamble of the South African Schools Act 84 of 1996.

14 As above.

15 For example; Head of Department, Mpumalanga Department of Education and Another V Hoërskool Ermelo and Another 2010 (2) SA 415 (CC); Head of Department, Department of Education, Free State Province $v$ Welkom High School and Others 2013 (9) BCLR 989 (CC) and MEC For Education, Gauteng Province and Others $v$ Governing Body, Rivonia Primary School and Others 2013 (12) BCLR 1365 (CC)).

16 The FEDSAS case (n 4) para 32: 'The respondents set out uncontested facts on the Department's experience relating to admission patterns. Schools that are told in advance of admission that a learner has learning or remedial difficulties or is troublesome, tend to refuse that learner's admission. Schools would rather have higher achieving learners and better results.'

17 For example; Head of Department, Mpumalanga Department of Education and Another $v$ Hoërskool Ermelo and Another 2010 (2) SA 415 (CC); Head of Department, Department of Education, Free State Province $v$ Welkom High School and Others 2013 (9) BCLR 989 (CC) and MEC For Education, Gauteng Province and Others v Governing Body, Rivonia Primary School and Others 2013 (12) BCLR 1365 (CC)). 
FEDSAS's application to the CC inadvertently served as an instrument to develop the law as it pertains to the right envisaged in section 29(1)(a) of the Constitution. Notwithstanding all other factors which have the potential to limit this right, the rules developed in seeking to realise the promise of access to quality basic education as entrenched in the Constitution, are reinforced by this judgment thereby bringing South Africa closer to Constitution's aspiration of 'Improv(ing) the quality of life of all citizens and free(ing) the potential of each person.'18

This note discusses the critical facts controlling the issues of the FEDSAS case, the court's holding and reasoning thereof, prior litigation regarding admissions to public schools and how the court's decision actualises the right envisaged in section 29(1)(a).

\section{Court decisions analysis}

\subsection{The High Court judgment}

Acting on the MEC's invitation to submit comments on draft amendments to Regulations published in July 2011, the FEDSAS made submissions in August 2011 highlighting their concerns regarding 29 provisions. ${ }^{19}$ After the MEC had given FEDSAS's input serious consideration, alterations were made, leaving FEDSAS displeased with the outcome. FEDSAS then approached the South Gauteng High Court ('High Court') to challenge the validity of specific regulations on the ground that they were in conflict with the section 5(5) of the Schools Act, the National Education Policy Act, the Admission Policy for Ordinary Public Schools and the Gauteng Education Policy Act. ${ }^{20}$ FEDSAS further alleged that the regulations were ultra vires, considering the powers conferred on the MEC by section 11(1) of the Gauteng School Education Act. It was further argued that they were unreasonable and unjustifiable in terms of section 4 of the Gauteng Schools Education Act. ${ }^{21}$ The court set aside regulation 2(2A),

18 Preamble of the Constitution of the Republic of South Africa ( $n$ 9). Most importantly in relation to this paragraph, the Preamble states that, "this country requires a new national system for schools which will provide an education of progressively high quality for all learners'. The 'rules developed in seeking to realise the promise of access to quality basic education' are found in the South African Schools Act of 1996.

19 General Notice 1929 of 2011, Provincial Gazette 154 of 18 July 2011.

20 Gauteng Education Policy Act 12 of 1998. See also National Education Policy Act 27 of 1996 ('NEPA') and sec 3(4)(i) of NEPA in GN 2432, GG 19377 of 19 October 1998 , as published by the Minister of Education.

21 The FEDSAS case (n 4) para 14. 
regulation $3(7)$, regulation 4 , regulation 5 and regulation 16 on grounds proffered by the applicant. ${ }^{22}$

\subsection{Supreme Court of Appeal}

The MEC and Head of Department for Education in Gauteng (HOD) approached the Supreme Court of Appeal (SCA) seeking to appeal the decision of the High Court. ${ }^{23}$ The SCA upheld the appeal with costs, finding no substantive or procedural defects with the regulations, save for Regulation 2(2A) which was declared invalid and of no force and effect, thereby setting aside the High Court judgment in part. ${ }^{24}$

Regulation 2(2A) provided that ' $\mathrm{t}] \mathrm{h}$ he Department may determine the minimum standards for the formulation of the admissions policy for specialist schools, technical schools and education institution. 25 The Supreme Court of Appeal struck down this regulation on the grounds that the inclusion of 'education institutions' in the regulation detracts from its main purpose. ${ }^{26}$

The court saved the rest of the contested regulations on the basis that they were reasonable, rational, and not ultra vires nor were they in conflict with national law. ${ }^{27}$

\section{Issues before the Constitutional Court}

FEDSAS brought the matter to the Constitutional Court, seeking a leave to appeal the Supreme Court of Appeal judgment. ${ }^{28}$ The issue before court was on the same facts and legal question of unconstitutionality of the regulations. The respondents (Gauteng MEC for Education in Gauteng) and HOD for Education in Gauteng, opposed the appeal on the basis that the impugned regulations were rational, reasonable, and designed to prevent unfair discrimination in the process of school admissions. ${ }^{29}$

22 The High Court held the following: that regulation 16 was ultra vires; that a procedural defect invalidated regulation 2(2A); that regulation 3(7) was unjustifiable and unreasonable; that regulation 4 was beyond the power given by section 11(1) and invalid; and that regulation 5, save for regulation 5(5), was ultra vires and invalid.

23 The FEDSAS case (n 4) para 14.

24 As above.

25 Gauteng School Education Act 6 of 1995: Regulations Relating to the Admission of Learners to Public Schools, 2012, GN 1160 Provincial Gazette 127, 9 May 2012.

26 The FEDSAS case (n 4) para 17.

27 The FEDSAS case (n 4) para 18 - 20.

28 The appeal relates to regulation $3(7)$, regulation $4(2)$ read with regulation $4(1)$, regulation 5 read with regulation 8, regulation 11(5) and regulation 16 of Gauteng School Education Act 6 of 1995: Regulations Relating to the Admission of Learners to Public Schools, 2012, GN 1160 Provincial Gazette 127, 9 May 2012. The FEDSAS case (n 4) paras 31 \& 41. 


\section{Constitutional Court's decision and rationale}

\subsection{Leave to appeal}

Leave to appeal the specified orders of the Supreme Court of Appeal was granted by the CC. ${ }^{30}$ The court based this decision on the fact that the application raised 'important constitutional questions of equitable access to education - a promise made by section 29 of the Constitution. 31 The court noted that, while the dispute between SGBs and provincial government was not new to the CC, the significance of the questions before it and the public interest thereof supported the applicant's bid to be heard on the matter. ${ }^{32}$ Furthermore, the application required the Court to interpret national and provincial legislation in light of the Constitution - a competency of the Constitutional Court.

\subsection{Conflict between national and provincial legislation}

FEDSAS asserted that regulation 5 , read with regulation 8 , caused a conflict between national and provincial legislation. ${ }^{33}$ The applicant insisted that provincial legislation, which is in conflict with national, should be declared invalid by the court. However, the CC did not assent to their prayer.

According to schedule 4 of the Constitution, education is one of the areas that both the national and provincial have concurrent powers. This means that both these levels of government may enact legislation that deals with educational issues. The Minister of Basic Education exercises executive authority at a national level. ${ }^{34}$ Whereas, in cases where that the provincial legislature would enact legislation, the executive authority to implement such legislation vests in the Premier and other MECs in a province. ${ }^{35}$ Based on this, the court accepted the overlap of national and provincial legislation and further cited the conflict resolution scheme of sections 146, 149 and 150 of the Constitution to confirm that '[a]utomatic repugnancy between the two classes of legislation does not arise.'36

Order 3 and 4(a) of Member of the Executive Council for Education, Gauteng and Another v Federation of Governing Bodies for South African Schools 20154 All SA 591 (SCA).

31 The FEDSAS case (n 4) paras 23.

32 The FEDSAS case (n 4) paras 4 \& 23.

33 The FEDSAS case (n 4) para 25.

34 P De Vos \& W Freedman (eds) South African Constitution in context (2014) 196.

35 Sec 125(2)(a) of the Constitution of the Republic of South Africa (n 9).

36 The FEDSAS case (n 4) para 27. Also note in terms of the Constitution, sec 146 addresses conflicts between national and provincial legislation. Sec 149 addresses the issue of status of legislation that does not prevail. Sec 150 provides for the interpretation of conflicts. 
The court found that regulations 5 and 8 were consistent with sections 5(1) to (5) of the Schools Act and the National Education Policy Act, given the limitations in sections 5(1) to (3) of the Schools Act and the provincial law ordered by section 5(5) of the Schools Act. ${ }^{37}$

\subsection{Impugned regulations}

Regulation 3(7) prohibits schools from requesting confidential information of learners from their current school before admission. The court rejected the applicant's suggestion for the regulation to be narrowed by listing specific information on what is permissible or not permissible information to access in order to allow schools to 'discriminate fairly.' 38 The court found that the regulation's purpose to prevent unfair discrimination against a learner during the admission phase was a legitimate one.

Regulation 4(1) and (2) provides that MEC, by notice in the Provincial Gazette, may determine the feeder zone for any school in the Province, after consultation with the relevant stakeholders have been conducted. In their submissions, the applicant and the Amicus Curiae argued that the inclusion of the non-peremptory word 'may' in regulation 4(1) was problematic. ${ }^{39}$ They stated that it would leave the creation of a permanent default regime of feeder zones, as well as the envisaged consultation, to the MEC's discretion. The court found that the unilateral determination of default feeder zones denied SGBs, as stakeholders, meaningful participation in this process. ${ }^{40}$ The MEC was thus directed to set feeder zones no later than twelve (12) months from the date of the order.

The court then examined regulation 5 which provides that at the end of the admission period, the District Director may place any unplaced learner at any school that has not been declared full. This regulation was read with regulation 8 , which stipulated that 'the objective entry level learner enrolment capacity of a school shall be determined by the (HOD)' who may also declare the school full if the school has reached its enrolment capacity. The applicant and amicus challenged these provisions for their irrationality and divergence from section 5 of the Schools Act. In response to this, the court emphasised that section 5(5) of the Schools Act which declares that '(s)ubject to

37 The FEDSAS case (n 4) para 29.

38 The FEDSAS case (n 4) para 30.

39 The court admitted Equal Education, a membership-based democratic movement of learners, teachers, parents and community members as Amicus Curiae. Herein after referred to as 'amicus.'

40 The FEDSAS case (n 4) para 37. 
this Act and any applicable provincial law, the admission policy of a public school is determined by the governing body of such school.,41 This clearly demonstrated that the SGB's admissions autonomy was limited to any provisions of the School Act and any other relevant law - in this case, the regulations. The court further cited the Rivonia Primary School case, wherein this textual qualifier was acknowledged and accepted. ${ }^{42}$ Owing to this, the court found regulation 5 , read with regulation 8 , to be rational, reasonable and justifiable. ${ }^{43}$

Furthermore, the court probed the merits of regulation 16 . This regulation relates to processes available to parents who wish to object to or appeal decisions regarding admission. A primary appeal / objection stratum, wherein parents can petition the HOD before appealing to the MEC, was introduced by this regulation. The court found that this regulation did not amount to 'a delegation of authority by the MEC to the HOD to decide an appeal, 'and therefore found that it was not necessary to further enquire whether this regulation transgressed the bounds of section 105 of the Gauteng School Education Act which regulates delegation of power and assignment of duties. ${ }^{44}$

Lastly, consistent with the Biowatch judgment, the court did not impose costs of the application on FEDSAS, as it had 'raised important constitutional questions. ${ }^{\prime 45}$

\section{History of litigation regarding public schools' admissions}

The CC has adjudicated several disputes involving SGBs and provincial governments in the past and a recurring theme in the case law involving these parties has been the principle of co-operative governance. ${ }^{46}$ The Constitution divides government into national, provincial and local spheres, and directs these three (3)

distinctive, interdependent and interrelated' spheres to 'co-operate with one another in mutual trust and good faith by fostering friendly relations, assisting and supporting one another, informing one another of... matters of common interest, co-ordinating their actions and

41 Sec 5(5) of the South African Schools Act 84 of 1996.

42 MEC for Education, Gauteng Province and Others $v$ Governing Body, Rivonia Primary School and Others 2013 (12) BCLR 1365 (CC). Herein after referred to as 'The Rivonia case.'

43 The FEDSAS case (n 4) para 46.

44 The FEDSAS case (n 4) para 49.

45 The FEDSAS case ( $\mathrm{n} 4)$ para 50. See also Biowatch Trust $v$ Registrar, Genetic Resources and Others 2009 (6) SA 232 (CC).

46 The FEDSAS case (n 4) para 47. 
legislation with one another, adhering to agreed procedures and avoiding

legal proceedings against one another. ${ }^{47}$

The same can be applied to the 'three-tier partnership' of national and provincial governments and SGBs. ${ }^{48}$

The court hearing the FEDSAS case reiterated the scheme of cooperative governance among these organs of state and noted the incidence of legal proceedings involving these parties. ${ }^{49}$ In his Rivonia Primary judgement, Mhlantla AJ emphasised the need for engagement amongst these constant litigants, particularly for the furtherance of the interests of learners. ${ }^{50}$ Regrettably, the best interests of learners are seemingly lost in the various cases where each party has sought to assert their respective statutory mandate above that of the other.

\section{Realising the objects of section 29(1)(a)}

Addressing the real problem of uneven access to education by statutes has proven to be inadequate. While the right to access to basic education has been entrenched in the Constitution since 1996, it has been made practical over the years by regulation, school policy, administrative action and case law, a judgment at a time.

There are many obstacles standing between the right envisaged by section 29(1)(a) and its practical realisation. Among these obstacles has been unfair discrimination on various grounds, which this case addresses. The court's acceptance of regulation 3(7), particularly, is a giant leap forward towards making schools' admission practices more inclusive. Barring schools from obtaining information which could be used as grounds for unfair discrimination encourages (colour) blind admissions and eliminates the unwarranted differential treatment of learners that does not serve the public interest or purpose. $^{51}$

Physical and economic accessibility to education are yet to be dealt with by this court. However, the entrenchment of nondiscriminatory admission practices through the court's avowal of regulation $3(7)$, regulation 5 read with 8 , and $11(5)$ is happily welcomed.

47 Sec 41(1) of the Constitution of the Republic of South Africa ( $\mathrm{n} 9$ ).

48 The Rivonia case (n 42) para 36.

49 The FEDSAS case (n 4) para 47.

50 The Rivonia case (n 42) para 48(d).

51 Art 4 of the Convention Against Discrimination in Education, concluded 14 December 1960 and entered into force 22 May 1962. 


\section{Developments}

Although the MEC failed to meet the twelve (12) month deadline set by the court, an application for an extension was granted and the MEC was given a further eighteen (18) months to expand the province's feeder zones in order to address apartheid spatial planning. ${ }^{52}$ The determination of such involved consultations with stakeholders such as SGB associations, the advocacy group Equal Education, the Premier's office and the Municipal Demarcation board. ${ }^{53}$

On 15 November 2018, after almost two years after the order was made, the Gauteng education announced that all schools in the province would now have a feeder zone within a $30 \mathrm{~km}$ radius, as opposed to the previous $5 \mathrm{~km} .{ }^{54}$ In practicality, this means that a pupil residing in Alexandra township can now be admitted to Parktown High School for Girls, a former 'model C' school which achieved a $100 \%$ pass rate and a 98,1\% degree entrance in 2018. ${ }^{55}$

Speaking to the Mail \& Guardian after this announcement, Gauteng Education MEC Panyaza Lesufi confirmed the significance of this judgment and its consequences, saying,

Feeder zone determination plays a significant role in ensuring that access to our schools is fair, transparent and conducted in an equitable manner. Our schools cannot justify any form of discrimination against any learner. ${ }^{56}$

\section{Conclusion}

This judgment serves to clear the murky waters of ostensibly conflicting national and provincial laws, in order to emphasise reasonableness as an essential element in the exercise of power and to encourage non-discriminatory admission practices in schools.

52 Gemma Ritchie 'Gauteng school feeder zones expanded to 30km' 16 Nov 2018 https://mg.co.za/article/2018-11-16-00-gauteng-school-feeder-zones-expandedto-30km (accessed 10 June 2019).

53 As above.

54 As above.

55 https://www.parktowngirls.co.za/matric-results-2018 (accessed 12 June 2019). See also schools now referred to as quantile 5 schools. Dass $S$ and Rinquest $A$ 'Chapter 7: school fees' in 'Basic Education Rights Handbook: Education Rights in South Africa' htpp://section27.org.za/basic-education-handbook (accessed 15 June 2017).

56 Ritchie (n 52). 
The FEDSAS case makes it clear that fulfilling the constitutional promise contained in section 29(1)(a) will require more than just making educators and school infrastructure available for teaching and learning. ${ }^{57}$ The complete realisation of this right will entail addressing relics of apartheid such as, school admissions policies based on the pre-constitutional era spatial planning and exclusionary language policies. ${ }^{58}$ While these are not the only barriers to education, in the context of South Africa's history of discrimination and inequality, these issues cannot be ignored when developing education policies. ${ }^{59}$

In order to give practical meaning to the right to access to basic education, the South African Schools Act was enacted to 'redress past injustices in educational provision, provide an education of progressively high quality for all learners (and) combat racism and sexism and all other forms of unfair discrimination. 60 The CC's rationale in the FEDSAS case echoes this objective and serves as a major legal development in the area of education law in South Africa.

57 Everyone has the right to a basic education, including adult basic education. The author avers that this subsection creates an expectation for access to such basic education, hence making this a promise that should be fulfilled by the Executive branch of government.

58 For example, policy in contention in Mpumalanga Department of Education and Another v Hoërskool Ermelo and Another 2010 (2) SA 415 (CC).

59 According to UNESCO's EFA global monitoring report 2015, the main barriers of access to education are poverty, poor quality of education, physical inaccessibility of schools, gender and unemployment. https://unesdoc.unesco. org/ark: / 48223/pf0000232205?posInSet=1\&queryld=36deb540-0411-43d3-b932 a63507ab9ffc (accessed 7 August 2019).

60 Preamble of the South African Schools Act 84 of 1996. 


\section{THE FEMINIST AGENDA, A FALL OF HIERARCHAL REDRESS OR AN ATTEMPT TO ESTABLISHING AN 'EQUAL' SOCIETY GONE WRONG: AN INTERNAL CRITIQUE TO FEMINIST THEORIES*}

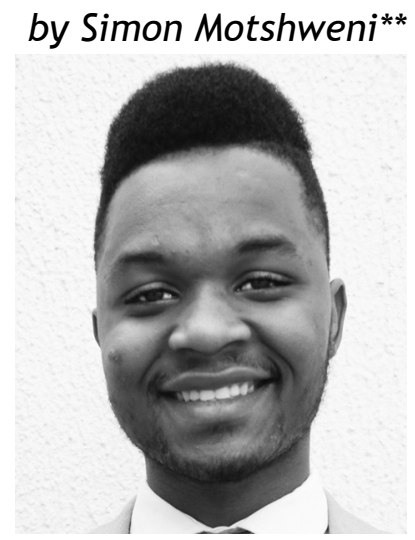

'To be fully subversive, the methodology of feminist legal theory should challenge not only law's content but its tendency to privilege the abstract and unitary voice and this gender essentialism also fails to do' ${ }^{1}$

* The aim of this paper is not to come to the defense of patriarchal systems of domination or perpetuate the subjugation of women in a male dominated legal order. I also acknowledge that as a man, I may not be 'best positioned' to talk about feminism as I do not have the lived experiences of the subjugation of women in society and feminists would argue that I 'enjoy' a position of an unwarranted privilege. However, I wish to make clear that the jurisprudential differences regarding the role and impact of feminist legal theories to the subject of law are a persistent 'conscious raising exercise' in legal philosophy and this paper merely aims to extend the existing literature on the subject of feminism in jurisprudential discourse. Nonetheless, Feminism is for Everyone, isn't it ...?

** Third year LL.B, University of Pretoria, 2019. I would like to thank Ms Zenia Pero for her critical engagement, advice, feedback and patience while I was writing this paper; Mpho Mogadime, Thato Maruapula and Franciscus Crouse for their feedback and review comments. All errors, omissions and shortcomings are undoubtedly my own.

1 A Harris 'Race and Essentialism in Feminist Legal Theory' (1990) 3 Stanford Law Review at 581. 


\section{Introduction}

The aim of this paper is to interrogate the post-1994 feminist approaches to jurisprudential discourse. This interrogation will include a consideration as to whether critical instead of 'traditional' feminist theories contribute in transforming or decolonising South African law and jurisprudence. It is my suggestion that the inquiry to address 'gender equality' before and without addressing issues of racism and racial classism simultaneously in South Africa contributes effectively to the continued marginalisation of black women. As such, my position attempts to engage with the critical feminist approaches in order to address the prejudices that traditional feminist approaches impose on black women.

The focal theoretical point of departure for this interrogation is critical race feminism. ${ }^{2}$ Critical race feminism proposes a progressive initiative for addressing the inconsistencies embodied within the traditional feminist approaches and is thus suitable for the South African post-apartheid context as it may trigger 'transformative possibilities'. ${ }^{3}$ It is my contention that in order to address the marginalisation of black women, the traditional feminist approaches (such as the dominant feminist approaches) must be done away with for they are a hindrance to legal reform, as they prejudice the very structure they claim to protect.

\section{The different types of distinctions between traditional and critical feminist approaches.}

This essay speaks of feminism in broad legal and philosophical terms. Scholars within the literature relating to feminist theories define feminism as a collection of approaches and ideologies aimed at defining, establishing and defending equal political, economic and social rights for women. ${ }^{4}$ The two general types of feminist approaches will be interrogated below.

\subsection{Traditional feminist approaches}

Traditional feminist approaches are identified as the dominant approaches to feminism. Their goal is primarily aimed at addressing the 'order of gender hierarchy where the female is excluded and

2 K Van Marle \& E Bonthuys 'Feminist theories and concepts' in C Albertyn \& E Bonthuys (eds) Gender, law and justice (2007) 32-37; AC Dailey 'Feminism's Return to Liberation' (1993) 102 The Yale Law Journal at 1274.

3 Y Jooste 'Contemplating a post-apartheid feminist jurisprudence' LLM Thesis, University of Pretoria, 2011 at 1.

$4 \quad$ M Davies 'Asking the law questions' (2008) 213. 
subordinate' to the other. ${ }^{5}$ Van Marle and Bonthuys in their chapter entitled 'Feminist, Theories and Concepts' aptly introduce the different kinds of traditional feminist approaches and these include liberal feminism, Marxist feminism, radical feminism and relational and cultural feminism. The authors argue that these traditional feminist approaches generally accept that society perceives masculine characteristics to be more superior to feminine characteristics. ${ }^{6}$

In particular, liberal feminists dispute that all women show feminist characteristics, and as such, they argue for the removal of gender bias from the law. ${ }^{7}$ The authors argue that liberal feminism places more emphasis on formal rather than substantive equality because the 'approach' only affords certain rights to limited women who share characteristics of the middle class men, to the exclusion of 'feminine' women, the working class of women as well as black women. ${ }^{8}$ Authors against this form of feminist approach argue that the concentration of feminism on the public roles of women does not alleviate the problems such women face in their domestic homes. ${ }^{9}$

On the other hand, Marxist feminism lays the foundation for socialist feminism. Marxist feminists argue that the notion of private property ownership is the root of the subjugation of women in society as private property is exclusive to a man's access. ${ }^{10}$ Socialist feminism adds on to this by pointing out that women are oppressed as a result of patriarchy and the class system. The feminists argue that these systems use sexuality, identity and class to suppress women. ${ }^{11}$

Furthermore, radical feminism perceives the oppression of women as the most fundamental form of oppression, it posits in this instance, that sisterhood transcends barriers of race, class, and culture. $^{12}$ This view will be critically interrogated in this essay. In addition, relational or cultural feminism accept the 'sexualisation of oppositional pairs but reject the hierarchisation', as they accept that women can be defined in terms of their relationships to others but view these relationships as sources of strength and not necessarily ways of encouraging systematic oppression. ${ }^{13}$

Jooste (n 3) 13.

Van Marle \& Bonthuys (n 2) 32.

Van Marle \& Bonthuys (n 2) 33.

8 C MacKinnon 'Difference and dominance: On sex discrimination in Bartlett \& Kennedy' (1993) 102 The Yale Law Journal at 81-85.

9 L Benería \& G Sen 'Class and gender inequalities and women's role in economic development: Theoretical and practical implications' (1982) 8 Feminist Studies at 164-172.

10 Van Marle (n 2) 33.

11 Van Marle (n 2) 33-34.

12 Van Marle (n 2) 35.

13 Van Marle (n 2) 35-36. 
Thus, I detect from the authors' literature that traditional feminist theories turn a blind eye on race and racial classism, which would hierarchise white women above black women and thereby create a system of inequality within the sisterhood umbrella of feminism. ${ }^{14}$ Therefore, traditional feminism fails to conceive the prospect of the need for racial reconciliation and equality between white women and women of colour. Historically, the role of traditional feminist theories was [and still is] to disrupt the gender based hierarchy which places women on the pedestal, subordinate to a masculine and male dominated order. ${ }^{15}$ However, I submit that traditional feminist approaches do not provide a solution for the post1994 South African context and there is need to serve justice to black South African women who have suffered the 'dual-oppression' of both black and white men as well as that of white women.

It is against this background that I strongly recommend South Africa resorts to critical feminist approaches which introduce the fact that the gender subordination of black women does not equate to that of white women and that 'traditional feminist theories do not pay sufficient attention to the racialised experiences of black women'. ${ }^{16}$

\subsection{Critical feminist approaches}

Van Marle and Bonthuys as well as bell hooks introduce critical race feminism, a school of thought which emanates from Critical Race Theory. They argue that critical race feminists criticise traditional feminist theories on four bases:

... it excluded experiences of black women, the issues deemed important are those relevant to white feminist, a shared experience of sisterhood and lastly the alienation of black women and working class women. ${ }^{17}$

Thus, when resorting to critical theories to feminism, matters affecting black women are concurrently addressed within race, class and gender. ${ }^{18}$ On the other hand, classist feminism also recognises the class struggles endured by different women in society. ${ }^{19}$ Simply put, it tells us that the power wanted by white women, was the same they had perceived their men enjoying and that the economic and political privilege enjoyed by white working-class women can never be said to

14 B Hooks Feminism is for everybody: Passionate Politics (2000) 13 \& 55. See also Van Marle (n 2) 32-37; S Liebenberg 'Needs, rights and transformation: adjudicating social rights' (2005) Paper 8 Centre for Human Rights and Global Justice 3.

15 Jooste (n 3) 22.

16 Van Marle (n 2) 40.

17 Van Marle (n 2) 40.

$18 \mathrm{~K}$ Crenshaw 'Mapping the margins: Intersectionality, identity politics and violence against women of colour' in K Crenshaw, N Gotanda, G Peller \& K Thomas (eds) Critical race theory: The key writings that formed the movement (1996) 357. 
be the same for other women in general. This is given further context by critical race feminism, which critically asserts and acknowledges that white women and black women are not in the same hierarchical level, and therefore, black women must fight a battle of 'white supremacy' in this sisterhood umbrella before they fight systems of patriarchy. ${ }^{20}$

\subsection{Distinctions between traditional and critical feminist approaches}

From a review of the literature, one can conclude that the major difference between the traditional and critical feminist approaches is the level of intersection between race, class, gender and sexuality in each approach. ${ }^{21}$ Traditional feminist approaches are primarily focused on the unequal treatment between men and women in general, without copiously intersecting the inequalities existing between women as a result of racial classism. ${ }^{22}$ Such a colour-blind approach does not offer South Africa any possibility for legal transformation or decolonisation because the subject of law would still remain unchanged. ${ }^{23}$ Critical feminism on the other hand, intertwines the subject of race and gender whilst pursuing feminism. ${ }^{24}$ Unlike traditional feminism, critical feminism suggests that the overarching problem for 'equality' in society is not one that can be resolved by merely disrupting heteronormativity and patriarchy, but also unveiling these heteronormative and patriarchal characteristics within the context of race. ${ }^{25}$

Crenshaw argues, that critical feminist theories transcend traditional feminist theories because they not only focus of the subject of gender, but also, the subject of race. ${ }^{26}$ She posits, that ignoring differences (such as racial classism) within groups frustrates the very goal towards equality by traditional feminist approaches. 27 Crenshaw illustrates that many of the experiences women of colour face are not considered within the traditional margins of either race or gender discrimination because the intersection of race and gender

$20 \mathrm{~K}$ Crenshaw 'Demarginalizing the intersection of race and sex: A black feminist critique of antidiscrimination doctrine, feminist theory and antiracist politics' in J James \& TD Sharpley-Whiting (ed) The Black Feminist Reader (2000) 218.

21 M Lugones 'The coloniality of gender' in M Lugones (ed) The Palgrave Handbook of Gender and Development (2016) 1.

22 C Albertyn \& B Goldblatt 'Facing the challenge of transformation: Difficulties in the development of an indigenous jurisprudence of equality' (1998) 14 South African Journal of Human Rights at 251.

23 DA Davis \& S Wildman 'The legacy of doubt: Treatment of sex and race in the HillThomas Hearings' in AK Wing (ed) Critical Race Feminism a Reader (1997) at 175.

24 Crenshaw (n 18) 357.

25 S Jackson 'Why a materialist feminism is (still) possible and necessary' (2001) 24 Women's Studies International Forum at 283.

26 Crenshaw (n 18) 357.

27 Crenshaw (n 18) 357. 
'factors into black women's lives in ways that cannot be captured wholly by looking at the women race or gender dimensions of those experiences separately'.28

It is against this backdrop that I detect whether critical feminist approaches would offer any prospects towards transformation or decolonisation in the subject of jurisprudence and the law in a post1994 South African context. I shall now resort to ponder upon and develop the meaning of transformation and decolonisation within the context of legal philosophy in post-1994 South Africa.

\subsubsection{Transformation}

Cornell defines transformation as "change radical enough to so dramatically restructure any system - be it is political, legal, or social - that the identity of the system is itself altered'. ${ }^{29}$ Similarly, the Education White Paper 3 provides that transformation '... requires that all existing practices, institutions and values are viewed anew and rethought in terms of their fitness for the new era'. 30

Transformation is based on the need to change South Africa into a democratic state grounded on human dignity, equality and freedom. ${ }^{31}$ Focal to the issue of transformation is the realisation of social justice and socio-economic equality across all races and genders because the Constitution mandates transformation that results in substantive equality and not some mere 'formal' change. ${ }^{32}$ Van Marle therefore contends, that an interpretation that aims to achieve transformative constitutionalism is necessary as it would engage deeply with the pre and post-1994 South African contexts in adjudication and aim towards achieving a substantive change of the status quo in which black South African women find themselves. ${ }^{33}$ Here, she suggests that in order to transform as a society, we need to advocate for critical theories of law and follow a critical approach to transformative adjudication by accepting and acknowledging canons of indeterminacy of the law. ${ }^{34}$ After all;

Law is simply politics dressed up in a different garb, it neither operates in a historical vacuum nor does it exist independently of ideological

28 Crenshaw (n 18) 358.

29 FM Githuru 'Transformative constitutionalism, legal culture and the judiciary under the 2010 Constitution of Kenya' LLD thesis, University of Pretoria, 2015 at 91.

30 RJ Trunette 'Decolonising the Curriculum, transforming the University: A discursive perspective' DUT 4. 03 March 2017 https://www.dut.ac.za/wpcontent/uploads/2017/03/T-JOSEPH.pdf (accessed 27 May 2019).

31 Githuru (n 29) 174

$32 M$ Wesson \& $M$ Du Plessis 'Fifteen years on: central issues relating to the transformation of the South African judiciary' (2008) 24 SAJHR at 200.

33 Wesson \& Du Plessis (n 32) 191.

34 D Dyzenhaus 'Law as a justification; Etienne Mureinik's conception of legal culture' (1998) 14 SAJHR at 29. 
struggles in society. Legal doctrine not only does not, but also cannot, generate determinate results in concrete cases... legal doctrine can be manipulated to justify an almost infinite spectrum of possible outcomes. ${ }^{35}$

Critical feminist theories offer transformative possibilities to the law to integrate an appreciation of the intersection of race and gender realities. ${ }^{36}$ This can be done through legal processes of altering substantive law to retort to black women's needs. ${ }^{37}$ It is on this note that it must be made clear, that critical feminist theories find their roots in Critical Legal Studies (CLS), which places specific focus on history to find answers to current transformation issues in South Africa. ${ }^{38}$ Adherents of the CLS place indeterminacy as being central to the law and legal rules. ${ }^{39}$ This gap of 'indeterminacy' of the law means that legal norms are not capable of a 'stable and preordained meaning'. 40 This further entails that judges have to give meaning to legal norms and provisions because laws themselves cannot determine the meaning of their own provisions. It is against this reality that the courts should lean on critical feminist theories when addressing issues affecting black women, in order to bring about transformation in the law and jurisprudence. This kind of approach taken by the courts would be reflective of Klare's interpretation of transformative constitutionalism, which requires judges to adjudicate by using not only novel legal norms of this constitutional egalitarianism but even more so, new adjudicative methods as required by our new legal paradigm. ${ }^{41}$

To my mind, this way of applying the law will change the way in which the law is taught as a subject in legal education as it would mark a shift from the 'law teacher' teaching the law in a conservative and determinate way, to teaching the law 'in a manner that [seeks] to prepare students for critical application of legal doctrines'. 42 This requires law teachers to stop teaching law as a coherent body of legal norms but present the law with its fragmented, pluralist, inconsistent and habitually contradictory prerogatives to authority that accumulatively make the subject of law. ${ }^{43}$ In my view, this means, when teaching Feminist Jurisprudence as a subject of law,

35 A Hutchinson \& P Monahan 'Law, politics and critical legal scholars: the unfolding drama of American legal thought' (1984) Stanford Law Review at 206.

36 Crenshaw (n 18) 371. See also N Giffney 'Introduction: The ' $q$ ' word' in N Giffney (ed) The Ashgate Companion to Queer Theory (2009) 1 -13.

37 Crenshaw (n 18) 371.

38 WB le Roux \& K van Marle 'Critical legal studies' in C Roederer \& D Moellendorf (eds) Jurisprudence (2004) 246-247.

39 D Kennedy 'Form and substance in private law adjudication' (1976) 89 Harvard Law Review at 1685.

40 As above.

41 G Quinot 'Transformative legal education' (2011) Stellenbosch Law Review at 6.

42 T Madlingozi 'Legal academics and progressive politics in South Africa: Moving beyond the ivory tower' (2006) Pulp Fictions at 17

43 Quinot (n 41) 8. 
elaboration must not only be placed on the centralised gender theme, but the different categories that persist within the gender itself (such as race and class). By espousing this kind of pedagogy, we shall have the ability to imbue a transformed subject of law as instructed by our Constitution. ${ }^{44}$ It is based on this trail of thought that I believe that such transformation in legal education would lead to its decolonisation thereof.

Essentially, the Constitution seeks to achieve substantive equality through transformative constitutionalism which seeks to cater for and resolve societal and economic disparities, inequality and matters of subordination which may exist in society. ${ }^{45}$ Thus, to achieve this substantive equality, Westen tells us that:

the law is required to take into account the varied circumstances of individuals which need special attention to ensure a favourable outcome to all. The Constitutional Court emphasized this in National Coalition for Gay and Lesbian Equality \& Another $v$ Minister of Justice \& others. ${ }^{46}$ It stated that the idea of substantive equality takes into account the social and economic conditions of individuals and historically disadvantaged groups in society, and that even though we are each different, unique, and with various talents, law in the Constitution ought to be utilized to mitigate the adverse effects of such inherent differences. This is opposed to formal equality which simply connotes sameness, equal, or similar treatment of all people. It requires the law to treat people in the same manner irrespective of circumstances that they may find themselves in. ${ }^{47}$

\subsubsection{Decolonisation}

There is a rich pool of definitions regarding decolonisation in literature review. Scholars such as Le Grange contend that decolonisation is a response to the first and second generation of colonialism, the first being that of colonising by conquering physical spaces and individuals, the second being the colonisation of the mind through disciplines such as education and law. ${ }^{48}$

The transformation spoken of above, will lead to a process of decoloniality in the law and jurisprudence. I must admit, that the process of decoloniality will not be achieved overnight as 'it will be a protracted struggle'. ${ }^{49}$ Trunette in particular, posits that this is because the majority of academic staff in South African Universities are not prepared to initiate a decoloniality transformation process as

44 As above.

45 P Langa 'Transformative constitutionalism' (2008) Stellenbosch LR at 351.

46 National Coalition for Gay and Lesbian Equality \& Another v Minister of Justice \& others 1999 (1) SA 6 (CC) [60] to [62].

47 P Westen 'The empty idea of equality' (1982) Harvard Law Review at 555-596.

48 Trunette (n 30) 6.

49 As above. 
they themselves are products of coloniality. ${ }^{50}$ Thus, in as much as we live in a 'postcolonial' South Africa, the law and jurisprudence are still colonised. Such 'post-coloniality' is presented by virtue of the fact that colonial administrations have been eliminated from government structures. ${ }^{51}$ It is against this background that colonial forms of domination such as traditional feminist approaches which cater (almost exclusively) for the needs of white women continue even after the end of colonial administrations. ${ }^{52}$ It is through applying CLS that issues of coloniality and transformation can be effectively addressed. 53

Literature reveals, that traditional feminist approaches have been criticised for ignoring women from minority groups who have their own separate and special experiences. ${ }^{54}$ Thus, it must not be ignored that it may be argued by traditional feminists that, given the South African context where black women form the majority of the female population and specifically outnumber white women, critical feminism is not relevant because black women's struggles are not silenced in the hands of the majority's race. ${ }^{55}$ They may argue, that the critical approach to feminism focuses on race at the expense of the equality of sexes. ${ }^{56}$ However, it is important to contextualise the present time with the South African history in which blacks and whites existed in hierarchical levels, with the white person seen as superior, and the black person seen as inferior. It is my contention that in fact, this incongruous view particularly still exists in South Africa. It is in light of this that we must understand that critical feminism works to address the intersectionality of race and gender simultaneously, even if race is rightfully placed at the centre of the paradigm. ${ }^{57}$

Therefore, I advocate for the application of CLS which provides us with useful theoretical constructs for transformation and decoloniality, by explaining how traditional approaches to social concepts not only perpetuate colonialism, but also maintain racism and Eurocentric epistemologies. ${ }^{58}$ It is against this backdrop that I posit that race as a social construct has not been sufficiently dealt with in post-apartheid South Africa and our generation should work to rectify this omission. Trunette makes clear that 'race is a social construct matter and as such, cannot be swept under the rug when

50 Trunette (n 30) 6. See also K Wiredu 'Conceptual decolonization as an imperative in contemporary African philosophy’ (2002) 35 Rue Descartes at 53-64.

51 Trunette (n 30) 7.

52 As above.

53 Trunette (n 30) 8.

54 B Smith 'Intersectional discrimination and substantive equality: A comparative and theoretical perspective' (2016) 16 The Equal Rights Review at 73.

55 Hooks (n 14) 13.

56 Hooks (n 14) 55.

57 Trunette (n 30) 11.

58 Trunette (n 30) 10. 
theorising about gender injustices'. ${ }^{59}$ It is critical theories that can serve as the way through which black womens' subaltern voices are heard by focusing on the intersectionality between race, gender and classism. ${ }^{60}$ Critical feminism challenges whiteness as a norm and those who claim that traditional feminism is 'neutral and objective'. ${ }^{61}$ Transformation and decolonisation of the law and jurisprudence challenge exactly this claim of neutrality, objectivity and colour-blindness to white privilege. ${ }^{62}$

As aforementioned, introducing a critical way of thinking about the law and jurisprudence will eventually lead to changes in terms of which the law is taught in legal education. It is perhaps plausible to assume that this change would thus lead to decolonising legal education itself. The decolonisation of legal education entails initially decolonising the curriculum and subsequently, the university and the higher education landscape. ${ }^{63}$

\section{What effect does the traditional feminist approach have on the constitutional imperative to equality, and what impact does it have on the philosophy of jurisprudence and its transformation thereof?}

Traditional feminist approaches encumber the constitutional imperative to substantive equality because it is primarily aimed at a formalistic kind of equality. ${ }^{64}$ It does not allow for transformation to occur and thus restricts the decolonisation of jurisprudence and the law in general. ${ }^{65}$ To illustrate how 'ineffective' traditional approaches are to the discourse of transformation and decolonisation, I will journey into a discussion that shows that traditional approaches such as restricted jurisprudence in particular, burden the discourse on transformation and decolonisation, whereas general jurisprudence presents us with the possibilities of transforming and decolonising the study of law and jurisprudence. ${ }^{66}$

59 As above.

60 Crenshaw (n 18) 357 - 371.

61 C Douzinas \& A Geary Critical jurisprudence: The political philosophy of justice (2005) 259.

62 P Nyawo 'A critical race feminist perspective on section 217 of the Constitution' LLM Thesis, University of Pretoria, 2013 at 37.

63 Trunette (n 30) 11.

64 KE Klare 'Legal culture and transformative constitutionalism' (1998) 14 SAJHR at 146.

65 Githuru (n 29) 23.

66 As above. 
For purposes of this illustration, restricted jurisprudence must be seen as traditional feminism and general jurisprudence must be seen as critical feminism. Restricted jurisprudence follows a dominated approach of thinking focusing on a restricted way of defining and delimiting what properly construes 'pure' law and distinguishing it with other disciplines. ${ }^{67}$ Here, the act of determining what the law is, is aimed at restricting what lawyers can do and look at. ${ }^{68}$ This results in the deterioration of the discipline of law because it limits the application of the law as the law becomes 'a science with predetermined formulas'. ${ }^{69}$ In other words, a mere study of legal norms with no critical understanding and engagement between the law and the social context in which it applies. ${ }^{70}$ The law is applied in a narrow way which is detached from historical context and societal implications. Similarly, traditional feminism follows a narrow approach of thinking restricted to the central theme of gender, without any considerations of historical context and issues of race and classism.

On the other hand, general jurisprudence can be explained as returning to the classical inquiry of jurisprudential philosophy. ${ }^{71}$ Adopting a broader meaning of what 'law' entails, while examining 'legal aspects of social reproduction both within and without state of law'. ${ }^{72}$ This means that general jurisprudence takes into account all aspects that make a societal structure including politics, philosophy, economics as well as emotional and physical modes of production and reproduction. ${ }^{73}$ General jurisprudence is the legal interzone which concerns itself with intersectional issues between legal texts and the social world. ${ }^{74}$ Similarly, critical feminism can be regarded as the legal interzone that places focus of the intersectionality between race, gender and classism. ${ }^{75}$ It is based on this trail of thought that one can perceive that a general and critical way of thinking may promote possibilities of transformation and decolonisation in legal philosophy, in particular, the law and jurisprudence.

When following general jurisprudence, the way in which the law is taught is not limited to teaching it in the colonial language of English. ${ }^{76}$ General jurisprudence allows us to use the law in order to transcend coloniality. This can be done by reassuring the use of indigenous dialects in academic contexts while correspondingly

67 Douzinas \& Geary (n 61) 6.

68 Douzinas \& Geary (n 61) 259.

69 Douzinas \& Geary (n 61) 6

70 Douzinas \& Geary (n 61) 259 J Murungi An introduction to African legal philosophy (2013) 32.

71 Douzinas \& Geary (n 61) 10.

72 Douzinas \& Geary (n 61) 11.

73 As above.

74 Douzinas \& Geary (n 61) 12.

75 Crenshaw (n 18) 360.

76 Douzinas \& Geary (n 61)259. 
enhancing multilingualism. Since societal implications are taken into account here, this encourages the law not to be applied in a vacuum but with proper considerations of its impact on society - thus making the law 'fluid' and indeterminate. This indeterminacy offers the law the prospect to be applied in favour of transformation and decolonisation. ${ }^{77}$ My argument here is that, in order to capitalise on the possibility of transformation and decolonisation, the law must be read and interpreted in a critical way. In addition, this would be in line with the concept of transformative constitutionalism. Van Marle posits, that to term something transformative means to advocate a disruption in the traditional connection with law in solitude and traverse other disciplines. ${ }^{78}$ A major purpose of transformative constitutionalism continues to be the need for change and the healing of wounds and divisions of the past [and recurring] injustices in South Africa. ${ }^{79}$ Notably, one of the largest challenges towards transformation in South Africa remains the racial differences which effectively contribute towards the creation of social and economic gaps. $^{80}$

Klare notes that in South Africa, we are challenged and limited by a conservative approach to legal culture and this kind of approach is resistant to change and is largely formalistic thus, obscuring the attainment of social justice and substantive equality under the law. ${ }^{81}$ In order to attain substantive legal change and to overcome these limitations of legal norms, the law must mature away from the formalistic approach (traditional feminist approaches), it must be capable of breaking down the walls of this formalistic and conservative legal approach when circumstances so demand and necessitate. ${ }^{82}$

\section{How to resolve the conflict between race and gender struggles of black women?}

In a post-1994 South African context, issues of feminism cannot be addressed by solely placing focus on gender but the intersectionality between inter alia, race, gender, classism, must also be looked at. Thus, perhaps to reconcile the conflict of black womens' struggle of race and gender, it is plausible to lean on critical feminism which addresses both the issue of race and gender simultaneously. ${ }^{83}$ This is

Kennedy (n 39) 1685.

Githuru (n 29) 19.

Githuru (n 29) 3.

Githuru (n 29) 17.

Klare (n 64) 150.

Langa (n 45) 357-358.

Crenshaw (n 18) 360; D Bell 'Who's afraid of critical race theory' (1995) 4 University of Illinois Law Review 893 - 910. 
primarily because reliance on traditional feminism would not sufficiently and effectively address the prejudices faced by black women in society. ${ }^{84}$ As such, it is my suggestion that this 'sisterhoodfeminism' umbrella finds dysfunctionality in a society like South Africa, where the reality of racism still systematically exists and black and white women cannot be said to have the same 'women' struggles. 85

I am of the opinion that critical feminism is indeed the unattended call to which South Africa needs to answer, in order to address challenges it faces in respect of women and their position in society. I do not favour the traditional feminist approach because it does not address the idea of the inescapable and inherent racism in our 'postapartheid' South African context. ${ }^{86}$ I believe that a person's perception and experience of the world is indispensably determined by their life experiences, one of these being their position in the race structure of a society. Thus, an approach which has focal attention on both race and gender 'kills two birds with one stone', by addressing both issues of racial classism as well as gender equality. ${ }^{87}$

Furthermore, I posit that generally, in order to achieve this reconciliation, transformation must be capable of providing a persistent platform open to discussion and the changing demands of society as aptly captured by Langa when he says:

transformation is not a temporary phenomenon that ends when we all have equal access to resources and basic services and when lawyers and judges embrace a culture of justification ... permanent idea l... in which change is unpredictable but the idea of change is constant... sees the Constitution as not transformative because of its peculiar historical position or its particular socio-economic goals but because it envisions a society that will always be open to change and contestation, a society that will always be defined by transformation ... ${ }^{88}$

I submit, that in view of the fact that South Africa has not recovered and is still crippled by the unfinished and unsettled business of a colonial apartheid past, critical approaches to the law and jurisprudence in general, may provide reform to the current social and economic impasse. It is without doubt that in order to realise and achieve this reconciliation, transformation and decolonisation, we are required to engage with CLS on the subject of legal culture, education and philosophy. ${ }^{89}$ 


\section{Conclusion}

In this paper I have interrogated the post-apartheid feminist approaches to jurisprudential discourse by considering whether critical feminist approaches contribute in transforming or decolonising South African law and jurisprudence. I conclusively suggest that the inquiry to address 'gender equality' before and without addressing issues of racism and racial classism simultaneously in South Africa contributes effectively to the continued marginalisation of black women. As such, my position attempts to encourage that we engage with the critical feminist approaches in order to address the prejudices that traditional feminist approaches have on black women and to enhance possibilities of transforming and decolonising the law and jurisprudence in South Africa. 


\section{SUBALTERN RESPONSES TO EPISTEMIC VIOLENCE; THE LEGACY OF COLONIALISM}
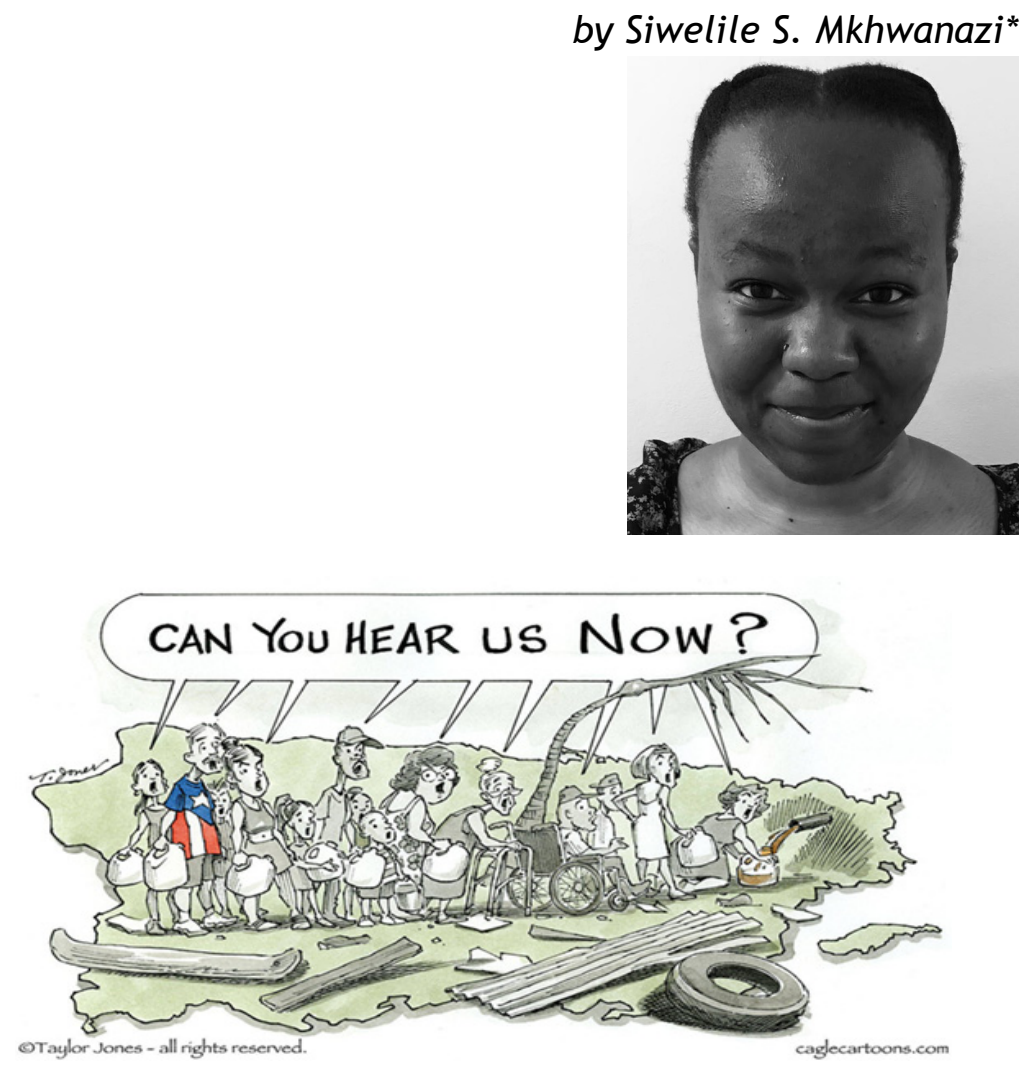

Figure 1: Cartoon by Taylor Jones ${ }^{1}$

* $\quad$ Final year LLB student, University of Pretoria. Vice Chairperson of Legal Shebeen and recipient of the Norton Rose Fulbright South Africa Bursary. This article deals with the contentious issue of epistemic violence in the legal culture, and the rift between the academic and the marginalised classes that the law purports to support. It challenges legal thinkers to engage in issues surrounding race, sex/ gender, and class and to reflect on these issues in order to make sense of South Africa's norms and values and develop a critical jurisprudence. Special thanks go to Akhona Mdunge who dared me to put my thoughts down on paper, Tshireletso Kuriti, and Victor Radebe, whose criticism about Marxism and the class divide system informs a huge portion of this paper. I dedicate this article to my brothers, Nhlakanipho Mkhwanazi and Malusi Khathwayo who are both always challenging me to be cognisant of the law's lived reality. This publication would not have been possible without the kind yet stern words of the PSLR Editor-in-Chief Miss Primrose E.R Karusha. To her, I would like to extend the most heartfelt thank you

1 In this cartoon for eaglecartoons.com, Taylor Jones illustrates how the marginalised in society such as the poor, the elderly, and the disabled are pushed further into the outskirts of society, while enjoying only the bare minimum of the 


\section{1 introduction}

Epistemic violence is the extent in which local knowledge has been ignored, rejected and in some cases completely wiped out. ${ }^{2}$ It stems from a constant repression that imposes mental violence rather than physical violence. This cognitive abuse is instigated and institutionalised by a coloniser, who sees himself as superior and limits the 'subordinate's' happiness by burdening their knowledge of freedom. ${ }^{3}$

This field of violence is portrayed throughout South African history, which is commonly signified by the arrival of Jan Van Riebeek in the Cape of Good Hope. Vale is perpetually mesmerised by the nature in which ideas, as a result of this, were carried from different corners of the world into South Africa, but in stark contrast, that very same South Africa is now often portrayed as a 'one-dimensional South Africa' as a result of epistemic violence. ${ }^{4}$ In order to redress the past and contribute to epistemic diversity and justice, one must have a sufficient grasp of the systemic integration of western knowledge into South Africa, and this serves as a direct example of epistemic violence. The real questions that must be asked are; first, how Western intellectual history has contributed to epistemic violence in South Africa, for example through positivism, which removed morality from law and therefore instilled the oppression of the apartheid regime; second, how we may make use of some parts of this intellectual history to respond to epistemic violence, for example, by using Black Consciousness to advocate for epistemic diversity. ${ }^{5}$

This essay aims to use critical jurisprudence as a tool to listen to the different voices and perspectives excluded by the traditional mainstream, without assimilating them. It also aims to engage with and reflect on the abovementioned theme of epistemic violence, and reflect on how critical legal theories could assist in the development of a critical jurisprudence. It will draw inspiration from SleeperBlack, an artwork by William Kentridge showing the discomfort of ignorance.

2 state resources. It further highlights how their voice has been stifled, with the phrase 'can you hear us now?' often used in bad telephone reception to demonstrate how the 'subalterns' have been speaking, but they have not been heard.

$2 \mathrm{~T}$ Thomas What is epistemological violence in the empirical social sciences? Social and personality psychology compass (2010) 2.

3 As Above.

$4 \quad \mathrm{P}$ Vale 'Of ships, bedraggled crews and the miscegenation of ideas: interpreting intellectual traditions in South Africa' in P Vale, L Hamilton \& EH Prinsloo (eds) Intellectual traditions in South Africa. Ideas, individuals and institutions (2014) 5.

5 J Modiri "The jurisprudence of Steve Biko: A study in race, law and power in the "afterlife" of colonial-apartheid' PhD thesis, University of Pretoria, 2017 at 287. 


\section{Intellectual history as a response to epistemic violence}

In order to make sense of the extent to which traditional knowledge or perspectives that were deemed inferior were ignored and rejected, one must trace the various intellectual histories that became prominent in the country, and the resistance against these traditional approaches. This exercise compels us to recognise, not only the legal theory and jurisprudence that was prominent in South Africa from 1652 until present, but to also consider the changes that have contributed to that legal theory that arose before the colonisers 'came in different boats onto the Cape of Good Hope' as Vale declares. ${ }^{6}$ Vale further asserts that; 'every conversation on intellectual traditions in South Africa must deal with the fact that both the idea of it, and the country itself, were construed from the outside in.'7 It would be a futile attempt to deconstruct the legal jurisprudence introduced in South Africa without recognising that it is itself multi-faceted and is influenced by the Roman-Dutch law, English law and the newly legitimised customary laws, which are in turn, influenced by a wide array of intellectual theories such as Marxism, feminism, legal pluralism and the Black Consciousness movement, which led to a miscegenation or mixing of ideas, but due to epistemic violence, only a select few became prominent. The words of Russell Ferguson highlight the extent of epistemic violence and describes the relationship between the academic and the marginalised classes:

[There is] no need to hear your voice, when I can talk about you better than you can speak about yourself. No need to hear your voice. Only tell me about your pain. I want to know your story. And then I will tell it back to you in a new way. Tell it back to you in such a way that it has become mine, my own. Re-writing you, I write myself anew. I am still author, authority. I am still [the] colonizer, the speaking subject, and you are now at the centre of my talk. ${ }^{8}$

However, early modern historian Fernando Coronil declared that the goal of an investigator must not be to ascend to a position of dominance over the voice, by interpreting its words to the meanings we desire to attribute to them but 'to listen to the subaltern subjects, and to engage them and interact with their voices." Douzinas and Gearey asserts that modern jurisprudence has neglected the big philosophical questions offered by natural law and that this omission

6 As above.

7 Vale (n 4) 7.

$8 \mathrm{H}$ Bell 'Marginality as a site of resistance' in R Ferguson (eds) Out there: marginalization and contemporary cultures (1990) 241.

9 F Coronil 'Listening to the subaltern: the poetics of neo-colonial states' (1994) 4 Poetics Today at 645. 
has 'seriously affected the integrity of the discipline., 10 Such a shift has been highlighted by various legal theories such as Marxism, which attacks capitalism and declares that it enables social discrepancies between the rich and the poor where the bourgeoisie enjoy the fruits of the subordinate class' labour and exploit them by using laws and policy. ${ }^{11}$ The rich bourgeoisie, according to Karl Marx, dehumanised the subordinate class and reduced their relationship between power and knowledge in scholarly and popular thinking. ${ }^{12}$ Without power, one's voice was reduced to silence. Veitch stated that, 'there is a connection between material production and the control of intellectual production. ${ }^{13}$ This link between class and intellectual production is a philosophical influence in the South African fight against white monopoly capital and the recent Afrikaans Must Fall campaign. ${ }^{14}$ White monopoly capital is a residue of apartheid and shows that the economy is still owned by the oppressors, especially the 'white Afrikaner male' and Afrikaans as a medium of instruction in institutions is seen as perpetuating cultural supremacy and further enabling epistemic violence.

This racial divide along class lines seems to be enabled by capitalism and the crux of what Marx denounces is that, under capitalistic conditions of production, the white bourgeoise ruling class owns the means of production, the surplus value of the produce and the government. ${ }^{15}$ Douzinas and Gearey declare that, 'power relations and practices penetrate into the social and often takes a variable legal form.'16 Furthermore, Foucault's theory of legal modernity states that governmentality is a specific form of power, which does not necessarily emanate from the state. ${ }^{17}$ The author further argues, that 'power is not located at a particular point in society, it cannot be possessed nor is it a consequence of the ownership of something; such as the means of production.'18 This theory negates the assertion that the white bourgeoisie has power, or should have power in society merely because they own the means to production. It also raises radical questions about the law's role and function in modern society.

Foucault's theory gives a possibility for epistemic diversity and allows us to listen to and acquire knowledge and ideas that had been

C Douzinas \& A Gearey Critical jurisprudence: The political philosophy of justice (2005) 11.

11 Douzinas \& Gearey (n 10) 11.

12 As above.

13 S Veitch et al Jurisprudence: themes and concepts (2012) 233.

14 See Afriforum $v$ University of the Free State 2018 (2) SA 185 (CC) para 2 for an illustration of colonial-settler domination and the link between language and dominance.

15 Douzinas \& Gearey (n 10) 12.

16 Douzinas \& Gearey (n 10) 9.

17 Veitch (n 13) 241.

18 As above. 
previously silenced by the sovereign or juridical power of the state. The traditional juridical model of power enables the sovereign state to make and pass regulatory laws that society is invariably bound to, without taking into cognisance the social reality. ${ }^{19}$ It made use of hierarchical observation and examination in order to enforce the discipline of individuals in society through coercion and punishment. However, the normalising power of the modern liberal state allows for individual autonomy and gives that text-law is often distracted from the real operation of power in society. ${ }^{20}$ According to this view, law ceases to be a principle of power or a yardstick with which society measures itself against, but becomes a guideline for harmonious living. Morality and moral philosophy are thus correctly acknowledged as an inherent part of judicial hermeneutics. Such an assertion makes provision for epistemic philosophy and self-governance to come to the fore, and enables the resolution of certain disputes to be handled outside of the state's iron fist.

\section{The possibility for epistemic diversity and ultimately epistemic justice}

Foucault's theory of legal modernity links with Karl Klare's transformative adjudication and legal culture, which allows adjudicators to listen to perspectives previously excluded by parliamentary sovereignty. ${ }^{21}$ This is done by allowing judges to voice their intellectual sensibilities and acknowledge that they exist. ${ }^{22}$ Klare stated that the exclusion of personal or political values called for by the traditional rule-of-law is simply impossible. ${ }^{23}$ Reflecting is essential for the future health of the society, economy and polity within South Africa and this is what transformative constitutionalism seeks to achieve. 24 Moreover, the Constitution celebrates multiculturalism and diversity. ${ }^{25}$ The preamble expressly acknowledges the scars of the deeply divisive South African past and declares a determination to bridge the gap between the past and a future of democracy and constitutionalism. The South African constitution offers the perfect platform for epistemic diversity and justice and is essential for the development of a critical jurisprudence.

21 K Klare 'Legal culture and transformative constitutionalism' (1998) 14 South African Journal of Human Rights at 157.

22 Klare (n 21) 166.

23 Klare (n 21) 163.

24 P Langa 'Transformative Constitutionalism' (2006) 17(3) Stellenbosch Law Review at 352 .

25 The Preamble of the Constitution of the Republic of South Africa, 1996. 
In the Constitutional Court art gallery, amongst others, is an art piece by William Kentridge called Sleeper - Black, telling the story of unblissful ignorance. It portrays the desire to remain oblivious to reality and to history, it was produced as part of the film project called Ubu tells the truth which highlights the different forms of selfawareness, as defined by a rift between the public and private self. ${ }^{26}$ The main protagonist of this film is a camera on a tripod, which sees everything and then uses its knowledge to try to wipe out noncorroborating witnesses. Characters in the film are locked in a constant state of denial, specifically over the exploitation and abuse of African people spanning from colonialism to apartheid. However, in the end they experience a 'rude and painful awakening' and start acknowledging the past, and their present reality. According to Klare, denial 'obscures the possibility, and therefore the desirability for social change. 27 It is when we acknowledge the past, in all its atrocious glory, that we can have an honest perspective of the present social reality.

One of the intellectual traditions that enables us to reflect on the past is the Black Consciousness Movement. According to More, this movement is essentially 'a black political thought that is part of a long line of black activism and philosophical thought dating back to the advent of African slavery, colonialism, anti-black racism and the modern world. ${ }^{28}$ Its focus is black resistance to white racism and white supremacy, and is both a movement and a philosophy. Robert Sobukwe's description of the Black Consciousness philosophy is the understanding of the black people's desire to construct their own identity and take full responsibility of their own liberation. ${ }^{29}$ The movement is not shy to acknowledge the gross inhumane atrocities of colonialism, and the existential crisis of black people who were held hostage in their own land. Aimé Césaire articulated in an interview that, the result of being black in a white-owned world was that, you 'lived in an atmosphere of rejection for so long, you develop an inferiority complex. 30 This is a result of the cognitive abuse colonialism had on the identity and humanity of the indigenous people.

However, this philosophy does not aim to only acknowledge and delve into the past. It also aims to reclaim black identity and petitions for the decolonisation of institutions and the human mind through self-consciousness and self-definition. This is a reflection of a famous

YoutubeZA, 'Ubu tells the truth (Ubú cuenta la verdad 1997)' 9 June 2014 https:/ /www.youtube.com/watch?v=cVWh_kYD2GY (accessed 30 March 2018). Klare (n 21) 166

28 MP More 'The intellectual foundations of the Black Consciousness Movement' in P Vale; L Hamilton \& EH Prinsloo (eds) Intellectual traditions in South Africa. Ideas, individuals and institutions 176. 
quote by Antonio Gramsci, an Italian Marxist philosopher. He claims that Man is a product of history and He has only been 'able to acquire a sense of worth bit by bit, in one sector of society after another through intellectual reasoning, and not out of brute physiological needs.' 31 This highlights the importance of epistemology, and intellectual perspective, because although historical and political events in South Africa are important, thinking about how politics and history emerge in the minds of people and society may matter more. Black Consciousness is an affirmation of the struggle for justice, not just physical justice but epistemic justice as well. The history and freedom of Man is very much linked to his ability to conceive of ideas and have them heard, as the Latin philosophical saying goes " think, therefore I am.' 32 By refusing individuals the chance to have their ideas and perspective heard, we attack their humanity and in essence dehumanise them.

Although the Black Consciousness movement is influenced by a continuity of ideas from Negritude to black theology, black theology and the Black Consciousness Movement weren't always aligned since most Black Consciousness advocates, Biko included, were adamant that the religion was used to distract black people from what was truly going on, which is colonialism. Steve Biko outlined his critique on Christianity by saying, "it was too passive in dealing with oppression, too bureaucratic, and too accepting of the status quo.'33 It is often said that our ancestors traded the land for a bible and a suit. However, in the 1960s it became clear that Black Consciousness had to be connected to black theology so that it does not become an obstacle to liberation.

\section{The development of a critical jurisprudence}

The advent of globalisation has refocused the attention on plural forms of legal ordering and has reintroduced the notion of legal pluralism. This legal theory itself takes various forms and can be used to redress the adverse effects of epistemic violence by reintroducing knowledge and dispute resolution measures that have been previously excluded and shunned. Veitch argues that indigenous forms of law did not disappear in the colonial state, and that there was a co-existence

31 WF Felice Taking suffering seriously: the importance of collective human rights (1996) 147.

32 Translated into English by Rene Descartes.

33 A Egan 'Christianity as an intellectual tradition in South Africa: Les Trahisons des clercs' in P Vale; L Hamilton \& EH Prinsloo (eds) Intellectual traditions in South Africa. Ideas, individuals and institutions (2014) 251. 
between formal and indigenous law, the latter of which was unfortunately dispensed when inconvenient. ${ }^{34}$

Veitch talks about John Griffith's distinction between 'strong' and 'weak' legal pluralism and argues that the latter is not a true reflection of legal pluralism since its legitimisation is subject to 'formal acquiescence by the state.' ${ }^{5}$ Therefore, it becomes problematic where indigenous law is ignored and not recognised by the state despite the social reality. This mitigates the legal tradition's fight against epistemic violence, as it highlights a very restricted interpretation of jurisprudence. As Douzinas and Gearey highlighted, such jurisprudence excludes all matter that does not belong to state law and 'addresses a restricted part of legality's role in social being. ' 36 John Griffith argues, that 'state law is but one legal order, whose authorisation is unnecessary for the empirical operation of other forms of law.' 37 The distinction between 'strong' and 'weak' legal pluralism is controversial but the leading account of it is held by Boaventura de Sousa Santos. ${ }^{38}$ He advocates for structural places in society that generate their distinct forms of law, outside the state. ${ }^{39}$ He famously asserts that the actual legal rules that apply at any given time are a combination of both state law and legal norms in the different social structures. ${ }^{40}$ The recognition of these legal and social norms would immensely contribute towards epistemic diversity and justice. Empirical approaches to legal pluralism aim to provide a more comprehensible account of the actual norms that influence everyday life and demand a more in-depth research into the social being outside of state-law.

Discussions on epistemic diversity and justice would be incomplete without acknowledging the effects that a lack of it has had on females in society. It cannot be argued that women's history, work and cultural contributions have been ignored or erased for centuries. The post-1994 dispensation boasts equality, not only racial equality, but gender equality as well. However, although women are now numerically well presented in government and their active contribution in the struggle against apartheid is acknowledged, they are still heavily oppressed and marginalised in society. There is still a large number of reported and unreported cases of rape and domestic

34 Veitch (n 13) 209.

35 Veitch (n 13) 210.

36 Douzinas \& Gearey (n 10) 17.

37 Veitch (n 13) 210.

38 Professor at the School of Economics at the University of Coimbra.

39 B Santos 'The law of the oppressed: the construction and reproduction of legality in Pasargada.' (1977) 12 Law \& Society Review at 14.

40 As above. 
violence against women. ${ }^{41}$ The mere presence and participation of women in public activity does not negate this social reality. Women were given soft liberal rights without challenging, criticising and dismantling patriarchal social structures. South African gender never got the attention that race received as, 'the struggle for political revolution came first and women were expressly told that their demands for equality had to wait in the queue.' 42

One of the challenges in tracking feminism in South African intellectual thinking, according to Helen Moffett, is 'the lack of clarity about what this term encompasses." 43 There are multiple forms of feminisms and different schools of feminist thoughts, which may be divided amongst class and racial lines, but what they all have in common is their attack against patriarchy and male dominance in society. However, 'feminist conceptions of justice are often seen as Western or imperialist even though many feminists still struggle to find theoretical and practical examples that include non-Western women.' 44 The theoretical aim of this legal theory is to listen to these non-Western perspectives of feminism without assimilating them.

\section{Conclusion}

This essay has reflected on how we can use intellectual history as a tool to foster epistemic diversity. It has also used critical legal theories such as feminism, which highlighted the role of gender equality in society in order to listen to previously excluded profeminist voices. Marxism was also used to highlight the relationship between class, power and law, drawing from Foucault's theory of legal modernity. After a critical analysis of these theories, I hereby infer that, like transformation, the development of a critical jurisprudence will never be a finished work. It should be rather viewed as an ongoing exercise that is enabled by the critical legal theories concerned with race, sex/gender, and class and so on. We must reflect on these in order to make sense of South Africa's norms

41 According to StatsSA, the South African police recorded 41,583 rapes in 2018/19; these statistics can be found at http://www.statssa.gov.za/publications/P0341/ P03412018.pdf (accessed 19 October 2019). However, the police's rape statistics should not been viewed as an accurate measure of the extent of this crime since there is still a large number of unreported rape cases according to the Institute for Security Studies at https://issafrica.org/research/policy-brief/rape-andother-forms-of-sexual-violence-in south-africa (accessed 19 October 2019). There is, as yet, no estimate of how many women are actually raped in South Africa each year.

$42 \mathrm{H}$ Moffet 'Feminism and the South African polity' in P Vale; L Hamilton and EH Prinsloo (eds) Intellectual traditions in South Africa. Ideas, individuals and institutions (2014) 234.

43 Moffett (n 42) 220.

$44 \mathrm{~K}$ Van Marle 'The capabilities approach, the imaginary domain, and asymmetrical reciprocity: feminist perspectives on equality and justice' (2003) 11 Feminist Legal Studies at 256. 
and values and develop a critical jurisprudence. As Peter Vale declares, 'it is only by rethinking the ideas that made us can we reimagine the world. ${ }^{45}$ A critical jurisprudence is one that is conscious of the historical injustices against the subaltern classes of Africans, women and the poor. It is jurisprudence that hears and acknowledges their plight and listens to their knowledge and voices. My argument is that the legal practice and adjudication can be made to be more cognisant of different perspectives offered by different legal theories. The assertion that the development of a critical jurisprudence will never be a finished work should not negate efforts directed at its development. 